\title{
SISTEMAS AGROFLORESTAIS DIRIGIDOS PELA SUCESSÃO NATURAL: UM ESTUDO DE CASO
}

\author{
FABIANA MONGELI PENEIREIRO \\ Engenheira Agrônoma
}

Orientador: Prof. Dr. RICARDO RIBEIRO RODRIGUES

Co-orientador: ERNST GÖTSCH

\begin{abstract}
Dissertação apresentada à Escola Superior de Agricultura "Luiz de Queiroz", Universidade de São Paulo, para obtenção do título de Mestre em Ciências, Área de Concentração: Ciências Florestais.
\end{abstract}

\footnotetext{
PIRACICABA

Estado de São Paulo - Brasil

Junho - 1999
} 
Dados Internacionais de Catalogação na Publicação (CIP) DIVISĀO DE BIBLIOTECA E DOCUMENTAÇĀO - Campus "Luiz de Queiroz"/USP

Peneireiro, Fabiana Mongeli

Sistemas agroflorestais dirigidos pela sucessão natural: um estudo de caso / Fabiana Mongeli Peneireiro. - Piracicaba, 1999.

138 p. : il.

Dissertação (mestrado) - Escola Superior de Agricultura Luiz de Queiroz, 1999. Bibliografia.

1. Degradação do solo 2. Ecologia florestal 3. Recuperação do solo 4. Sistema agroflorestal 5. Sucessão florestal I. Titulo

CDD 634.99

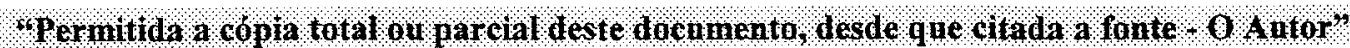




\section{SISTEMAS AGROFLORESTAIS DIRIGIDOS PELA SUCESSÃO NATURAL: UM ESTUDO DE CASO}

FABIANA MONGELI PENEIREIRO

Aprovada em: 05/08/1999

Comissão julgadora:

Prof. Dr. Ricardo Ribeiro Rodrigues

ESALQ/USP

Prof. Dr. Paulo Yoshio Kageyama

ESALQ/USP

Prof. Dr. Rodrigo Matta Machado

ICB/UFMG

Prof. RICARDO RIBEIRO RODRIGUES

Orientador 
"o mistério da vida me causa a mais forte emoção, é o sentimento que suscita a beleza e a verdade, cria a arte e a ciência. Se alguém não conhece esta sensação ou não pode mais experimentar espanto ou surpresa, já é um morto-vivo e seus olhos se cegaram".

\section{ALBERT EINSTEIN}

Dedico esta obra aos filhos da Terra. Àqueles que respeitam a vida, deixo aqui transparente minha alegria e incentivo, e àqueles que, cegos, destróem, minha aflição e desassossego. Que esta obra possa ser minha contribuição para um mundo melhor, com mais abundância em vida. 


\section{Agradecimentos}

Durante todo o percurso da caminhada de busca, no processo de criação deste trabalho, onde o caminho se fazia a cada passo, senti que tudo conspirava a favor de sua realização, pois sempre encontrei pessoas dispostas a ajudar, com grande generosidade, dando-me muito apoio e presenteando-me com amizade verdadeira, sem o que esta investida seria impossivel. Assim, por ser etemamente grata, exprimo aqui meus sinceros agradecimentos e alegria por poder ter tido a ventura encontrar pessoas verdadeiramente dispostas a ajudar, contribuir e incentivar. Sedimentou em mim a tranqüilidade de poder acreditar nas pessoas e num sonho comum.

Ao meu amigo Mario Eduardo Fraga da Silva, pela dedicação, companheirismo e ajuda, sem o que a coleta de dados e o tempo de permanência no campo seriam impossíveis e insuportável.

Ao meu querido orientador e amigo, Ricardo R. Rodrigues, que confiou em meu potencial e me deu asas para criar, acreditando na proposta e dando-me o apoio incontestável, contribuindo com certeiras guiadas. Também agradeço a ele (e a outros especialistas que também contribuíram) pela identificação botânica. Também agradeço aos meus amigos Paulo Henrique Cameiro (PC) e André Nave, pela ajuda na sistematização dos dados sobre vegetação.

Ao meu caro amigo e mestre Paulo Kageyama, que contribuiu com ricas idéias, apoiando-me no trabalho e incentivando-me.

A Ernst Götsch, co-orientador neste trabalho, exemplo de garra, disposição, e essencialmente o mentor-filósofo-agricultor-pesquisador do caso estudado, pelo carinho, dedicação e generosidade em apresentar suas idéias, mostrar seu trabalho, discutir, rever, disponibilizar seu conhecimento e seu material escrito, fruto de anos de trabalho; e também pela hospitalidade de toda sua familia, à querida amiga Renate, sua esposa, pelo carinho, simpatia e coração aberto.

À Gudrum, pelas escaladas nas árvores, em busca dos ramos para identificação das plantas, onde o podão não alcançava; e sua companhia.

Aos meus amigos de Ilhéus Max Menezes e Waléria, pela hospitalidade, confiança, alegria e braços abertos. Também à Cacau, uma referência para mim em Ilhéus, pela troca de idéias sobre o solo e a escolha das áreas, pela disposição em ajudar.

Aos colegas da CEPLAC que de alguma forma contribuíram com este trabalho, e especialmente ao Sandoval, ao pessoal do herbário (André, Jomar Jardim); ao Jafa, que nos apresentou a região.

À Maria Elizabeth Fernandes Correia - pesquisadora EMBRAPA - RJ - Agrobiologia, que contribuiu com a identificação da fauna do solo; a Patrick Lavelle, prof. na Universidade de Paris, e José Maria Ferraz - EMBRAPA - Jaguariúna, que mostraram-se prontos em contribuir com idéias e sugestões.

Ao prof. Gerd Sparovek, pelas dicas e disposição em contribuir com relação à identificação e dados de solos e ao Prof. Jairo Mazza, pela gentileza da revisão do Capítulo IV.

Aos meus queridos amigos de mesma empreitada, bandeirantes do mesmo caminho, o pessoal dos mutirões agroflorestais e, especialmente, às minhas queridas amigas Denise B. Amador (Potô) e Patrícia Vaz (Paty), que me deram a alegria de seu brilho, energia e amizade.

Ao Depto. de Ciências Florestais, que contribuiu financeiramente, de forma a viabilizar as análises laboratoriais.

Ao seu Bobô, o mateiro, símbolo do conhecimento do nosso povo, tão valioso e desvalorizado, pela disponibilização de seu conhecimento e ajuda em abrir as picadas e reconhecimento das plantas nativas.

À Marisol, pela preciosa colaboração e apoio.

Aos meus queridos amigos do grupo SAF, jovens que buscam novos caminhos para a agricultura, por terem me dado a oportunidade de espaço e nicho para discussão e troca de idéias, manifesto aqui o meu orgulho e a certeza de que a eles podemos confiar um futuro melhor.

Aos meus familiares queridos e amigos, às minhas irmãs, da Gaiola, que sempre me apoiaram e criaram ambiente propício para sempre me sentir bem; e a todos aqueles que (sem dúvida citar todos seria impossivel) contribuíram de uma forma ou de outra para a concretização desta dissertação, minha explícita gratidão.

Esta dissertação pode ser considerada uma conquista de todas estas pessoas, que entraram na história e vida deste trabalho, e que contribuiram para a disponibilização de reflexões e informações em busca de uma relação mais harmônica com Gaia. 


\title{
SISTEMAS AGROFLORESTAIS DIRIGIDOS PELA SUCESSÃO NATURAL: UM ESTUDO DE CASO
}

\author{
Autora: FABIANA MONGELI PENEIREIRO \\ Orientador: Prof. Dr. RICARDO RIBEIRO RODRIGUES \\ Co-orientador: ERNST GÖTSCH
}

\section{RESUMO}

Um sistema agroflorestal (SAF) orientado pela sucessão natural, na região de Floresta Ombrófila Densa Sub-montana, no sul da Bahia, Brasil, foi testado e discutido como uma estratégia de recuperação de solos degradados e também como um sistema de produção sustentável com grande potencial para substituir o modelo agrícola atual, que tem se apresentado muito impactante ambientalmente, socialmente e culturalmente.

Neste trabalho realizou-se uma comparação entre uma área de SAF com 12 anos de manejo (A12) e uma área em pousio (A0) de mesma idade, histórico e características ambientais, para identificar os efeitos do manejo de um SAF dirigido pela sucessão nos parâmetros vegetacionais (florística, fitossociologia e sucessão) e edáficos (serapilheira, solo e macrofauna edáfica).

Foi realizado o levantamento florístico e fitossiológico em duas áreas de 0,5 ha cada (denominadas A12 - SAF e A0 - Capoeira), as quais foram subdivididas em parcelas de $20 \mathrm{~m} \times 10 \mathrm{~m}$ e $35 \mathrm{~m} \times 14,3 \mathrm{~m}$, respectivamente, para identificação dos parâmetros vegetacionais comumente empregados nesses trabalhos. A similaridade florística entre as áreas estudadas foi verificada através do índice de Jaccard, cuja matriz foi usada em análises de classificação e ordenação.

Foram levantados também dados relativos à análise química do solo e da serapilheira, para as duas situações comparadas (SAF e Capoeira). A macrofauna presente na serapilheira e nos primeiros $5 \mathrm{~cm}$ de solo também foi coletada. O solo foi analisado a partir de 25 amostras compostas, para as três profundidades $(0-5,5-20$ e 40$60 \mathrm{~cm})$ e a serapilheira foi amostrada nos mesmos pontos, coletando-se o material de $0,25 \mathrm{~m}^{2}$ por ponto.

A vegetação das duas áreas estudadas A0 - Capoeira e A12 - SAF mostraram-se distintas tanto floristicamente como na estrutura fitossociológica. A composição florística mostrou que a área de SAF (A12) era mais avançada sucessionalmente que a de Capoeira, com destaque em densidade das famílias Mimosaceae, Lauraceae e 
Caesalpiniaceae. Na área de Capoeira (A0) a família de maior destaque em densidade foi a Melastomataceae. A área A12 (SAF) apresentou maior diversidade e eqüabilidade que a A0 (Capoeira).

A análise química do solo foi diferente entre as áreas, com destaque ao fósforo, que na área A12 apresentou aproximadamente 7 vezes mais $\mathrm{P} 2 \mathrm{O} 5$ na profundidade de 0 $-5 \mathrm{~cm}$ que a área $\mathrm{A} 0$ e de 4 vezes mais para $5-20 \mathrm{~cm}$. A área $\mathrm{A} 12$ apresentou $\mathrm{V} \%$ de $83 \%$ enquanto que a $\mathrm{A} 0$ apresentou $41 \%$, na profundidade de $0-5 \mathrm{~cm}$. Quanto aos resultados relativos à serapilheira, apesar do peso seco do folhedo não ter apresentado diferença estatística para as duas áreas, quimicamente a área Al2 mostrou teores de nutrientes na serapilheira muito superiores se aos da área $\mathrm{A}$, exceto para o cálcio e enxofre, que foram semelhantes. A macrofauna edáfica das duas áreas também foi diferente, sendo que a área A12 apresentou-se sucessionalmente mais avançada, com predominância de saprófitas, enquanto que na Capoeira houve predomínio de predadores.

$\mathrm{O}$ manejo da vegetação, com destaque às podas regulares, foi apontado como sendo o grande responsável pelas diferenças entre as áreas $\mathrm{A} 0$ e $\mathrm{A} 12$, conđuzindo a área manejada para uma condição sucessional mais avançada, com maior oferta de matéria orgânica com maior concentração de nutrientes, condicionando dinamização da ciclagem de nutrientes e da vida no sistema.

Constatou-se que o SAF em questão transformou área de solo distrófico em uma área produtiva, com alta fertilidade, em 12 anos de manejo, mostrando-se como uma altemativa promissora para a recuperação de solos degradados, além de se constituir num sistema de produção sustentável para os trópicos úmidos, sem a utilização de insumos extemos. 


\title{
AGROFORESTRY SYSTEMS DRIVED BY THE NATURAL SUCCESSION: A STUDY OF CASE
}

\author{
Author: FABIANA MONGELI PENEIREIRO \\ Adviser: Prof. Dr. RICARDO RIBEIRO RODRIGUES \\ Co-adviser: ERNST GÖTSCH
}

\section{SUMMARY}

An agroforestry system (SAF) conducted by the natural succession, on Rainforest Region, in South of Bahia, Brazil, was tested and discussed as a strategy for degraded soil recovery and also by a sustentable production system with a large potential to substitute the present agricultural pattern, which it has showed very environmentally, socially and culturally impacting.

In this paper, a comparison was made between an agroforestry area (A12 - SAF) and an area in fallow (A0 - Capoeira) to identify the effects of the management of an agroforestry system conducted by the natural sucession on vegetational (floristic, phytossociologic and succession) and edaphic (litter, soil and edaphic macrofauna) parameters. Twelve years ago both areas used to be fallows with the same historical use, at that time one of them got distinct treatment: one became an agroforestry while the other continued the natural regeneration process; beside that, being the areas contiguas they have the same environmental features (the same soil, the same topographical position, the same disturbs, etc.).

It was carried out the floristic and phytossociologic survey to identification of the vegetational parameters in the two areas of 0.5 ha each (termed A12 - SAF e A0 Capoeira), which were subdivided in plots of $20 \mathrm{~m} \times 10 \mathrm{~m}$ and $35 \mathrm{~m} \times 14.3 \mathrm{~m}$, respectively. This procedure is generally used in vegetational parameters studies. The similarity floristic between the studied areas was verified through the Jaccard index, whose matrix was used in classification and ordination analysis.

It was also made chemical analysis of the soil and the litter, for the two compared situations (SAF and Capoeira). The samples of macrofauna in the litter and in the first 5 $\mathrm{cm}$ of the soil were collected as well. The soil was analysed from 25 compound samples for the three depths $(0-5,5-20$ and $40-60 \mathrm{~cm})$ and the litter was sampled from $0.25 \mathrm{~m}^{2}$ in the points where the soil sampling was carried out. 
The vegetation of the two studied areas (A0 - Capoeira and A12 - SAF) showed distinct floristically as far as phytossociological structure. The floristic composition showed that the area of agroforestry (A12) was successionaly more advanced than the fallow (A0), with highlightness for the density of the families Mimosaceae, Lauraceae e Caesalpiniaceae. In the A0 (Capoeira), the family that had the largest density was Melastomataceae. The area A12 (SAF) lodged more diversity and equability than the A0 (Capoeira).

The results of soil's chemical analysis was different between the areas, with an outstanding to phosphorus, which in the area A12 having approximately seven times more $\mathrm{P}_{2} \mathrm{O}_{5}$ contents in the depth of $0-5 \mathrm{~cm}$, than the area $\mathrm{A} 0$ and 4 times more in the 5 $-20 \mathrm{~cm}$. The area $\mathrm{A} 12$ presented $\mathrm{V} \%$ of $83 \%$ while the A0 presented $41 \%$, in the depth of $0-5 \mathrm{~cm}$.

The litter's dry weight didn't show any statistical difference between the two areas. Despite that, chemically the area A12 showed drifts of nutrients in the litter upper when compered with the area in fallow, except to the calcium and sulphur, that were similar. The edaphic macrofauna of the two areas came out differently, since the area A12 presented successionaly to be more advanced, with predominance of saprophytics, while in Capoeira there was predominance of predators.

The management of the vegetacion, principally the regular pruning, was aimed to be the great responsible for the differences between the areas A0 and A12. The intervations realized in the area A12 conducted it to a successioanl advance through a high offer of organic matter with more concentration of nutrients, conditioning dinamization of nutrients cycling and the ecosystem's life.

It was concluded that the agroforestry system in question, in a period of 12 years, changed areas with dystrophic soils in productive areas, with high fertility, maintaining the biodiversity. This suggests that the agroforestry conducted by the natural succession is a promising alternative to reclaim degraded soils as well as to consist in a sustentable production system without the necessity of external inputs. 


\section{SUMÁRIO}

Página

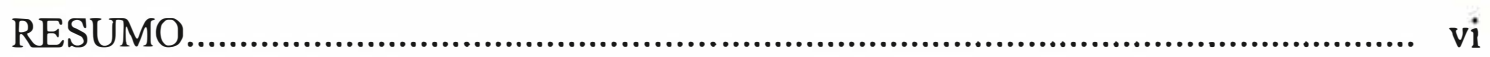

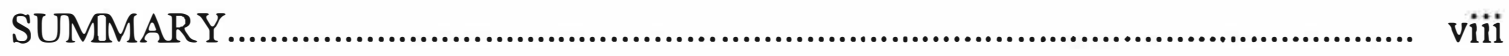

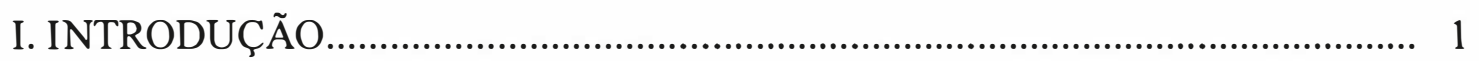

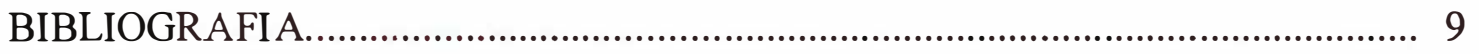

II. DELINEAMENTO METODOLÓGICO E CONDIÇÕES PARA VALIDAÇÃO

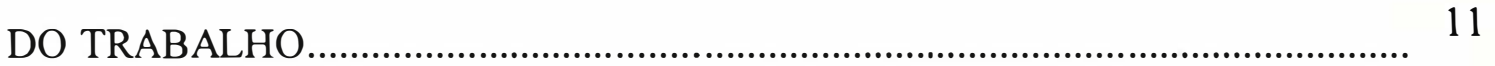

II.1. CARACTERIZAÇÃO DA ÁREA DE ESTUDO......................................... 11

II.1.1. Caracterização regional........................................................................ 11

II.1.2. Caracterização da propriedade agrícola "Três Colinas", onde foram instalados os tratamentos.

II.1.2.1. Escolha das áreas de estudo................................................. 14

II.1.2.2. Requisitos para escolha das áreas.......................................... 16

II.1.2.2.1. Fatores fĩsicos......................................................... 16

II.1 2.2.2. Histórico das áreas................................................. 16

II. 1.3. Alocação das parcelas.................................................... 19

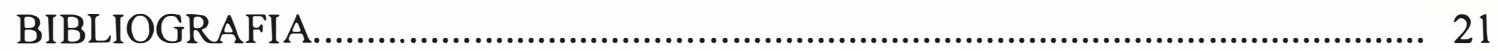

III. AS ALTERAÇÕES DOS PARÂMETROS VEGETACIONAIS NUM SISTEMA AGROFLORESTAL DIRIGIDO PELA SUCESSÃO

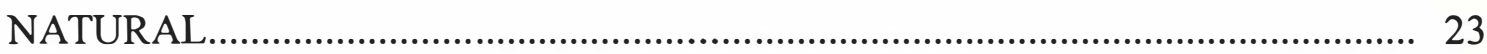

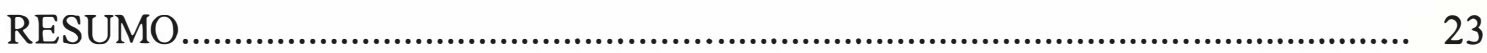

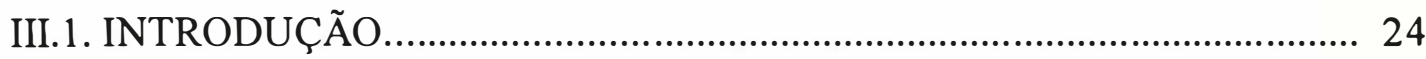

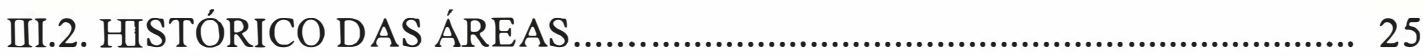

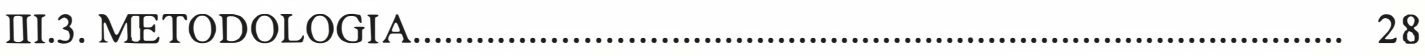

III.4. RESULTADOS E DISCUSSÃO_........................................................ 29

III.5. CONCLUSÃO............................................................................... 40

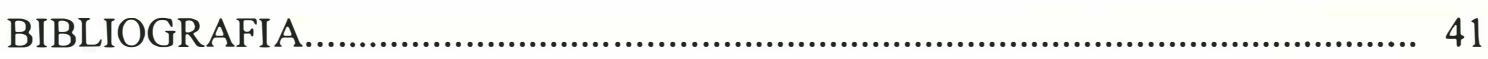

IV. AS ALTERAÇÕES DOS PARÂMETROS EDÁFICOS NUM SISTEMA 
AGROFLORESTAL DIRIGIDO PELA SUCESSÃO

NATURAL

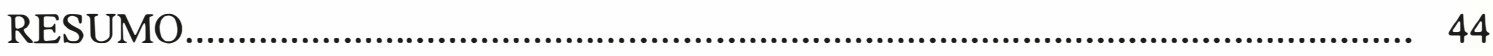

IV.1. INTRODUÇÃO........................................................................... 45

IV.2. CARACTERIZAÇÃO DAS ÁREAS DE ESTUDO................................. 49

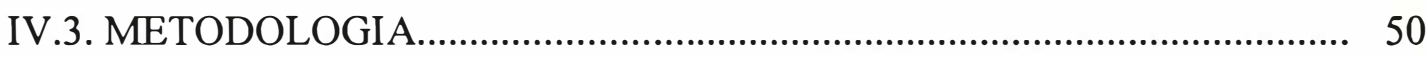

IV.4. RESULTADOS E DISCUSSÃO........................................................... 52

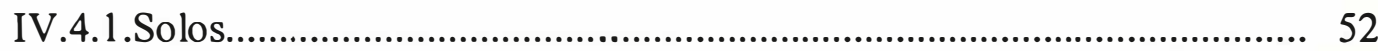

IV.4.2. Macrofauna edáfica........................................................................ 59

IV.4.3. Serapilheira..................................................................................... 63

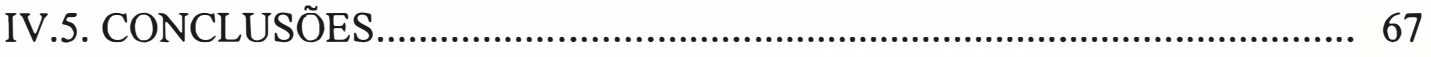

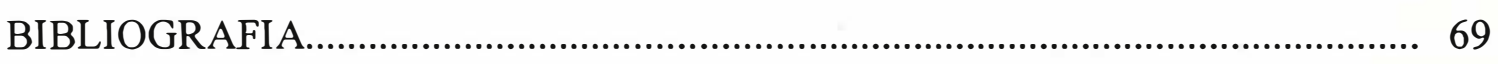

V. A PROPOSTA DE ERNST GÖTSCH PARA SISTEMA AGROFLORESTAL DIRIGIDO PELA SUCESSÃO NATURAL: ASPECTOS FILOSÓFICOS, CONCEITUAIS E PRÁTICAS DE MANEJO...... 73

V.1. O fundamento filosófico............................................................................ 73

V.2. Conceitos fundamentais que alicerçam o sistema Agroflorestal dirigido pela Sucessão Natural.

V.3. As práticas de manejo nos SAFs dirigidos pela sucessão natural na Mata Atlântica...

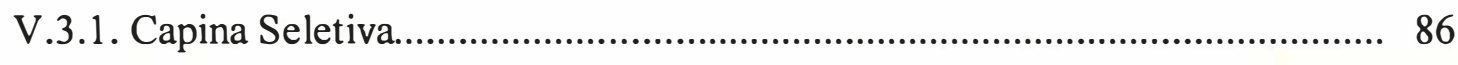

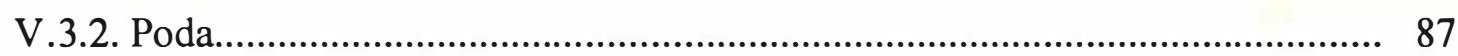

V.3.3. Consórcios / Alta densidade de plantio / Plantas estratégicas...................... 89

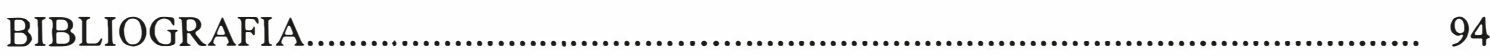

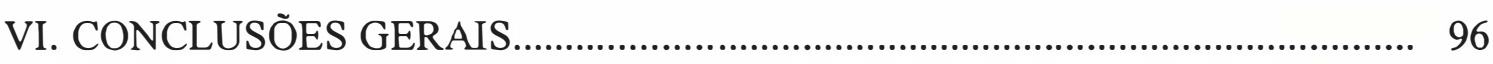

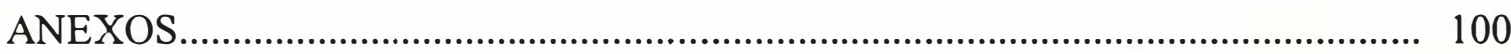




\section{INTRODUÇÃO}

A crise ambiental, refletida diretamente na agricultura, é fruto dos sérios problemas ambientais acarretados pela Revolução Verde ${ }^{1}$, como degradação e ameaça de escassez dos recursos naturais, contaminação dos mesmos e do ser humano, baixa eficiência energética, etc. (Ehlers, 1996). Atualmente a agricultura moderna vai além desse pacote tecnológico acima citado, ao incluir as sementes "bio-engenheiradas", ressaltando ainda mais a dependência do agricultor pelos insumos acoplados (Almudena, 1998).

A maioria das pesquisas científicas da agricultura moderna, coerente com o paradigma dominante, tem sido dirigida para maximizar a produção, ao invés de otimizá-la, e para solucionar problemas de produção mais imediatos do que a resiliência ou sustentabilidade dos sistemas agrícolas. Tem-se enfocado apenas parte dos componentes do sistema agrícola ao invés do sistema como um todo e a avaliação dos seus resultados tem sido baseada primeiramente no retorno econômico a curto prazo e não na sustentabilidade do sistema a longo prazo. O resultado desta abordagem tem sido o desenvolvimento de uma super-produção, através de uma agricultura industrial que apresenta grande dificuldade de manter a qualidade ambiental, os recursos naturais, a segurança alimentar e a qualidade de vida rural (Gliessman, 1990).

A agricultura moderna está evidentemente baseada no industrialismo. É notável a simplificação dos sistemas agrícolas, onde os meios de produção podem ser simplificados à terra (tida mais como suporte), os insumos e a mecanização, que é viabilizada pelas grandes áreas de cultivos extensos e homogêneos. $\mathrm{Na}$ grande "indústria" da produção de alimento, entra-se com sementes melhoradas por um lado do

${ }^{1}$ Denomina-se Revolução Verde o processo pelo qual o padrão agrícola químico, motomecânico e genético, gestado nos EUA e na Europa, que foi disseminado para várias partes do planeta. Este termo deriva dos enormes avanços da genética que, aplicada à agricultura, possibilitou a produção de variedades vegetais altamente produtivas, desde que se utilizasse também um conjunto de práticas e de insumos que ficou conhecido como "pacote tecnológico" (Ehlers, 1996). 
sistema e retira-se o produto agrícola desejado pelo outro, seguindo receitas bem ajustadas. O que acontece é que este sistema apresenta gargalos inesperados como pragas e doenças resistentes aos agrotóxicos, compactação do solo, salinização, conflitos sociais, variações climáticas, perda da biodiversidade, etc., além de um balanço energético extremamente desfavorável, que se define no custo de produção. Isto é um sinal de que, ao lidar com agricultura, o homem lida com sistemas vivos, onde complexas interações ocorrem e as respostas à simplificação, se não são imediatas, são certas (Ehlers, 1996; Graziano Neto, 1991; Campos, 1991).

A partir de todo este contexto agrícola paira uma discussão generalizada sobre o tema sustentabilidade, que pode se caracterizar ora como sendo superficial, como retórica política, ora profunda, envolvendo debates a respeito de ética, atitudes, paradigmas. Para muitos, sustentabilidade é uma palavra já despida de significado, fruto do uso exagerado pelo "modismo", já que muitos usam a palavra por estar na "ordem do dia", por ser "politicamente correto", e também, por apresentar um significado abrangente, por ser carregada de conceitos complexos e paradoxais, que podem refletir diferentes interesses - , que fez com que o termo fosse perdendo a sua objetividade.

O conceito sustentável, que pode ser aplicado para desenvolvimento e mais especificamente para agricultura, aceita uma vasta gama de definições, que se ajustam a diferentes interesses e filosofias, não apresentando um consenso. Há uma discussão mundial, a respeito deste assunto, entre o setor industrial economicamente dominante da sociedade e o movimento ambientalista, desde o surgimento deste conceito. $\mathrm{O}$ tema sustentabilidade surgiu como novo "paradigma" das sociedades modernas, em meados dos anos 80 , com a crescente preocupação com o ambiente e com a qualidade de vida no planeta (Ehlers, 1996).

A agricultura sustentável é um anseio mundial, já que o ser humano depende diretamente da produção de alimentos e matérias primas a partir da atividade agrícola. Hoje, o atual modelo de produção agrícola, conhecido como agricultura convencional ${ }^{2}$, vive um período de crise, já que a agricultura mostra-se como uma atividade altamente

\footnotetext{
${ }^{2}$ A agricultura convencional foi definida como "agricultura de fertilizantes artificiais, herbicidas e pesticidas, além de intensiva produção animal"(Knorr e Watkins 1984:x, apud Ehlers, 1996).
} 
insustentável, degradante do meio e dependente de altos "inputs" energéticos, de insumos externos, com custos elevados e sérios reflexos sociais ocasionados pelo êxodo rural.

São evidentes duas linhas de pensamento muito distintas para a agricultura sustentável, na verdade, com perspectivas dramaticamente divergentes: uma que acredita que o atual rumo de desenvolvimento é desejável e que é possível atingirmos a sustentabilidade fazendo apenas alguns ajustes no atual sistema produtivo, usando a tecnologia com maior eficiência e "racionalidade"; a outra é incisivamente a favor de mudanças radicais no atual modelo de desenvolvimento e tecnológico, e discute uma mudança do paradigma atual, sem a qual a sustentabilidade nunca deixará de ser uma utopia. Para este segmento, a agricultura sustentável é vista como uma possibilidade de ' se promover transformações sociais, econômicas e ambientais em todo sistema agroalimentar, passando pelas pesquisas na área agrícola e social, pelos hábitos de consumo alimentar ou pela revisão das relações entre os países desenvolvidos e os não desenvolvidos. São transformações que levam em conta a democratização do uso da terra, a erradicação da fome e da miséria e a promoção de melhorias na qualidade de vida de centenas e milhões de habitantes (Ehlers, 1996; Beus \& Dunlap, 1991).

Para se desenvolver uma agricultura que seja sustentável ambientalmente é preciso assumir que lidar com agricultura é lidar com vida e que o paradigma do industrialismo presente hoje em nossa sociedade que inclusive direciona o fazer agricultura nos moldes modernos, pressupondo monocultura em grandes áreas, mecanização, uso de espécies melhoradas, de insumos externos em larga escala, etc., deve ser superado, pois é incompatível com as leis que regem os sistemas vivos, com seus ritmos e comportamentos próprios (Ehlers, 1996; Campos, 1991).

Mesmo a despeito das dificuldades em se apontar uma definição consensual para "agricultura sustentável", já é possível prever algumas características básicas desse padrão: a conservação dos recursos naturais, como o solo, a água e a biodiversidade; a diversificação; a rotação de culturas e a integração da produção animal e vegetal; a valorização dos processos biológicos; a economia de insumos; o cuidado com a saúde dos agricultores e consumidores e a produção de alimentos com elevada qualidade 
nutritiva e em quantidades suficientes para atender a demanda global (Ehlers, 1996). No entanto, segundo Ehlers (1996), “as práticas que levarão a estes objetivos não se constituirão como um conjunto bem definido, como foi o chamado "pacote tecnológico" da Revolução Verde, pois cada agroecossistema apresenta características próprias e requer práticas e manejos específicos", embora os princípios, fundamentos e conceitos básicos devam ser únicos ${ }^{3}$ e servir para quaisquer situação. De acordo com Ehlers (1996), “a agricultura sustentável combinará, provavelmente, princípios e práticas da agricultura alternativa e da convencional, assim como novos conhecimentos que surgirão tanto da experiência proveniente dos agricultores como da pesquisa científica, especialmente no campo da agroecologia (disciplina científica que estuda os agroecossistemas)".

As atuais soluções teoricamente sustentáveis não são facilmente multiplicáveis. São bem específicas de um determinado ecossistema e muito exigentes em conhecimento agroecológico, além de pouco competitivas, tanto do ponto de vista econômico, como do ponto de vista político (Ehlers, 1996). Nada impede que essa situação venha a se alterar sob as pressões sociais por alimentos saudáveis e respeito à natureza. "Estamos no início de uma longa transição agroambiental e não de uma fase de mudanças aceleradas que caracterizam as revoluções" (Ehlers, 1996).

Götsch ${ }^{3}$. buscando exatidão para o termo sustentável, define: "uma intervenção é sustentável se o balanço de energia complexificada e de vida é positivo, tanto no subsistema em que essa intervenção foi realizada quanto no sistema inteiro, isto é, no macroorganismo planeta Terra). Sustentablidade mesmo só será alcançada quando tivermos agroecossistemas parecidos na sua forma, estrutura e dinâmica ao ecossistema natural e original do lugar da intervenção e quando se fizer agricultura sem o uso de máquinas pesadas, sem adubos trazidos de fora do sistema e sem agrotóxicos".

Ao se discutir sistemas agrícolas sob uma abordagem agroecológica ${ }^{4}$, de forma sistêmica, reconhece-se que existem muitas variáveis dependentes e interrelacionadas,

${ }^{3}$ GÖTSCH, E. Comunicação pessoal, 1998.

${ }^{4}$ A agroecologia busca, a partir da observação dos ecossistemas naturais, do resgate do conhecimento tradicional e no conhecimento científico multidisciplinar, ferramentas para se avançar rumo à 
reforçando a necessidade de se levar em consideração todo o contexto que envolve a questão da sustentabilidade na agricultura.

Os sistemas agroflorestais (SAFs) conduzidos sob uma lógica agroecológica transcende qualquer modelo pronto e sugere sustentabilidade por partir de conceitos básicos fundamentais, aproveitando os conhecimentos locais e desenhando sistemas adaptados para o potencial natural do lugar (Götsch, 1995).

SAFs sustentáveis sempre foram e continuam sendo desenvolvidos por muitos povos indígenas ou populações autóctones em todo o mundo, cujos princípios estão intrinsecamente arraigados às culturas milenares que foram se adaptando ao meio e este se moldando à ação humana.

$\mathrm{O}$ resgate cultural e do conhecimento local (adquiridos pelas pessoas do lugar, através da vivência das gerações, fruto de séculos de convívio com o ecossistema local) é de extremo valor e importância para a elaboração de sistemas de produção sustentáveis (Altieri, 1983; Anderson (1980) apud Lima, 1994; Firebaugh, 1990).

Os sistemas de produção sustentáveis, ao que tudo indica, deverão ser mais dependentes de conhecimento científico, ecológico, e local, além de assumir perspectivas interdisciplinares (Ehlers, 1996), e não um retrocesso, como muitos podem pensar, pela diminuição da dependência por recursos externos. A tecnologia será essencialmente atrelada ao conhecimento da vida e sua dinâmica, ou seja, uma "tecnologia soft, sensível" e não necessariamente dependente de máquinas pesadas ou insumos químicos mais elaborados.

Nas áreas tropicais, a agrofloresta, ou sistemas agroflorestais, pode ser uma opção interessante para a busca da sustentabilidade na agricultura, uma vez que apresenta elementos que propiciam aliar a produção à conservação dos recursos naturais.

sustentabilidade de qualquer prática humana sobre os recursos naturais. Sugere-se que, se nos inspirarmos nus processos de vida da natureza para conduzir os sistemas antropogênicos, será possivel a aquisição de recursos concomitantemente com a manutenção ou até restauração dos recursos naturais. Ilustraremos esta idéia com a citação de REINTYJES (1994): "Os agroecologistas reconhecem, hoje, que a consorciação, a agrossilvicultura e outros métodos tradicionais de agricultura imitam os processos ecológicos naturais e que a sustentabilidade de muitas práticas locais deriva dos modelos ecológicos que elas seguem. Ao se planejarem sistemas agrícolas que imitam a natureza, torna-se possível otimizar o uso da luz do sol, dos nutrientes do solo e da chuva." 
“Agrofloresta é uma palavra nova para práticas antigas onde plantas lenhosas crescem com cultivos agrícolas e/ou gado na mesma unidade de área"s. Apesar do conceito de agrofloresta mais conhecido ou divulgado, elaborado pelo ICRAF ("SAF são combinações do elemento arbóreo com herbáceas e/ou animais organizados no espaço e/ou no tempo"6), contemplar a maioria dos sistemas agroflorestais, pelo seu caráter genérico, os SAFs complexos (biodiversos) pouco se assemelham com os consórcios cartesianos usados nos SAFs mais tecnificados, ou elaborados com conhecimento técnico puramente agronômico. O salto de qualidade entre os SAFs consórcios e os SAFs biodiversos está justamente na mudança de paradigma ao lidar com a natureza para elaborar uma proposta de SAF.

Assim, mais que apresentar um sistema de produção, com desenho de consórcios, regras e conselhos de manejo, a abordagem deste trabalho trata de repensar a postura do homem frente ao ambiente que o cerca e apontar conceitos fundamentais e propostas metodológicas que possibilitem. a elaboração dos SAFs sustentáveis. "O produto final necessário a uma agricultura ecológica é um ser humano desenvolvido e consciente, com atitudes de coexistência e não de exploração para com a natureza" (Altieri, 1983, P. 211).

Ao concordar com Combe (1982), quando pensa que "antes de novas técnicas agroflorestais serem difundidas, é importante empreender estudos de caso de aplicações de sucesso existentes" e também com Sheldrake (1996), ao introduzir a idéia de que "o conhecimento adquirido por meio da experiência com plantas e animais não é um substituto inferior de um conhecimento científico mais exato: pelo contrário, é a própria coisa real", reforça-se a importância de se desenvolver este estudo de caso e de se valorizar também os conhecimentos empíricos e as evidências qualitativas. "Pesquisa em agrofloresta sempre tem um caráter interdisciplinar. A melhor abordagem é certamente suprida pela análise completa do agroecossistema" (Combe, 1982).

Dessa forma, o objetivo geral deste trabalho é apresentar um estudo de caso que trata de uma proposta de Sistemas Agroflorestais desenvolvidos no sul da Bahia (por

\footnotetext{
${ }^{5}$ Nỳhoff, 1982, p. 369

${ }^{6}$ Lundgren, 1982, p.4.
} 
Ernst Götsch), cujo método de implantação e manejo é baseado no processo de sucessão natural. Este caso foi escolhido por apresentar resultados interessantes no que diz respeito à recuperação de áreas degradadas, desenvolvimento de sistemas de produção agroflorestais sustentáveis, e processo de revegetação, sendo uma oportunidade ímpar de se tentar compreender cientificamente e divulgar um trabalho pioneiro que traz esperanças de sustentabilidade para a agricultura, tão almejada nesta presente década $\mathrm{e}$ para o século 21 que já desponta.

A hipótese deste trabalho é que o manejo agroflorestal utilizado acelera o processo sucessional e a recuperação das áreas degradadas. A fim de checar este pressuposto, nortearam o trabalho de campo as seguintes perguntas fundamentais: i) $\mathrm{O}$ manejo do SAF interfere na vegetação e no solo? ii) Como se dá essa interferência ou essa modificação nos atributos do ecossistema?

O objetivo específico do trabalho de campo foi comparar duas áreas (uma de $\mathrm{SAF}$, de 12 anos de manejo, e outra área abandonada, de mesma idade) quanto à vegetação, reservatório de nutrientes (solo e serapilheira) e macrofauna edáfica, na tentativa de compreender as inter-relações entre os compartimentos do sistema (vegetação, serapilheira, solo e macrofauna edáfica) à luz do conhecimento disponível, conforme ilustrado na Figura 1, realizando:

i) levantamento florístico e fitossociológico da vegetação nas duas áreas comparadas;

ii) estimativa das quantidades de detritos orgânicos na serapilheira dos teores de nutrientes estocados na serapilheira;

iii) análise química do solo e levantamento qualitativo da macrofauna edáfica das duas áreas comparadas. 


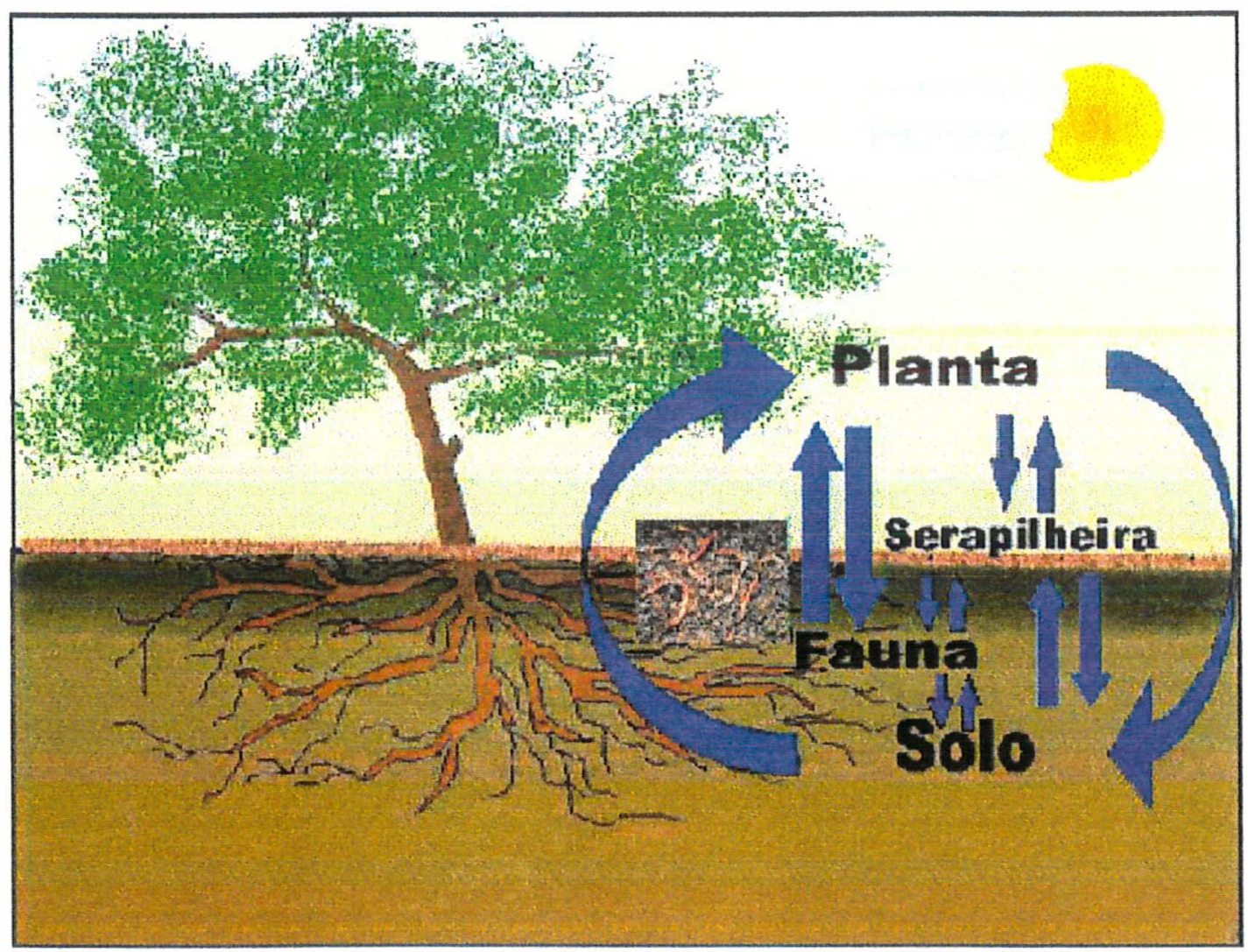

Figura 1 - Ilustração da abordagem sistêmica, envolvendo os quatro compartimentos do ecossistema estudado nesse trabalho, nas duas áreas (SAF e Capoeira), município de Ituberá, Bahia, Brasil. 


\section{BIBLIOGRAFIA}

ALMUDENA, C. O gene exterminador. Folha de S. Paulo (Caderno Folhamais!), São Paulo, 16/ago/98, caderno 5, p. 14.

ALTIERI, M. A. Agroecologia: as bases científicas da agricultura alternativa. Rio de Janeiro: AS-PTA, 1989. 235p.

BEUS, C.E.; DUNLAP, R.E. Conventional versus alternative agriculture: the paradigmatic roots of the debate. Rural Sociology,, v. 55, n. 4, p. 590-616, 1990.

CAMPOS, M. D’O. Fazer o Tempo e o Fazer do Tempo: ritmos em concorrência entre o ser humano e a natureza. Ciência e Ambiente, Ed. Educ. Ambiental, v. 8, p. 733, jan/jun, 1994.

COMBE, J. Técnicas agroflorestais em países tropicais: potenciais e limitações. Agroforestry Systems, v. 1, p. 13-27, 1982.

EHLERS, E. Agricultura Sustentável. Origens e perspectivas de um novo paradigma. São Paulo: Livros da Terra. 1996. 178p.

FIREBAUGH, F.M. Sustainable Agricultural Systems: a concluding view. In: EDWARDS, C. A.; LAL, R.; MADDEN, P.; MILLER, R.H.; HOUSE, G. Sustainable Agricultural Systems. Florida: St. Lucie Press (Soil and Water Conservation Society), 1990. Cap. 40. p. 696.

GLIESSMAN, S. R. Agroecology: Researching the ecological bases for sustainable agriculture. New York: Springer-Verlag, 1990. 380p.

GÖTSCH, E. Break-thropugh in agriculture. Rio de Janeiro: AS-PTA, 1995. 22p. 
GRAZIANO NETO, F. Questão agrária e ecologia: crítica da moderna agricultura. São Paulo: Ed. Brasiliense, 1991. 240p.

LUNDGREN, B. Introduction. Agroforestry Systems, v. 1, p. 3-6, 1982.

NŸHOFF, M. What is agroforestry? Agroforestry Systems, v. 1, p. 369, 1982.

SHELDRAKE, R. O Renascimento da Natureza. São Paulo: Ed. Cultrix, 1991. 236p. 


\section{DELINEAMENTO METODOLÓGICO E CONDIÇÕES PARA VALIDAÇÃO DO TRABALHO}

Para tentar responder às questões-chave formuladas neste trabalho, comparou-se duas áreas contíguas de mesma idade, uma manejada à 12 anos com sistemas agroflorestais (SAF) e outra não manejada de mesma idade, ocupada com capoeira, com as mesmas características na paisagem. Para validação deste artifício seria imprescindível que as duas áreas fossem comparáveis, ou seja, que tivessem as mesmas características vegetacionais de origem, mesmo histórico de ocupação antrópica (histórica e.atual), declividade semelhante, mesma posição no relevo; mesma face de exposição ao sol e mesmo tipo de solo.

Parte dessas semelhanças são resultantes do fato dessas áreas serem contíguas, mas a questão edáfica era imprescindível, já que o manejo interferia diretamente nas características do solo. Dessa forma foi estabelecida uma estratégia metodológica própria apresentada no ítem II.1.2.2.

\section{1. CARACTERIZAÇÃO DA ÁREA DE ESTUDO}

\section{1.1. Caracterização regional}

A área estudada está localizada no Sul do Estado da Bahia em região de Floresta Atlântica "sensu stricto" e vem sofrendo intenso desmatamento (Santana et al., 1990), seja pela retirada da vegetação original em sua íntegra, seja por sua intensa exploração madeireira ou mesmo abertura dessas áreas para a prática agrícola.

No início da colonização portuguesa, as florestas costeiras, conhecidas como Floresta Atlântica ou Mata Atlântica, estendiam-se na costa leste da América do Sul, prọlongando-se desde o Cabo de São Roque, no Rio Grande do Norte $\left(6^{\circ} \mathrm{S}\right)$ até a região 
de Osório, no Estado do Rio Grande do $\operatorname{Sul}\left(30^{\circ} \mathrm{S}\right)$, ocupando uma área aproximada de 1.000.000 $\mathrm{Km}^{2}$; interiorizavam-se cem quilômetros da costa no norte e alargavam-se a mais de quinhentos quilômetros no sul. A Mata Atlântica abrange três formações florestais distintas: matas de planície litorânea, matas de encosta e matas de altitude (Joly et al., 1991; Dean, 1996).

Além de ser considerada a formação vegetal brasileira mais antiga e com uma ampla extensão territorial, a Mata Atlântica é também reconhecida como a região de maior índice de endemismo e biodiversidade (Fonseca, 1985; Brown Jr., 1987; Mori, 1989; Peixoto, 1991/92; Dean, 1996), apresentando como centros prioritários dessas relações, trechos entre o Sul/Sudeste da Bahia, Nordeste do Espírito Santo, arredores do Rio de Janeiro e costa de Pernambuco.

Para se ter idéia da realidade atual desta exuberante formação florestal, no qüinqüênio de 1985 a 1990 , de que $5330 \mathrm{Km}^{2}$ haviam se perdido de florestas naturais, restando apenas $83.500 \mathrm{Km}^{2}$, um pouco mais de $8 \%$ da floresta que presumivelmente havia em 1500 (Dean, 1996; S.O.S. Mata Atlântica, 1993).

'No início dos anos 70, os últimos grandes maciços de árvores da Mata Atlântica se encontravam no sul da Bahia. Em 1971, cerca de $11 \mathrm{mil} \mathrm{Km}^{2}$ da floresta do sul da Bahia permaneciam intatos. No início dos anos 80, restavam menos de 2 mil $\mathrm{Km}^{2 "}$ (Dean, 1996). E o mesmo autor acrescenta que com a construção da rodovia federal BR101, a destruição da Mata Atlântica do sul da Bahia foi muito intensa e acelerada.

Enquanto isso, a lavoura cacaueira ia se instalando no sul da Bahia, conferindo a esta região, um histórico um pouco diferente das outras regiões, pois teve seu desmatamento retardado pela cultura do cacau, que era introduzido no sub-bosque das florestas nativas raleadas. Este sistema tradicional, conhecido como "cabruca", preservava provavelmente a metade das espécies originais da floresta e, por isso, passou a ser considerado pelos ambientalistas como preferível quando comparado à abertura de clareiras, para o plantio do cacau, insistentemente recomendada pela CEPLAC ou a substituição da floresta por atividades agropecuárias (Santana et al., 1990).

A condição florestal dessa região foi poupada por um pouco mais de tempo, somente porque a lavoura cacaueira dependia da sombra das espécies florestais. Uma 
vez que a pesquisa apresentou uma alternativa para a produção (a partir de 1965, dada a disponibilidade de germoplasma melhorado), implementou-se o método de derruba total da floresta para formação de plantações tecnicamente orientadas, empregando-se um espaçamento regular, normalmente $3 \times 3 \mathrm{~m}$, com sombreamento provisório de bananeira e um sombreamento definitivo constituído de 35 árvores de eritrina (Erythrina fusca ou E. poeppigiana) por hectare distribuídas em quincôncio (Santana et al., 1990), de forma independente da floresta. Esse método foi escolhido, com conseqüente supressão da floresta.

Com a baixa nos preços do cacau, e também com o declínio da cultura pela forte incidência da "vassoura de bruxa", a tendência atual da região tem sido a substituição da lavoura cacaueira por outras culturas mais rentáveis, ou então mesmo pastagens, acelerando sobremaneira a velocidade de desmatamento do pouco que resta da Mata Atlântica no Sul da Bahia.

O clima da região é quente e úmido, sendo que a pluviosidade média é de 1500 $\mathrm{mm}$ bem distribuídos no ano, apresentando uma leve estiagem no verão (dezembro a fevereiro) e uma maior concentração de chuvas no inverno (junho a agosto).

\section{1.2. Caracterização da propriedade agrícola "Três Colinas", onde foram instalados os tratamentos}

A propriedade Três Colinas, do agricultor-pesquisador Ernst Götsch, onde foi realizado este estudo de caso, está localizada na região sul da Bahia, entre as cidades de Gandu e Ituberá, na longitude $39^{\circ} 17^{\prime} 08^{\prime}$ 'W e latitude $13^{\circ} 44^{\prime} 45^{\prime}$ 'S, a uma altitude de $350 \mathrm{~m}$. O relevo local é fortemente ondulado, apresentando solos latossólicos e podzólicos argilosos com alto grau de intemperização, profundos, ricos em óxidos de ferro e alumínio, considerados pouco férteis, derivados de rochas gnaissicas e graníticas do planalto cristalino, do período Pré-Cambriano.

A paisagem do entorno da propriedade consiste em áreas de pastos, lavouras de cacau (algumas praticamente abandonadas), lavouras de mandioca e outras culturas de 
subsistência, além de capoeiras em diversos estágios de desenvolvimento. São também encontradas, nas proximidades, culturas tipicamente tropicais como dendê, seringueira, cravo, guaraná, e outras.

\section{1.2.1. Escolha das áreas de estudo}

A propriedade em questão tem 470 ha, sendo que 103 ha estão ocupados com a cultura do cacau. Ultimamente apenas 15 ha estão ocupados com SAFs que estão sendo manejados e utilizados para fins econômicos (onde o cacau é colhido e beneficiado, e também se produz banana e abacaxi, além de outras frutíferas e olerícolas para subsistência). O restante da área da propriedade (aproximadamente 450 ha) está reservada como área de preservação natural, em franco processo de regeneração, com matas primárias, secundárias e capoeiras altas.

Na Fazenda Três Colinas não existem mais áreas não manejadas que tenham histórico semelhante ao das áreas implantadas, pois toda área degradada, assim que Ernst se apossou da propriedade, foi destinada à recuperação com SAFs. Sendo assim, optou-se por escolher uma área de SAF produtiva, entre as mais antigas da propriedade (com 12 anos), a qual foi comparada com uma área de Capoeira, abandonada, contígua à área manejada, porém pertencente à propriedade vizinha à Três Colinas. A escolha das áreas foi muito cuidadosa, pois se fossem escolhidas áreas não comparáveis, o trabalho todo estaria comprometido.

Assim, para a escolha da área manejada, foram estabelecidos alguns requisitos como: que estivesse em produção; que fosse possível reconstituir o histórico de intervenção antrópica da área; que fosse uma das áreas mais antigas de SAF na propriedade e que no início de sua implantação apresentasse as mesmas características de vegetação e histórico de que uma área não manejada, a ser escolhida. Eram muitas as variáveis que deveriam ser coincidentes e, felizmente, após diversas tradagens de solo (de $20 \mathrm{em} 20 \mathrm{~cm}$ até $1 \mathrm{~m}$ de profundidade) de algumas áreas potenciais para o trabalho, a fim de se saber se tratava-se realmente de mesmo solo (ao serem avaliados textura, cor, 
estrutura e outros indicativos) e convergindo todas as informações a respeito dos prérequisitos relevantes citados acima, efetuou-se a escolha das áreas de estudo.

Depois de acurado processo de escolha, optou-se por uma área manejada, designada de A12 (ANEXO A) com mesmo histórico de exploração e uso anteriores de uma área em pousio, hoje uma Capoeira, designada de A0 (ANEXO B), com a qual se procedeu a comparação. O manejo da área de SAF (A12) foi iniciado há 12 anos, coincidindo com o período que a área comparada (A0) foi abandonada. Dessa forma, as áreas escolhidas tinham características semelhantes há 12 anos atrás, sendo que uma foi deixada abandonada e a outra foi objeto de manejo em SAF. As áreas são contíguas e ambas estão situadas próximas à estrada pública, apresentando mesmo tipo de solo, mesma posição no relevo, declive semelhante, mesma face de exposição ao sol, mesmo histórico inicial e mesmo grau de perturbação.

Atualmente pode-se identificar duas fisionomias bem distintas da vegetação presente nas duas áreas. A vegetação da área manejada de $\mathrm{SAF}$, hoje, difere imensamente da capoeira em regeneração natural, pois aquela apresenta, de maneira geral, estratos definidos de copa, com plantas de cacau no sub-bosque, e pouca vegetação herbácea (as presentes são basicamente mudas das arbóreas presentes e as gramíneas são praticamente ausentes). Já na área de capoeira (A0), há manchas de vegetação, podendo ser distinguidas quatro: capoeira baixa com feto-de-gaiola (onde o Pteridium prevalece, formando um "colchão" de até $3 \mathrm{~m}$, subindo nas árvores isoladas, dando a impressão de uma "vegetação amarrada", dificultando muito a caminhada pela área), capoeira baixa com sapé (vegetação onde é característica a disparidade entre os estratos herbáceo e arbóreo, o que facilita o deslocamento na área), capoeira de transição (são presentes as tiriricas-navalha, que sobem escorando-se nas árvores e cipós, formando um emaranhado fino e cortante) e capoeira alta com lianas (há presença de muitas árvores e arbustos finos em maior densidade, entrelaçados por cipós).

$\mathrm{Na}$ área de $\mathrm{SAF}$, praticamente caminha-se o tempo todo sob a sombra das árvores e sobre a espessa camada de serapilheira, sentindo um micro-clima quente e úmido. Na área de capoeira, em algumas manchas caminha-se sob o sol, e noutras é difícil caminhar, pois a vegetação entrelaçada não permite o trânsito livre. 


\section{1.2.2. Requisitos para escolha das áreas}

\section{1.2.2.1. Fatores físicos}

As duas áreas estão distantes de aproximadamente $800 \mathrm{~m}$ uma da outra, seguindo pela estrada, e tratam-se de meia-encostas situadas à mesma posição no relevo, sobre relevo ondulado, com fraco declive (variando de 5 a $20 \%$ ), voltadas para a mesma face de exposição (NE) e marginais à mesma estrada municipal, estando susceptíveis às mesmas perturbações (vento, fogo, efeito de borda).

Com o propósito de identificar o tipo de solo, em cada uma das duas áreas escolhidas abriu-se uma trincheira de 1,5 $\mathrm{m}$ de profundidade e ainda foram efetuadas tradagens até $2,40 \mathrm{~m}$. Realizou-se uma descrição morfológica do perfil e coletou-se amostras de solo de cada horizonte, encaminhando-as para análises físicas e químicas. A partir da avaliação morfológica dos perfis e dos dados dos horizontes, constatou-se que trata-se de mesmo solo para as duas áreas, fato que, junto com os outros requisitos coincidentes, já citados, possibilitou uma comparação fiel entre as duas áreas.

O solo foi classificado como Latossolo Amarelo Argiloso Distrófico, apresentando valores de análise física muito coerentes, corroborando a hipótese de se tratar de mesmo solo, sendo que as variações dos valores referentes à fertilidade na camada superficial podem ser explicados pelas práticas de manejo executadas na área de SAF (A12) (ANEXOS C, D, E). As principais referências para comparação entre as informações dos perfis, para se analisar a similaridade entre os solos, foram características relativas à cor, estrutura e análise fỉsica.

\section{1.2.2.2. Histórico das áreas}

Quanto ao histórico, a área de estudo sofreu exploração de madeira e queima e foi usada para roças de mandioca (Manihot sculenta Crantz.) sucessivas, até o esgotamento do solo, tendo então sido transformada em pasto e posteriormente 
abandonada. Com o abandono, essa área foi sendo paulatinamente coberta por uma vegetação nativa cuja fisionomia é de capoeira baixa, e há doze anos atrás, sua vegetação apresentava-se com marcante presença de sapé (Imperata brasiliensis Trin.), feto-degaiola (Pteridium aquilinum (L.) Kunn) e alguma regeneração por espécies "de terra fraca" (principalmente herbáceas da família Asteraceae e arbóreas da família Melastomataceae). Um trecho dessa área permaneceu como capoeira até hoje (referida nesse trabalho como A0), tendo ainda sido submetida a queimadas acidentais até 1989 (quando ocorreu a última). Nesse trecho a vegetação foi se desenvolvendo em manchas heterogêneas, com predominância de sapé, samambaias e espécies arbóreas da família das Melastomatáceas (principalmente a espécie Tibouchina luetzelbergii) nas bordas, e ocorrência de muitas lianas, ciperáceas e arbóreas de outras famílias no interior. Enquanto esse trecho (A0) estava submetido à regeneração natural pelo processo de pousio, outro trecho vizinho, definido como A12, foi submetido ao manejo, com roçada, introdução de um sistema agroflorestal, há 12 anos atrás, conforme descrito a seguir:

A primeira intervenção nessa A12 deu-se entre 1985 e 86, que consistiu de uma capina seletiva, cortando inteiramente, com facão, as espécies herbáceas (capins, samambaias e outras), deixando as mudas de espécies arbóreas oriundas das área florestadas do entorno por regeneração natural. Nesse período (ainda em 1986) retirouse o pouco de madeira que havia na área e adicionou-se, a lanço, $2400 \mathrm{Kg}$ calcário/ha. Após essa operação, foram semeadas à lanço algumas espécies como Pau-pombo (Tapirira guianensis) e Ingás (Inga spp.) colhidas na região e foram plantadas bananeiras (da terra e da prata no espaçamento $3 \times 3 \mathrm{~m}$ ), e também mandioca e capimelefante, ambos para corte. Entre 1988 e 89 foram plantados, a partir de sementes, cacau híbrido (da CEPLAC) e cacau comum (catongo do Maranhão) no espaçamento de 3 × 3 $\mathrm{m}$, usando as mesmas covas das bananeiras e plantado junto com sementes de mamão e de citros.

Em 1989 semeou-se também jaca (Artocarpus heterophyllus Lam.), ingás (Inga spp.), eritrinas (Erytrina spp.) inhaíba e biribeira (Eschweilera spp.), louro-folhão (Licania guianensis) e pupunha (Bactris gasipaes Kunth) com espaçamento aproximado 
de $6 \times 6 \mathrm{~m}$. Observou-se o surgimento e desenvolvimento natural de corindiba (Trema micrantha) e fidalgo (Aegiphila sellowiana Cham.).

O capim-elefante foi roçado periodicamente (três a quatro vezes por ano) para produção de biomassa e acabou desaparecendo da área. A banana produziu bem entre os anos de 1988 e 1992 (média de 618,7 cachos de $10 \mathrm{Kg} / \mathrm{ha}$.ano) e em 1994 ocorreu diminuição da produção de banana na área. A mandioca não produziu muito bem na área.

Em 1993 foi plantado abacaxi (cultivar pérola), no espaçamento 0,5 x 1,5 m nas falhas da vegetação e em locais que apresentavam desenvolvimento mais fraco da vegetação. Junto a cada muda de abacaxi foi colocada uma semente de árvore, como o sombreiro (Clitoria fairchidiana Howard), a jaca e o dandá (Johannesia princips Vell.). $\mathrm{O}$ abacaxi produziu bem nestes locais (uma fruta por pé, em três colheitas).

Em 1996, considerado um ano fraco para a agricultura, o cacau dessa área (A12) produziu uma média de $50 @$ @ha, valor esse que apresenta $14 @$ acima da média do sul da Bahia. Em 1996 plantou-se, nas falhas da vegetação florestal, consórcios de mudas de espécies mais avançadas na sucessão, regionais ou não, como: jatobá (Hymenaea courbaril L. var. stilbocarpa (Hayne) Lee et Lang.), assacu (Hura crepitans L.), mogno (Swietenia macrophylla King.), pau-brasil (Caesalpinia echinata Lam.), açaí (Euterpe

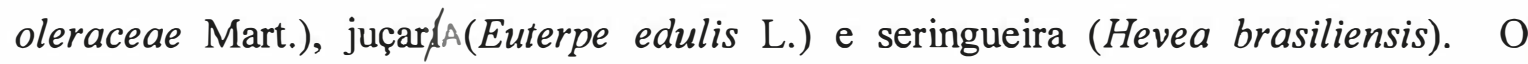
manejo dessa área (A12) consistia em duas podas/ano até 1992, e uma poda/ano de 1992 em diante.

Nesse manejo, realizou-se podas de até $70 \%$ das copas dos indivíduos arbóreos da área. A última deu-se em outubro de 1996.

A decisão para implantação de um SAF foi em função dessa região aparentar condições ambientais desfavoráveis para a produção do cacau (Theobroma cacao L.), que é uma espécie mais avançada na sucessão (mais exigente em termos de fertilidade do solo, segundo Alvim, 1977) que atuaria como indicadora da qualidade de seu trabalho de manejo na recuperação da área. 
Informações detalhadas a respeito dos conceitos que fundamentam os SAFs dirigidos pela sucessão natural e o manejo dos SAFs podem ser encontrados em Götsch (1995) e no Capítulo V.

\section{II.1.2.3. Alocação das Parcelas}

Assim que as áreas foram escolhidas, efetuou-se a demarcação das duas parcelas de estudo (A0 e A12), cada uma com 0,5 ha, onde para cada área, deveriam ser efetuados os levantamentos de vegetação (em área total, porém foram consideradas subparcelas para possibitar análise de agrupamento) e coleta de amostras de serapilheira, solos, e fauna edáfica, conforme os Coquis abaixo:

\section{Croqui 1 (A0 - Capoeira):}

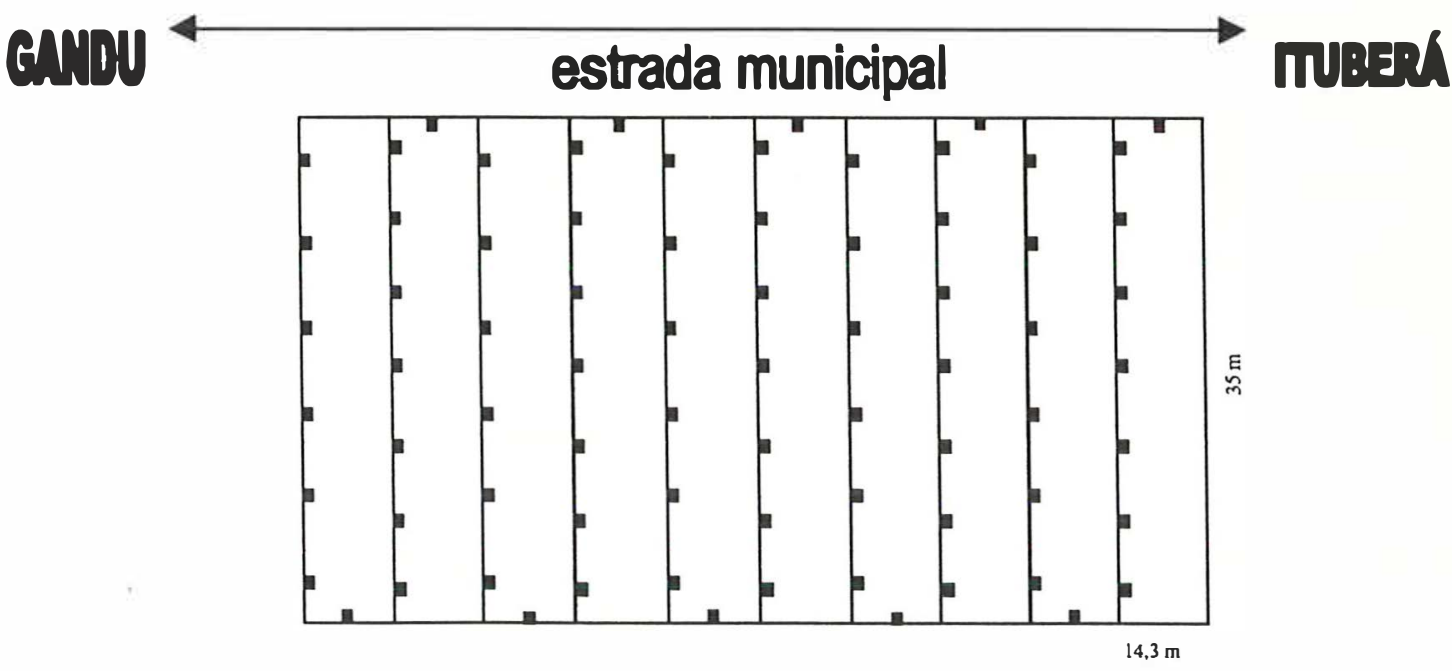

- Ponto de coleta de amostras de serapilheira, solos, e fauna edáfica 
Croqui 2 (A12 - SAF):

\section{GANDU}

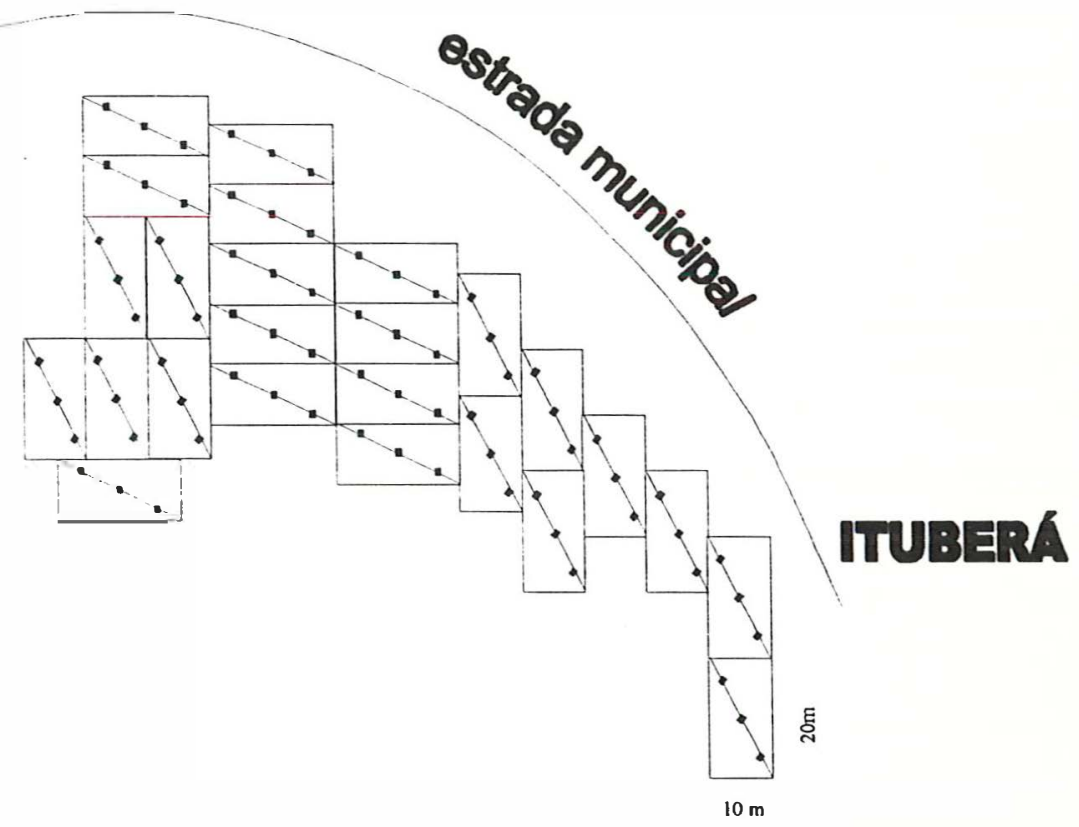

- Ponto de coleta de amostras de serapilheira, solos, e fauna edáfica 


\section{BIBLIOGRAFIA}

ALVIM, P. de T. e KOZLOWSKI, T.T. Ecophysiolgy of Tropical Crops. London: Academic Press. Inc., 1977. 502p.

BENITES, J.R. Agroforestry systems with potencial for acid soils of the humid tropics of Latin America and the Caribbean. Forest Ecology and Management, v. 36, n. 1, p. 81-101, Aug. 1990.

BROWN JR., K.S. Biogeografia e conservação das florestas atlântica e amazônica brasileiras. In: SIMPÓSIO SOBRE DESENVOLVIMENTO ECONÔMICO E IMPACTO AMBIENTAL EM ÁREA DO TRÓPICO ÚMIDO BRASILEIRO. Anais. 1987, p. 85-102.

DEAN, W. A ferro e fogo: A história e a devastação da Mata Atlêntica brasileira. São Paulo: Companhia das letras, 1996. 484p.

FONSECA, G.A.B. da. The vanishing Brazilian Atlantic Forest. Biological Conservation, v.34, p. 17-34. 1985.

JOLY, C.A.; LEITÃO-FILHO, H. de F.; SILVA, S.M. O patrimônio florístico. In: CECCHI, J.C. \& SOARES, M.S.M. (eds.). Mata Atlântica / Atlantic Rain Forest. Fundação SOS Mata Atlântica, Ed. Index., 1991. p. 95-125.

MORI, S.A. Eastern, extra-amazoniam Brazil. In: CAMPBELL, D.G. \& HAMMOND, H.D. (eds.). Floristic Inventory of tropical countries: the status of plant systems, collections and vegetation, plus recommendations for the future. New York Botanical Garden, 1989. p.427-454. 
PEIXOTO, A.L. Vegetação da costa atlântica. In: MONTEIRO, S. \& KAZ, L. (coords.). Floresta Atlântica. Rio de Janeiro: Ed. Alumbramento/Livroarte Editora, 1991/92, p. 33-42.

SANTANA, M.B.M.; CABALA-ROSAND, P.; SERÓDIO, M.H. Reciclagem de nutrientes em agroecossistemas de cacau. Agrotrópica, v.2, n. 2, p. 68-74, 1990.

SOS MATA ATLÂNTICA. Atlas da evolução dos remanescentes florestais e ecossistemas associados do domínio da Mata Atlântica no período de 19851990. São Paulo: Fundação SOS Mata Atlântica/INPE, 1993. 


\title{
III. AS ALTERAÇÕES DOS PARÂMETROS VEGETACIONAIS NUM SISTEMA AGROFLORESTAL DIRIGIDO PELA SUCESSÃO NATURAL
}

\author{
Fabiana Mongeli Peneireiro ${ }^{1}$ \\ Ricardo Ribeiro Rodrigues ${ }^{2}$
}

\section{RESUMO}

A partir de um estudo de caso sobre um sistema agroflorestal (SAF) biodiverso e orientado pela sucessão natural, comparou-se a área de SAF em questão com uma área em pousio (Capoeira) de mesmo histórico de perturbação, mesma condição ambiental e com 12 anos de manejo e abandono, respectivamente, na região de Floresta Ombrófila Densa Sub-Montana, no sul da Bahia, Brasil. Verificou-se a influência da implantação e manejo do SAF dirigido pela sucessão natural sobre os parâmetros vegetacionais, tendo como referência a área de Capoeira ou pousio.

Para isso, efetuou-se levantamento florístico e fitossiológico da vegetação em 0,5 ha de cada uma das duas áreas comparadas (A12 - SAF e A0 - Capoeira), utilizando-se dos parâmetros comumente empregados para avaliação qualitativa e quantitativa de floresta tropical, como diversidade, eqüabilidade, freqüência, densidade e dominância. Asimilaridade florística entre as áreas estudadas foi verificada através do índice de Jaccard e utilizado para análise de classificação pela média de grupo (UPGMA) e de ordenação pelo método de coordenadas principais (PCO) .

A vegetação das duas áreas estudadas (A0 - Capoeira e A 12 - SAF) mostraram-se diferentes depois de 12 anos, sendo que a áre Al2 mostrou-se mais avançada na sucessão, se comparada com a Capoeira, com destaque em densidade das famílias Mimosaceae, Lauraceae e Caesalpiniaceae, enquanto que na A0 (Capoeira) a família Melastomataceae foi a que mais se destacou em número de indivíduos. A área A12 (SAF) apresentou o maior índice de diversidade e de eqüabilidade, embora tenha apresentado menor número absoluto de espécies, se comparada com a A0 (Capoeira). Tanto a análise de classificação como de ordenação separaram claramente as parcelas da área Ao das parcelas da área A 12.

O SAF dirigido pela sucessão natural, análogo em estrutura e função às florestas tropicais mostrou-se uma alternativa promissora para a recuperação de áreas degradadas, possibilitando retorno econômico, compatibilizando produção com a conservação dos recursos naturais, inclusive biodiversidade e sem a utilização de insumos externos.

\footnotetext{
${ }^{1}$ Eng. Agr., mestranda em Ciências Florestais

${ }^{2}$ Prof. Dr. ESALQ/USP, Piracicaba
} 


\section{III.1. INTRODUÇÃO}

Uma área degradada por ação antrópica ou natural sofrerá regeneração natural, tendo sua cobertura vegetal restabelecida, num crescente em qualidade e quantidade de vida (Götsch, 1995; Martins, 1990).

Este processo de regeneração natural, que pressupõe mudança da fisionomia e das populações no espaço e no tempo, no sentido de aumento de qualidade e quantidade de vida é conhecido como sucessão natural (Götsch, 1995). Sucessão foi definida como uma "lei universal" na qual "todo lugar vazio evolui para novas comunidades exceto aqueles que apresentam condições muito extremas de água, temperatura, luz ou solo" (Clements, 1916 apud McIntosh, 1981). Uma das características universais de todo ecossistema é a mudança contínua a que está submetido (Gómez-Pompa \& Wiechers, 1976).

O processo clássico de sucessão secundária envolveria a substituição de grupos de espécies ao longo do tempo, à medida que estas predecessoras fornecessem condições mais favoráveis ao desenvolvimento das espécies já presentes na área, com crescimento lento e estabelecimento de espécies mais tardias (Egler, 1954).

Os ecossistemas naturais estão sempre mudando e essas mudanças se dão numa dupla via: i) as adaptações das espécies às condições da etapa sucessional em que se estabelece, e ii) a evolução do meio durante a sucessão e seu efeito sobre as espécies da comunidade (Gómez-Pompa \& Vazquez-Yanes, 1985). Com isso, podemos reforçar que os seres vivos alteram o ambiente e o ambiente atua sobre os seres vivos.

Diversas tendências estruturais são esperadas ao longo do processo sucessional, como o aumento da diversidade, da eqüabilidade, do número de estratos, etc., à medida que a comunidade atinge um nível estrutural mais complexo (Odum, 1969). Além do aumento da biodiversidade, são notáveis as transformações ambientais no decorrer da sucessão, como a transferência de nutrientes livres do solo para a comunidade biótica ao longo do processo, reduzindo sua perda; a melhoria da estrutura edáfica pela produção de matéria orgânica, além de modificações do microclima (Gómez-Pompa \& VazquezYanes, 1985). 
O SAF enfocado nesse estudo de caso fundamenta-se nos conceitos da sucessão natural, tendo sua implantação e manejo norteados pelos mesmos. A dinâmica do sistema, que é dada pelo manejo, é inspirada nos processos naturais, que são enfatizados por meio, principalmente, da poda e capina seletiva. Estudando-se a influência do mesmo SAF em questão sobre a fertilidade química do solo, constatou-se que houve uma sensível melhora na fertilidade química do solo, assim como houve um esboço de tendência à evolução da macrofauna edáfica em direção a estágios sucessionais mais avançados na área de SAF, se comparada com a área em pousio, o que chama a atenção para o fato de que todos os compartimentos de um sistema estão interrelacionados. O manejo foi indicado como o principal responsável pela melhoria da fertilidade do solo no sistema agroflorestal (Capítulo IV).

Procurou-se, nesse estudo de caso, conferir a influência da implantação e manejo do SAF conduzido pela sucessão natural sobre os parâmetros vegetacionais, ao estabelecer um referencial com uma área em pousio (Capoeira), com mesmas características de solo, relevo, histórico, idade e perturbação.

\section{III.2. HISTÓRICO DAS ÁREAS}

Ambas as áreas comparadas nesse trabalho (A12 - SAF e A0 - Capoeira) sofreram exploração seletiva de madeira e queima e foram usadas para roças de mandioca sucessivas, até o esgotamento do solo, tendo sido usadas como pasto e então abandonadas, há 12 anos atrás, a partir do que foi sendo paulatinamente coberta por uma vegetação nativa cuja fisionomia é referida como "capoeira fraca", com forte presença de sapé (Imperata brasiliensis Trin.), feto-de-gaiola (Pteridium aquilinum (L.) Kunn) e alguma regeneração por espécies "de terra fraca" (principalmente herbáceas da família Asteraceae e arbóreas da família Melastomataceae). As áreas sofreram ainda algumas queimas acidentais até 1989 (quando ocorreu a última). A partir dessa fisionomia comum para as duas áreas há 12 anos atrás, o histórico de cada área passou então a tomar rumos diferentes: uma foi deixada em pousio (A0) e na outra (A12) implantou-se um sistema agroflorestal, com manejo pronunciado da vegetação nesse período. 
$\mathrm{Na}$ área de Capoeira (A0), durante os 12 anos em que ficou em pousio, a vegetação foi se desenvolvendo em manchas heterogêneas, de modo que mais próximo à estrada constatou-se predominância de sapé e samambaias com ocorrência abundante de Melastomatáceas e já mais para o interior da área observou-se a ocorrência de muitas lianas, ciperáceas e arbóreas de outras famílias. Enquanto a área A0 (utilizada neste trabalho como referência para comparação) se submetia à regeneração natural devido ao pousio, a área A12 (SAF) foi roçada, e introduziu-se um sistema agroflorestal onde seguiram-se as seguintes operações de instalação e manejo:

A primeira intervenção na área se deu no segundo semestre de 1985 e consistiu em capina seletiva, cortando-se inteiramente, com facão, as espécies herbáceas (capins e samambaias) principalmente, deixando as mudas de espécies arbóreas da regeneração natural que apareceram espontaneamente (na maioria, Pau-pombo - Tapirira guianensis Aubl. e Ingá - Inga blanchetiana e Inga thibaudiana) e retirou-se o pouco de madeira (tanto caída como ainda em pé) que havia na área. Foram semeadas à lanço as espécies Pau-pombo (Tapirira guianensis Aubl.) e Ingá (Inga spp.) e foram plantadas bananeiras (da terra e prata) no espaçamento $3 \times 3 \mathrm{~m}$, e também mandioca (Manihot sculenta) e capim-elefante, ambos para corte. Depois de dois anos foram plantados, a partir de sementes, cacau híbrido (da CEPLAC) e comum (catongo do Maranhão) com espaçamento de $3 \times 3 \mathrm{~m}$ na covas das bananeiras, junto com mamão e citros.

No terceiro ano semeou-se também jaca (Artocarpus heterophyllus Lam.), ingás (Inga spp.), eritrina (Erytrina poeppigiana), inhaiba e biribeira (Eschweilera sp.), lourofolhão (Licaria guianensis), louro-jibóia (Ocotea sp.) e pupunha (Bactris gasipaes Kunth), intercaladas e com espaçamento aproximado de $6 \times 6 \mathrm{~m}$. Observou-se o surgimento e desenvolvimento natural de corindiba (Trema micrantha (L.) Blum.) e fidalgo (Aegiphila sellowiana Cham.).

A mandioca foi colhida e o capim-elefante foi roçado periodicamente (três a quatro vezes por ano) para produção de biomassa e acabou desaparecendo da área. A banana predominou no consórcio até o oitavo ano desde a implantação do SAF, a partir do que houve declínio da produção de banana na área e as arbóreas passaram a dominar. 
Foi plantado abacaxi (cultivar pérola), no espaçamento 0,5 x 1,5 m nas falhas da vegetação e em locais que apresentavam desenvolvimento mais fraco da vegetação. Junto a cada muda de abacaxi foi colocada uma semente de árvore como sombreiro (Clitoria fairchidiana Howard), jaca (Artocarpus heterophyllus Lam.) e dandá (Joannesia princips Vell.).

$\mathrm{O}$ manejo da área consistiu em duas podas ao ano até o quinto ano do SAF, e uma poda por ano a partir de então.

Quando as bananeiras dominavam o sistema e já entravam em declínio, plantouse, nas falhas, consórcios de mudas de espécies definidas como "do futuro na sucessão" de ocorrência regional ou não, como: jatobá (Hymenaea courbaril L. var. stilbocarpa (Hayne) Lee et Lang.), assacu (Hura crepitans L.), mogno (Swietenia macrophylla King.), pau-brasil (Caesalpinia echinata Lam.), açaí (Euterpe oleraceae Mart.), juçarj/A (Euterpe edulis Mart.) e seringueira (Hevea brasiliensis M. Arg.).

Quanto ao manejo, realizou-se podas de $70 \%$ das copas das arbóreas nativas. A última deu-se em outubro de 1996 (a coleta dos dados realizou-se de fevereiro a abril de 1997).

O cacau (Theobroma cacao L.) foi utilizado no SAF como uma espécie indicadora da eficiência do manejo, uma vez que trata-se de uma espécie exigente em umidade e fertilidade do solo (Alvim \& Koslowski, 1977; Benites, 1990), classificada como de consórcios mais avançados na sucessão, já que o objetivo das intervenções no SAF era o avanço sucessional e a recuperação da fertilidade do solo.

Embora não seja ainda considerado, por seu idealizador, um modelo ideal de $\mathrm{SAF}$, os conceitos fundamentais que foram utilizados para sua elaboração e manutenção, como a introdução e condução de consórcios, a capina seletiva e a poda foram sendo aperfeiçoados ao longo desses anos de experiência e aprendizado, sendo que todas as operações (desde a instalação dos consórcios e o manejo, como poda e seleção das espécies) são realizadas obedecendo-se à lógica sucessional, baseadas em critérios como estratos, ciclo de vida, exigência em nicho, ordem de recrutamento relativo entre as espécies, etc., utilizando-se de informações sobre como as espécies se comportam no ecossistema natural, compreendendo o papel da espécie econômica a ser introduzida no 
SAF dentro do processo sucessional, compondo todo o sistema produtivo a partir desses conceitos.

Informações mais detalhadas a respeito da elaboração, implantação e manejo do SAF podem ser encontradas no Capítulo V.

\section{III.3. METODOLOGIA}

O método utilizado para a caracterização fitossociológica da vegetação foi o de parcelas (Mueller-Dombois \& Ellenberg, 1974). Foram distribuídas nas duas áreas de 0,5 ha estudadas. sub-parcelas de $20 \mathrm{~m} \times 10 \mathrm{~m}$ e de $35 \mathrm{~m} \times 14,3 \mathrm{~m}$, respectivamente para A12 (SAF) e A0 (Capoeira). Em cada sub-parcela foram amostrados todos os indivíduos de espécies arbóreas nativas que apresentassem diâmetro à altura do peito (a $1,30 \mathrm{~m})$, maior ou igual a $5 \mathrm{~cm}$ ( DAP $\geq 5 \mathrm{~cm})$.

No caso das árvores que possuiam ramificações, além do tronco principal, todos os outros tiveram seus perímetros medidos. Para que fossem incluídos na amostragem era necessário que pelo menos uma ramificação possuísse DAP $\geq 5 \mathrm{~cm}$.

Para coleta do material botânico utilizou-se tesoura de alta poda e algumas árvores tiveram que ser escaladas. De cada indivíduo amostrado foi coletado material botânico para identificação, diâmetro na altura do peito (1,30 m de altura), e outras informações que poderiam auxiliar a identificação da planta, como presença e cor de látex, características do tronco, como aroma, cor, e aspectos característicos da casca, entre outras.

A identificação botânica foi realizada a partir de consultas a herbários e auxílio de especialistas.

De posse dos dados de número de espécies, número de indivíduos por espécie, DAP e altura dos indivíduos arbóreos, foi possível identificar os parâmetros comumente empregados para avaliação quantitativa de floresta tropical, como diversidade, eqüabilidade, índice de valor de importância (IVI), freqüência, densidade e dominância absolutos e relativas. O cálculo dos parâmetros foi realizado com auxílio do programa FITOPAC (Shepherd, 1995). 
A similaridade florística entre as áreas estudadas foi testada usando-se o índice de Jaccard. A matriz de similaridade foi usada para análise de classificação utilizandose o método de média de grupo (UPGMA) e para análise de ordenação usando o método de coordenadas principais (PCO), conforme recomendação de IVANAUSKAS et al, 1999). As análises de classificação e de ordenação também foram feitas pelo programa FITOPAC (Shepherd, 1995).

\section{III.4. RESULTADOS E DISCUSSĀO}

O levantamento florístico possibilitou a identificação das espécies que ocorrem nas duas áreas comparadas, apresentadas nos ANEXOS F e G.

Foram obtidos dados fitossociológicos para as duas áreas, sendo que na A12 (SAF) os dados obtidos foram relativos a três situações: i) considerando-se apenas as espécies arbóreas nativas; ii) considerando-se as espécies nativas e as não regionais introduzidas, sem exploração econômica e iii) considerando-se as espécies nativas, as não regionais introduzidas, inclusive as exploradas economicamente.

$\mathrm{Na}$ área 12, para o primeiro caso analisado (i) foram amostrados 206 indivíduos vivos, 27 famílias, 42 gêneros e 51 espécies (ANEXO I). A densidade total foi de 412 indivíduos/ha, com uma área basal total de $5,254 \mathrm{~m}^{2} / \mathrm{ha}$, definido numa fisionomia tipicamente florestal, multiestratificada e biodiversa.

$\mathrm{Na}$ análise fitossociológica onde foram incluídas, além das arbóreas nativas, aquelas espécies não regionais introduzidas e não exploradas economicamente (ii), obteve-se 648 indivíduos/ha, 29 famílias, 56 espécies, com área basal total de 9,342 $\mathrm{m}^{2} /$ ha. Tanto no primeiro quanto no segundo caso, a família Lauraceae apresentou a maior riqueza, ou número de espécies. Quanto à densidade por família, no primeiro caso, a família Mimosaceae ocupou o primeiro lugar, com 41 indivíduos, enquanto que no segundo caso, foi a família Sterculiaceae, com 47 indivíduos, seguida de perto pela Moraceae, com 43 indivíduos (representadas pelas jaqueiras e pelos patastes).

As espécies de interesse econômico ou alimentar, que foram introduzidas na área A12, foram contadas separadamente, correspondendo, no 0,5 ha levantado, a 543 pés de 
cacau, 286 pés de banana-prata, 46 pés adultos de pupunha, 43 jaqueiras adultas e 499 mudas de jaqueira, 47 pés de pataste (Theobroma bicolor Willd.), 1 lima da persa, 8 abacateiros, 13 eritrina (Erythrina poeppigiana) e 6 sombreiro-mexicano (Clitoria fairchildiana). Assim, no terceiro caso (iii), têm-se que, somadas todas as espécies introduzidas aos indivíduos de ocorrência natural, totalizam 1826 indivíduos/ha (DAP $\geq$ $5 \mathrm{~cm}$ ), de 30 famílias, 49 gêneros e 58 espécies.

$\mathrm{Na}$ área de capoeira (A0), utilizada como referência, foram levantados 429 indivíduos vivos, de 39 famílias, 65 gêneros e 73 espécies (ANEXO H), resultando num total de 858 indivíduos/ha com DAP $\geq 5 \mathrm{~cm}$, com área basal de $9,207 \mathrm{~m}^{2} / \mathrm{ha}$. A fisionomia da vegetação nessa área mostrava-se muito heterogênea, sem estratos definidos e dossel muito irregular, com muitas espécies de lianas (123 morfoespécies), de herbáceas, indivíduos jovens de espécies arbóreas e arbustivas.

Algumas famílias podem ser características de um ambiente particular ou de uma certa condição geográfica. Determinadas famílias indicam um certo ambiente, ou representam um estádio sucessional ou ainda, fornecem algumas informações geográficas sobre a área onde estão localizadas (Del Moral \& Denton, 1977). No caso as área A0, a família Melastomataceae, que ocorreu em grande densidade (216 indivíduos), destacando-se muito das demais famílias amostradas (Figura 2), indica uma fase de desenvolvimento sucessional mais inicial que a área A12 (SAF), onde não foi amostrado nenhum indivíduo dessa família, constatando-se um decréscimo gradual da densidade entre as famílias, com destaque para as famílias Leguminosae e Lauraceae, que ocorrem em estágios mais avançados da sucessão (Leitão-Filho et al., 1993; Mantovani, 1993). Além da família Melastomataceae, outras famílias como Asteraceae e Cecropiaceae ocorrendo entre as dez de maior densidade na área A0, confirmam a condição sucessional mais inicial dessa áreas (Figura III.1). Para a área A12 não ocorreu destaque em densidade de uma única família como ocorreu em A0 (Fig. III.1), sendo que as famílias que mais se destacaram foram Mimosaceae e Lauraceae (se não forem incluídas as espécies não regionais introduzidas).

Na A12 (SAF), Mimosaceae foi a família melhor representada, se só forem consideradas as espécies nativas (se forem consideradas as introduzidas, ela aparece 
depois da Sterculiaceae e Moraceae, famílias do pataste - Theobrama bicolor e da jaqueira - Artocarpus heterophyllus Lam., plantas exóticas, introduzidas no SAF), encabeçando as listas de famílias classificadas quanto à densidade e número de espécies, sendo que Fabaceae e Caesalpiniaceae ficaram abaixo desta colocação $\left(3^{\circ}\right.$ e $4^{\circ}$ lugares, respectivamente, nas listas, se forem consideradas as introduzidas eritrina e sombreiro e $3^{\circ}$ e $24^{\circ}$ lugares se não forem consideradas essas espécies).

Entretanto, se estas famílias fossem agrupadas em Leguminosae, esta seria a primeira entre família com a maior densidade absoluta (60 indivíduos) e se as eritrinas e sombreiros (espécies leguminosas introduzidas) fossem contabilizados a densidade também seria a maior, com o valor de 79 indivíduos. Leguminosae seria a segunda em número de espécies (4), junto com Euphorbiaceae e Lecythidaceae, sem contabilizar as espécies introduzidas.

É interessante mencionar que a família Leguminosae é a mais dominante nos neotrópicos (Gentry, 1988). Ao dividir a família Leguminosae em três (Caesalpiniaceae, Fabaceae e Mimosaceae), conforme proposta de Cronquist (1981), provocou-se uma diminuição da contribuição de Leguminosae à flora deste trecho de Mata Atlântica estudado. Este fato também foi ressaltado por Mantovani (1993).

$\mathrm{Na}$ A0 (Capoeira), as famílias Mimosaceae e Fabaceae, apresentaram-se em $12^{\circ}$ lugar na lista de famílias classificadas quanto à densidade absoluta e a Caesalpineaceae o $10^{\circ}$ lugar. Quanto ao número de espécies, essas famílias ocuparam os $5^{\circ}, 2^{\circ}$ e $4^{\circ}$ lugares, respectivamente (ANEXO H). Entretanto, se estas famílias fossem agrupadas em Leguminosae, esta família ocuparia, entre as demais famílias, quanto à densidade absoluta, o $5^{\circ}$ lugar (juntamente com as famílias Lauraceae) e quanto ao número de espécies, o $1^{\circ}$ lugar (juntamente com Melastomataceae, com 7 espécies).

Conforme a Figura III.1, na área de Capoeira (A0) é evidente o destaque em densidade da família Melastomataceae, enquanto que na área A12 (SAF), as famílias Sterculiaceae e Moraceae apresentaram os maiores números de indivíduos (pois foram introduzidos jaca e pataste em grande quantidade). Porém, se forem consideradas 
somente as espécies arbóreas nativas na A12, a contribuição das famílias mostram-se mais eqüitativas do que na $\mathrm{A} 0$, sem muitos indivíduos de apenas uma família ou espécie.

A0

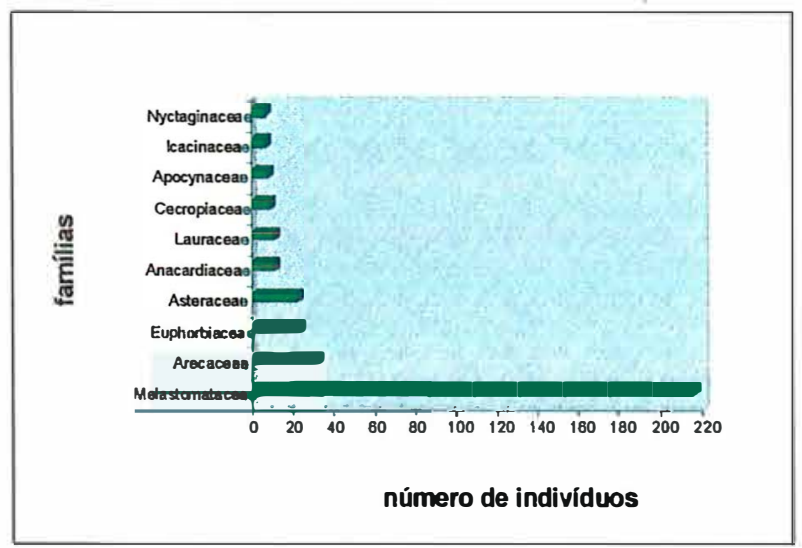

A12

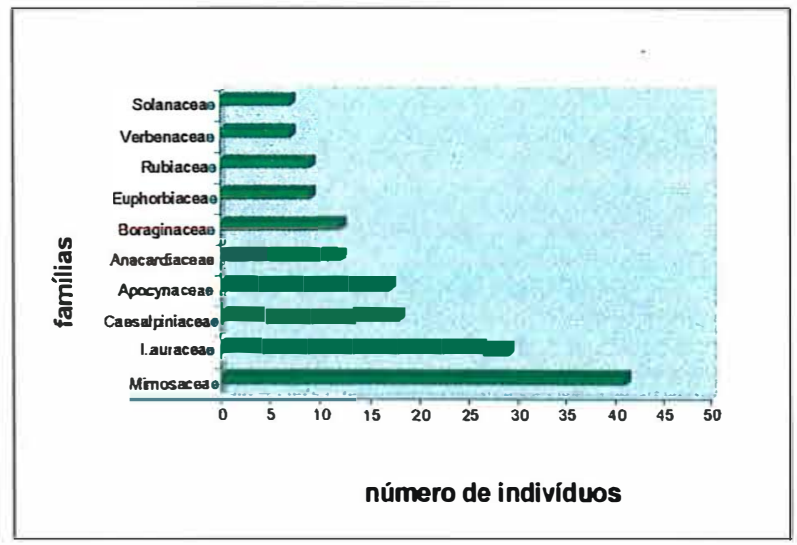

Figura III. 1 - Número de indivíduos por família (das 10 famílias com mais indivíduos) para A0 (Capoeira) e A12 (SAF) respectivamente, município de Ituberá, Bahia, Brasil.

As florestas da região Norte do Espírito Santo e do Sul da Bahia foram apontadas como sendo os últimos remanescentes de florestas virgens da região Leste do Brasil, localizadas perto de grandes centros de concentração de população (Heinsdijk et al., 1965) e a Mata Atlântica dessa região (sul da Bahia e Espírito Santo) é tida como das mais biodiversas entre as florestas do globo (Thomaz, 1996; Dean, 1996). Numa área amostral de 1 hectare, num gradiente altitudinal da vegetação florestal de Santa Lúcia (ES) foram amostrados 476 espécies arbustivo-arbóreas por ha (Thomaz, 1996).

A diversidade de uma comunidade pode ser medida através do índice de Shannon, que expressa a igualdade relativa ou a eqüitabilidade do valor de importância, diretamente, com todas as espécies em seqüência. Para Martins (1991), embora este índice seja influenciado pela amostragem, ele fornece uma boa indicação da diversidade de espécies e pode ser utilizado para comparar florestas de diferentes locais.

Os valores de diversidade para trechos de Mata Atlântica variam de 3,61 a 4,07 (nats) (Martins, 1991). Em Santa Catarina, analisando diferentes formas de vida, alcançaram valores variando de 1,43 a 3,72 (nats). Para o interior de São Paulo foram 
obtidos valores entre 3,00 a 4,06 (nats), de acordo com Mantovani (1993). Em uma área alterada no Rio Moji, região de Cubatão - SP, obtiveram um índice de diversidade de 2,14 (nats) e, na amostra geral no Rio Pilões (menos degradada) encontraram um valor igual a 4,31 (nats) (Leitão Filho et al., 1993).

Vários fatores podem interferir nos índices de diversidade obtidos, seja pelo método de amostragem e/ou pelo critério de inclusão dos indivíduos. A diversidade é um reflexo de dois componentes: a riqueza em espécies e a eqüabilidade (Mantovani, 1993).

Para a área A12 (SAF), o índice de diversidade de Shannon (H') para as espécies foi de 3,363 nats, com 51 espécies amostradas (considerando-se apenas as arbóreas nativas), enquanto que para a A0 (Capoeira) foi de 3,010 nats, com 73 espécies amostradas. A área A12 apresentou para eqüabilidade ( () o valor de 0,855 (considerando-se apenas as arbóreas nativas), enquanto que na área $\mathrm{A} 0$, o valor foi de 0,702 . Se forem consideradas também as espécies não regionais introduzidas e não exploradas economicamente na área A12, o H' passa a ser 3,281 e o valor de J, 0,815.

$\mathrm{O}$ índice de Shannon indicou que a área A12 (SAF) é mais biodiversa que a A0, apesar de apresentar menor número de espécies, pois a eqüabilidade na $\mathrm{A} 12$ foi maior, com contribuição mais eqüitativa entre as espécies na comunidade do que na A0 (Figura III.2), onde há predominância de poucas espécies arbóreas (a espécie Thibouchina luetzelbergii é, de longe, a que mais domina, com 152 indivíduos levantados) (Fig. III.2 e III.3) e de poucas famílias (a Melastomataceae é evidentemente dominante, sendo que dos 429 indivíduos levantados, 216 pertenciam a esta família). 
A0
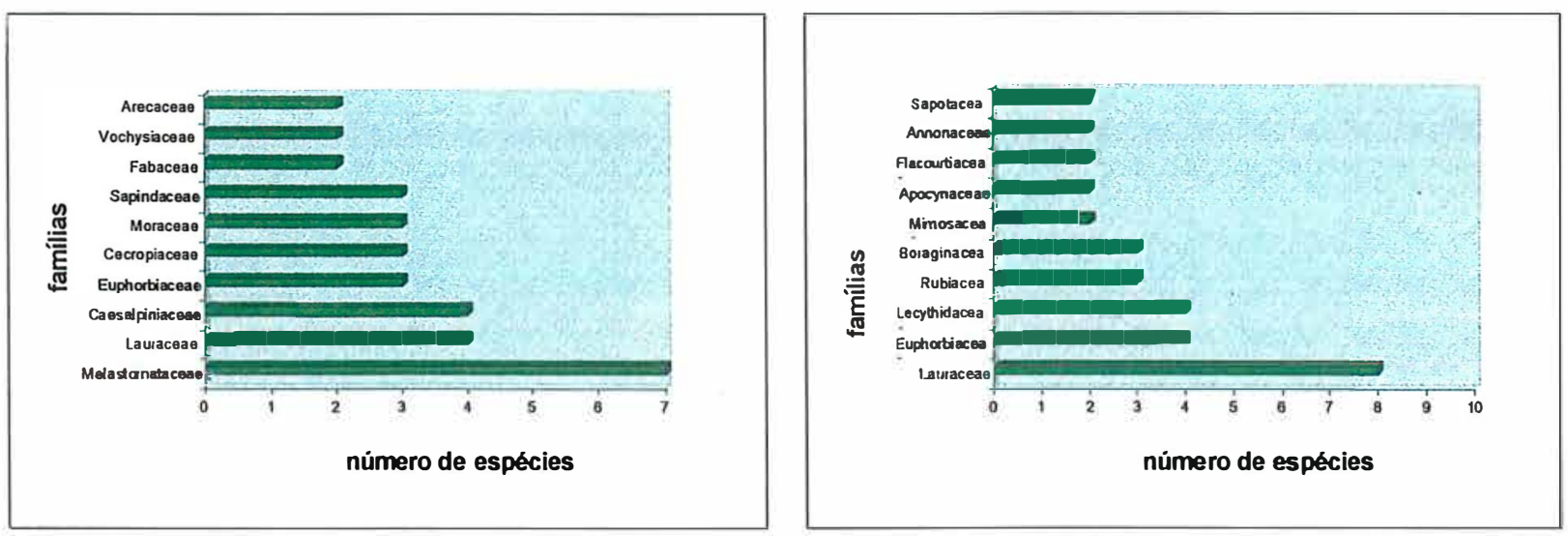

Figura III.2 - Número de espécies por família (das 10 famílias com mais espécies) para A0 (Capoeira) e A12 (SAF) respectivamente, município de Ituberá, Bahia, Brasil.

Os gráficos abaixo (Figura III.3) evidenciam claramente que na área A0 (Capoeira) uma única espécie da família Melastomataceae (Thibouchina luetzelbergii Mark Gr.) se destacou claramente entre as demais, sendo, sem dúvida, uma espécie característica do consórcio dominante na sucessão.

A0

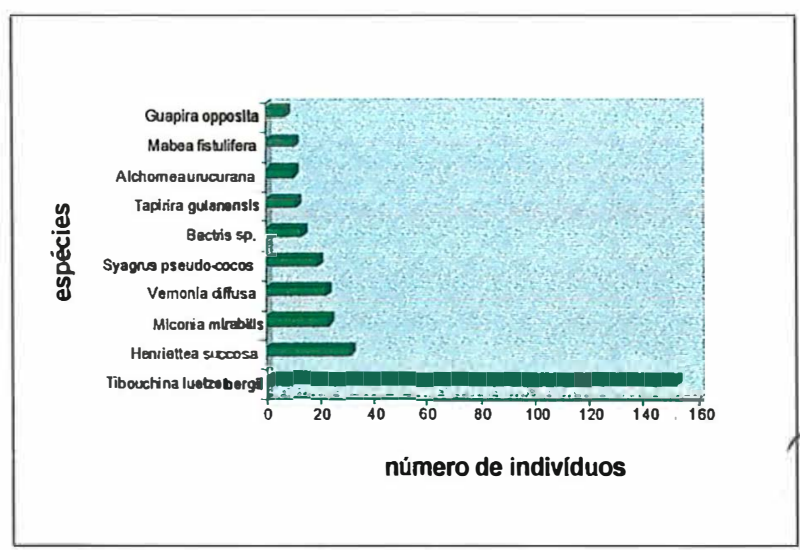

A12

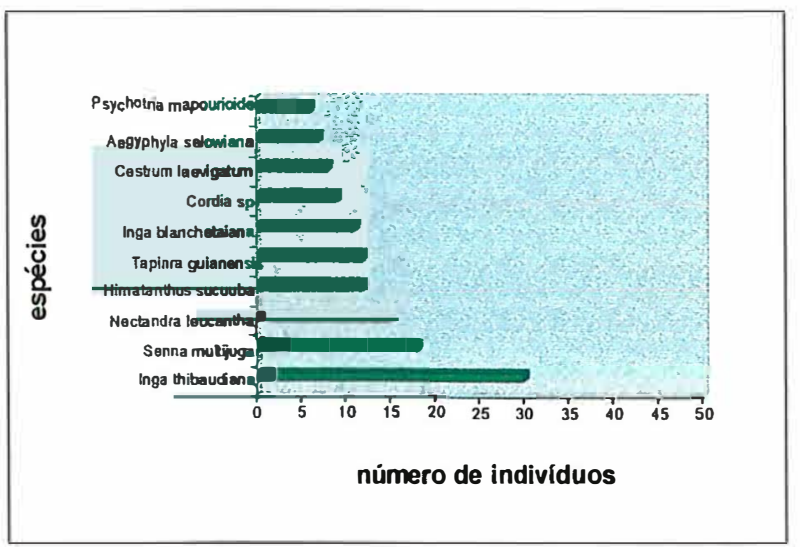

Figura III.3 - Número de indivíduos por espécie (das 10 espécies com mais indivíduos) para A0 (Capoeira) e A12 (SAF) respectivamente, município de Ituberá, Bahia, Brasil. 
Reforçando o comportamento das espécies para as duas áreas, nos gráficos abaixo (Figura III.4) observa-se claramente que na A12 há um equilíbrio quanto à participação das espécies na área, enquanto que na A0 (Capoeira), uma espécie se destacou muito no IVI (índice de valor de importância), com relação a todos os parâmetros que contribuem para o índice (Densidade Relativa, Dominância Relativa e Freqüência Relativa).

A0

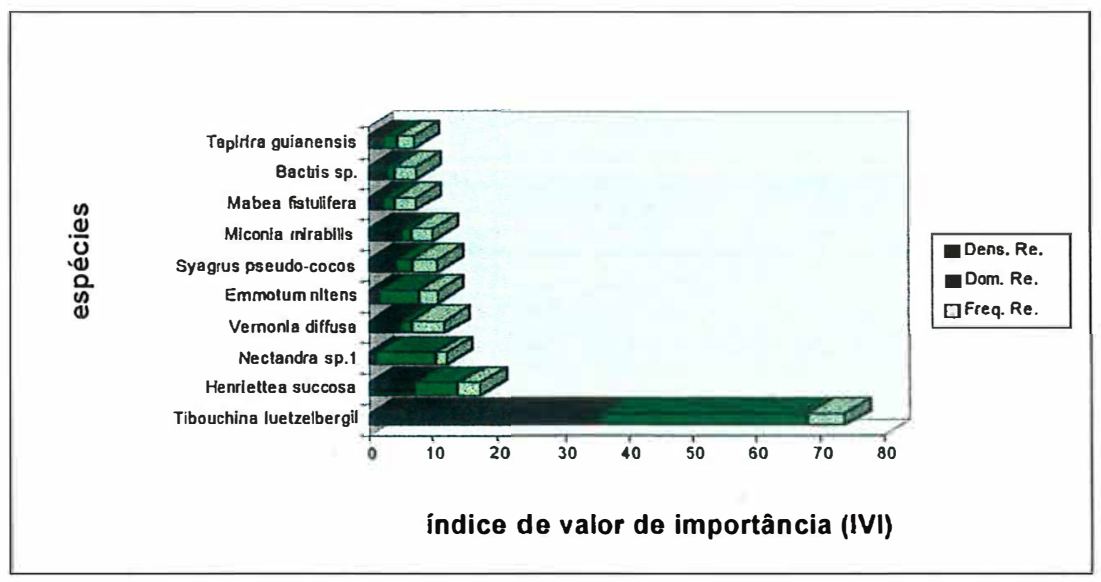

A12

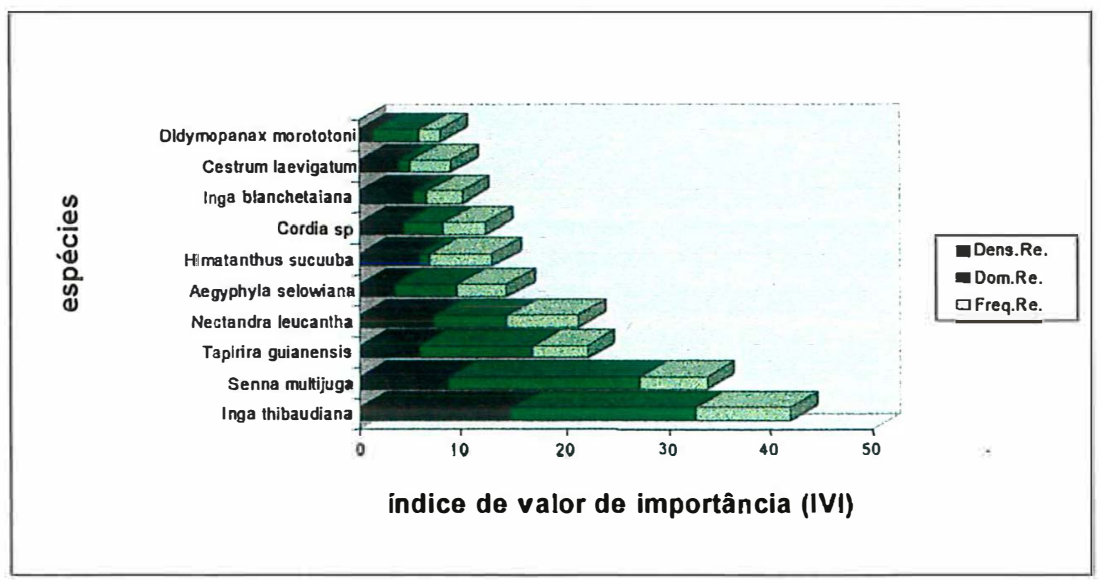

Figura III.4 - Índice de valor de importância (IVI = densidade relativa + dominância relativa + freqüência relativa) para as 10 espécies de maior IVI para A0 (Capoeira) e A12 (SAF) respectivamente, município de Ituberá, Bahia, Brasil. 
A sucessão tem sido estudada intensivamente nos últimos cem anos, com modelos de sucessão sendo descritos para diferentes comunidades vegetais em várias partes do planeta (Luken, 1990). Apesar disto, devido principalmente à grande diversidade e falta de conhecimentos básicos sobre a flora, os estudos sobre sucessão secundária em ecossistemas tropicais são ainda escassos, e de acordo com GomezPompa \& Wiechers (1976), seus resultados dificilmente podem ser extrapolados, mesmo para regiões ecológicas similares. Götsch (1995) sugere que se as espécies forem devidamente encaixadas no "Gráfico Vetorial da Vida" (ANEXO U) a partir de suas características similares e funções ecofisiológicas, torna-se possível elaborar e conduzir sistemas de produção dirigidos pela sucessão natural (SAF), para cada local específico. Elaborar SAFs e manejá-los a partir dos conceitos sucessionais pode ser possível acelerar o processo sucessional e contribuir para a conservação e aumento da biodiversidade (Götsch, 1995) como justamente mostram os dados aqui apresentados, relativos a este estudo de caso.

Na comparação entre as áreas A0 e A12, a análise de Cluster (Figura III.5) mostra a distribuição agregada das parcelas por área e caracteriza dois grupos bem distintos, o das parcelas da área A12 (P1 a P25), apenas considerando-se as espécies arbóreas nativas, e o das parcelas da área A0 (P26 a P35), além de mostrar também uma boa separação da A12 (SAF) em pelo menos quatro sub-grupos. A mesma análise, considerando-se também as espécies não regionais introduzidas, sem exploração econômica, na A12, mostrou esse mesmo comportamento. 


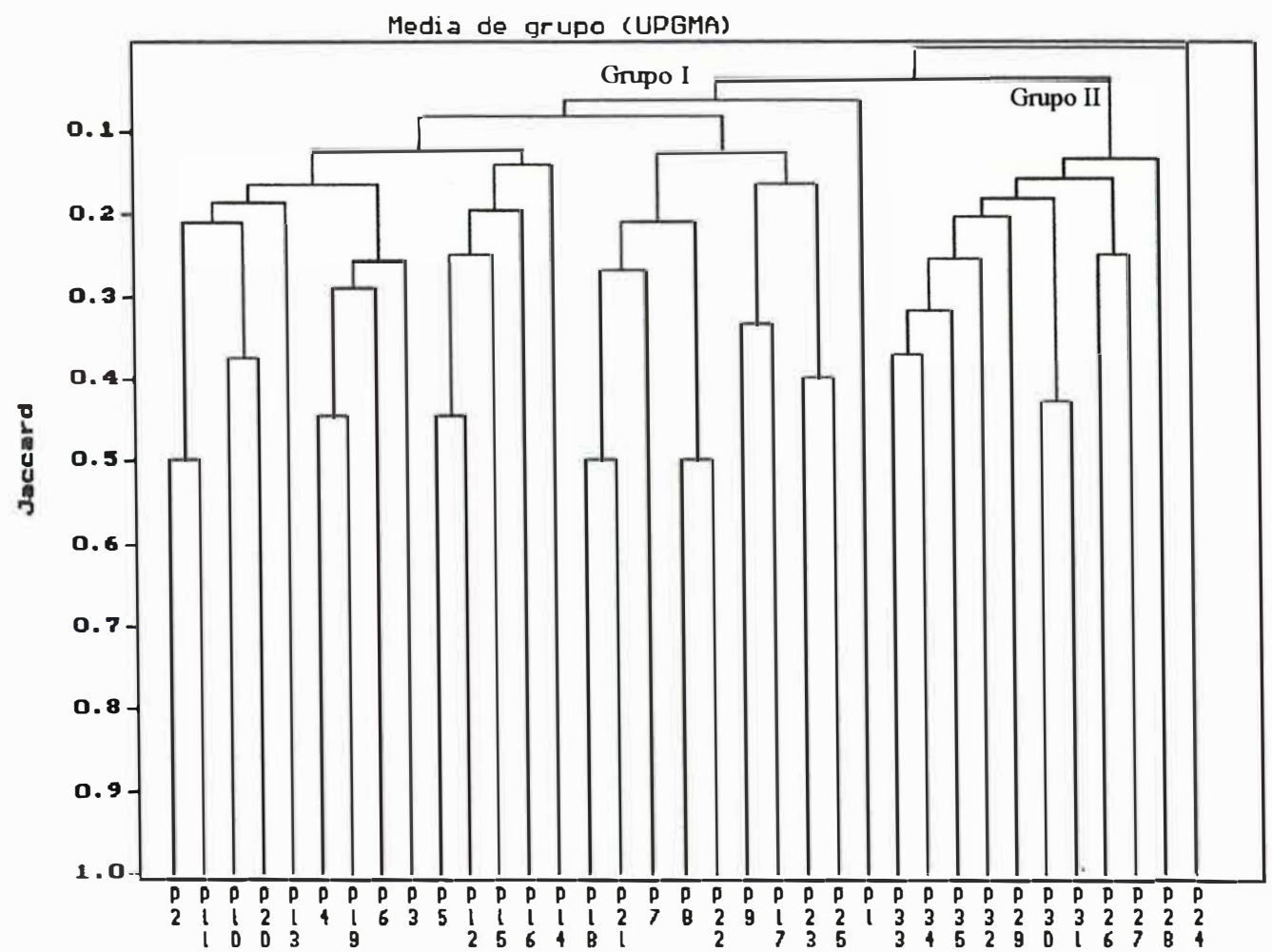

Figura III.5 - Análise de agrupamento (Cluster analise) para as parcelas das duas áreas comparadas, A12 (SAF) de P1 a P25 e da A0 (Capoeira) de P26 a P35, município de Ituberá, Bahia, Brasil.

A análise de coordenadas principais (PCO) confirmou os resultados da classificação, separando claramente os dois conjuntos de parcelas nos três eixos. O eixo 1 permitiu a constatação de uma nítida separação em dois grupos (A0 e A12). O eixo 2 mostra a heterogeneidade das parcelas da A12, em função das características sucessionais, confirmando os resultados ca classificação (Figura III.6). 


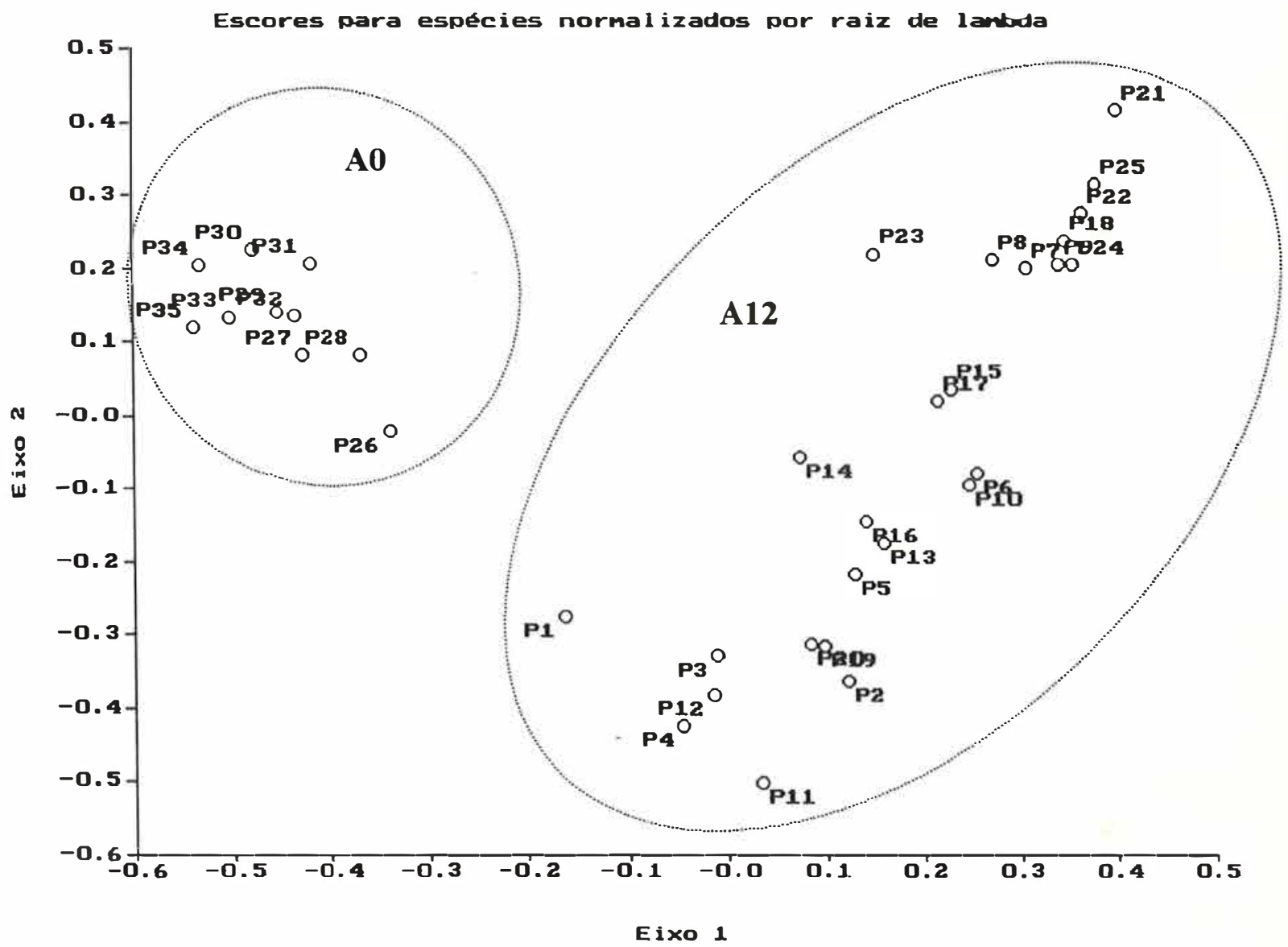

Figura III.6 - Diagrama de ordenação das parcelas, baseado nos eixos 1 e 2 da PCO (Ordenação de Coordenadas Principais), através dos dados de presença e ausência de espécies amostradas no levantamento fitossiológico, evidenciando as duas áreas estudadas (A0 - Capoeira e A12 - SAF), município de Ituberá, Bahia, Brasil. 


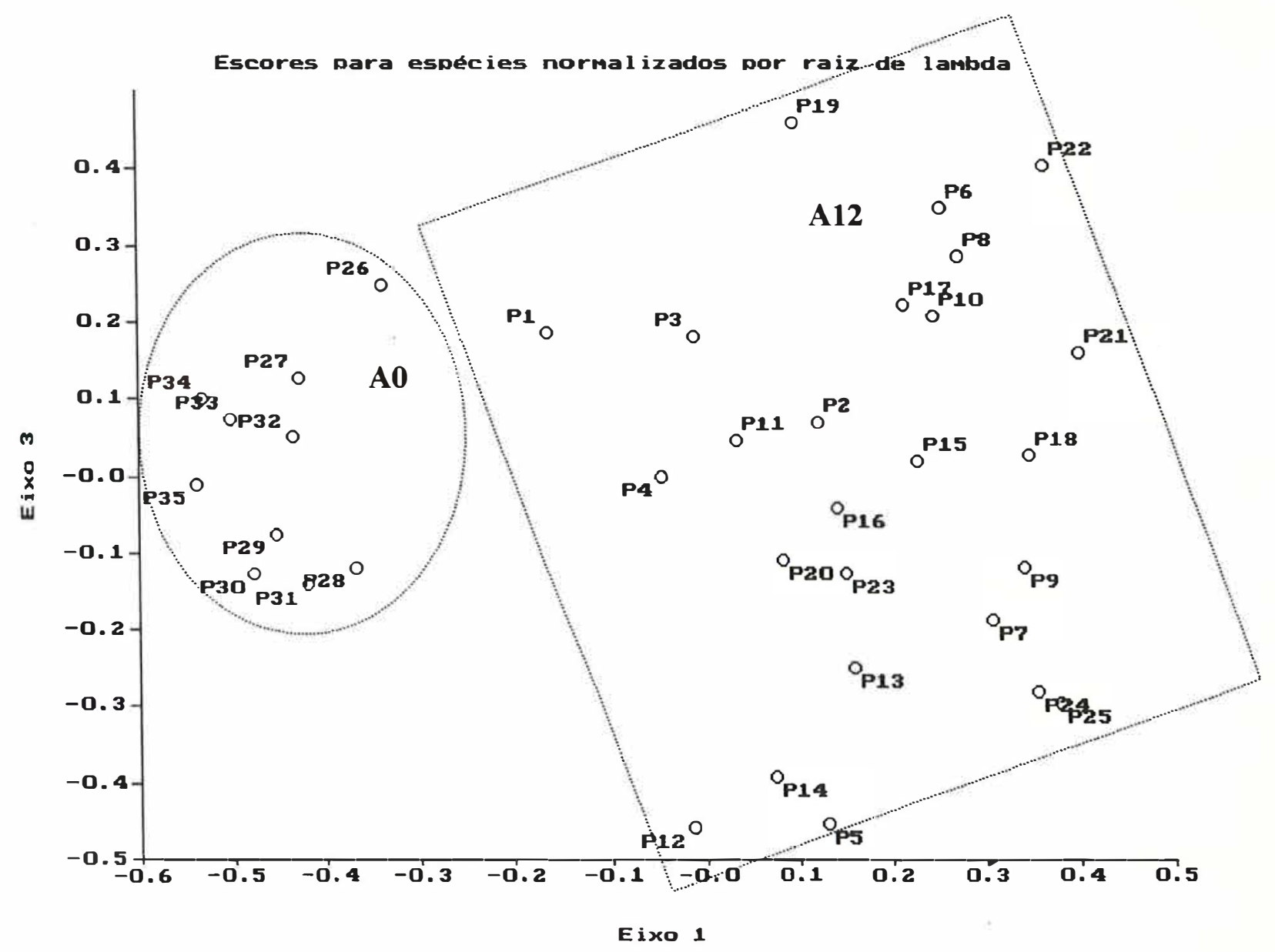

Figura III.7 - Diagrama de ordenação das parcelas, baseado nos eixos 1 e 3 da PCO (Ordenação de Coordenadas Principais), através dos dados de presença e ausência de espécies amostradas no levantamento fitossiológico.

O diagrama baseado nos eixos 1 e 3 (Figura III.7) confirma as diferenças entre a área manejada e a capoeira em termos florísticos, deixando claro que as parcelas da área A12 são mais heterogêneas que de A0, que pode ser resultado de manejo diferenciado ou da expressão (ANEXO K) da heterogeneidade dos nichos. Essas análises confirmam que as áreas $\mathrm{A} 0$ e $\mathrm{A} 12$ são distintas quanto à vegetação.

Os autovalores dos eixos 1, 2 e 3 da PCO aplicada na comparação das duas áreas amostradas quanto às espécies amostradas em levantamento fitossociológico encontramse na Tabela III.1: 
TABELA III.1: Autovalores e percentual de variação dos eixos 1, 2 e 3 da PCO aplicada na comparação das duas áreas amostradas quanto às espécies amostradas em levantamente fitossociológico

\begin{tabular}{cc}
\hline Eixo & Autovalor (\%) \\
\hline 1 & 26,68 \\
2 & 21,84 \\
3 & 17,78 \\
\hline
\end{tabular}

\section{III.5. CONCLUSÃO}

1. A vegetação das duas áreas estudadas A0 - Capoeira e A12 - SAF mostraram-se diferentes florística e estruturalmente depois de 12 anos, ao se efetuar manejo em uma (A12) e ter deixado em pousio a outra (A0);

2. Observou-se um avanço sucessional na A12 (SAF) se comparado com A0 (Capoeira), com marcante presença de indivíduos das famílias Mimosaceae, Lauraceae e Apocinaceae (encabeçando a lista quanto ao número de indivíduos por família, enquanto que na A0 (Capoeira) a família Melastomataceae apresentou-se disparadamente a que mais predominou quanto ao número de indivíduos;

3. A A12 (SAF) apresentou maior diversidade, embora tenha apresentado menor número absoluto de espécies, se comparada com a A0 (Capoeira); as espécies da área de SAF mostraram-se eqüitativamente contribuindo para a diversidade (mostrando um alto grau de eqüabilidade), enquanto que na área de Capoeira, houve predomínio de algumas espécies, principalmente da família Melastomataceae, característica de áreas degradadas ou em início de sucessão. 


\section{BIBLIOGRAFIA}

ALVIM, P. de T. e KOZLOWSKI, T.T. Ecophysiolgy of Tropical Crops. London: Academic Press. Inc., 1977. 502p.

BENITES, J.R. Agroforestry systems with potencial for acid soils of the humid tropics of Latin America and the Caribbean. Forest Ecology and Management, v. 36, n. 1, p. 81-101, aug. 1990.

CRONQUIST, A. An integrated system of classification of flowering plants. New York: Columbia University Press., 1981. 1262p.

DEAN, W. A ferro e fogo: A história e a devastação da mata Atlêntica brasileira. São Paulo: Companhia das letras, 1996. 484p.

DEL MORAL, R.; DENTON, M.F. Analysis and classification of vegetation based on family composition. Vegetatio, v. 34, n.3, p. 155-165, 1977.

CLEMENTS, F.E. Plant succession: prar analysis of the development of vegetation. Carnegie Inst: Wasshington Publ. v. 242, p. 3-4, 1916.

EGLER, F. E. Vegetation science concepts. Inicial floristic composition, a factor in oldfield vegetation development. Vegetatio, v. 4, p. 412-7, 1954.

GOMEZ-POMPA, A. \& WIECHER, B.L. Regeneratión de los Ecossistemas Tropicales y Subtropicales. In: GOMÉZ-POMPA, A.; RODRÍGUEZ, S. del A.; VÁSQUEZYANES, C.; CERVERA, A.B. (eds). Invertigaciones sobre la Regeneracion de Selvas Altas en Vera Cruz, México. México: Compañia Editora Continental, 1976. p. 11-30. 
GOMEZ-POMPA, A. \& VÁSQUEZ-YANES, C. Estudios sobre la regeneración de selvas en regiones calido-humedas de Mexico. In: GÓMEZ-POMPA, A.; DEL AMO, R. (eds.). Investigaciones sobre la Regeneratión de Selvas Altas en Vera Cruz, México. México: Compañia Editora Continental, 1985. Cap. 1, p. 1-27.

GENTRY, A.H. Changes in plant community density and floristic composition on environmental and geographical gradients. Annal of the Missouri Botanical Garden, v.75, n.1, p. 1-34, 1988.

GÖTSCH, E. Break-thropugh in agriculture. Rio de Janeiro: AS-PTA, 1995. 22p.

HEINSDIJK, E.; MACEDO, J.G. de; ANDEL, S.; ASCOLY, R.B. A floresta do Norte do Espírito Santo: Dados e conclusões de um inventário florestal piloto. Boletim do Serviço Florestal de Inventários Florestais, n.7, p. 1-69, 1965.

IVANAUSKAS, N.M; MONTEIRO, R; RODRIGUES, R.R. Similaridade florística entre áreas de Floresta Atlântica no Estado de S. Paulo. Revista Brasileira de Botânica, 1999 (no prelo).

LEITÃO-FILHO, H. de F.; PAGANO, S.N.; CÉSAR, O.; TIMONI, J.L.; RUEDA, J.J. Ecologia da Mata Atlântica de Cubatão. Campinas: Ed. Da Universidade Estadual de Campinas/Ed. UNESP, 1993. 184p.

LUKEN, J.O. Directing ecological sucession. London: Chapman and Hall, 1990. $251 \mathrm{p}$.

MANTOVANI, W. Estrutura e dinâmica da floresta atlântica na Juréia, Iguape - SP. São Paulo, 1993. 126p. Tese de Livre Docência - Instituto de Biociências, USP. 
MARTINS, P. da S.; VOLKOFF, B.; CERRI, C.C.; ANDREUX, F. Conseqüências do Cultivo e do Pousio sobre a matéria orgânica do solo sob floresta natural na Amazônia Oriental. Acta Amazônica, v. 20, Mar/dez. 1990.

MARTINS, F.R. Estrutura de uma floresta mesófila. Campinas: Ed. da UNICAMP, 1991. 246p.

McINTOSCH, R.P. Succession and Ecological Theory. In: WEST, D.C.; SHUGART, H.H.; BOTKIN, D.B. Forest Succession: Concepts and application. New York: Springer-Verlag, 1981. Cap. 3, p. 10-23.

MUELLER-DOMBOIS, D.; ELLENBERG, H. Aims and methods of vegetation ecology. New York: J. Wiley \& Sons, 1974. 574p.

ODUM, E.P. Ecologia. Rio de Janeiro: Ed. Guanabara, 1988. 434p.

SHEPHERD, G.J. Manual do FITOPAC 2. Campinas: Depto. de Botânica/IB/UNICAMP, 1987.

THOMAZ, L.D. Florística e Fitossociologia da Floresta Atlântica na Estação Biológica de Santa Lúcia, Santa Tereza - ES. Rio Claro, 1996. 323p. Tese Doutorado, UNESP. 


\section{AS ALTERAÇÕES DOS PARÂMETROS EDÁFICOS NUM SISTEMA AGROFLORESTAL DIRIGIDO PELA SUCESSÃO} NATURAL

\section{RESUMO}

Fabiana Mongeli Peneireiro ${ }^{1}$ Ricardo Ribeiro Rodrigues ${ }^{2}$

A partir de um estudo de caso, comparou-se duas áreas de 0,5 ha cada, uma de sistema agroflorestal (SAF) biodiverso e orientado pela sucessão natural a outra de Capoeira (submetida ao pousio), ambas de mesma idade, mesmo histórico e mesmo tipo de solo, na região de Floresta Ombrófila Densa Sub-montana, no sul da Bahia, Brasil. Procurou-se conhecer os efeitos da implantação e manejo do SAF dirigido pela sucessão natural sobre a fertilidade química do solo e o estoque de nutrientes na serapilheira.

Foram levantados dados relativos à fertilidade do solo (análise química) a partir de 25 amostras compostas, para três profundidades $(0-5,5-20$ e $40-60 \mathrm{~cm})$, oriundas de 75 pontos distribuídos em cada área (SAF e Capoeira - pousio). A serapilheira foi amostrada a partir dos mesmos pontos onde foi realizada amostra do solo, utilizando-se quadrados de $0,25 \mathrm{~m}^{2}$, obtendo-se 25 amostras compostas, que foram enviadas para análise de macronutrientes, $\mathrm{pH}$ e $\mathrm{C} / \mathrm{N}$ (para folhas e tocos). Também realizou-se coleta de macrofauna edáfica (presente na serapilheira e nos primeiros $5 \mathrm{~cm}$ de solo, a partir dos mesmos pontos de coleta de serapilheira e solo.

Com respeito à fertilidade química do solo, o fósforo foi o que mostrou teores mais surpreendentes. Os resultados evidenciaram uma visível melhoria nos teores de fósforo lábil na área de SAF (aproximadamente 7 vezes mais $\mathrm{P}_{2} \mathrm{O}_{5}$, na profundidade de $0-5 \mathrm{~cm}$, e de cerca de 4 vezes, na a profundidade de 5 a $20 \mathrm{~cm}$ ), o que pode ser atribuído ao bombeamento de nutrientes pelas raízes das árvores para as camadas mais superficiais do solo aliado à intensificação da atividade biótica do solo, responsável pela disponibilização dos nutrientes. Os valores médios relativos à V\% e soma de bases (SB) mostraram diferença estatística entre as duas áreas comparadas, para as três profundidades amostradas, sendo que a área de Capoeira apresentou valores aproximados, para a profundidade de $0-5 \mathrm{~cm}$, de $41 \%$ e $73 \mathrm{mmolc} / \mathrm{Kg}$ respectivamente para $\mathrm{V} \%$ e SB, enquanto que os valores encontrados para a área de SAF foram de $83 \%$ e $195 \mathrm{mmolc} / \mathrm{Kg}$. Os valores médios de $\mathrm{pH}\left(\mathrm{em} \mathrm{H}_{2} \mathrm{O}, \mathrm{KCl}\right.$ e CaCl$\left.{ }_{2}\right)$ também mostraram-se distintos para as profundidades de $0-5 \mathrm{~cm}$ e $5-20 \mathrm{~cm}$, sendo por exemplo, os valores de $\mathrm{pH}$ em $\mathrm{CaCl}_{2}$, para a profundidade de 0-5 cm, para a área de Capoeira, de 4,5, enquanto que a área de SAF apresentou 5,4.

Quanto aos resultados relativos à serapilheira, o peso seco de folhas para as duas áreas não apresentou diferença estatística, no entanto, em termos de nutrientes, a área de SAF mostrou teores superiores se comparados com a área em pousio, exceto cálcio e enxofre.

O manejo adotado no SAF foi apontado como sendo o grande responsável pela recuperação do solo degradado, uma vez que promove o avanço sucessional da comunidade e aumenta a oferta de matéria orgânica diferenciada através das podas, possibilitando a dinamização da vida no sistema.

Constatou-se que o SAF em questão transformou área de solo distrófico em uma área produtiva, com alta fertilidade, em 12 anos de manejo, mostrando-se como uma alternativa promissora para a recuperação de solos degradados, além de se constituir num sistema de produção sustentável para os trópicos úmidos, sem a utilização de insumos externos.

\footnotetext{
${ }^{1}$ Engenheira Agrônoma, mestranda em Ciências Florestais, ESALQ/USP.

${ }^{2}$ Prof. Dr. Depto. Ciências Biológicas, ESALQ/USP.
} 


\section{IV.1. INTRODUÇĀO}

"Os nutrientes do solo estão entre os menos resilientes componentes da sustentabilidade" (Fresco \& Kroonemberg, 1992, apud Sanchez, 1995). O manejo equivocado dos solos em condições de agricultura tem levado os mesmos à degradação, com conseqüente redução da sua fertilidade (devido à destruição da matéria orgânica, eliminação da biota, lixiviação dos nutrientes e erosão condicionada pela desagregação e compactação do solo).

A pobreza de nutrientes é freqüentemente um fator limitante crucial em áreas de florestas tropicais pluviais (Lopes et al., 1985); mas a presença da floresta modifica este panorama pois as árvores desenvolveram mecanismos de conservação de nutrientes, que permitem a sua permanência e crescimento, apesar da pobreza de nutrientes no solo. A maioria dos mecanismos do sistema (relativos à adaptações das plantas e às interrelações entre plantas, organismos, matéria orgânica e solo) propiciam uma transferência muito eficiente de nutrientes da matéria orgânica para as raízes das árvores em desenvolvimento, através da decomposição de matéria orgânica do solo e da serapilheira (Golley et al., 1978; Jordam \& Herrera, 1981 apud Lopes et al., 1985). Uma vez os nutrientes incorporados nos tecidos dos organismos da comunidade do solo não podem ser facilmente perdidos pela lixiviação, volatilização ou reação com ferro e alumínio, no caso do fósforo, sendo esta uma estratégia importante que propicia ecossistemas abundantes em vida sobre condições aparentemente de baixa fertilidade. Isso sugere que a melhor abordagem efetiva para o manejo de áreas originariamente ocupadas com florestas tropicais seria adotar sistemas que mantenham, o máximo possível, a estrutura florestal, pois a comunidade do solo depende diretamente de um "input" constante de matéria orgânica (Jordan, 1990).

Assim, o ecossistema floresta, com todo o seu vigor e complexidade em formas de vida desenvolveu estratégias para interagir com os demais fatores do ambiente (climáticos, edáficos, etc.), de forma a possibilitar a máxima quantidade e qualidade de vida consolidada (Götsch, 1995) para aquela condição, contradizendo a idéia tão difundida de que, a maioria dos solos tropicais possui baixa fertilidade. Ou seja, a 
fertilidade de tais solos é considerada baixa dentro de uma análise estática e reducionista, pois é justamente na dinâmica das interações entre os seres vivos e os fatores abióticos que permitem as condições para a manutenção da vida nesses tipos de ecossistemas caracterizados pela elevada diversidade.

As hipóteses a respeito das relações solo/árvore para solos de baixa fertilidade dos trópicos úmidos têm sido muito discutidas na bibliografia, principalmente, sob os conceitos de proteção da superfície do solo, ciclagem de nutrientes e adição de nutrientes. Estudando quatro opções de SAF que parecem ser adequadas para solos ácidos dos trópicos úmidos da América Latina e Caribe, Benites (1990) concluiu que os sistemas agroflorestais sempre devem ser particulares e específicos para uma determinada condição, e por isso a pesquisa deverá principalmente indicar princípios que vão em direção a essa especificidade.

Convencionalmente, árvores tem sido vistas como capazes de melhorar a ciclagem dos nutrientes e retenção dos mesmos nos ecossistemas agrícolas (Buresh, 1994 apud Garrity et al., 1994). Entre os benefícios relevantes para a ciclagem dos nutrientes e manutenção da matéria orgânica (Joung, 1989), estão: i) bombeamento de nutrientes do subsolo pelas raízes profundas das espécies perenes; ii) redução nas perdas por lixiviação através da captura de nutrientes móveis pelos sistemas radiculares bem desenvolvidos das espécies perenes; iii) adição de nitrogênio através da fixação biológica de $\mathrm{N}$ pelas perenes; iv) manutenção da matéria orgânica do solo através do suprimento pelo "litter" abaixo e acima do chão e podas das perenes; v) manutenção e melhoria das propriedades físicas do solo e vi) aumento da proteção do solo contra erosão. Porém ainda há poucas evidências concretas e muito poucos dados que confirmem essas hipóteses, principalmente porque para prová-las adequadamente, são necessários experimentos que comparem um sistema agroflorestal com um sistema não agroflorestal (Paniagua et al., 1994).

Em sistemas mistos de espécies perenes e anuais, as árvores podem se comportar como uma rede de segurança de nutrientes, reduzindo as perdas e reciclando os nutrientes recapturados (Van Noodwijk and de Willegen, 1991 apud Garrity et al., 1994). Quintais tropicais e SAFs complexos freqüentemente se parecem com sistemas 
de florestas secundárias na estrutura e ecologia. $\mathrm{Na}$ revisão de indicadores de sustentabilidade de quintais tropicais de Torquebiau (1992) foram encontradas muitas fontes indiretas de evidências de que os níveis de fertilidade do solo são mantidos, nesses casos, por longos períodos (Garrity et al., 1994).

As pesquisas relativas a solos sob sistemas agroflorestais nos trópicos úmidos ainda são muito incipientes e há necessidade de se conhecer melhor sobre os processos envolvidos na dinâmica dos nutrientes e da matéria orgânica nesses solos, já que afetam a sustentabilidade e performance dos SAFs, assim como compreender melhor as relações solo/árvore, pois as informações que se tem hoje, muitas vezes se apoiam em evidências indiretas e esparsas (Benites, 1990; Szott et al., 1991; Garrity et al., 1994).

Nesse sentido, há um grande potencial inexplorado dos SAFs, principalmente relacionado aos componentes lenhosos, de como estes poderiam ser escolhidos ou manejados para interferir sobre a transformação do estoque de matéria orgânica dos solos conservando ou recuperando a fertilidade e conseqüentemente definindo a produtividade dos sistemas (Szott et al., 1991).

Os sistemas agroflorestais que têm como uma das práticas de manejo a poda das espécies componentes, permite um aporte regular de matéria orgânica. Mas a poda de espécies arbóreas em sistemas agroflorestais não têm apenas essa função, uma vez que além de rejuvenescer o sistema, pode contribuir para o aumento de volume de solo explorado pelas raízes, pois leva a rebrotação de novas raízes secundárias (Copes, 1992). Apesar dos poucos dados sobre os efeitos da poda no sistema radicular constatou-se que após a poda, há crescente mortalidade de raízes finas ( $<2 \mathrm{~mm}$ de diâmetro), que rapidamente se regeneram (Fernandes, 1990 apud Szott et al., 1991). A poda, como técnica de manejo para acelerar fluxos de nutrientes, principalmente em solos de baixa fertilidade, parece ser promissora para aumentar a produtividade das plantas (Szott et al., 1991).

A produção de serapilheira, decomposição, e dinâmica da matéria orgânica do solo são processos-chave que afetam a fertilidade do solo e a sustentabilidade dos sistemas florestais baseados no não uso ou uso limitado de "inputs" químicos, mas poucos dados existem quanto a influência da quantidade, qualidade, momento de manejo 
e papel da matéria orgânica sobre esses processos. Falta especialmente conhecimento sobre produção de "litter" e decomposição da matéria orgânica sob o solo, de modo que é necessário muito trabalho de pesquisa a respeito dos processos que regulam a disponibilização de nutrientes dessas fontes de matéria orgânica no sistema (Szott et al., 1991). Outra questão considerada prioritária na pesquisa atual diz respeito à sincronia de demanda de nutrientes pelas plantas com a disponibilidade de nutrientes do "litter" e poda das árvores (Garrity et al., 1994).

Informações sobre interações entre os organismos, o solo e a matéria orgânica são escassas e dispersas (Lavelle, 1996). Devido à abordagem reducionista da pesquisa e à divisão da ciência do solo em várias subdisciplinas, pouco ainda é conhecido das interações entre organismos do solo e os efeitos resultantes disto na diversidade das comunidades e processos do solo sobre diferentes escalas espaço-temporais (Lavelle, 1987apud Brown, 1995). Sistemas de baixo "input" podem contribuir com condições favoráveis à fauna do solo, a qual responde positivamente, acarretando uma influência positiva na fertilidade do solo e produtividade, embora evidências sejam escassas (Curry $\&$ Good, 1992).

A biota do solo, ao agir sobre a matéria orgânica (fonte de energia e nutrientes), vai transformando e criando uma ambiente extremamente propício à vida das plantas, ao incorporar a matéria orgânica no solo e liberar nutrientes (Lopes et al., 1985; Hendrix et al., 1990), o que sugere que certamente a fertilidade do solo é em grande parte um fenômeno biológico.

Com o intuito de contribuir para a demanda de conhecimento sobre SAFs e a fim de compreender quanto e como a implantação e manejo do SAF dirigidos pela sucessão natural interferem sobre os parâmetros edáficos, efetuou-se, nas duas áreas (SAF manejado a 12 anos e Capoeira, em pousio há 12 anos):

i. análise química do solo;

ii. análise química da serapilheira (reservatório de nutrientes);

iii. levantamento da macrofauna edáfica (presente na serapilheira e nos primeiros $5 \mathrm{~cm}$ do perfil do solo). 


\section{IV.2. CARACTERIZAÇÃO DAS ÁREAS DE ESTUDO}

A propriedade Três Colinas, do agricultor-pesquisador Ernst Götsch, onde foi realizado este estudo de caso, está localizada na região sul da Bahia, entre as cidades de Gandu e Ituberá, na longitude $39^{\circ} 17^{\prime} 08^{\prime}$ 'W e latitude $13^{\circ} 44^{\prime} 45^{\prime} \mathrm{S}$, a uma altitude de $350 \mathrm{~m}$. O relevo local é fortemente ondulado, apresentando solos latossólicos e podzólicos argilosos com alto grau de intemperização, profundos, ricos em óxidos de ferro e alumínio, considerados pouco férteis, derivados de rochas gnaissicas e graníticas do planalto cristalino, do período Pré-Cambriano.

O clima da região é quente e úmido, sendo que a pluviosidade média é de 1500 $\mathrm{mm}$ bem distribuídos no ano, apresentando uma leve estiagem no verão (dezembro a fevereiro) e uma maior concentração de chuvas no inverno (junho a agosto).

A vegetação regional está classificada como Floresta Ombrófila Densa (FIBGE, 1992) ou Floresta Atlântica "sensu stricto", que vem sofrendo intenso desmatamento, seja pela retirada da vegetação original em sua íntegra, seja por sua intensa exploração, visando exportação de madeira ou mesmo abertura para a prática agrícola (SANTANA, 1990).

Quanto ao histórico, ambas as áreas de estudo sofreram exploração de madeira e queima e foi usada para roças de mandioca (Manihot sculenta Crantz.) sucessivas, até o esgotamento do solo, tendo então sido transformada em pasto e posteriormente abandonadas. Procedeu-se nesse trabalho uma comparação entre uma área em pousio (A0 - Capoeira), que foi tida como referência, com a área de SAF (A12), manejada. A área A0 apresentava uma vegetação resultante da regeneração natural, com manchas heterogêneas, principalmente de sapé (Imperata cilindrica), feto-de-gaiola (Pteridium aquillinum) (L.) Kunn) e espécies "de terra fraca”, principalmente herbáceas da família Asteraceae e arbóreas da família Melastomataceae, que ocuparam a área durante o tempo em que esta ficou em pousio.

Enquanto esse trecho ( $\mathrm{A} 0$ ) estava submetido à regeneração natural pelo processo de pousio, outro trecho vizinhb, definido como A12, há 12 dłblos atrás, foi submetida ao manejo: procedeu-se roçada e retirada da pouca madeira quté H睛ia na área, adicionou- 
se, a lanço, $2400 \mathrm{Kg}$ calcário/ha e introduziu-se um sistema agroflorestal. Além da introdução de espécies de interesse econômico, a regeneração natural foi sendo conduzida por meio de capinas seletivas e podas, no sentido do avanço da sucessão natural. O manejo dessa área (A12) consistia em duas podas/ano até 1992, e uma poda/ano de 1992 em diante.

Nesse manejo, realizou-se podas de até $70 \%$ das copas dos indivíduos arbóreos da área. A última deu-se em outubro de 1996.

As principais culturas produzidas na área A12 (SAF) foram abacaxi, banana e cacau, sendo que a banana produziu bem por quatro anos (média de 618,7 cachos de 10 $\mathrm{Kg} /$ ha.ano), tendo declinado paulatinamente nos anos posteriores e o cacau, aos dez anos produziu (num ano considerado um fraco para a agricultura) uma média de 50 @/ha, valor esse que apresenta $14 @$ acima da média do sul da Bahia.

A decisão para implantação de um SAF foi em função dessa região aparentar condições ambientais desfavoráveis para a produção do cacau (Theobroma cacao L.), que é uma espécie mais avançada na sucessão (mais exigente em termos de fertilidade do solo, Alvim \& Koslowski, 1977) que atuaria como indicadora da qualidade de seu trabalho de manejo na recuperação da área.

Informações detalhadas a respeito dos conceitos que fundamentam os SAFs dirigidos pela sucessão natural e o manejo dos SAFs podem ser encontrados em Götsch (1995) e no Capítulo V.

\section{IV.3. METODOLOGIA}

Primeiramente procedeu-se a escolha das áreas de estudo por meio de tradagens e avaliação de características pedológicas, tais como: textura, cor, pedregosidade, etc. Ao serem escolhidas as áreas mais semelhantes foram abertas trincheiras nas duas áreas, onde foram realizadas caracterização morfológica e amostragems para análises químicas e físicas dos horizontes, para identificação do solo e avaliação quanto à possibilidade de comparação entre as duas áreas, ou seja, se ambas apresentavam o mesmo tipo de solo. 
Com a confirmação da semelhança dos solos, foram demarcadas duas áreas, de 0,5 ha cada, área A0 - Capoeira em pousio e A12 - Sistema Agroflorestal.

Tanto para a $\mathrm{A} 0$ quanto para a $\mathrm{A} 12$, para análise química do solo foram obtidas 25 amostras compostas, para as três profundidades $(0$ a $5 \mathrm{~cm}$, de 5 a $20 \mathrm{~cm}$ e de 40 a 60 $\mathrm{cm}$ ), a partir de 75 pontos, distribuídos sistematicamente por toda a área (de acordo com o croqui). Para cada profundidade, as amostras de três pontos seqüenciais eram homogeneamente misturadas e então obtida uma amostra composta.

As amostras de solo foram então encaminhadas para análises no laboratório do Departamento de Solo da ESALQ/USP, onde foram identificados os seguintes parâmetros: pH em $\mathrm{H} 2 \mathrm{O}, \mathrm{KCl}$ e $\mathrm{CaCl} 2, \mathrm{M} . \mathrm{O}, \mathrm{P}, \mathrm{K}, \mathrm{Mg}$, Ca, S-SO4, Al, H+Al; SB, T, $\mathrm{V} \%$ e $\mathrm{m} \%$.

A serapilheira foi amostrada a partir dos mesmos pontos onde foi realizada amostra do solo, nas duas áreas comparadas (A0 e A12) utilizando-se quadrados de 0,25 $\mathrm{m}^{2}$ (Golley et al., 1978; Santana et al., 1990; Gabriel, 1997), obtendo-se 25 amostras compostas.

Para o encaminhamento das amostras de serapilheira ao laboratório foi necessário um preparo preliminar, separando-se as folhas do material lenhoso, de modo que tocos e folhas fossem analisados separadamente. Cada amostra foi pesada depois de ter sido seca ao ar para que, depois de calculada a porcentagem de umidade, fosse possível obter uma estimativa do peso seco de serapilheira por hectare para as duas áreas. Após a pesagem efetuou-se trituração de cada amostra em moinho, e a sua homogeneização. Uma sub-amostra de cada amostra foi separada e enviada ao laboratório para análise química. Os resíduos foram secos a $110^{\circ} \mathrm{C}$ e foram obtidos valores de porcentagem de umidade, porcentagem dos nutrientes ( $\mathrm{N}, \mathrm{P}, \mathrm{K}, \mathrm{Ca}, \mathrm{Mg}, \mathrm{S}$ ), além de valores referentes a $\mathrm{pH}$ e relação $\mathrm{C} / \mathrm{N}$. Os dados referentes aos teores de nutrientes foram convertidos em peso referente à massa amostrada, possibilitando o cálculo de peso total de serapilheira por hectare e dos teores de cada nutriente por hectare $(\mathrm{em} \mathrm{Kg})$.

Também foi realizado levantamento da macrofauna edáfica (presente na serapilheira e nos primeiros $5 \mathrm{~cm}$ do solo). Para a coleta da macrofauna ( $>2 \mathrm{~mm}$, exceto 
formigas e cupins) presente nos mesmos 75 pontos de coleta de solo e serapilheira de cada área (A12 e A0), utilizou-se o método da captura manual, no momento da coleta da serapilheira e logo em seguida, ao desagregar o solo para a coleta da amostra da profundidade de $0-5 \mathrm{~cm}$. Efetuou-se uma triagem grosseira, em cada ponto de amostragem, sendo os representantes da macrofauna reunidos em uma única amostra para cada área estudada (A12 - SAF e A0 - Capoeira) e armazenados em álcool a 70\%. A identificação foi feita por especialistas. Além dos indivíduos coletados, atenção especial foi dirigida para os vestígios da ação da macrofauna no solo, como presença ou ausência de galerias, coprólitos e ninhos.

\section{IV.4. RESULTADOS E DISCUSSĀO}

\section{IV.4.1. SOLOS}

A análise dos perfis das trincheiras nas duas áreas (A12 e A0) possibilitou a identificação do solo e mostrou que trata-se do mesmo para as duas áreas (pode-se afirmar isso a partir, principalmente das análises morfológicas e físicas de extrema semelhança para as duas situações, assim como as análises químicas em profundidade (de acordo com ANEXOS C, D e E).

O solo do caso estudado, situado sob a vegetação original Floresta Umbrófila Densa, trata-se de um Latossolo Amarelo Podzólico Distrófico ou um Oxisol, o qual é caracterizado por ser extremamente profundo, intemperizado e lixiviado, rico em sesquióxidos de ferro e alumínio na fração argila, com baixa capacidade de troca de bases, baixa atividade da argila, baixos conteúdos de minerais primários, sendo geralmente ácidos e pobres em nutrientes (Young, 1976; Jordan, 1990).

Os ANEXOS L e M apresentam os resultados da análise química do solo das duas áreas (A0 e A12).

Apesar das quantidades de matéria orgânica não diferirem entre as áreas (Figura IV.1, ANEXOS L e N), os dados referentes aos teores de nutrientes (exceto para o S$\mathrm{SO}_{4} \mathrm{e} \mathrm{K}$ ) apresentaram diferenças significativas entre as áreas $\mathrm{A} 12$ e A0, principalmente 
para as camadas superficiais $(0-5$ e $5-20 \mathrm{~cm})$. Isso nos leva à reflexão de que as diferenças estão relacionadas à qualidade da matéria orgânica proveniente da serapilheira e sua dinâmica de decomposição (conseqüência da atividade da biota do solo) (Golley et al., 1978; Primavesi, 1980; Haag et al., 1985; Szott et al., 1991; Gabriel, 1997). Essa atividade resultaria em matéria orgânica estável (húmus), com conseqüente liberação de nutrientes. Assim, o processo dinâmico de transformação envolvido na ciclagem dos nutrientes é uma possível explicação para as diferenças constatadas para os outros parâmetros de fertilidade do solo entre as áreas estudadas, que não foi expressa na quantidade de matéria orgânica.

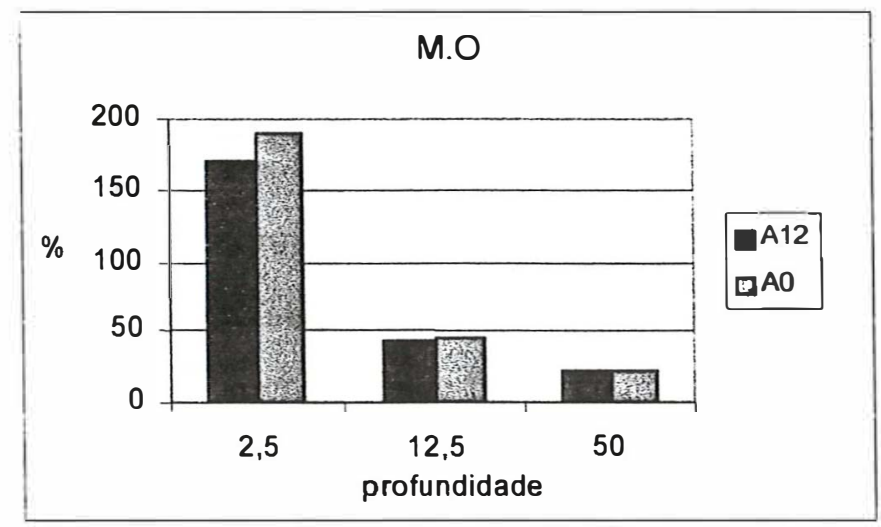

Figura IV.1 - Teores de matéria orgânica (\%) para as três profundidades amostradas (05, 5-20 e 40-60 cm), para as duas áreas estudadas (A12 - SAF e A0 Capoeira), município de Ituberá, Bahia, Brasil.

"A matéria orgânica serve como uma reserva de nutrientes a partir da qual eles são lentamente liberados para a solução do solo e tornam-se disponíveis para as plantas. Além disso, sua presença no solo ou sobre ele protege-o e ajuda a regular sua temperatura e umidade" (Reyintyes et al., 1994). Experimentos com técnicas de manejo da terra que conservam mais a matéria orgânica no sistema vêm se tornando cada vez mais freqüentes a partir da compreensão de que a conservação da matéria orgânica do solo e da serapilheira pode ser extremamente importante para a fertilidade dos solos tropicais (Jordan, 1990). 
Para os valores de $\mathrm{pH}$ (Figura IV.2) obteve-se diferença estatística entre as áreas para as camadas superficiais e não para a camada mais profunda, comportamento que, aliás, se repetiu para a maioria dos dados, mostrando que as diferenças são resultantes do uso diferenciado do solo, que se expressa mais na camada superficial do solo, onde está localizada a maioria das raízes finas das plantas (Garrity et al., 1994) e onde ocorre o processo de decomposição da serapilheira e de absorção da maior parte dos nutrientes disponibilizados. Esses resultados reforçam ainda que os solos são iguais na origem.
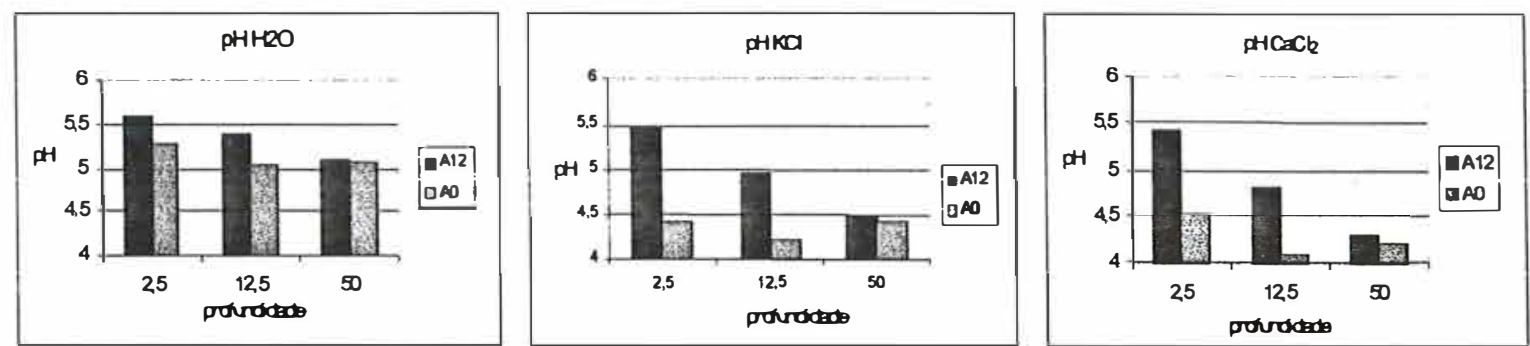

Figura IV.2 - Valores de $\mathrm{pH}\left(\mathrm{em} \mathrm{H}_{2} \mathrm{O}, \mathrm{KCl}\right.$ e $\left.\mathrm{CaCl}_{2}\right)$, nas três profundidades amostradas (0-5, 5-20 e 40-60 cm), para as duas áreas estudadas (A12 - SAF e A0 Capoeira), município de Ituberá, Bahia, Brasil.

Os teores de potássio $(\mathrm{K})$ e enxofre $\left(\mathrm{SO}_{4}\right)$ não mostraram diferença significativa entre as duas áreas (ANEXO N).

Os teores dos elementos cálcio e magnésio mostraram-se estatisticamente diferentes entre as duas áreas estudadas (ANEXO N). A Figura IV.3 ilustra a amplitude de variação desses elementos nessas áreas (A12 e A0), principalmente nas camadas superficiais do solo, novamente apontando que a distribuição e os teores dos nutrientes está diretamente condicionada com a atividade da biota na superficie do solo, que atuam na decomposição da serapilheira. Apesar de ser praticamente improvável que ainda haja efeito residual da calagem realizada há 12 anos atrás, principalmente no $\mathrm{pH}^{7}$, houve um incremento inicial de $\mathrm{Ca}$ e $\mathrm{Mg}$ no sistema, a partir da introdução do calcário na área A12, incremento esse que passou a fazer parte da ciclagem biogeoquímica do sistema. 

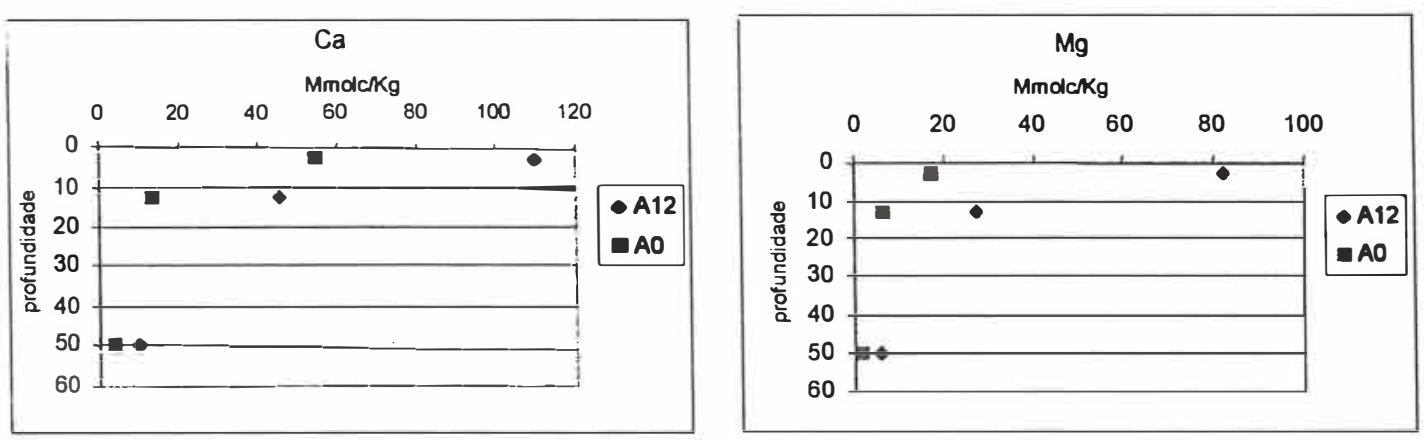

Figura IV.3 - Teores de cálcio e magnésio nas três profundidades amostradas (0-5, 5-20 e 40-60 cm), para as duas áreas estudadas (A12 - SAF e A0 - Capoeira), município de Ituberá, Bahia, Brasil.

O elemento que teve a variação mais surpreendente entre as duas áreas foi o fósforo, cujos teores na A12 apresentaram-se aproximadamente 7 vezes maior na camada de 0 a $5 \mathrm{~cm}$, e cerca de 4 vezes maior na camada de 5 a $20 \mathrm{~cm}$, quando comparados com os teores da A0, e na camada de $40-60 \mathrm{~cm}$, foram muito semelhantes (Figura IV.4).

O baixo nível de $\mathrm{P}$ disponível é considerado o fator limitante mais comum para o crescimento das plantas nos ambientes tropicais úmidos (Lombardi, 1981 apud Lopes et al., 1985; Sanchez, 1976, Fox and Searle, 1978, Uehara and Gillman, 1981, apud Jordan, 1990), principalmente em Oxisols e Andisols, em função do elevado grau de fixação desse elemento (Szott et al., 1991; Young, 1976).

${ }^{3}$ MALAVOLTA, comunicação pessoal, 1998. 


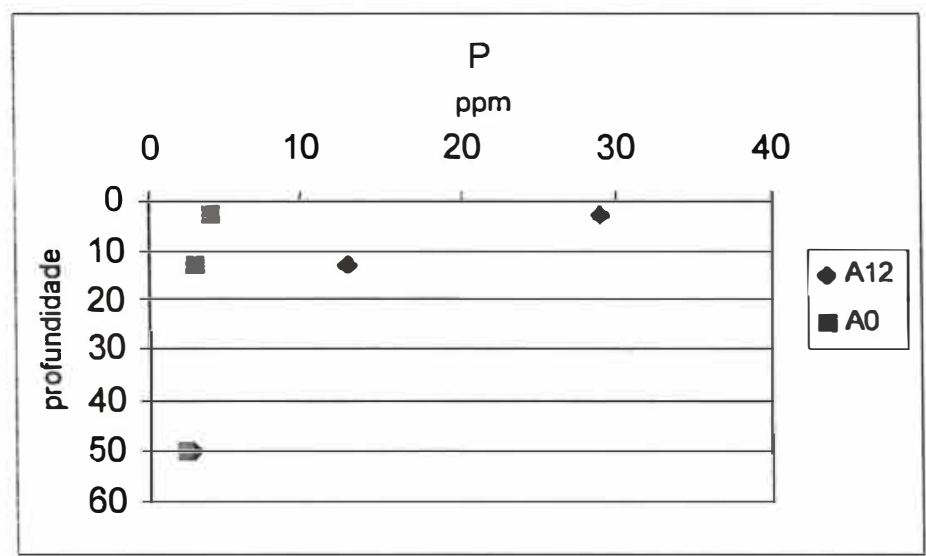

Figura IV.4 - Teores de fósforo (P) nas três profundidades amostradas (0-5, 5-20 e 40$60 \mathrm{~cm}$ ), para as duas áreas estudadas (A12 - SAF e A0 - Capoeira), município de Ituberá, Bahia, Brasil.

Apesar de não ter sido adicionada nenhuma fonte de fósforo nas áreas estudadas, os teores apresentaram-se muito distintos entre as áreas A12 e A0 nas camadas superficiais. Como se trata do mesmo solo, com mesmo histórico de uso no passado (mais de 12 anos) e com valores semelhantes de fósforo nas camadas mais profundas, e pelo fato de não ter sido acrescentada fonte de fósforo na área A12, a explicação para os altos teores de fósforo disponível nas camadas superficiais do solo da área A12 deve estar relacionada com a dinâmica desse elemento no solo e seus condicionantes, como apontada na análise de fósforo total dessas áreas (Tabela IV.1):

TABELA IV.1: Teores de fósforo total nas três profundidades amostradas, para as duas áreas estudadas (A12 - SAF e A0 - Capoeira), município de Ituberá, Bahia, Brasil, obtidos a partir de extração com $\mathrm{HCl}$ 1+1:

\begin{tabular}{lcc}
\hline & \multicolumn{2}{c}{$\mathrm{P}_{2} 0_{5}$ total \% } \\
\hline Profundidade $(\mathbf{c m})$ & $\mathbf{A 0}$ & $\mathbf{A 1 2}$ \\
\hline $0-5$ & 0.06 & 0.13 \\
$5-20$ & 0.03 & 0.08 \\
$40-60$ & 0.12 & 0.05 \\
\hline
\end{tabular}


Esses resultados dos teores de fósforo podem estar diretamente relacionados com a dinâmica da matéria orgânica no sistema pois sabe-se que a preservação da matéria orgânica pode aumentar a fração de $\mathrm{P}$ lábil no solo acima da quantidade atribuída à mineralização de P na matéria orgânica (Jordan, 1990).

A manutenção de um alto teor de matéria orgânica é muito importante para a dinâmica do fósforo, por tratar-se de uma fonte contínua de fósforo aravés da mineralização, pelo fato dos fosfatos orgânicos serem menos fortemente fixados do que as formas inorgânicas (Garrity et al., 1994; Shang et al., 1992) e pelo fato dos ácidos orgânicos dissolverem algum fosfato 'fixado', tornando-o disponível (Young, 1976).

Os altos teores de fósforo lábil obtidos na área de SAF (A12) podem ser resultado da atuação dos ácidos orgânicos liberados durante a decomposição da matéria orgânica como responsáveis pela solubilização de fosfatos complexados pelo $\mathrm{Fe} \mathrm{e} \mathrm{Al}$ (Jordan, 1990). A ocorrência natural de compostos orgânicos (por exemplo, certos oxalatos) no solo também podem ser importantes nesse processo, já que promovem a quelatação do $\mathrm{Fe}$, reduzindo a disponibilidade desse elemento para reagir com o fósforo (Jordan, 1990). Outra possível explicação para os altos níveis de fósforo solúvel é que os nutrientes e o carbono lixiviados da matéria orgânica em decomposição estimulam o crescimento microbiano, cujas atividades ou produtos de seu metabolismo podem desempenhar um papel importante na solubilização de fosfato, tanto através da produção de fosfato e quebra de húmus recalcitrante na fração mineral do solo, como através de ácidos orgânicos que solubilizam o fósforo retido inorganicamente (Jordan, 1990).

O papel dos microorganismos é fundamental na nutrição fosfatada, mineralizando as reservas de fósforo orgânico, dissolvendo fontes insolúveis de fosfatos inorgânicos e captando fósforo solúvel em regiões não alcançadas pelas raízes, transferindo-o para as plantas, bem como imobilizando o fósforo do solo no seu próprio protoplasma celular, tornando-o indisponível às plantas ou à sua fixação pelo ferro, cálcio e alumínio (Lopes et al., 1985).

Se comprovado que a matéria orgânica no solo desempenha um papel importante na "solubilização" do P fixado pelo Al ou pelas argilas minerais (Jordan, 1990), estes resultados têm importantes implicações para o manejo da terra para sistemas de 
produção nos trópicos úmidos, onde as práticas atuais de agricultura praticamente desprezam a matéria orgânica.

Resultados de estudos com fósforo marcado $\left(\mathrm{P}^{32}\right)$ sobre cacau, café, e banana mostram que uma grande proporção do bombeamento do $\mathrm{P}$ (30 a 85\%) originou-se da zona superficial do solo (IAEA 1975 apud Garrity et al., 1994).

Lima (1994) encontrou maiores teores de fósforo no subsistema CMQ (Cultivos Mistos de Quintal - Sistema Agroflorestais da Várzea Amazônica) em relação à roça o que, segundo ele, confirma a capacidade deste subsistema de manter a fertilidade do solo com baixa exportação dos nutrientes, condicionada pela manutenção de uma estrutura multiestratificada e pelo tipo de manejo que permite a formação de uma densa camada de matéria orgânica na superfície do solo.

Sugere-se que as árvores, por apresentarem sistema radicular mais profundo que as culturas anuais, absorvam quantidades significativas de nutrientes do subsolo, que são depositadas sobre a superficie do solo via "litter", poda ou morte das raízes superficiais (Glover \& Beer, 1986; Young, 1989; Garrity et al., 1994). Este processo de translocação aumenta o estoque de nutrientes disponíveis para as raízes superficiais das culturas anuais que crescem em associação, aumentando assim a produção do sistema. Buresh, (1994) apud Garrity et al. (1994) salienta que esta função do "bombeamento de nutrientes" pelas raízes de espécies arbóreas atualmente é citada com freqüência, como sendo um benefício dos SAFs. O processo seria particularmente para fornecer e conservar os nutrientes relativamente imóveis, como $\mathrm{P}$, na superfície do solo.

Um fator interessante é que as raízes são capazes de converter formas recalcitrantes de $\mathrm{P}$ em formas capazes de serem absorvidas, e assim aumentar o reservatório de P exportável (Garrity et al., 1994).

$\mathrm{O}$ alto teor de fósforo solúvel encontrado na camada superficial do solo da área manejada (A12) pode ser explicado, portanto, pela atuação conjunta do bombeamento de nutrientes pelas raízes das árvores das camadas mais profundas do solo para a superficie, potencializado pela poda dos indivíduos arbóreos, como prática característica desse sistema, e pela dinamização da atuação da biota do solo para a disponibilização de 
nutrientes, em função do incremento periódico de matéria orgânica de qualidade diferenciada resultante da prática da poda.

A poda das árvores em aléias e em sistemas de produção frutíferas/árvores de sombra aumentou o fluxo de nutrientes se comparado com floresta natural, presumivelmente por causa da falta de retranslocação dos nutrientes do tecido antes da poda (Szott et al., 1991). Esse material proveniente da poda, diferenciado em termos de nutrientes, é consumido pela biota do solo, que disponibiliza os nutrientes adsorvidos no solo, especialmente fósforo depois de passar pelo trato digestivo das minhocas (Lavelle, 1997). Por exemplo, tem-se reportado um grande aumento na atividade de fosfatase nos coprólitos frescos de minhocas (Martin \& Marinissen, 1993), provavelmente conseqüência da alta atividade dos microorganismos no rico meio de cultura que são esses dejetos.

No SAF dirigido pela sucessão natural houve um aumento significativo de fósforo nas camadas superficiais, o que não foi verificado em sistema de aléias, "pouco diversos", mesmo que tenham a poda como prática de manejo, como mencionou Garrity et al. (1994).

Os valores médios relativos à soma de bases (SB) e V\% mostraram diferença estatística entre as duas áreas comparadas (ANEXO N), para as três profundidades amostradas, sendo que a área de Capoeira apresentou valores aproximados, para a profundidade de $0-5 \mathrm{~cm}$, de $41 \%$ e 73 mmolc respectivamente para V\% e SB, enquanto que os valores encontrados para a área de SAF foram de $83 \%$ e $195 \mathrm{mmolc} / \mathrm{Kg}$. Esses altos valores encontrados para a área de SAF (A12) são conseqüência da adição de cálcio e magnésio pela calagem e também da ciclagem biogeoquímica intensa proporcionada pela prática de manejo.

\section{IV.4.2. MACROFAUNA EDÁFICA}

A amostragem da macrofauna foi considerada adequada ${ }^{8}$ para dar uma idéia dos tipos de vida presentes na macrofauna edáfica, para as duas áreas estudadas,

\footnotetext{
${ }^{8}$ Comunicação pessoal com Prof. LAVELLE, 1998.
} 
principalmente no que se refere aos animais mais lentos e de maior porte (como os diplópodas, minhocas, aranhas e quilópodas, por exemplo).

Apesar de ter sido considerado um procedimento superficial e pouco acurado, procurou-se, com os dados qualitativos a respeito da macrofauna (formas de vida e sua função) delinear tendências para as duas áreas e enriquecer a discussão sobre a fertilidade química do solo, já que está diretamente relacionada com a atividade da biota.

De acordo com a Tabela IV.2, pode-se observar a predominância de espécies predadoras na área de capoeira $(\mathrm{A} 0)$ e de espécies saprófagas na área manejada (A12). A área manejada (A12) pode ser encaixada no estágio 5 da sucessão da fauna do solo, mostrando-se mais adiantada do que a A0 (Capoeira), que seria encaixada nos estágios 2 e 3 (Curry \& Good, 1992), coincidindo com os parâmetros vegetacionais.

TABELA IV.2: Principais formas de vida da macrofauna edáfica encontradas nas duas áreas estudadas (A12 - SAF e A0 - Capoeira), com respectivos números de indivíduos encontrados; município de Ituberá, Bahia, Brasil.

\begin{tabular}{lccc}
\hline & SAF (Al2) & Capoeira (A0) & Guilda \\
\hline $\begin{array}{l}\text { Minhocuçu * } \\
\text { Rhinodrillus sp. }\end{array}$ & 4 & 0 & Saprófago \\
$\begin{array}{l}\text { Minhocas: } \\
\text { Pheretima hawaiana }\end{array}$ & 9 & & Saprófago \\
Pontoscolex coretrurus & 54 & 201 & \\
Diplópodas & $46(5$ pequenos $)$ & $34(22$ pequenos $)$ & Saprófago \\
Chilópodas & 7 & 28 & Predador \\
Aracnida & 11 & 78 & Predador \\
\hline
\end{tabular}

Embora minhocuçus não tenham sido coletados durante as amostragens, evidências da atividade desse animal foram intensamente encontradas na A12, como grandes coprólitos (ANEXO O) em 71 dos 75 pontos de amostragem de solo. Não foram encontrados coprólitos de minhocuçu na área de Capoeira (A0), embora muitos coprólitos granulares pequenos eram, muitas vezes, abundantes na superfìcie do solo.

Para fins ilustrativos, esses coprólitos foram analisados quimicamente (Tabela IV.3), mostrando alta qualidade quanto aos parâmetros relativos à fertilidade, o que 
reitera as afirmações de que a biota do solo tem papel fundamental na dinamização da ciclagem de nutrientes, interferindo assim nas características do solo e causando grande mudança no crescimento das plantas (Lavelle 1996 E 1997; Martin \& Marinissen, 1993; Lopes et al. 1995; Young, 1976; Hamilton \& Sillman, 1989; Kang et al., 1994; Brown, 1995).

TABELA IV.3: Análise de coprólito de minhocuçu encontrado na área manejada com SAF (A12), município de Ituberá, Bahia, Brasil.

\begin{tabular}{lc}
\hline \multicolumn{1}{c}{ Parâmetros } & Valores \\
\hline $\mathrm{pH} \mathrm{CaCl}$ & \\
Umidade total & 6.6 \\
Matéria orgânica total & $49.83 \%$ \\
Carbono orgânico & $23.44 \%$ \\
Nitrogênio total & $12.56 \%$ \\
Fósforo $\left(\mathrm{P}_{2} \mathrm{O}_{5}\right)$ total & $0.64 \%$ \\
Potássio $\left(\mathrm{K}_{2} \mathrm{O}\right)$ total & $0.18 \%$ \\
Cálcio total & $0.28 \%$ \\
Magnésio total & $0.58 \%$ \\
Enxofre total & $0.20 \%$ \\
Relação C/N & $0.14 \%$ \\
\hline
\end{tabular}

Minhocas têm sido o foco de pesquisas recentes, pois elas contribuem para a decomposição da serapilheira e disponibilização de nutrientes através da ingestão e mistura de resíduos de plantas com o solo. A atividade de descarte (produção de coprólitos) das minhocas varia com a espécie e com as condições ambientais locais, particularmente com a cobertura vegetal (Kang et al., 1994).

Os efeitos das minhocas sobre o crescimento das plantas tem sido bem documentados, especialmente em experimentos de curto-prazo em vasos. Os mecanismos pelos quais as minhocas estimulam o crescimento das plantas ainda não está claro. Os fatores provavelmente envolvidos são: i) mobilização de nutrientes que normalmente não estaria disponível (fósforo adsorvido e nutrientes contidos nas frações orgânicas resistentes; ii) trocas favoráveis de água e oxigênio para suprir as raízes; iii) uso mais eficiente dos nutrientes baseado numa sincronização e justaposição de 
liberação de nutrientes e nutrientes absorvidos pelas plantas; e iv) um efeito "tipo hormônio" das minhocas (Lavelle, 1997).

Segundo Lavelle (1993) apud Lavelle (1997), a maior limitação para a produção de biomassa de minhocas é a habilidade dos sistemas agrícolas em prover matéria orgânica fresca para alimentá-las, o que deve estar ocorrendo com a prática da poda periódica na área A12 (SAF). Também tem sido reportado um aumento na produção de reguladores de crescimento de planta nos coprólitos das minhocas (Krishnamoorthy e Vajranabhaiah, 1983; Tomati et al., 1988 apud Brown, 1995), embora os possíveis efeitos da minhoca mediando o aumento da produção de fito-hormônios nas plantas sob condições de campo não estejam bem claros.

$\mathrm{Na}$ área de SAF (A12), a qualidade do material disponibilizado para a alimentação da macrofauna, tanto proveniente de queda natural de folhas e galhos, quanto do material de poda (material fresco, com baixas relações $\mathrm{C}$ /nutrientes, apresentando muitos nutrientes solúveis), aliada ao microclima, devem estar favorecendo o desenvolvimento de saprófagos, como as minhocuçus, conforme observado em campo. A macrofauna condicionando uma maior disponibilidade de nutrientes no solo, acaba por favorecer o desenvolvimento de espécies vegetais mais exigentes, que contribuirão com material vegetal de melhor qualidade para a própria macrofauna, que também avançaria sucessionalmente num processo paralelo ao da vegetação, o que nos leva a considerar que há uma sucessão conjunta de todo o sistema.

Estudos de longo prazo têm confïrmado que as condições micro-ambientais que ocorrem nos excrementos podem também influenciar a sucessão de comunidades microbianas durante o envelhecimento dos excrementos (Martin \& Marinissen, 1993).

"Há fortes interdependências entre as raízes e a vida do solo, pois elas secretam substâncias que estimulam a biota do solo que, por sua vez, torna disponíveis os nutrientes que serão absorvidos pelas plantas" (Subba Rao, 1977; Lal, 1987 apud Reyintyes, 1994). A poda, interferindo sobre o metabolismo das plantas, pode atuar diretamente nas populações microbianas associadas ou próximas às raízes. Assim, a matéria orgânica, além de sua importância como reservatório de nutrientes e seu papel na ciclagem, que são abordados com maior ênfase nos estudos científicos, cumpre um 
papel fundamental como fornecedora de energia para toda a atividade da fauna e microflora do solo (Lavelle, 1997), que, com sua atividade, transformam o ecossistema solo, fazendo emergir nova qualidade no sistema solo-planta.

Potencializar os mecanismos responsáveis pela dinamização natural do sistema é uma forma promissora para se alcançar sistemas de produção mais sustentáveis. Isso pode se dar por meio de práticas de manejo que resultem numa melhoria da qualidade e quantidade de matéria orgânica, com conseqüente intensificação da atividade da biota do solo (Lavelle et al, 1993 apud Brown, 1995), e que, por sua vez, potencializem a disponibilização de nutrientes e outras substâncias que contribuem para a melhoria da fertilidade do substrato e do desenvolvimento das plantas, resultando na fertilização natural do sistema.

\section{IV.4.3. SERAPILHEIRA}

Santana et al. (1990) avaliaram a quantidade de resíduos recém-caídos (pelo método da malha suspensa) e usaram quadrado de $0,5 \mathrm{~m}$ de lado para a amostragem do material acumulado no chão (serapilheira) a fim de estimar a quantidade de detritos orgânicos existentes sobre o solo e avaliação do que isso representa em termos de reservatório de nutrientes e conteúdos de nutrientes, em agroecossistemas de cacau. No trabalho de Santana et al. (1990) a serapilheira mostrou tendência similar ao material recém-caído, em termos de quantidade de material acumulado e teores de nutrientes, de modo que, para este estudo de caso, considerou-se que a metodologia utilizada de coleta foi adequada e suficiente para se comentar a respeito do papel da serapilheira na ciclagem dos nutrientes e relacioná-lo com os dados de solo e macrofauna edáfica nas áreas estudadas (A12 - SAF e A0 - Capoeira).

Os dados obtidos por meio da amostragem da serapilheira utilizando-se os quadrados de $0,5 \mathrm{~m}$ de lado referem-se à quantidade estocada no momento. Os resultados referentes ao folhedo acumulado estão apresentados no ANEXO P e ilustrados na Figura IV.5. 


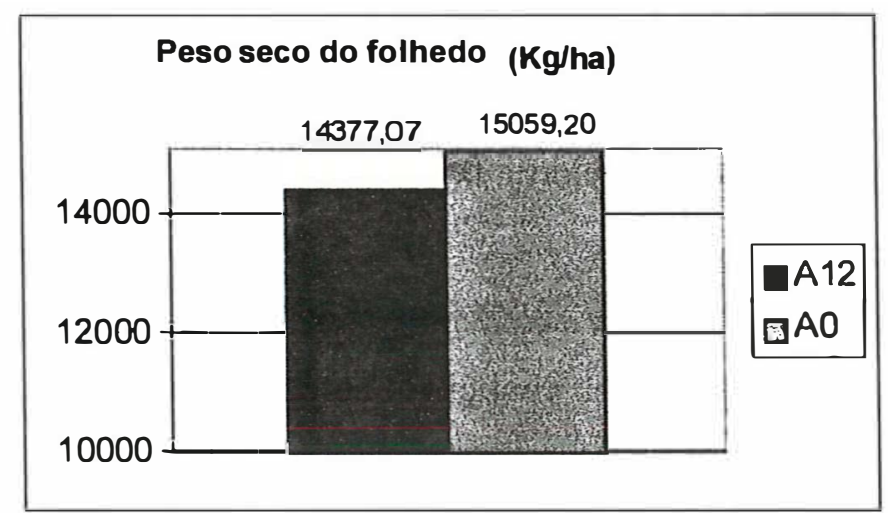

Figura IV.5 - Peso seco do folhedo para as duas áreas, (A12 - SAF e A0 - Capoeira), município de Ituberá, Bahia, Brasil.

A diferença do peso seco do folhedo não foi estatisticamente diferente (Tabela IV.4) para as duas áreas ( $\mathrm{A} 0$ e A12), o que não quer dizer que a qualidade e a dinâmica de decomposição são também semelhantes (Beare et al., 1995). Os valores da análise química do folhedo estão apresentados na Tabela IV.4 e os do material lenhoso no ANEXO Q, seguido dos valores do peso seco dessa fração da serapilheira no ANEXO R. Também pode-se encontrar os valores dos teores dos nutrientes nas folhas da serapilheira, em $\mathrm{Kg} / \mathrm{ha}$, no $\mathrm{ANEXO} \mathrm{S}$, e as relações das porcentagem dos teores dos nutrientes do folhedo, no ANEXO T, para as duas áreas comparadas. 
TABELA IV.4 - Quantidade média de material acumulado e respectivos conteúdos de elementos (\%), nas folhas da serapilheira coletada, seguido da análise estatística (teste t Student), para as duas áreas estudadas (A0 - capoeira e A12 - SAF), município de Ituberá, Bahia, Brasil.

\begin{tabular}{|c|c|c|c|c|c|}
\hline & \multicolumn{2}{|c|}{$\mathrm{A} 0$} & \multirow[t]{2}{*}{ Significância } & \multicolumn{2}{|c|}{ Al2 } \\
\hline & média & $\mathrm{CV}$ & & média & $\mathrm{CV}$ \\
\hline Peso seco & 1,13 & 34,63 & ns & 1,08 & 24,62 \\
\hline $\mathrm{pH}-\mathrm{CaCl} 2$ & 5,384 & 6,222 & $* *$ & 5,940 & 7,109 \\
\hline $\mathrm{N} \%$ & 1,269 & 13,856 & ** & 1,636 & 12,769 \\
\hline P2O5 \% & 0,012 & 34,021 & ** & 0,093 & 48,946 \\
\hline $\mathrm{K} 2 \mathrm{O} \%$ & 0,073 & 22,262 & $* *$ & 0,16 & 29,646 \\
\hline $\mathrm{Ca} \%$ & 1,676 & 28,309 & ns & 1,721 & 13,05 \\
\hline $\mathrm{Mg} \%$ & 0,136 & 13,859 & ** & 0,426 & 19,671 \\
\hline S \% & 0,092 & 63,788 & ns & 0,069 & 46,811 \\
\hline $\mathrm{C} / \mathrm{N}$ & 31,4 & 24,686 & ** & 21,12 & 21,712 \\
\hline
\end{tabular}

A análise química tanto da fração folhas como da fração lenhosa da serapilheira mostrou diferença estatística significativa entre as áreas para quase todos os nutrientes, exceto $\mathrm{Ca}$ e $\mathrm{S}$, mostrando claramente que há um estoque maior de nutrientes na serapilheira da área manejada do que na área de capoeira. Também com respeito ao $\mathrm{pH} \mathrm{e}$ a relação $\mathrm{C} / \mathrm{N}$, os dados confirmam uma maior eficiência na ciclagem dos nutrientes da área manejada (A12 - SAF), com o pH mais elevado e a relação $\mathrm{C} / \mathrm{N}$ mais baixa . A Figura IV.6 ilustra algumas dessas diferenças. 

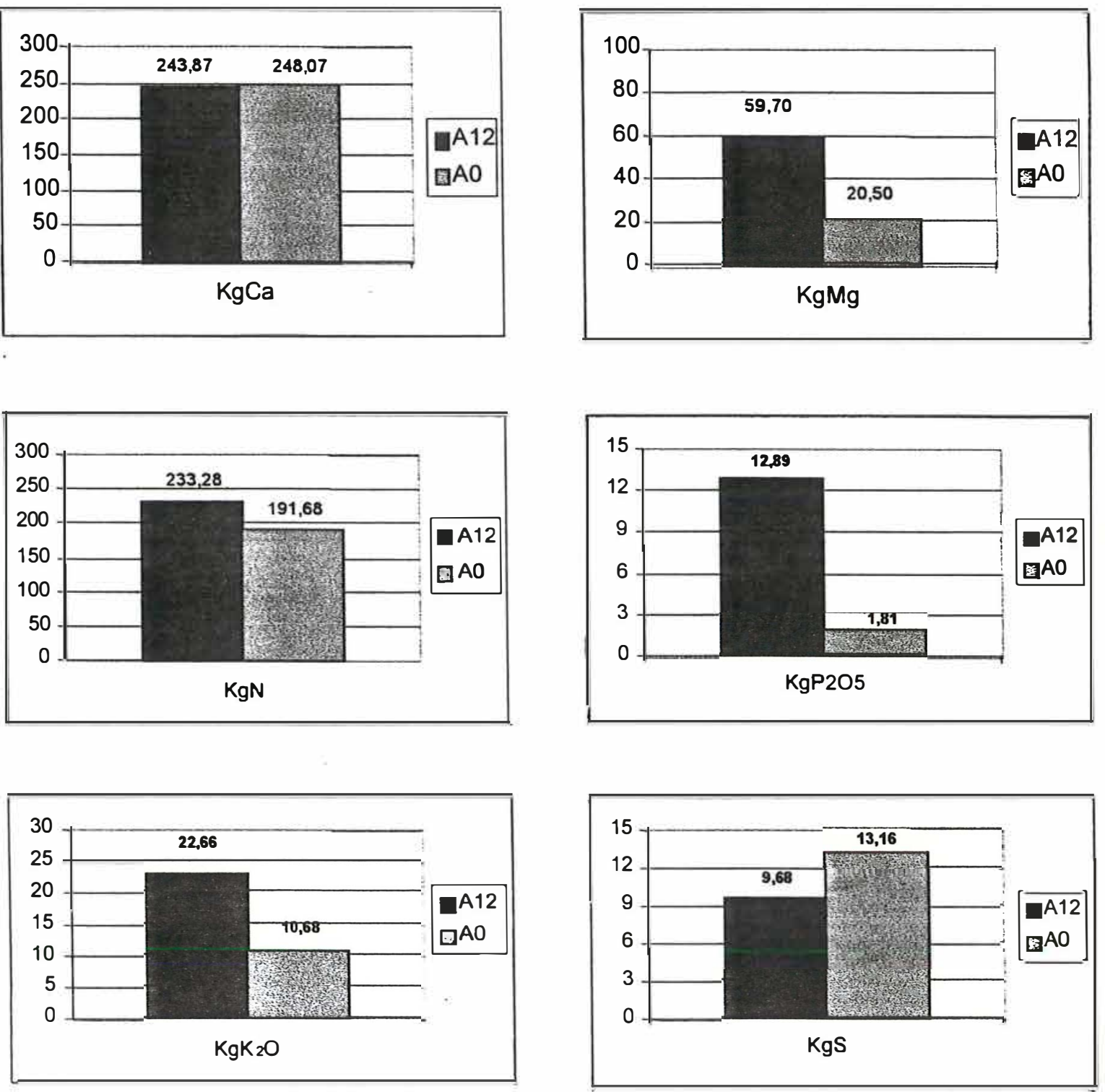

Figura IV.6 - teores de nutrientes (Kg/ha) armazenados no folhedo das duas áreas estudadas (A0 - capoeira e A12 - SAF), município de Ituberá, Bahia, Brasil.

Esses resultados reafirmam que a ciclagem dos nutrientes é acelerada na área de SAF (A12), propiciando maior disponibilização de nutrientes para as plantas. Esses resultados parecem estar diretamente condicionados pela prática da poda nesse sistema, manejo esse que acelera o processo de recuperação da fertilidade do solo. 
O compartimento vegetação define as características do compartimento serapilheira, que por sua vez interfere no compartimento solo, sendo os dois determinantes e determinados pelo compartimento fauna edáfica.

O manejo adotado nesse sistema, considerando todas as práticas de condução, possibilitou uma melhoria das relações entre os vários compartimentos, principalmente qualitativa, resultando numa eficiente recuperação da fertilidade do solo, com custo muito reduzido.

\section{IV.5. CONCLUSÕES}

Joung (1989) listou 10 hipóteses para pesquisas relativas à solo/agrofloresta: i) sistemas agroflorestais (SAFs) podem controlar erosão e reduzir perdas de matéria orgânica do solo e nutrientes; ii) SAFs podem manter a matéria orgânica do solo a níveis satisfatórios para a fertilidade do solo; iii) SAFs mantém mais favoráveis as propriedades físicas do solo do que a agricultura, através de uma combinação da manutenção da matéria orgânica e os efeitos das raízes das árvores; iv) árvores e arbustos fixadores de nitrogênio podem aumentar substancialmente os "inputs" de nitrogênio nos SAFs; v) o componente arbóreo pode elevar os "inputs" de nutrientes, tanto da atmosfera quanto dos horizontes $\mathrm{B}$ e $\mathrm{C}$ do solo; vi) SAFs podem levar a ciclagem de nutrientes mais fechada e portanto a um uso mais eficiente dos nutrientes; vii) a ciclagem das bases na serapilheira pode ajudar a reduzir a acidez do solo ou interromper a acidificação; viii) SAFs oferecem oportunidades de aumentar a • disponibilidade de água para as culturas; ix) SAFs podem ser um componente útil de sistemas para recuperar solos degradados; $\mathrm{x}$ ) na manutenção da fertilidade do solo sob SAFs, o papel das raízes das árvores é tão importante quanto a biomassa acima do solo.

O estudo do SAF conduzido pela sucessão natural com elevada diversidade permitiu responder pelo menos quatro dessas hipóteses colocadas por YOUNG (1989) sobre o efeito dos sistemas agroflorestais nos solos:

1. O manejo do componente arbóreo em sistemas agroflorestais aumentou os teores de nutrientes disponíveis do solo; 
2. O manejo adotado nesse SAF contribuiu para uma ciclagem e uso mais eficientes dos nutrientes;

3. O SAF testado mostrou-se muito eficiente para a recuperação de solos degradados;

4. O solo e seus componentes (raízes, fauna) tem papel importante na recuperação e manutenção da fertilidade dos solos em sistemas agroflorestais.

5. A prática da poda do componente vegetal nesse SAF, favorecendo o bombeamento de nutrientes e disponibilizando matéria orgânica fresca, foi responsável pela elevação dos níveis de nutrientes na serapilheira e nas camadas superficiais do solo e, principalmente fósforo, pela ativação da atividade da biota edáfica;

6. A adição de cálcio e magnésio pela calagem, que permanecem no sistema pela ciclagem biogeoquímica intensa proporcionada pela prática de manejo, pode ter contribuído decisivamente para o aumento da fertilidade do solo, com aumento do pH, disponibilização de $\mathrm{P}$ e aumento do V\%. 


\section{BIBLIOGRAFIA}

ALVIM, P.deT.; KOZLOWSKI, T.T. Ecophysiolgy of Tropical Crops. London: Academic Press. Inc. , 1977. 502p.

BEARE, M.H.; COLEMAN, D.C.; CROSSLEY JR, D.A.; HENDRIX, P.F.; ODUM, E.P. A hierarchical approach to evaluating the significance of soil biodiversity to biogeochemical cycling. Plant and Soil, v. 170, p. 5-22, 1995.

BENITES, J.R. Agroforestry systems with potencial for acid soils of the humid tropics of Latin America and the Caribbean. Forest Ecology and Management, v. 36, n. 1, p. 1-101, Aug. 1990.

BROWN, G.G. How do earthworms affect microfloral and faunal communitity diversity? In: The significance and regulation of soil biodiversity. Netherlands: H.P Collins, G. P. Robertson \& M.J. Klug (eds), Kluwer Academic Publishers. 1995 , p. $247-269$.

COPES, D.L. Effects of long-term pruning, meristem origin, and branch order on the rooting of Douglas-fir stem cuttings. Canadian Journal Forest Resource, v. 22, p. 1888-1894, 1992.

CURRY, J.P.; GOOD, J.A. Soil Degradation and Restoration. In: LAL, R. \& STEWART, B.A. Soil Restoration. New York: Ed. Springer-Verlag, 1992. (Advances in Soil Science Col., vol 17). Cap. 7, p. 171-203.

FIBGE. Mapa de Vegetação do Brasil. Rio de Janeiro: Fundação de Instituto Brasileiro de Geografia e Estatística, Ministério da Agricultura, 1992. 92 p. 
GABRIEL, J.L.C. Florísitica, fitossociologia de espécies lenhosas e aspectos da ciclagem de nutrientes em Floresta Mesófila Semidecídua nos municípios de Anhembi e Bofete, SP. Rio Claro, 1997. 193p. Tese de Doutorado - UNESP.

GARRITY, D.P. ; LEFROY, R.D.B. (ed.); BLAIR, G.J. (ed.); CRASWELL, E.T. The fate of Organic Matter and Nutrients in Agroforestry Systems. In: Soil organic matter management for sustainabel agriculture: a worshop held in Ubon, Thailand, aug. 1994. Proceedings n. 56. Anais, Camberra: ACIAR, 1995. p. 69-77.

GLOVER, N.; BEER, J.. Nutrient cycling in two traditional central american agroforestry systems. Agroforestry Systems, v. 4, n. 2, p. 77-87, 1986.

GOLLEY, F.B.; McGINNIS, J.T.; CLEMENTS, R.G.; CHILD, G.I.; DUEVER, M.J. Ciclagem de minerais em ecossistema de floresta tropical úmida. São Paulo: EPU/EDUSP, 1978. 256p.

GÖTSCH, E. Break-thropugh in agriculture. Rio de Janeiro: AS-PTA, 1995. 22p.

HAAG, P.H. (coord.) Ciclagem de nutrientes em florestas tropicais. Campinas: Fundação Cargill, 1985. 144p.

HAMILTON, W. E. \& SILLMAN, D.Y. Influence of earthworm middeens on the distribution of soil microarthropods. Biology and Fertilility of Soils, v. 8, p. 279284, 1989.

HENDRIX, P.F., CROSSley JR., D. A., BlAir, J. M. E COlEMAN, D. C. Components of sustainable agroecosystems. P. 637-654. In: EDWARDS, C. A.; LAL, R.; MADDEN, P.; MILLER, R.H.; HOUSE, G. Sustainable Agricultural Systems. Florida: Soil and Water Conservation Society - St. Lucie Press, 1990. p. 696-654. 
JORDAN, C.F. Nutrient Cucling Processes and Tropical Forest Management, cap.7. 159-180. In: GÓMEZ-POMPA, A.; WHITMORE, T.C. and HADLEY, M. Rain Forest Regeneration and Management. Paris: UNESCO, 1990. (Man and TheBiosphere Series, vol.6). Cap. 7, p. 159-180.

KANG, B.T.; AKINNIFESI, F.K.; PLEYSIER, J.L. Effect of agroforestry wood species on earthworm activity and physicochemical properties of worms casts. Biology and Fertility of Soils, v. 18, p. 193-199, 1994.

LAVELLE, P. Diversity of Soil Fauna and Ecosystem Function. Biology International, n.33, p. 3-16, Jul. 1996.

LAVELLE, P. Faunal activities and soil processes: Adaptative strategies that determine ecosystem function. Advances in Ecological Research, v. 27, p. 94-132, 1997.

LIMA, R. M. B. de. Descrição, composição e manejo dos Cultivos Mistos de Quintal na Várzea da "Costa do Caldeirão". 1994. Tese de Mestrado, INPA - Manaus.

LOPES, E.S.; DIAS, R.; FREITAS, S. DOS S. Influência dos Microorganismos na Nutrição dos cultivos nos trópicos. In: Reciclagem de Nutrientes e Agricultura de Baixos insumos nos Trópicos. Simpósio XVI Reunião de Fertilidade do solo. Ilhéus, 1985. Anais. Ilhéus: Caballa Rosand (ed) 1985. p. 77 - 101.

MARTIN, A.; MARINISSEN, J.C.Y. Biological and physico-chemical processes in excrements of soil animal. Geoderma, v. 56, p. 331-347, 1993.

PANIAGUA, A.; DASS, D.L.; MAZZARINO, M.J.; SOTO, M.L.; SZOTT, L.; DÍAZROMEU, R.; FERNÁNDEZ, C.; JIMÉNEZ, M. Cambios en facciones orgânicas e inorgânicas de fosforo en suelos com el uso de sistemas agroforestales. Agroforesteria en las Americas, v. 1, n. 2, p. 14 -19. Abr/jun. 1994. 
PRIMAVESI, A. O Manejo Ecológico do Solo: agricultura em regiões tropicais. São Paulo: Nobel, 1980. 541 p.

REIYNTYES, C. ; HAVERKORT, B. ; WATERS-BAYER, A. Agricultura para o futuro - uma introdução à agricultura sustentável e de baixo uso de insumos externos. Rio de Janeiro: AS-PTA, 1994. p. 324.

SANCHEZ, P.A. Sciece in agroforestry. Agroforestry Systems, v. 30, p. 5-55, 1995.

SANTANA, M.B.M.; CABALA-ROSAND, P.; SERÓDIO, M.H. Reciclagem de nutrientes em agroecossistemas de cacau. Agrotrópica, v. 2, n. 2, p. 68-74, 1990.

SHANG, C.; STEWART, J.W.B.; HUANG, P.M. pH effect on kinetics of adsorption of organic and inorganic phosphates by short-range ordered aluminum and iron precipitates. Geoderma, v. 53, p. 1-14, 1992.

SZOTT, L.T.; FERNANDES, E.C.M.; SANCHEZ, P.A. Soil -plant interations in agroforestry systems. Forest Ecology and Management, v. 45, n. 1-4, p. 127-152. Nov. 1991.

YOUNG, A. Tropical Soils and Soil Survey. London: Cambridge University Press, 1976. $468 \mathrm{p}$.

YOUNG, A. 10 Hypotheses for soil-agroforestry research. Agroforestry Today, v.1, n. 1, p. $13-16,1989$. 


\section{A PROPOSTA DE ERNST GÖTSCH PARA SISTEMA AGROFLORESTAL DIRIGIDO PELA SUCESSÃO NATURAL: ASPECTOS FILOSÓFICOS, CONCEITUAIS E PRÁTICAS DE MANEJO}

Nesse capítulo serão apresentados os aspectos filosóficos e os conceitos envolvidos na fundamentação teórica do sistema agroflorestal dirigido pela sucessão natural proposto por Ernst Götsch, além de uma descrição detalhada das práticas de manejo inerentes dessa proposta.

A apresentação do arcabouço filosófico-teórico-conceitual dessa proposta de SAF dirigido pela sucessão natural está fundamentada no conteúdo das entrevistas com seu idealizador (Ernst Götsch) e no conhecimento científico já disponível na bibliografia pertinente. $\mathrm{O}$ anexo 16 apresenta o manuscrito, elaborado pelo próprio autor para registro de suas idéias.

\section{V.I. O fundamento filosófico}

"Vista da distância da lua, o que há de mais impressionante com a Terra, o que nos deixa sem ar, é o fato dela estar viva" (Lewis Thomas - The Lives of a Cell apud Lovelock, 1991).

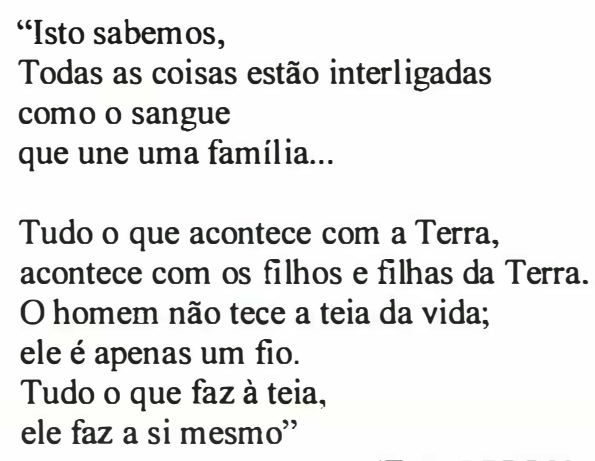

(TED PERRY, inspirado no Chefe Seattle, appud.Sahtouris, 1991). 


\begin{abstract}
"O pó estelar é do que somos realmente feitos, nós e tudo mais que existe no mundo que conhecemos" (Sahtouris, 1991).

"A Terra parece ser uma criatura "mara vilhosamente especializada em lidar com o sol" (Lewis Thomas apud Sahtouris, 1991).
\end{abstract}

O fundamento filosófico embasador desse sistema agroflorestal dirigido pela sucessão natural tem muito em comum com a filosofia que sustenta a teoria de Gaia (Lovelock, 1991). James Lovelock e Lynn Margulis apresentaram ao mundo científico a teoria intitulada "Teoria de Gaia", onde o processo de auto-regulação do Planeta Terra é a idéia-chave, mostrando "que há um estreito entrosamento entre as partes vivas do planeta - plantas, microorganismos e animais - e suas partes não vivas - rochas, oceanos e a atmosfera. Enunciada de maneira simples, a hipótese de Gaia afirma que a superfície da Terra, que sempre temos considerado o meio ambiente da vida, é na verdade parte da vida" (Capra, 1996).

Sahtouris (1991), ao comentar sobre a Teoria de Gaia, ressalta que a mesma “obriga que se tenha uma visão planetária. Esta teoria entende a evolução do ambiente físico e dos organismos como um todo fortemente unido, em um processo ou campo de ação único e indivisível. Gaia, como sua capacidade de homeostase, é uma propriedade emergente desse campo de ação" . "Uma mudança em uma espécie se refletirá por mudanças em outras. A evolução de ecossistemas inteiros ocorre à medida que criaturas vivas desenvolvem a si mesmas e reciprocamente, à medida que incorporam matériasprimas aos seus corpos e são transformadas em matérias-primas para outros corpos". O processo acima abordado (Sahtouris, 1991) nada mais é do que uma definição não conservadora de sucessão natural, que é o processo chave da fundamentação teórica do SAF proposto por Ernst Götsch. Nesse processo, que se desenrola no tempo, se pressupõe transformações sucessivas, tanto das formas de vida presentes no local, como das condições do próprio ambiente, condicionadas pelos organismos que nele vivem. $\mathrm{O}$ processo sucessional é inerentemente dinâmico. Um consórcio sempre dará lugar a outro, com composição distinta de espécies, se aquele já cumpriu sua função de preparar o nicho para espécies um pouco mais exigentes, melhorando e otimizando as condições ambientais. 
Na concepção de Götsch (1995), baseada em suas observações e teorizações, quando tentamos entender o ambiente, considerando também a organização e interação de suas formas de vida, devemos procurar inserir a atividade humana no fluxo de vida do Planeta, de forma a perseguir sempre um aumento de qualidade e quantidade de vida consolidada, aliando as necessidades humanas com a sustentabilidade dos recursos. Isso pressupõe preservar qualquer tipo de vida no ambiente e manter ou melhorar a qualidade ambiental, gerando recursos para possibilitar mais vida.

Se analisarmos os processos envolvidos no desenvolvimento de ecossistemas naturais no tempo, observaremos que a sucessão natural é sinônimo de aumento de recursos (sintropia $\left.{ }^{9}\right)$. Os ecossistemas naturais estão sempre mudando, de acordo com o processo sucessional, caminhando sempre para o aumento da qualidade e quantidade de vida consolidada (Götsch, 1995). Estas mudanças se dão numa dupla via: os seres vivos alterando o ambiente e o ambiente atuando sobre os seres vivos. Cada indivíduo é determinado pelo antecessor e determina o seu sucessor, e estes definem e são definidos pelo ambiente.

Podemos dizer que a filosofia que dá lastro aos conceitos fundamentais desse modelo de sistema agroflorestal se baseia na Teoria de Gaia e, na verdade, chega até a transcendê-la. Numa abordagem sistêmica, a agricultura, tida como uma prática modificadora dos ecossistemas e voltada para a produção, está inserida num contexto maior e faz parte da dinâmica da vida no planeta, tendo relação inclusive, com o cosmos. Ao elaborar sua teoria para compreensão da vida, que possibilita orientar a definição de ações sustentáveis em relação ao uso dos recursos naturais, Götsch chega a transcender a Teoria de Gaia, como paradigma recorrente, uma vez que ele, além de considerar o Planeta Terra um organismo vivo, onde todas as atividades dos organismos e fenômenos interagem, enxerga o Planeta dentro do contexto cósmico, sendo a vida uma das estratégias de existência do Planeta Terra. Segundo ele, a vida ocorre para que a existência seja possível; a vida é um dos instrumentários do Planeta para assegurar o equilibrio energético a fim de possibilitar a existência (ANEXO U).

\footnotetext{
${ }^{9}$ termo cunhado por E. Götsch para o conceito inverso de entropia
} 
De acordo com Ernst Götsch (ANEXO U), tudo no cosmos é inspiração e expiração. No caso, o sol estaria expirando e a terra inspirando, ou seja, captando a energia cósmica (lumínica, cinética de partículas, radioativa, etc.) e transformando-a em reserva de matéria complexa, que seria o armazenamento dos sub-produtos da vida e do metabolismo, através de cadeias orgânicas complexas como petróleo, turfa, carvão, etc., e inclusive, a própria atmosfera, que é fruto da atividade da vida no planeta, indo de encontro à definição de que os sistemas vivos tem limites e são abertos, no sentido de que eles capturam e excretam energia e matéria (Lovelock, 1991).

O Planeta comporta-se como um organismo, cujo metabolismo regula todos os sistemas do Globo. A luz é o único limitante do sistema (ANEXO U). Água e nutrientes, com manejo adequado, são disponibilizados pelo Planeta. Inclusive, é previsto que, de tempos em tempos ocorra renovação das fontes minerais para a vida, através da movimentação da crosta (placas tectônicas, que são digeridas pelo núcleo, o qual expele o magma e cinzas vulcânicas, renovando os nutrientes) ou mesmo reciclando esses nutrientes através do vento, das cinzas e das poeiras dos desertos (ANEXO U).

No que se refere à sustentabilidade das atividades humanas, Ernst Götsch é incisivo em afirmar que para que a espécie humana não seja "expulsa" (na verdade seria uma auto-expulsão) do Planeta, ela deve contribuir para o processo sintrópico de Gaia, participando ativamente na potencialização e catálise de tais processos.

O fundamento teórico desenvolvido por Ernst Götsch parte do princípio de que não há casualidade. Tudo na natureza funciona objetivando o equilíbrio energético do cosmos, de forma sintrópica. Para Götsch (ANEXO U), a base filosófica é teleológica pois pressupõe-se que os animais, o vento e tudo na natureza exercem sua função enquanto fatores que contribuem no sentido de gerar complexificação e não aumentar a entropia do Planeta.

Segundo Capra (1996), "os sistemas vivos são sistemas abertos que operam åastados do equilíbrio. A termodinâmica clássica, que lida com sistemas fechados no equilíbrio ou próximo dele, não é apropriada para descrever sistemas abertos em estados estacionários afastados do equilíbrio". 
A teoria de Götsch (ANEXO U) fundamenta-se na afirmação de que a vida dirige-se em sentido contrário ao da entropia, ou seja, ela é responsável por mais ordem, com mais complexificação e grande quantidade de informação armazenada. Para explicar este conceito inverso de entropia, Götsch cunhou o termo sintropia, de origem grega, que se assemelha no sentido ao termo "negentropia" de Schorödinger, (Lovelock, 1991), que também significa a recíproca de entropia. "Schorödinger concluía que, metaforicamente, a propriedade mais surpreendente e mais característica da vida é a sua capacidade de nadar contra a corrente, contra o fluxo do tempo. A vida é a contradição paradoxal à Segunda Lei da Termodinâmica, "que significa que quanto menos provável for uma coisa, mais baixa a sua entropia. Sendo a vida a coisa mais improvável de todas, ela deve ser portanto associada à mais baixa entropia", pois “... a vida evolui para uma complexidade cada vez maior e é caracterizada pela onipresença da improbabilidade" (Lovelock, 1991).

A aparente desordem ou "caos aparente" dos sistemas naturais esconde intrincados elementos responsáveis pela ordem dos sistemas. As espécies não estão distribuídas por acaso no espaço e não se desenvolvem de qualquer maneira, sob quaisquer condições. A organização dos ecossistemas reflete a estratégia do Planeta que é a complexificação e os mecanismos geradores da ordem são as condições ambientais, os animais (polinizadores e dispersores) generalistas ou especialistas, e ainda os organismos responsáveis pela cibernética do sistema como os decompositores, as formigas cortadeiras, as "pragas" e "doenças", os cipós "estranguladores", as plantas "parasitas", etc.

Os fenômenos considerados como perturbadores (ventos fortes, tempestades, vulcanismo, inundações, etc.) são tidos como importantes e estratégicos dinamizadores dos sistemas (ANEXO U).

As ações de manejo do SAF estudado nesse trabalho baseiam-se nestas premissas. Assim, a poda é inspirada na ação dos ventos e inundações, a partir de observações de harmonia na arquitetura e estratificação das plantas, muitas vezes indicadas pelo trabalho das formigas ou das abelhas arapuá (cortadeiras de folhas). Todas as intervenções se dão no sentido de aumentar, intensificar a vida e as condições 
para a vida, agindo no sentido da complexificação e sintropia, otimizando processos de fotossíntese, catalisando a reciclagem e o fluxo de carbono, participando do metabolismo saudável do Planeta Terra. Nessa proposta de sintropia, a pergunta deverá sempre ser invertida para “o que posso fazer de bom, para aumentar os recursos?", ao invés de “o que dá para explorar destes recursos?”. A atitude deverá vislumbrar sempre a funcionalidade, de trabalhar em prol da vida.

Portanto, no novo Paradigma de Götsch, é prevista uma mudança da visão cartesiana e antropocêntrica para uma visão biófila, que pressupõe uma ação participativa do homem na direção da complexificação, da sintropia, do aumento da qualidade e da quantidade de vida consolidada no Planeta (Götsch, 1995).

\section{V.II. Conceitos fundamentais que alicerçam o Sistema}

\section{Agroflorestal dirigido pela Sucessão Natural}

\footnotetext{
"O fator crítico e determinante da saúde e das taxas de crescimento, bem como da produtividade do sistema não era a qualidade inicial do solo, mas sim a composição e a densidade dos indivíduos da comunidade de plantas" (Götsch, 1995).

"A dinâmica da sucessão natural de espécies é sempre usada, mesmo em estágios mais avançados, como uma força que direciona o sistema e assegura a saúde e o vigor das plantas" (Götsch, 1995).

"Cada passo é uma tentativa de entrar e ser conduzido pelo fluxo de vida chamado 'sucessão natural"' (Götsch, 1995).
}

Os conceitos fundamentais nos quais se baseiam os SAFs dirigidos pela sucessão natural devem possibilitar a elaboração de diversos sistemas de produção, adaptados a cada situação particular, para qualquer lugar do planeta, pois os mesmos devem sempre ser inspirados no ecossistema original do local. Götsch (1995) esclarece que "se quisermos seguir o processo natural da sucessão de espécies, ou intervir com sucesso nas florestas naturais, é preciso ter um íntimo conhecimento do biótopo no qual se deseja interferir. É preciso identificar os nichos para as plantas que se quer cultivar, assim como saber quais devem ser removidas e é importante também entendermos as 
interações entre as culturas e as espécies nativas com todos os outros elementos da comunidade".

Os fundamentos e conceitos envolvidos na elaboração e condução do SAF abordado neste estudo de caso (Götsch, 1995) são: i) replicar os processos que ocorrem naturalmente; ii) compreender o funcionamento do ecossistema original no local; iii) assim como uma forma de vida dá lugar a outra, criando condições ambientais satisfatórias, um consórcio também cria outro (baseia-se na sucessão natural); iv) inserir a espécie de interesse para o homem no sistema de produção dentro da lógica sucessional, tentando se basear na origem evolutiva daquela espécie (condições ambientais originais, consórcios que geralmente acompanham a espécie, suas necessidades ecofisiológicas, etc.).

O método utilizado na elaboração e condução do SAF em questão, em essência, é uma tentativa de replicar as estratégias usadas pela natureza para aumentar a vida e melhorar o solo. Da mesma forma que na natureza, onde as plantas ocorrem em consórcios (e não isoladas) e requerem outras plantas para um ótimo desenvolvimento, neste SAF as plantas cultivadas são introduzidas em consórcio, de forma a preencher todos os nichos, inclusive considerando nessa combinação as espécies nativas remanescentes ou reintroduzidas. Além de combinar as espécies no espaço, combinamse os consórcios no tempo, assim como ocorre na sucessão natural de espécies, onde os consórcios se sucedem uns após outros, num processo dinâmico (Götsch, 1995).

Podemos fazer referência a sistemas de produção mais ou menos impactantes, predatórios ou degradantes. Ao se buscar a sustentabilidade ambiental, é condição sine qua non seguir a lógica da própria natureza, compreendendo sua estratégia de vida, atuando no sentido de possibilitar cada vez mais vida, ou seja, inspirando-se na sucessão natural e nos agentes naturais dinamizadores do sistema (vento, insetos, etc).

Uma área degradada, por ação antrópica ou natural, automaticamente sofrerá regeneração natural, tendo sua cobertura vegetal restabelecida, num crescente em qualidade e quantidade de vida (Götsch, 1995; Martins, 1990). Mesmo um solo terá naturalmente sua fertilidade restabelecida se deixado em pousio. A prática de pousio foi e continuam a ser amplamente utilizada pelas populações tradicionais ao fazer 
agricultura itinerante. O próprio exemplo disso é o SAF estudado nesse trabalho, que através de estratégias de manejo, foi possível recuperar solos empobrecidos e restabelecer florestas nativas em área degradada (Capítulos III e IV).

Este processo de regeneração natural, que pressupõe mudança da composição de espécies no espaço e no tempo, no sentido de aumento de qualidade e quantidade de vida é definido como sucessão natural. Sucessão é definida como a "lei universal" na qual "todo lugar vazio evolui para novas comunidades exceto aqueles que apresentam condições muito extremas de água, temperatura, luz ou solo" (Clements, 1916 apud McIntosh, 1981). Uma das características universais de todo ecossistema é a mudança contínua a que está submetido (Gómez-Pompa \& Wiechers, 1976).

Segundo Egler (1954), o processo clássico de sucessão secundária envolveria a substituição de grupos de espécies ao longo do tempo, à medida que estas predecessoras fornecessem condições mais favoráveis ao desenvolvimento das espécies já presentes na área, com crescimento lento e estabelecimento de espécies mais tardias.

Diversas tendências estruturais são esperadas ao longo do processo sucessional, onde o aumento na diversidade ( $\left.\mathrm{H}^{\prime}\right)$ e da eqüabilidade (J) constituem-se como padrões esperados, à medida que a comunidade evolui para um nível estrutural mais complexo (Odum, 1969). Além do aumento da biodiversidade, são notáveis as transformações ambientais no decorrer da sucessão, como a transferência de nutrientes livres do solo para a comunidade biótica, ao longo do processo, com conseqüente redução da perda, melhoria da estrutura edáfica, pela produção de matéria orgânica e modificações do microclima (redução da amplitude térmica e de umidade e aumento da umidade relativa do ar e do solo) (Gómez-Pompa \& Vazquez-Yanes, 1985).

O restabelecimento de uma cobertura vegetal natural, passando pelos vários estágios sucessionais, devolve ao solo o potencial produtivo de outrora. Na natureza a recuperação de solos degradados pode levar muito tempo, sendo a sua abreviação um dos propósitos das pesquisas atuais (Götsch, 1995).

De acordo com Götsch (1995), os fatores críticos que determinam a velocidade de ocorrência da recuperação natural são: i) a composição da comunidade de plantas; ii) a ordem em que as espécies ocorrem; iii) o momento de aparecimento destas espécies 
para cada ciclo; iv) a natureza destas interações com microorganismos e animais silvestres; v) as condições climáticas.

Para a dinamização do processo natural da sucessão é necessário um íntimo conhecimento do biótopo no qual se deseja interferir. É necessário conhecer as demandas das plantas que se deseja cultivar naquele ambiente, o seu nicho, as suas interações, inclusive com as espécies nativas, possibilitando estabelecer consórcios funcionais e fornecendo os subsídios necessários para ocupar os espaços de algumas espécies nativas por espécies de interesse para o homem, dentro da lógica sucessional, e seguindo a dinâmica da sucessão. De maneira geral, o processo sucessional preconizado por E. Götsch está sucintamente ilustrado com a Figura V.1.

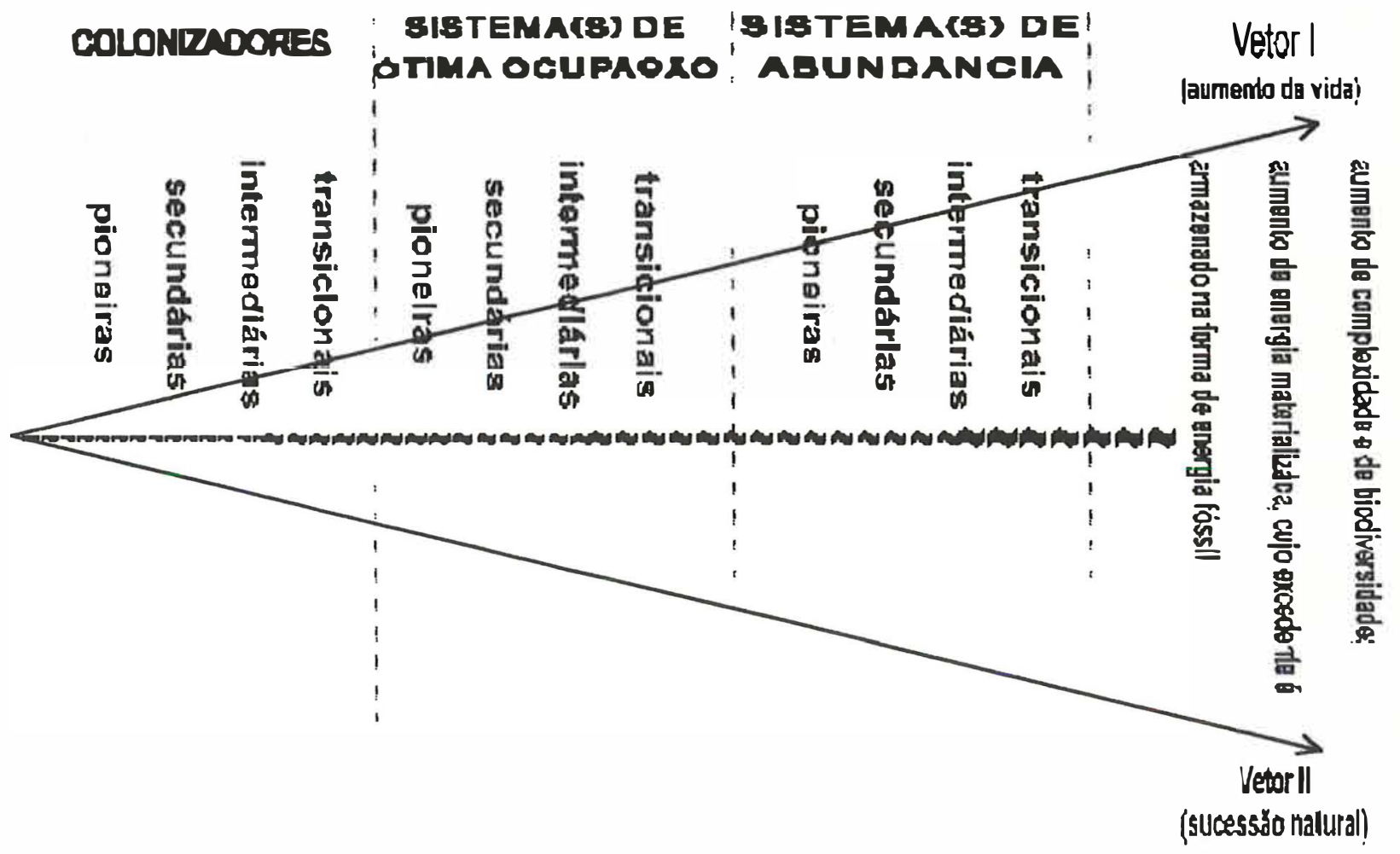

Figura V.1 - Figura ilustrativa do gráfico vetorial da vida, baseado na sucessão natural preconizada por E. Götsch (ANEXO U).

Sendo o conceito da sucessão natural preconizado por E. Götsch a idéia-chave que alicerça todo o sistema agroflorestal em questão, este será resumidamente apresentado a seguir: 
"Os seres vivos de cada lugar e em cada situação formam consórcios nos quais cada membro contribui com sua capacidade particular de melhorar e otimizar suas condições assim como aquelas dos membros do consórcio para crescerem, prosperarem e se reproduzirem. Cada consórcio dá origem a um novo consórcio, diferente na composição. Num dado lugar, os diferentes consórcios funcionam como um macroorganismo de alta complexidade passando por um processo de contínua transformação" (Götsch, 1995).

"Em cada local, cada consórcio dentro desse macroorganismo é determinado pelo precedente e determinará o que se seguirá. Na natureza o processo de transição entre os consórcios é lento e difuso. Esse processo contínuo é chamado de sucessão natural de espécies" (Götsch, 1995).

"Quando acontece, como é freqüente, o caso de duas plantas de diferentes consórcios de uma comunidade germinarem e crescerem simultaneamente, aquela do consórcio dominante irá direcionar o crescimento da outra, que somente virá a dominar quando o seu consórcio tornar-se o dominante. Apenas quando o consórcio dominante amadurecer e fenecer, o consórcio sucessor dominará, e assim começa um novo ciclo de crescimento e transformação" (Götsch, 1995).

Tendo esse entendimento da dinâmica do processo sucessional pode-se identificar alguns grupos de espécies, com características biológicas similares, conforme suas funções nos consórcios, como: Colonizadores (algumas bactérias e fungos, certos líquens, algas, musgos, samambaias, ciperáceas e ervas), que são os responsáveis pelo desencadeamento do processo sucessional (no caso de sucessão primária), a partir de condições muito inóspitas até tranformarem o ambiente, tornando-o capaz de sustentar formas de vida mais exigentes (que exijam aeração, boa umidade, disponibilidade de nutrientes, etc.).

Outra classe pode ser a das chamadas Pioneiras, que, para a denominação utilizada por Götsch (1995), são aquelas que recobrem o solo, com hábito decumbente ou prostrado, das várias formas de vida e não só as arbóreas (Budowski, 1965), que se desenvolvem bem a pleno sol, produzem grande quantidade de sementes, dispersas pelo 
vento, formam populações densas (muitos indivíduos); formando geralmente comunidade de baixa diversidade, com grande abundância dessas pioneiras.

As próximas a dominar a liderança do sistema são as espécies Secundárias, Intermediárias e Transicionais (do fim de um consórcio sucessional), e novamente o ciclo se inicia. Dependendo do tamanho da área aberta ou das condições ambientais atingidas, a sucessão pode recomeçar com outras espécies pois, o ambiente foi modificado. As espécies pertencentes a estas fases sucessionais apresentam ciclo de vida longo (em ordem crescente das fases do consórcio), frutos geralmente dispersos por aves e animais de grande porte (frutos carnosos), são mais exigentes em recursos e demandam sombra no início do seu desenvolvimento, formando banco de plântulas, quanto mais avançadas na sucessão dentro do consórcio.

O processo sucessional, para sua melhor compreensão pode ser dividido em sistemas sucessionais, caracterizados por diferentes consórcios com ocorrência concomitante de espécies tipicamente pioneiras, secundárias, intermediárias e transicionais, de acordo com as características do ecossistema estudado (Figura V.1). Os representantes de todas as fases crescem juntos, porém, em cada fase da sucessão haverá uma comunidade dominante, dirigindo a sucessão. Para cada consórcio, os indivíduos das espécies mais avançadas na sucessão não se desenvolvem enquanto os iniciais não dominam (ANEXOS $\mathrm{V}, \mathrm{W}$ e X). As plantas precisam ser tutoradas pelas antecessoras. Neste processo, podemos dizer, pela abordagem sistêmica, que a planta não morre, é transformada. A transformação é justamente o que dá idéia de continuidade, de dependência, entre todos os indivíduos no tempo, durante todo o processo sucessional (Götsch, 1995).

Nessa proposta, a valorização do conhecimento tradicional local é fundamental, pois entre outras coisas, pode contribuir para a identificação de plantas indicadoras de nichos.

É interessante comentar que as técnicas de cultivo utilizadas na agricultura convencional, inclusive nos SAFs convencionais (como uso de agrotóxicos para controle de plantas daninhas e controle de pragas e doenças; uso de fertilizantes solúveis ou orgânicos de fora da área cultivada) não são abordadas como técnicas de manejo dessa 
proposta de SAF dirigido pela sucessão, porque está alicerçado em outro paradigma. Inclusive, o próprio conceito de competição, muito presente nos sistemas agrícolas convencionais, tem um sentido muito distinto nessa proposta (Götsch, 1995).

A partir de inúmeras observações de que, na floresta existem árvores enormes de espécies diferentes, ocupando estratos diferentes, que convivem saudavelmente uma ao lado da outra, quase que no mesmo local, presume-se que para que não haja competição é preciso acertar na combinação das espécies, respeitando os estratos de cada planta, sua relação com as outras na sucessão, suas exigências ambientais (luz, nutrientes, etc.), o sinergismo entre as plantas (liberação de exudatos, hormônios), etc.

Da mesma forma como ocorre na floresta tropical, duas ou mais espécies podem dividir espaços muito próximos (por exemplo na mesma cova), desde que desempenhem diferentes funções e ocupem diferentes nichos e estratos no consórcio. Assim, fica alterado o conceito de competição entre plantas, pois só haverá competição se as plantas concorrerem pelos mesmos recursos, o que não deve ocorrer se o papel das mesmas forem complementares no ecossistema (Götsch, 1995).

A maioria das plantas de interesse para o uso do homem se encaixa nos consórcios dos sistemas de abundância (Figura V.1), pois geralmente são plantas mais exigentes. Se atentarmos para o fato de que paralelamente à sucessão vegetal ocorre uma sucessão animal (Curry \& Good, 1992), e se lembrarmos de que os animais de grande porte são mantidos por sistemas de abundância, já avançados na sucessão, então poderemos encaixar a espécie humana como dependente de sistemas ricos em recursos, com capacidade de suportar animais e plantas exigentes, ou seja, sistemas com grande qualidade e quantidade de vida consolidada. As matas ciliares são exemplos desse ambiente, onde há freqüente dinamização quer via "poda", pelo vento, ou renovação de recursos pelas enchentes periódicas.

Dessa forma, os animais podem ser vistos também como "ajudantes", distribuidores, intermediadores, dispersores, transformadores, que dinamizam o processo sucessional (Götsch, 1995). As formigas cortadeiras têm sido muito consideradas nesse papel, pois pelo fato de cortarem as plantas que estão criando tensão no consórcio (Götsch, 1995) podem ser usadas como indicadoras do que deve ser podado ou retirado 
do sistema. Segundo Götsch (1995), as formigas cortam as folhas das espécies cuja relação entre os estratos não está coerente e para que o sistema sucessional evolua é preciso introduzir e conduzir consórcios corretos, efetuando o manejo adequado.

$\mathrm{O}$ uso de insumos em sistemas de produção é tida como uma "muleta" para manter certo nível de produtividade que o ambiente por si só não é capaz de manter (Götsch, 1995). O uso dos insumos ocorre como estratégia para suprir uma falha na sucessão, pois o ambiente não está apto para acolher as plantas introduzidas para produção, mostrando que está numa situação de sucessão anterior ao sistema de abundância (Figura V.1), que é o sistema onde as plantas alimentícias mais produtivas devem se desenvolver, por serem mais exigentes. Assim, as plantas introduzidas em um sistema não propício para o seu desenvolvimento, apresentarão sintomas de deficiência de nutrientes, não se desenvolverão adequadamente e provavelmente sofrerão "danos" com o "ataque" de insetos e doenças. Uma das estratégias mais efetivas contra o ataque de insetos é assegurar o vigor e saúde da plantação (Chaboussou, 1987). Se a dinamização da ciclagem de nutrientes, a biodiversidade e a sucessão ecológica estiverem asseguradas no sistema, o "input" de insumos será dispensável, pois dirige-se o local para um patamar mais elevado na sucessão.

A otimização desses sistemas de produção (Götsch, 1995) dependem de alguns passos: i) primeiro, identifica-se as espécies adequadas, os consórcios de espécies e sucessão de consórcios que ocorrem na região, em solos ou climas similares; ii) para otimizar os processos de vida, tenta-se chegar à maior biodiversidade possível no sistema para preencher todos os nichos gerados; iii) identifica-se o momento mais apropriado para o início de cada ciclo, isto é, do plantio ou manejo de um consórcio mais avançado, de modo que cada espécie encontre as melhores condições para se estabelecer e crescer; iv) acelera-se a taxa de crescimento e evolução sucessional do sistema empregando o instrumentário da poda e da remoção de plantas.

Para tentar entender essa complexidade aparentemente caótica que é a floresta tropical, como um mosaico de diferentes idades e estágios sucessionais e a fim de tornar mais compreensível a adoção e práticas de manejo de SAFs, é interessante que se agrupem as espécies que naturalmente ocorrem em consórcios ou classes funcionais, de 
modo que seja possível identificar certos padrões. De acordo com Götsch (1995), é possível caracterizar as espécies segundo seus grupos sucessionais por meio de informações a respeito de: i) duração do ciclo de vida; ii) altura do estrato que naturalmente ocupa; iii) padrão de ocupação; iv) características arquiteturais e v) função sistêmica das espécies. Dessa forma, é necessário conhecer as necessidades de cada espécie quanto à quantidade e qualidade de vida consolidada, para que ela possa se estabelecer e chegar a dominar (Götsch, 1995).

\section{V.3. As práticas de manejo nos SAFs dirigidos pela sucessão natural na Mata Atlântica}

"O comportamento de sistemas caóticos não é meramente aleatório, mas exibe um nivel mais profundo de ordem padronizada. O comportamento caótico é determinista e padronizado, e os atratores estranhos nos permitem transformar os dados aparentemente aleatórios em formas visiveis distintas." (Capra, 1996).

No caso desse SAF dirigido pela sucessão natural, o manejo justamente se dá no sentido de aumentar a probabilidade da organização dos elementos do sistema para resultar a condição de avanço na sucessão. Naturalmente isso iria acontecer mas demoraria mais. É sistematizando as regras que organizam o caos aparente do ecossistema, como as regras envolvidas na dispersão, polinização, transformação e criação de nichos...) que o processo sucessional é acelerado.

De forma geral, os dois instrumentos ou técnicas de manejo que aceleram o processo sucessional utilizados neste $\mathrm{SAF}$ em questão são a capina seletiva e a poda.

Segue adiante, de forma sucinta, uma descrição das práticas utilizadas no manejo e implementação do SAF em questão:

\section{V.3.1. Capina Seletiva}

A capina seletiva consiste numa prática de manejo onde apenas as plantas pioneiras nativas ou plantadas (gramíneas, herbáceas e trepadeiras) são arrancadas ou cortadas quando senescentes ou maduras, poupando aquelas que ocupam uma posição mais avançada na sucessão. Nessa prática, as plantas jovens que espontaneamente 
tenham surgido no agroecossistema e que ainda não completaram sua função ou não terminaram seu ciclo de vida são mantidas e tutoradas.

Muitas plantas nativas oriundas da regeneração natural, quando manejadas apropriadamente, são consideradas excelentes companheiras das espécies cultivadas na área. Quando jovens, essas plantas podem estimular o crescimento das plantas cultivadas e afastarem pragas e doenças (Götsch, 1995). Elas também protegem e melhoram o solo, bem como contribuem consideravelmente para o fornecimento de matéria orgânica ao sistema, consistindo numa fonte valiosa de nutrientes e fonte de energia para a biota do solo, que dinamizará a ciclagem de nutrientes e a conseqüente recuperação do solo (GÖTSCH, 1995).

\section{V.3.2. Poda}

A prática da poda pode ser resumida da seguinte maneira: árvores e arbustos quando em estádio de maturidade são rejuvenescidos pela poda; árvores e arbustos que já cumpriram suas funções de melhorar o solo e foram substituídos por indivíduos do consórcio sucessor são cortados e toda sua biomassa é devidamente picada e bem distribuída sobre o solo, tomando-se o devido cuidado para que os tecidos lenhosos (galhos e troncos) fiquem em contato direto com o solo.

Além da condição de maturidade do indivíduo, outros fatores também são considerados para a prática da poda, como a sua adequação na estratificação da comunidade. Deve-se atentar para a planta existente abaixo daquela que será podada, que irá substituí-la no próximo consórcio. Dessa forma, leva-se em consideração tanto a planta que vai ser podada quanto a planta que sofrerá as conseqüências dessa poda, já que a poda interferirá na disponibilidade de luz, espaço e oferta de matéria orgânica no sistema (Götsch, 1995).

A poda interferindo na mudança de espaço na estratificação, disponibilidade de luz, de biomassa, acaba por atuar como um instrumento de manejo para corrigir tensões no sistema. A poda é então efetuada a partir de observações arquiteturais, pelo ataque de 
patógenos, de formigas cortadeiras, de insetos herbívoros ou brocadores, de abelhas arapuá, etc.

No manejo do SAF estudado, todos os esforços são dirigidos para reciclar e aumentar a quantidade de matéria orgânica produzida. Quando se efetua a poda ou remoção das plantas, o material morto é depositado sobre o solo como "mulch", que além de proteger o solo, enriquece-o com nutrientes, dinamiza a biota do solo, que reflete na melhoria da estrutura física, retenção de água e aspectos da química em geral (Götsch, 1995).

A poda permite a produção de biomassa ofertada, de matéria orgânica de boa qualidade, e essa biomassa pode ser acumulada no pé da planta mais exigente. Assim, pode-se trabalhar a partir de pontos favorecidos, dos quais pode se dar o crescimento de núcleos de vegetação no sentido do avanço sucessional (Götsch, 1995).

Quando a matéria orgânica é disponibilizada através da poda ocorre uma dinamização da vida do solo, deixando-o propício ao desenvolvimento vegetal, principalmente dos consórcios mais avançados, o que leva a dispensa do uso de fertilizantes (Götsch, 1995).

A poda permite um bombeamento dos nutrientes das camadas mais profundas do solo para a superficie, uma vez que a raiz pode extrair mais nutrientes da matriz do solo, ao explorar um volume maior do substrato pela renovação constante do sistema radicular; o fósforo fixado, por exemplo, passa a ser disponibilizado na decomposição da matéria orgânica. Na poda ocorre ainda liberação dos nutrientes de uma matéria orgânica de melhor qualidade, onde os nutrientes não foram translocados, como ocorre na abscisão foliar, promovendo a dinamização da biota do solo.

O rejuvenescimento da comunidade é um dos efeitos da poda mais salientados por Götsch (1995), que descreve o processo como: "As plantas que estão na fase de crescimento exuberante estimulam e ativam todos os membros da comunidade vegetal ao seu redor. Da mesma forma, as plantas do consórcio dominante que estão em estádio de maturidade ou senescência induzem, a todas as suas vizinhas, interrupção de crescimento e aparecimento de sinais de maturidade e senescência, atípicos para seus estágios de desenvolvimento." (Götsch, 1995). Sem dúvida há necessidade de mais 
pesquisas sobre os efeitos da poda tanto sobre o indivíduo podado como sobre a comunidade vegetal adjacente ao mesmo. Oldeman (1976) cita que "... Gradualmente a morfogênese negativa chega a dominar, o ponto de inversão morfológica ascende, e a copa torna-se rala. Este estado de equilibrio (steady state) chega ao fim com a senescência, quando árvores do presente são exauridas e aquelas do futuro, reprimidas, contidas, por um longo tempo".

Segundo Götsch (1995), a poda exerce diversos efeitos sobre as plantações, entre eles: i) rejuvenescimento da comunidade; ii) acelera, interfere e direciona o processo orgânico de sucessão; iii) prolonga o tempo da fase juvenil de espécies pioneiras de vida curta, aumentando o seu potencial de melhorar o solo. Os fatores do sistema influenciados pela poda são: i) luz; ii) espaço e iii) matéria orgânica, que exercem influência sobre inúmeros aspectos químicos, físicos e biológicos do solo.

\section{V.3.3. Consórcios / Alta densidade de plantio / Plantas estratégicas}

Com a prática do plantio de consórcios adensados tenta-se preencher os diversos nichos com as culturas de interesse econômico, usando alta densidade de plantio em policultura (com a mesma densidade usada em monocultura, só que combinadas entre pioneiras, secundárias, intermediárias e transicionais (Figura V.1, ANEXOS V, W e X). Em termos de espaçamento, é como se fossem várias monoculturas sobrepostas na mesma área, aproveitando melhor todos os fatores de produção, diminuindo assim, a participação das plantas espontâneas de ciclo curto, que senesceriam rapidamente.

Ao lidar com altas densidades de plantio aumenta-se a probabilidade de se encontrar um nicho satisfatório ao desenvolvimento da espécie e não difere da estratégia que já ocorre na própria natureza, onde nem todas as plântulas são recrutadas, provavelmente por não estarem em nichos adequados, e também trata-se de um mecanismo de escape à predação (Götsch, 1995). As plantas que não se desenvolverem vigorosamente poderão desempenhar o importante papel de produzir biomassa e rejuvenescer o sistema como resposta à poda. 
Desenhar e plantar um consórcio ótimo de plantas no qual todos os parâmetros sejam levados em consideração seria praticamente impossível. As espécies locais que vão surgindo espontaneamente ajudam êm indicar os nichos e como ocupá-los, de forma temporária ou permanente, podendo contribuir também para melhoria das condições ambientais através da poda quando estiverem sendo substituídas por espécies ecofisiologicamente similares de gerações futuras. As espécies de regeneração natural, referidas aqui de espontâneas, complementam as espécies cultivadas e ajudam o manejador do agroecossistema, funcionando como indicadores naturais das condições ambientais. O conhecimento tradicional pode contribuir muito para apontar as melhores plantas indicadoras, além de auxiliar com informações a respeito da exigência ambiental das espécies nativas, comportamento sucessional e outras características (Götsch, 1995).

Uma observação interessante que merece destaque é que onde os solos eram melhores no início da implantação do sistema, o cacau e a banana produziram muito bem mas quando as árvores do primeiro consórcio (corindiba - Trema micrantha - e embaúbas brancas - Cecropia spp. - que cresceram espontaneamente) saíram do sistema, por não terem sido introduzidas espécies "do futuro", o sistema ficou dessincronizado, e acabou regredindo, acarretando a morte dos cacaueiros e bananeiras. As espécies de futuro introduzidas estavam muito distantes uma das outras, pois considerou-se o diâmetro da copa depois de adultas. Portanto, faltaram os degraus na sucessão. É preciso estarem presentes as espécies de todas as fases sucessionais do consórcio presente, inclusive aquelas que fazem parte do consórcio seguinte e que devem ser criadas pelas transicionais do consórcio antecessor. Assim, as poucas árvores de cacau e bananeiras próximas a às árvores que não estavam senescentes continuavam produtivas e vigorosas (Götsch, 1995).

"Em contraste, nos lugares que inicialmente tinham solos pobres, as bananeiras não se estabeleceram, nem suas companheiras na vegetação natural, como a corindiba e embaúba-branca. Nestas áreas a vegetação pobre e os espaços abertos foram transformados por mim por plantar alta densidade de um grande número de espécies conhecidas por irem bem sob condições similares. Eu plantei pioneirais como capimelefante, mandioca, abacaxi, coarana, etc., para melhorar o solo, e árvores de floresta 
secundária como jangada, preta, ingá, etc., e árvores frutíferas, de castanha e para madeira, em grande densidade para alcançar uma próspera agrofloresta capaz de produzir bem a médio e longo prazos." (Götsch, 1995).

"Esta operação foi de grande sucesso, mas somente naquelas partes dos campos onde tínhamos podado fortemente ou cortado drasticamente os indivíduos de árvores pioneiras em estádio de amadurecimento da vegetação já estabelecida no momento da introdução das espécies complementares. Nestas parcelas, então, toda a comunidade de plantas começou a se desenvolver e agora representa a parte mais produtiva das plantações" (Götsch, 1995).

Com este sistema e manejo e implantação, apesar da consolidação ter sido lenta, conseguiu-se um sincronismo entre os consórcios, o que assegurou o processo sucessional sem obstáculos.

Concluiu-se com isso que o fator crítico que determina a saúde, taxa de crescimento e produtividade do sistema não era a qualidade inicial do solo, mas a composição e densidade de indivíduos da comunidade de plantas e a presença de plantas de geração futura. A ordem em que as culturas foram introduzidas também era muito importante, pois a maioria das espécies só cresceu vigorosamente quando entraram no fluxo da sucessão das espécies assim que elas pudessem vir a dominar (ex: a pioneira sempre deve sombrear, "criar" uma secundária, e não o contrário).

Götsch concluiu, depois de muita observação, que as parcelas de maior sucesso foram aquelas nas quais ele tinha se baseado da maneira mais correta no processo natural da sucessão das espécies.

A proximidade do referido SAF com remanescentes de floresta nativa, com baixa perturbação antrópica, facilitou o trabalho por incentivar a regeneração natural através do banco e chuva de sementes, mas isso não deve ser considerada uma condição sine qua non para que se efetue este tipo de SAF. Kageyama et al. (1994) nos chama a atenção para o monitoramento genético das populações das espécies a fim de que o sistema seja também geneticamente sustentável, para que, a partir de coleta de sementes de grandes populações, evite-se a endogamia e a erosão genética. 
A implantação do referido SAF e a decisão das intervenções estão fundamentados nos seguintes fatores (Götsch, 1995): i) plantio adensado (visando aproveitamento dos diferentes nichos; ii) biodiversidade (com espécies de interesse econômico e nativas, inclusive através do manejo da regeneração natural; iii) sincronia (considerando o momento de introdução dos consórcios); iv) estrato; v) ciclo de vida; vi) necessidades e funções ecofiosiológicas das espécies; vii) plantas estratégicas: a) substituição das espontâneas por outras mais eficientes em produção de biomassa; b) atrativas e repelentes de insetos; c) que organizam o sistema, por exemplo, algumas espécies que absorvem metais que poderiam ser tóxicos às plantas cultivadas se presentes em altas concentrações no solo.

Com relação à viabilidade da implantação e condução dos SAFs orientados pela sucessão natural, a demanda por mão-de-obra é concentrada no momento de implantação do SAF, portanto, a prática em mutirões é sempre indicada. O manejo é feito a partir de cinco intervenções ao ano, aproximadamente (para os dois primeiros anos), e depois, três intervenções ao ano já são suficientes. É interessante atentar para as condições de trabalho no SAF, que passam a ser mais agradáveis se comparados aos serviços braçais demandados pela agricultura convencional, e além disso não há o risco de intoxicação do trabalhador.

Pode-se observar, neste caso estudado, que as intervenções (da implantação ao manejo) no SAF sob a perspectiva agroecológica, dirigido pela sucessão natural, são precisas e delicadas, como numa condição de jardinagem, porém estes aspectos podem ser considerados não como obstáculos, mas como estimuladores e interessantes, primeiro porque resgatam o conhecimento tradicional e torna o agricultor protagonista de todo o processo, consciente de suas intervenções, e segundo porque, embora o grande rigor e cuidado em selecionar as espécies ao proceder a capina, em executar uma poda adequada e bem feita se constituam como trabalhos árduos no início, as intervenções serão menos necessárias conforme a área vai evoluindo sucessionalmente e tornando-se mais produtiva. Trata-se de uma forma diferente de se enxergar a agricultura e a função do homem frente a natureza. 
Tal demanda de conhecimento, ao contrário do que pode se pensar, transfere mais poder ou dignidade ao agricultor, pois seu conhecimento é valorizado e ele pode se sentir participante como ser sintrópico no Planeta (Götsch, 1995). Além disso, se houver uma pressão por parte dos consumidores, ao valorizarem as qualidades descritas acima, o agricultor poderá conseguir mais espaço no mercado, tendo uma comercialização mais promissora de seus produtos (Ehlers, 1996). 


\section{BIBLIOGRAFIA}

BUDOWSKI, G. Distribuition of tropical american rain forest species in the light of successional process. Turrialba, v. 15, p. 40-42, 1965.

CAPRA, F. A teia da vida - uma nova compreensão científica dos sistemas vivos. São Paulo: Cultrix, , 1996. 256p.

CURRY, J.P.; GOOD, J.A. Soil Degradation and Restoration. In: LAL, R. \& STEWART, B.A. Soil Restoration. New York: Ed. Springer-Verlag, 1992. (Advances in Soil Science Col., vol 17). Cap. 7, p. 171-203.

EGLER, F. E. Vegetation science concepts. Inicial floristic composition, a factor in oldfield vegetation development. Vegetatio, v. 4, p. 412-7, 1954.

EHLERS, E. Agricultura Sustentável. Origens e perspectivas de um novo paradigma. Livros da Terra, São Paulo, 1996. 178p.

GOMEZ-POMPA, A. \& VÁSQUEZ-YANES, C. Estudios sobre la regeneración de selvas en regiones calido-humedas de Mexico. In: GÓMEZ-POMPA, A.; DEL AMO, R. (eds.). Investigaciones sobre la Regeneratión de Selvas Altas en Vera Cruz, México. México: Compañia Editora Continental, 1985. Cap. 1, p. 1-27.

GOMEZ-POMPA, A. \& WIECHER, B.L. Regeneratión de los Ecossistemas Tropicales y Subtropicales. In: GOMÉZ-POMPA, A.; RODRÍGUEZ, S. del A.; VÁSQUEZYANES, C.; CERVERA, A.B. (eds). Invertigaciones sobre la Regeneracion de Selvas Altas en Vera Cruz, México. México: Compañia Editora Continental, 1976. p. 11-30.

GÖTSCH, E. Break-thropugh in agriculture. Rio de Janeiro: AS-PTA, 1995. 22p. 
KAGEYAMA, P.Y.; SANTARELLI, E.; GANDARA, F.B.; GONÇALVES, J.C.; SIMIONATO, J.L.; ANTIQUEIRA, L.R.; GERES, W.L. Revegetação de áreas degradadas: modelos de consorciação com alta diversidade. In: II Simpósio Nacional sobre Recuperação de Áreas Degradadas, Piracicaba, 1994. Anais, Piracicaba: IPEF, 1994. p. 569-576.

LOVELOCK, J. As Eras de Gaia. Ed. Campus, São Paulo, 1991, 236p.

McINTOSH, R.P. Forest Succession: concepts and application. In: WEST, D.C.; SHUGART, H.H.; BOTKIN, D.B. Succession and Ecological Theory. Nex York: Springer-Verlag, 1981. Cap. 3. P. 10-23.

ODUM, E.P. Ecologia. Rio de Janeiro: Ed. Guanabara, 1988. 434p.

OLDEMAN, R. A.A. Architeture and energy exchange of dicotyledonous trees in the forest. In: THMLINSON, P. B. \& ZIMMERMANN. Tropical trees as living systems. London: Cambridge University Press., 1976. p. 535-560.

SAHTOURIS, E. Gaia: do Caos ao Cosmos. São Paulo: Ed. Interação, 1991. 308p. 


\section{CONCLUSŌES}

O Sistema Agroflorestal dirigido pela sucessão natural apresentou-se como um sistema de produção comprovadamente capaz de recuperar áreas degradadas, aliando produção à conservação, recuperação, manutenção, ou ainda, melhoria da qualidade, dos recursos naturais. A implantação e condução do SAF mudou completamente a cobertura vegetal da área manejada, assim como a qualidade da serapilheira, fertilidade do solo e macrofauna edáfica, se comparada com a Capoeira (ou seja, se a intervenção não tivesse sido realizada).

O manejo utilizado no SAF possibilitou aceleração e avanço na sucessão natural da vegetação e da macrofauna edáfica, acompanhado por uma melhoria da qualidade dos recursos para a vida (fertilidade do solo e dinamização da ciclagem dos nutrientes).

Essa recuperação ou recondicionamento ambiental diz respeito tanto aos parâmetros vegetacionais quanto aos parâmetros edáficos, sobre o que pode-se concluir, mais especificamente, a partir desse estudo de caso:

1. A vegetação das duas áreas estudadas A0 - Capoeira e A12 - SAF mostraram-se diferentes florística e estruturalmente depois de 12 anos, ao se efetuar manejo em uma (Al2) e ter deixado em pousio a outra (A0);

2. Observou-se um avanço sucessional na A12 (SAF) se comparado com A0 (Capoeira), com marcante presença de indivíduos das famílias Mimosaceae, Lauraceae e Caesalpiniaceae (encabeçando em ordem decrescente, respectivamente, a lista quanto ao número de indivíduos), enquanto que na A0 (Capoeira) a família Melastomataceae foi, de maneira muito evidente, a que prevaleceu dentre as outras quanto ao número de indivíduos;

3. A A12 (SAF) apresentou maior diversidade, embora tenha apresentado menor número absoluto de espécies, se comparada com a A0 (Capoeira); as espécies da área de SAF mostraram-se eqüitativamente contribuindo para a diversidade (mostrando um alto grau de eqüabilidade), enquanto que, na área de Capoeira, houve predomínio de algumas espécies, principalmente da família Melastomataceae, característica de áreas degradadas ou em início de sucessão; 
4. O SAF de alta diversidade e dirigido pela sucessão natural testado mostrou-se muito eficiente para a recuperação de solos degradados;

5. O manejo adotado nesse SAF contribuiu para uma ciclagem e uso mais eficientes dos nutrientes, acarretando aumento dos teores de nutrientes disponíveis no solo;

6. A qualidade da serapilheira teve estreita relação (diretamente proporcional) com os teores de nutrientes no solo;

7. A prática da poda do componente vegetal nesse SAF, favorecendo o bombeamento de nutrientes e disponibilizando matéria orgânica fresca, de alta qualidade, foi responsável pela elevação dos níveis de nutrientes na serapilheira e nas camadas superficiais do solo, principalmente de fósforo, pela ativação da atividade da biota edáfica;

8. A adição de cálcio e magnésio pela calagem, nutrientes estes que permanecem no sistema pela ciclagem biogeoquímica intensa proporcionada pela prática de manejo, pode ter contribuído decisivamente para o aumento da fertilidade do solo, com aumento do $\mathrm{pH}$, disponibilização de $\mathrm{P}$, aumento do $\mathrm{V} \%$ e condicionamento de intensa atividade da biota edáfica. 


\section{ANEXOS}

ANEXO A - Fisionomia da área manejada (Al2), durante a coleta dos dados (março de 1997), em Ituberá, Bahia, Brasil.

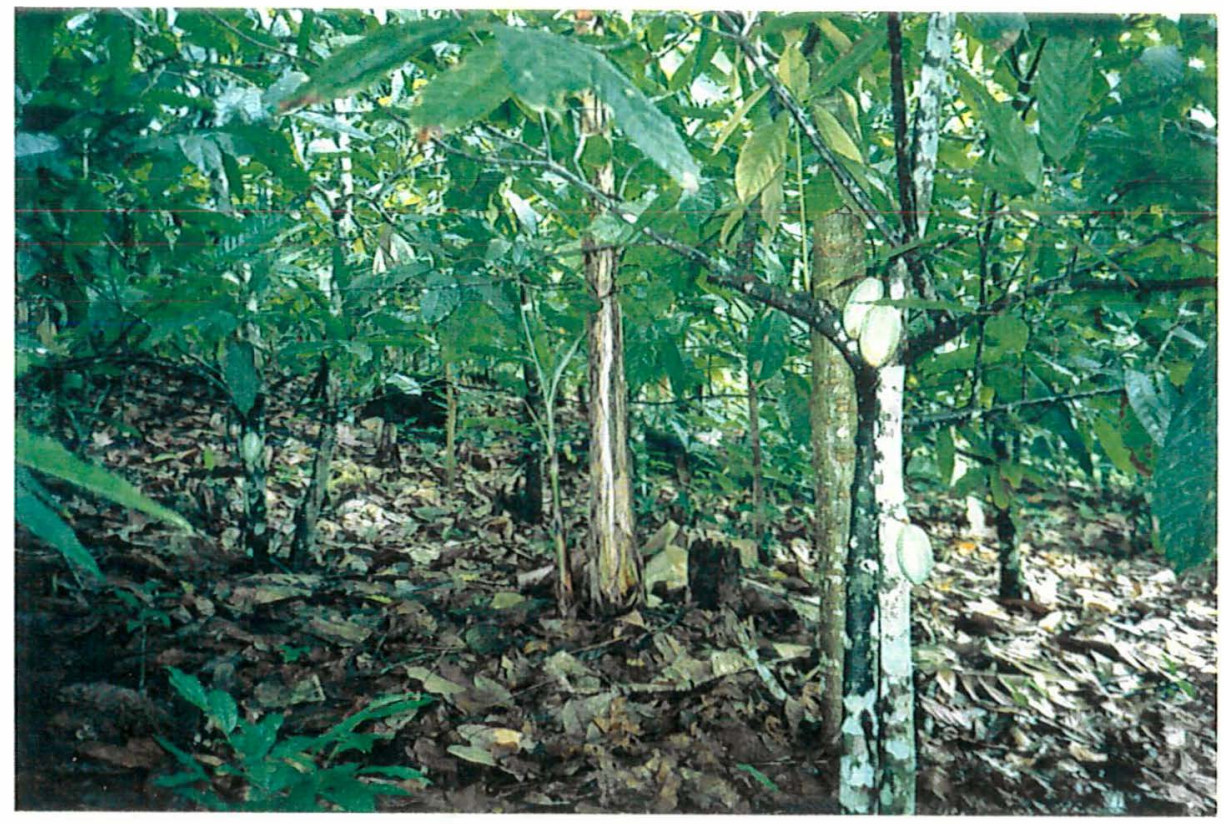

ANEXO B - Fisionomia da área de Capoeira (A0), durante a coleta dos dados (março de 1997), em Ituberá, Bahia, Brasil.

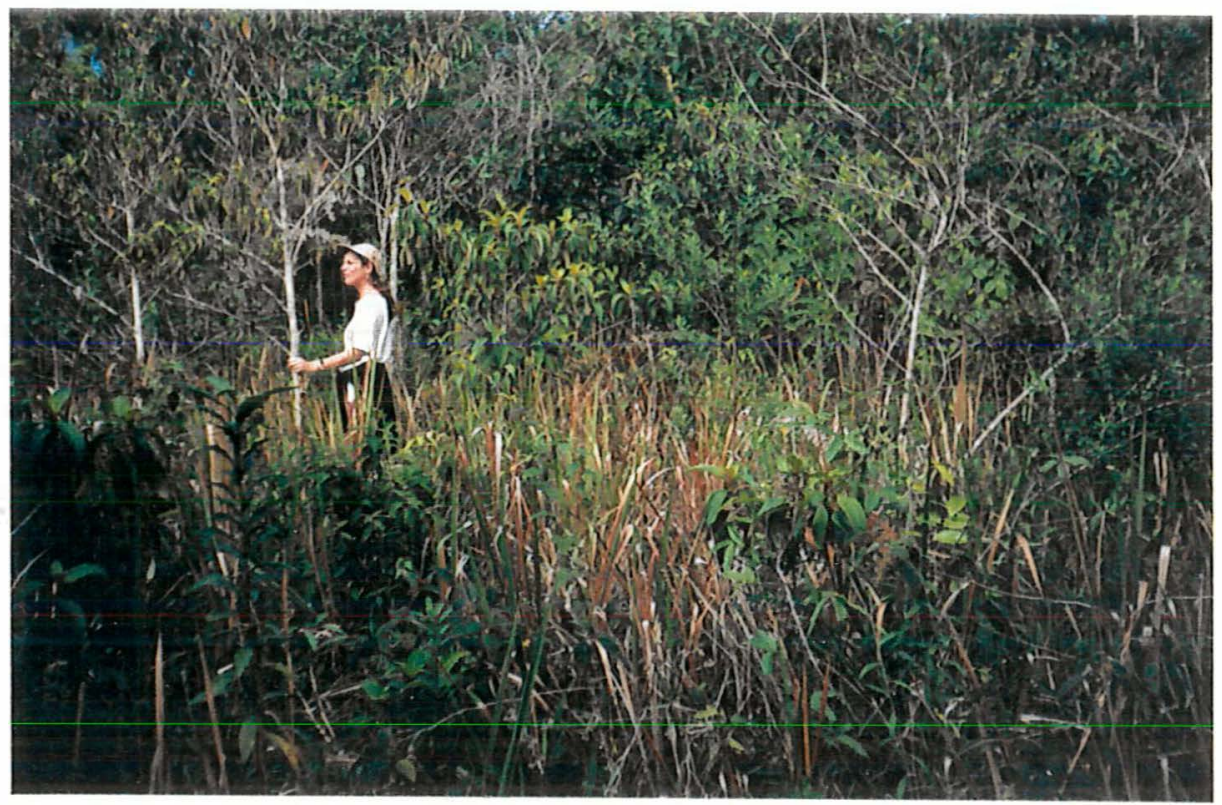


ANEXO C - Valores referentes à análise química para os horizontes dos perfis das duas trincheiras abertas na A0 (Capoeira) e A12 (SAF), município de Ituberá, Bahia, Brasil.

\begin{tabular}{|c|c|c|c|c|c|c|c|c|c|c|c|c|c|c|c|c|}
\hline Área & Iorizonte & Prof. $(\mathrm{cm})$ & $\begin{array}{c}\mathrm{pH} \\
\mathrm{H} 2 \mathrm{O} \\
\end{array}$ & $\begin{array}{l}\mathrm{pH} \\
\mathrm{KCl}\end{array}$ & $\begin{array}{c}\mathrm{pH} \\
\mathrm{CaCl} 2 \\
\end{array}$ & M.O & $\mathrm{P}$ & K & $\mathrm{Ca}$ & $\begin{array}{l}\mathrm{Mg} \\
\text { Imol }\end{array}$ & & $\mathrm{H}+\mathrm{Al}$ & SB & $\mathrm{T}$ & V\% & $\mathrm{m} \%$ \\
\hline AO & A & $0-0,17$ & 5,5 & 4,5 & 4,3 & 15 & 5 & 0,6 & 10 & 9 & 5 & 64 & 19,6 & 83,6 & 23 & 20 \\
\hline AO & $A B$ & $0,17-0,28$ & 5,5 & 4,5 & 4 & 38 & 3 & 0,4 & 2 & 2 & 15 & 110 & 4,4 & 114,4 & 4 & 77 \\
\hline $\mathrm{AO}$ & B1 & $0,28-0,56$ & 5,4 & 4,6 & 4,2 & 26 & 2 & 0,3 & 6 & 2 & 7 & 80 & 8,3 & 88,3 & 9 & 46 \\
\hline 40 & Bw1 & $0,56-2,00$ & 5,4 & 4,6 & 4,3 & 13 & 2 & 0,4 & 7 & 3 & 6 & 50 & 10,4 & 60,4 & 17 & 37 \\
\hline $\mathrm{AO}$ & Bw & $2,00-$ & 5,4 & 5 & 4,8 & 10 & 2 & 0,2 & 2 & 2 & 1 & 22 & 4,2 & 26,2 & 16 & 19 \\
\hline A12 & $A$ & $0-0$ & 5,6 & 5,2 & 5 & 59 & 13 & 1,4 & 74 & 55 & 0 & 46 & 130,4 & 176,4 & 74 & 0 \\
\hline 412 & $A B$ & $0,11-0,2$ & 4,9 & 4,2 & 4,1 & 31 & 4 & 0,6 & 9 & 7 & 8 & 68 & 16,6 & 84,6 & 20 & 33 \\
\hline A12 & B1 & $0,20-0,46$ & 5,1 & 4,4 & 4,1 & 18 & 1 & 0,4 & 4 & 4 & 7 & 54 & 8,4 & 62,4 & 13 & 45 \\
\hline A12 & Bw1 & $0,46-1,55$ & 5,2 & 4,5 & 4,2 & 18 & 2 & 0,1 & 3 & 1 & 6 & 50 & 4,1 & 54,1 & 8 & 59 \\
\hline A12 & Bw & $1,55-2,4$ & 4,8 & 4,8 & 4,5 & 13 & 1 & 0,2 & 4 & 2 & 6 & 40 & 6,2 & 46,2 & 13 & 49 \\
\hline
\end{tabular}

ANEXO D - Valores referentes à análise fỉsica para os horizontes dos perfis das duas trincheiras abertas na A0 (Capoeira) e A12 (SAF), município de Ituberá, Bahia, Brasil.

\begin{tabular}{lllcccc}
\hline Área & \multicolumn{1}{c}{ prof. } & Horizonte & $\%$ areia & $\%$ silte & $\%$ argila & classe de textura \\
\hline A0 & $0-0,17$ & A & 42 & 6 & 52 & arg. \\
A0 & $0,17-0,28$ & AB & 36 & 4 & 60 & m.arg. \\
A0 & $0,28-0,56$ & B1 & 24 & 4 & 72 & m.arg. \\
A0 & $0,56-2,00$ & Bw1 & 22 & 4 & 74 & m.arg. \\
A0 & $2,00-2,4$ & Bw & 20 & 2 & 78 & m.arg. \\
A12 & $0-0,11$ & A & 39 & 6 & 55 & arg. \\
A12 & $0,11-0,20$ & AB & 27 & 6 & 67 & m.arg. \\
A12 & $0,23-0,46$ & B1 & 23 & 6 & 67 & m.arg. \\
A12 & $0,46-1,55$ & Bw1 & 20 & 2 & 78 & m.arg. \\
A12 & $1,55-2,4$ & Bw & 21 & 4 & 75 & m.arg. \\
\hline
\end{tabular}

ANEXO E - Valores de densidade para três profundidades do solo, para as duas áreas estudadas (A0 - Capoeira e A12 - SAF), município de Ituberá, Bahia, Brasil.

\begin{tabular}{cccc}
\hline & \multicolumn{3}{c}{ densidade relativa das particulas $(\mathrm{g} / \mathrm{cm} 3)$} \\
\hline & prof. $0-5$ & prof. $5-20$ & prof. $40-60$ \\
A0 & 2.5 & 2.53 & 2.35 \\
A12 & 2.5 & 2.56 & 2.38 \\
\hline
\end{tabular}


ANEXO F - Identificação botânica das espécies arbóreas (com DAP $\geq 5 \mathrm{~cm}$ ), coletadas na A12 (SAF), município de Ituberá, Bahia, Brasil, seguidas de seus respectivos nomes populares

\begin{tabular}{|c|c|c|}
\hline Família & Espécie & Nome popular \\
\hline ANACARDIACEAE & Tapirira guianensis Aubl. & Pau-pombo \\
\hline ANNONACEAE & Guatteria australis A.St.-Hil. & Pindaiba preta \\
\hline ANONNACEAE & Guatteria odontopetala Mart. in Mart. & Pindaíba \\
\hline APOCYNACEAE & Aspidospermae spl & \\
\hline APOCYNACEAE & Himatanthus sucuuba (Spruce) Woodson & Janaúba \\
\hline APOCYNACEAE & Tabernaemontana laeta Mart. & Leiteiro/Pau-de-cachimbo \\
\hline AQUIFOLIACEAE & Ilex sp. & Gendiba verdadeira \\
\hline ARALIACEAE & Didimopanax morototonii (Aubl.) Decne. \& Planch. & Matatauba \\
\hline BORAGINACEAE & Cordia magnolioefolia Cham. & Baba de boi \\
\hline BORAGINACEAE & Cordia spl & Piti-cobra \\
\hline BORAGINACEAE & Cordia sp2 & \\
\hline CAESALPINIACEAE & Senna multijuga (Rich) H.S. Irwin \& Barneby & Cobi \\
\hline CHRISOBALANACEAE & Licania tomentosa (Benth.) Fritsch & \\
\hline CLUSIACEAE & Symphonia globulifera L. $f$. & Alandi \\
\hline ELAEOCARPACEAE & Sloanea obtusifolia (Moric.) K. Schum. & Gendiba preta \\
\hline EUPHORBIACEAE & Mabea fistulifera Mart. & Cabo-de-cachimbo \\
\hline EUPHORBIACEAE & Pera ferruginea (Schott.) Baill. & Cocão \\
\hline EUPHORBIACEAE & Pera glabrata (Schott.) Baill. & $\begin{array}{l}\text { Sete-cascos/pau-d'óleo- } \\
\text { branco }\end{array}$ \\
\hline EUPHORBIACEAE & Joanesia princips Vell. & Dandá* \\
\hline FABACEAE & Diplotrops incexis Rizz \& Matt & Sucupira marreta \\
\hline FABACEAE & Erytrina poeppigiana (Walp.) O.F.Cook & Eritrina* $^{*}$ \\
\hline FABACEAE & Clitoria fairchildiana $R A$. Howard & Sombreiro* \\
\hline FLACOURTIACEAE & Casearea spl & Fruta de Parari \\
\hline FLACOURTIACEAE & Carpotroche brasiliensis (Radai) A. Gray & $\begin{array}{l}\text { Fede-Gongo/Fruto-de- } \\
\text { paca/Livro-de-boi }\end{array}$ \\
\hline ICACINACEAE & Emmotum nitens (Benth.) Miers. & Aderno da praia \\
\hline LAURACEAE & Licariaguianensis Aubl. & Louro folhão \\
\hline LAURACEAE & Nectandra grandiflora Nees & Louro focinho-de-porco \\
\hline LAURACEAE & Nectandra lanceolata Nees & Louro catinga \\
\hline LAURACEAE & Nectandra leucantha Nees & Louro sabão \\
\hline LAURACEAE & Ocotea spl & \\
\hline LAURACEAE & Persea aerata & \\
\hline LAURACEAE & Persea americana & Abacateiro* \\
\hline LAURACEAE 1 & Indet & \\
\hline LAURACEAE 2 & Indet & \\
\hline LECYTHIDACEAE & Eschweileria tetrapetala Mori & Inhaíba vermelha* \\
\hline LECYTHIDACEAE & Eschweileria spl & Inhaíba branca \\
\hline LECYTHIDACEAE & Eschweileria ovata (Cambers) Miers & Biriba \\
\hline LECYTHIDACEAE & Lecvthis lurida (Miers) Mori & Inhaiba-gigante \\
\hline MELIACEAE & Cedrella aff. Huberii Ducke & Ingá-uçu branca \\
\hline MIMOSACEAE & Inga blanchetiana Benth & Ingá-de-metro* \\
\hline MIMOSACEAE & Inga thibaudiana $D C$. & Ingá-de-terra-seca \\
\hline MONIMIACEAE & Siparuna guianensis Aubl. & \\
\hline MORACEAE & Artocarpus heterophyllus Lam. & Jaqueira* \\
\hline MORACEAE & Coussapoa microcarpa (Schott.) Rizz & \\
\hline
\end{tabular}




\begin{tabular}{|l|l|l|}
\hline Familia & Espécie & Nome popular \\
\hline MYRTACEAE & Eugenia rideliana O. Berg & Murta \\
\hline MYRTACEAE & Gomidesia langsdorfii & Murta \\
\hline RUBIACEAE & Psychotria mapoureoides DC. & Ceboleiro \\
\hline RUBIACEAE & Alseis floribunda Schott & Macaco perema \\
\hline RUBIACEAE 1 & Indet. & \\
\hline RUTACEAE & Citrus limettioides Tanaka & Lima* \\
\hline SAPINDACEAE & Matoyba juglandifolia Randlk & Gravatá \\
\hline SAPOTACEAE & Pouteria guianensis Aublet & Macaco/Guapeba \\
\hline SAPOTACEAE & Pouteria bangii Rusby) Penningtoso & Macaco preto \\
\hline SOLANACEAE & Cestrum laevigatum Schltdl. & Coarana \\
\hline STERCULIACEAE & Theobroma bicolor Humb.\&Bompl. & Pataste* \\
\hline VERBENACEAE & Aegephyla selowiana Cham. & Fidalgo \\
\hline indeterminada & Indet. & \\
\hline
\end{tabular}

* Plantas introduzidas

ANEXO G - Identificação botânica das espécies arbóreas (com DAP $\geq 5 \mathrm{~cm}$ ), coletadas na A0 (Capoeira), município de Ituberá, Bahia, Brasil, seguidas de seus respectivos nomes populares

\begin{tabular}{|c|c|c|}
\hline Família & Espécie & Nome popular \\
\hline ANARCADIACEAE & Tapirira guianensis Aubl. & Pau-pombo \\
\hline ANONNACEAE & Guatteria gomeziana A.St.-Hil. & Banha-de-galinha \\
\hline ANONNACEAE & Xylopia frutescens Aubl. & Pindaíba-cominho \\
\hline APOCYNACEAE & Tabernaemontana salzmanii & Leiteiro \\
\hline APOCYNACEAE & Himatanthus sucuuba (Spruce) Woodson & Janaúba \\
\hline ARALIACEAE & Didimopanax morototonii (A ubl.) Decne. \& Planch. & Matatauba/Mandiocão \\
\hline ARECACEAE & Bactris spl & Tucum \\
\hline ARECACEAE & Syagrus pseudo-cocos Becc. & Pati \\
\hline ASTERACEAE & Vernonia diffusa Less. & Fumo-bravo da mata \\
\hline BIGNONIACEAE & Tabebuia heptaphilla (Vell.) Toledo & Pau d'arco rosa \\
\hline BOMBACACEAE & Bombax macrophvllum K Schum. & Imbiruçu* \\
\hline BORAGINACEAE & Cordia aff. sellowiana Cham. & Capote \\
\hline BURSERACEAE & Protium sp. & Amescoçu* \\
\hline CAESALPINIACEAE & Arapatiella pisilophila (Harms.) Cowam & Quiri \\
\hline CAESALPINIACEAE & Bauhinia spl & Unha-de-vaca \\
\hline CAESALPINIACEAE & Senna multijuga (Rich.) H.S. Irwin \& Barneby & Cobi \\
\hline CAESALPINIACEAE & Senna spl & \\
\hline CECROPIACEAE & Cecropia spl & Embauba-preta \\
\hline CECROPIACEAE & Cecropia sp2 & Embauba-vermelha \\
\hline CECROPIACEAE & Pourouma spl & Tararanga \\
\hline CLETHRACEAE & Clethra scabra Pers. & Abacateiro \\
\hline CLUSIACEAE & Vismia guianensis Choisy & Capianguinha \\
\hline CLUSIACEAE & Symphonia globulifera L.f. & Alandi \\
\hline CUNONIACEAE & Lamanonia ternata Vell. & Bejuim \\
\hline ELAEOCARPACEAE & Sloanea guianensis (Aubl.) Benth. & Cajueiro* \\
\hline ELAEOCARPACEAE & Sloanea spl & Cocão \\
\hline EUPHORBIACEAE & Mabea fistulifera Mart. & Cabo-de-cachimbo \\
\hline EUPHORBIACEAE & Aparisthmium cordatum (A.Juss.) Baill. & Lava-prato branco \\
\hline EUPHORBIACEAE & Alchornea iricurana Casar. & Lava-prato roxo \\
\hline
\end{tabular}




\begin{tabular}{|c|c|c|}
\hline Familia & Espécie & Nome popular \\
\hline FABACEAE & Andira vermifuga Mart. ex Benth. & Amargoso* \\
\hline FABACEAE & Ormosia spl & \\
\hline FLACOURTIACEAE & Casearea decandra Jacq. & Gravatazinho \\
\hline ICACINACEAE & Emmotum nitens (Benth.) Miers. & Aderno* \\
\hline LACISTEMATACEAE & Lacistema sp. & \\
\hline LAURACEAE & Nectandra leucantha Nees & Louro-sabão \\
\hline LAURACEAE & Nectandraspl & Louro-graveto \\
\hline LAURACEAE & Nectandra grandiflora Nees et Mart & \\
\hline LAURACEAE & Ocotea spl & Louro-casca-preta* \\
\hline LECYTHIDACEAE & Escheweilera tetrapetala Mori & Inhaiba vermelha \\
\hline MALPIGHIACEAE & Byrsonima spl & Murici branco \\
\hline MALPIGHIACEAE & Byrsonima sp2 & \\
\hline MELASTOMATACEAE & Tibouchina luetzelbergii Mark Gr. & Piqui-de-capoeira \\
\hline MELASTOMATACEAE & Miconia calvescens D.C & Mundururu-vermelho \\
\hline MELASTOMATACEAE & Miconia ruficalyx Gleason & Mundururu-branco \\
\hline MELASTOMATACEAE & Miconia hypoleuca (Benth) Triana & Mundururu-preto \\
\hline MELASTOMATACEAE & Miconia pyrufolia Newdin & \\
\hline MELASTOMATACEAE & Miconia mirabilis (Aubl) L.O..Willians & Mundururu-de-rego \\
\hline MELASTOMATACEAE & Henriettea succosa (subl.) D.C. & Mundururu-ferro \\
\hline MELIACEAE & Trichilia quadrijuga Kunth & Rosa-branca* \\
\hline MIMOSACEAE & Inga capitata Desv. & Tapaúna* \\
\hline MORACEAE & Coussapoa spl & Macaco-canela-de-cotia* \\
\hline MORACEAE & Brosimum lactescens (S.Moore) C.C. Berg & \\
\hline MORACEAE & Helicostylis tomentosa (Poepp. \& Endl.) Rusby & Amora-preta* \\
\hline MYRSINACEAE & Rapanea ferruginea (Ruiz \& Pav.) Mez & Pororoca \\
\hline MYRTACEAE & Myrcia sp. & Murta-de-capoeira \\
\hline NYCTAGINACEAE & Guapira opposita (Vell.) Reitz & João-dormindo \\
\hline RUBIACEAE & Redgea vellerea Müll Arg. & \\
\hline RUTACEAE & indet & Laranjeira* \\
\hline SAPINDACEAE & Allophylus petiolulatus Radlkofer & \\
\hline SAPINDACEAE & Cupanea racemosa Radlk. & Cambotá \\
\hline SAPINDACEAE & Dictolonia vandellianium A. Juss. & Arruda-do-mato \\
\hline SAPOTACEAE & Pouteria guianensis & \\
\hline TILIACEAE & Apeiba tibourbou Aubl. & Jangada \\
\hline VERBENACEAE & Vitex orinocensis Kunth & Perema \\
\hline VOCHISIACEAE & Vochysia haenkeana Mart. & Vai-na-vila \\
\hline VOCHISIACEAE & Qualea wittrockii & Mencha do mato \\
\hline INDET 1 & Indet & \\
\hline INDET 2 & Indet & \\
\hline INDET 3 & Indet & \\
\hline INDET 4 & Indet & \\
\hline INDET 5 & Indet & \\
\hline INDET 6 & Indet & \\
\hline INDET 7 & Indet & \\
\hline INDET 8 & Indet & \\
\hline
\end{tabular}

* Plantas consideradas pelo mateiro como sendo de mata (capoeira alta). Provavelmente são exemplares remanescentes da mata que ali estavam antes da exploração. 
ANEXO H - Dados fitossociológicos da área de Capoeira (A0)

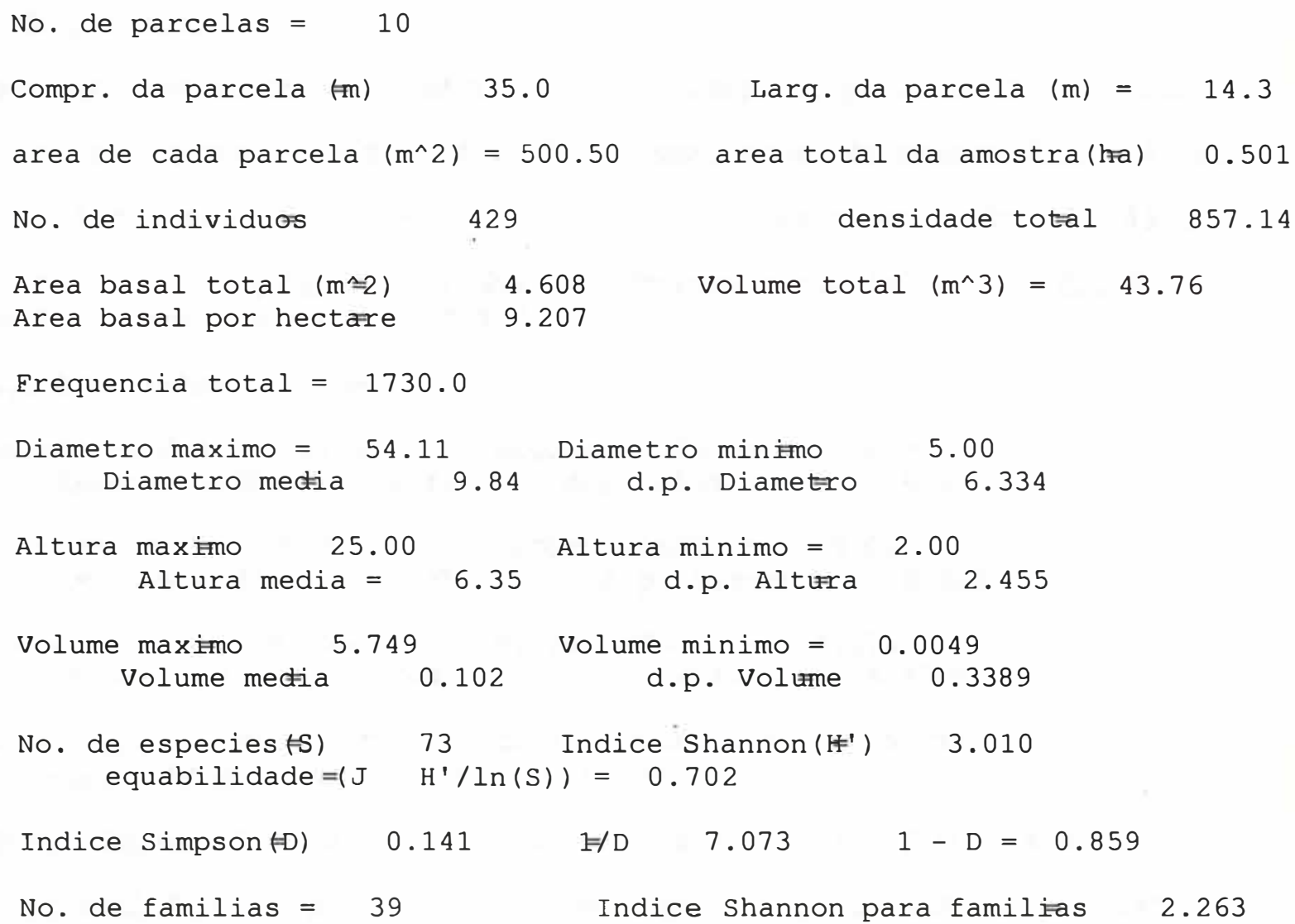

\begin{tabular}{|c|c|c|c|c|c|c|}
\hline especie & No. Ind & No. Amo & Dens.Re & Dom. Rel & Freq. Re & IVI \\
\hline Tibouchina luetzelbergii..... & 152 & 10 & 35.43 & 32.52 & 5.78 & 73.73 \\
\hline Henriettea succosa........... & 31 & 6 & 7.23 & 6.87 & 3.47 & 17.57 \\
\hline Nectandra sp.1............ & 5 & 3 & 1.17 & 9.57 & 1.73 & 12.47 \\
\hline Vernonia diffusa............. & 22 & 9 & 5.13 & 1.71 & 5.20 & 12.04 \\
\hline 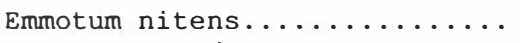 & 7 & 5 & 1.63 & 6.55 & 2.89 & 11.07 \\
\hline Syagrus pseudo-cocos......... & 19 & 7 & 4.43 & 2.57 & 4.05 & 11.04 \\
\hline Miconia mirabilis............ & 23 & 6 & 5.36 & 1.46 & 3.47 & 10.29 \\
\hline Mabea fistulifera............. & 10 & 6 & 2.33 & 1.91 & 3.47 & 7.71 \\
\hline Bactris sp.............. & 13 & 6 & 3.03 & 1.11 & 3.47 & 7.61 \\
\hline Tapirira guianensis.......... & 11 & 5 & 2.56 & 2.07 & 2.89 & 7.53 \\
\hline Alchornea iric & 10 & 4 & 2.33 & 1.49 & 2.3 & 6.13 \\
\hline Guapira opposita........... & 7 & 3 & 1.63 & 1.94 & 1.73 & 5.30 \\
\hline Himatanthus sucuuba........... & 6 & 5 & 1.40 & 0.53 & 2.89 & 4.82 \\
\hline Vochysia haenkeana........... & 3 & 2 & 0.70 & 2.79 & 1.16 & 4.65 \\
\hline Trichilia quadrijuga.......... & 2 & 2 & 0.47 & 2.92 & 1.16 & 4.55 \\
\hline Cecropia sp $2 \ldots \ldots \ldots \ldots \ldots \ldots$ & 6 & 4 & 1.40 & 0.38 & 2.31 & 4.09 \\
\hline Bombax macrophyllum.......... & 2 & 2 & 0.47 & 2.41 & 1.16 & 4.03 \\
\hline Aparisthmium cordatum........ & 3 & 3 & 0.70 & 1.55 & 1.73 & 3.98 \\
\hline Didymopanax morototoni....... & 4 & 4 & 0.93 & 0.52 & 2.31 & 3.77 \\
\hline Rapanea ferruginea........... & 5 & 4 & 1.17 & 0.25 & 2.31 & 3.73 \\
\hline & 4 & & 0.93 & 0.47 & 2.31 & 3.72 \\
\hline lethra sc & 3 & 3 & 0.70 & 0.76 & 1.73 & 3.20 \\
\hline lectandra leucant & 3 & 3 & 0.70 & 0.54 & 1.73 & 2.97 \\
\hline
\end{tabular}




\begin{tabular}{|c|c|c|c|c|c|c|}
\hline Cordia aff sellowiana........ & 3 & 3 & 0.70 & 0.47 & 1.73 & 2.91 \\
\hline Vismia guianensis............ & 4 & 3 & 0.93 & 0.20 & 1.73 & 2.86 \\
\hline Miconia ruficalyx............ & 5 & 2 & 1.17 & 0.46 & 1.16 & 2.78 \\
\hline Lamononia ternata............ & 3 & 2 & 0.70 & 0.68 & 1.16 & 2.54 \\
\hline Rutaceae $1 \ldots \ldots \ldots \ldots \ldots$ & 1 & 1 & 0.23 & 1.49 & 0.58 & 2.30 \\
\hline Sloanea guianensis........... & 1 & 1 & 0.23 & 1.45 & 0.58 & 2.26 \\
\hline Byrsonima sp $1 \ldots \ldots \ldots \ldots \ldots$ & 2 & 2 & 0.47 & 0.62 & 1.16 & 2.25 \\
\hline 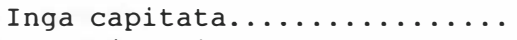 & 3 & 2 & 0.70 & 0.28 & 1.16 & 2.14 \\
\hline Cecropia spl............ & 2 & 2 & 0.47 & 0.51 & 1.16 & 2.13 \\
\hline Helicostylis tomentosa....... & 3 & 2 & 0.70 & 0.20 & 1.16 & 2.06 \\
\hline Miconia hypoleuca........... & 3 & 2 & 0.70 & 0.20 & 1.16 & 2.05 \\
\hline Ocotea sp $2 \ldots \ldots \ldots \ldots \ldots \ldots$ & 2 & 1 & 0.47 & 0.97 & 0.58 & 2.01 \\
\hline Eschweilera tetrapetala...... & 2 & 2 & 0.47 & 0.30 & 1.16 & 1.92 \\
\hline Xylopia frutescens........... & 2 & 2 & 0.47 & 0.24 & 1.16 & 1.86 \\
\hline Dictiolona vandellianium...... & 2 & 2 & 0.47 & 0.22 & 1.16 & 1.85 \\
\hline Senna multijuga............ & 1 & 1 & 0.23 & 0.99 & 0.58 & 1.80 \\
\hline Myrcia sp................ & 2 & 2 & 0.47 & 0.15 & 1.16 & 1.78 \\
\hline indet $.8 \ldots \ldots \ldots \ldots \ldots \ldots \ldots$ & 1 & 1 & 0.23 & 0.96 & 0.58 & 1.77 \\
\hline 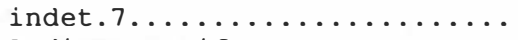 & 2 & 2 & 0.47 & 0.14 & 1.16 & 1.76 \\
\hline Andira vermifuga $\ldots \ldots \ldots \ldots \ldots$ & 2 & 2 & 0.47 & 0.12 & 1.16 & 1.74 \\
\hline Lacistema sp. $\ldots \ldots \ldots \ldots \ldots \ldots$ & 1 & 1 & 0.23 & 0.89 & 0.58 & 1.70 \\
\hline Arapatiela pisilophila........ & 1 & 1 & 0.23 & 0.81 & 0.58 & 1.62 \\
\hline Qualea wittrockii........... & 1 & 1 & 0.23 & 0.80 & 0.58 & 1.61 \\
\hline Casearia decandra............ & 1 & 1 & 0.23 & 0.53 & 0.58 & 1.34 \\
\hline Symphonia globulifera......... & 1 & 1 & 0.23 & 0.44 & 0.58 & 1.25 \\
\hline Tabernaemontana salzmanii..... & 2 & 1 & 0.47 & 0.21 & 0.58 & 1.25 \\
\hline 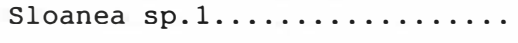 & 1 & 1 & 0.23 & 0.42 & 0.58 & 1.23 \\
\hline 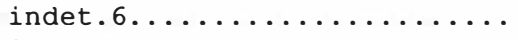 & 1 & 1 & 0.23 & 0.38 & 0.58 & 1.19 \\
\hline 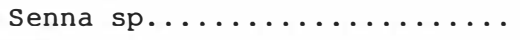 & 2 & 1 & 0.47 & 0.09 & 0.58 & 1.13 \\
\hline Byrsonima $\operatorname{sp} 2 \ldots \ldots \ldots \ldots \ldots$ & 1 & 1 & 0.23 & 0.28 & 0.58 & 1.09 \\
\hline Indet $4 \ldots \ldots \ldots \ldots \ldots \ldots$ & 1 & 1 & 0.23 & 0.24 & 0.58 & 1.05 \\
\hline Coussapoa sp.............. & 1 & 1 & 0.23 & 0.20 & 0.58 & 1.01 \\
\hline Indet $5 \ldots \ldots \ldots \ldots \ldots \ldots \ldots$ & 1 & 1 & 0.23 & 0.10 & 0.58 & 0.91 \\
\hline Pourouma $\operatorname{sp} 1 \ldots \ldots \ldots \ldots \ldots \ldots$ & 1 & 1 & 0.23 & 0.09 & 0.58 & 0.90 \\
\hline Miconia pyrufolia........... & 1 & 1 & 0.23 & 0.08 & 0.58 & 0.89 \\
\hline Vitex orinocensis........... & 1 & 1 & 0.23 & 0.08 & 0.58 & 0.89 \\
\hline Guatteria gomeziana.......... & 1 & 1 & 0.23 & 0.08 & 0.58 & 0.89 \\
\hline Pouteria guianensis.......... & 1 & 1 & 0.23 & 0.07 & 0.58 & 0.88 \\
\hline indet. $1 \ldots \ldots \ldots \ldots \ldots \ldots \ldots$ & 1 & 1 & 0.23 & 0.07 & 0.58 & 0.88 \\
\hline Tabebuia heptaphylla......... & 1 & 1 & 0.23 & 0.07 & 0.58 & 0.88 \\
\hline indet. $3 \ldots \ldots \ldots \ldots \ldots \ldots$ & 1 & 1 & 0.23 & 0.07 & 0.58 & 0.88 \\
\hline Miconia calvescens........... & 1 & 1 & 0.23 & 0.06 & 0.58 & 0.87 \\
\hline Protium sp............. & 1 & 1 & 0.23 & 0.06 & 0.58 & 0.87 \\
\hline Cupania racenosa............. & 1 & 1 & 0.23 & 0.05 & 0.58 & 0.86 \\
\hline Allophylus petiolulatus....... & 1 & 1 & 0.23 & 0.05 & 0.58 & 0.86 \\
\hline Necantra grandiflora......... & 1 & 1 & 0.23 & 0.05 & 0.58 & 0.86 \\
\hline Apeiba tibourbou............ & 1 & 1 & 0.23 & 0.05 & 0.58 & 0.86 \\
\hline Brosimium lactescens.......... & 1 & 1 & 0.23 & 0.05 & 0.58 & 0.86 \\
\hline Ormosia sp.............. & 1 & 1 & 0.23 & 0.04 & 0.58 & 0.86 \\
\hline Bauhinia sp & 1 & 1 & 0.23 & 0.04 & 0.58 & 0.86 \\
\hline
\end{tabular}

\begin{tabular}{|c|c|c|c|c|}
\hline especie & IVC & Fre & Dens.Ab & Dom.Med. \\
\hline Tibouchina luetzelbergii...... & 67.95 & 100.00 & 303.7 & 0.0099 \\
\hline Henriettea succosa & 14.10 & 60.00 & 61.9 & 0.0102 \\
\hline Ara sp. & 10.73 & 30.00 & 10.0 & 0.0882 \\
\hline nia diff & 6.83 & 90.00 & 44.0 & 0.0036 \\
\hline Emmotum $n$ & 8.18 & 50.00 & 14.0 & 0.0431 \\
\hline Syagrus & 6.99 & 70.00 & 38.0 & 0.0062 \\
\hline Miconia mirabilis....... & 6.82 & 60.00 & 46.0 & 0.0029 \\
\hline Mabea fistulifera....... & 4.24 & 60.00 & 20.0 & 0.0088 \\
\hline
\end{tabular}




\begin{tabular}{|c|c|c|c|c|}
\hline 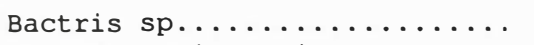 & 4.14 & 60.00 & 26.0 & 0.0040 \\
\hline Tapirira guianensis.......... & 4.64 & 50.00 & 22.0 & 0.0087 \\
\hline Alchornea iricurana.......... & 3.82 & 40.00 & 20.0 & 0.0068 \\
\hline Guapira opposita............ & 3.57 & 30.00 & 14.0 & 0.0128 \\
\hline imatanthus sucuuba.......... & 1.93 & 50.00 & 12.0 & 0.0041 \\
\hline Vochysia haenkeana........... & 3.49 & 20.00 & 6.0 & 0.0429 \\
\hline Trichilia quadrijuga.......... & 3.39 & 20.00 & 4.0 & 0.0674 \\
\hline Cecropia sp2............. & 1.78 & 40.00 & 12.0 & 0.0029 \\
\hline Bombax macrophyllum......... & 2.87 & 20.00 & 4.0 & 0.0555 \\
\hline Aparisthmium cordatum........ & 2.25 & 30.00 & 6.0 & 0.0238 \\
\hline Didymopanax morototoni....... & 1.46 & 40.00 & 8.0 & 0.0060 \\
\hline Rapanea ferruginea........... & 1.42 & 40.00 & 10.0 & 0.0023 \\
\hline Rudgea vellerea............. & 1.41 & 40.00 & 8.0 & 0.0055 \\
\hline Clethra scabra............... & 1.46 & 30.00 & 6.0 & 0.0117 \\
\hline Nectandra leucantha.......... & 1.24 & 30.00 & 6.0 & 0083 \\
\hline Cordia aff sellowiana........ & 1.17 & 30.00 & 6.0 & 0.0073 \\
\hline Vismia guianensis............ & 1.13 & 30.00 & 8.0 & 0.0023 \\
\hline Miconia ruficalyx............ & 1.63 & 20.00 & 10.0 & 0.0042 \\
\hline Lamononia ternata........... & 1.38 & 20.00 & 6.0 & 0.0105 \\
\hline Rutaceae $1 \ldots \ldots \ldots \ldots \ldots \ldots$ & 1.73 & 10.00 & 2.0 & 0.0688 \\
\hline Sloanea guianensis........... & 1.68 & 10.00 & 2.0 & 0.0666 \\
\hline Byrsonima sp $1 \ldots \ldots \ldots \ldots \ldots$ & 1.09 & 20.00 & 4.0 & 0.0144 \\
\hline 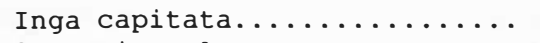 & 0.98 & 20.00 & 6.0 & 0.0043 \\
\hline Cecropia spl.............. & 0.98 & 20.00 & 4.0 & .0118 \\
\hline Helicostylis tomentosa....... & 0.90 & 20.00 & 6.0 & .0031 \\
\hline Miconia hypoleuca........... & 0.90 & 20.00 & 6.0 & .0030 \\
\hline Ocotea sp $2 \ldots \ldots \ldots \ldots \ldots \ldots$ & 1.44 & 10.00 & 4.0 & .0223 \\
\hline Eschweilera tetrapetala...... & 0.76 & 20.00 & 4.0 & 0.0069 \\
\hline Xylopia frutescens.......... & 0.70 & 20.00 & 4.0 & .0055 \\
\hline Dictiolona vandellianium...... & 0.69 & 20.00 & 4.0 & .0052 \\
\hline Senna multijuga............. & 1.22 & 10.00 & 2.0 & 0.0455 \\
\hline 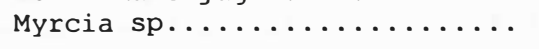 & 0.62 & 20.00 & 4.0 & 0.0036 \\
\hline$t .8 \ldots \ldots \ldots \ldots \ldots \ldots \ldots$ & 1.19 & 10.00 & 2.0 & \\
\hline indet $.7 \ldots \ldots \ldots \ldots \ldots \ldots \ldots$ & 0.61 & 20.00 & 4.0 & 032 \\
\hline Andira vermifuga............ & 0.59 & 20.00 & 4.0 & 0.0028 \\
\hline Lacistema sp.............. & 1.13 & 10.00 & 2.0 & 0.0411 \\
\hline Arapatiela pisilophila....... & 1.04 & 10.00 & 2.0 & 0.0373 \\
\hline Qualea wittrockii........... & 1.03 & 10.00 & 2.0 & .0368 \\
\hline Casearia decandra............ & .76 & 10.00 & 2.0 & 0.0243 \\
\hline Symphonia globulifera........ & .67 & 10.00 & 2.0 & 0.0203 \\
\hline Tabernaemontana salzmanii.... & 0.67 & 10.00 & 4.0 & 0.0047 \\
\hline sloanea sp.1.............. & 0.65 & 10.00 & 2.0 & 0.0192 \\
\hline indet. $6 \ldots \ldots \ldots \ldots \ldots \ldots$ & 0.61 & 10.00 & 2.0 & 0.0176 \\
\hline 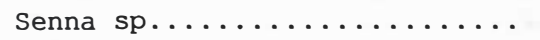 & 0.55 & 10.00 & 4.0 & 0.0020 \\
\hline Byrsonima sp $2 \ldots \ldots \ldots \ldots \ldots$ & 0.51 & 10.00 & 2.0 & 0.0129 \\
\hline Indet. $4 \ldots \ldots \ldots \ldots \ldots \ldots$ & 0.48 & 10.00 & 2.0 & 0.0112 \\
\hline Coussapoa sp............... & 0.43 & 10.00 & 2.0 & 0.0092 \\
\hline Indet $.5 \ldots \ldots \ldots \ldots \ldots \ldots \ldots$ & 0.33 & 10.00 & 2.0 & 0.0044 \\
\hline 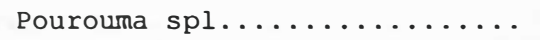 & 0.32 & 10.00 & 2.0 & 0.0040 \\
\hline Miconia pyrufolia........... & 0.32 & 10.00 & 2.0 & 0.0038 \\
\hline vitex orinocensis........... & 0.31 & 10.00 & 2.0 & 0.0037 \\
\hline Guatteria gomeziana.......... & 0.31 & 10.00 & 2.0 & 0.0035 \\
\hline Pouteria guianensis.......... & 0.31 & 10.00 & 2.0 & 0.0033 \\
\hline indet $1 \ldots \ldots \ldots \ldots \ldots \ldots$ & 0.30 & 10.00 & 2.0 & 0.0032 \\
\hline Tabebuia heptaphylla........ & 0.30 & 10.00 & 2.0 & 0.0032 \\
\hline indet $.3 \ldots \ldots \ldots \ldots \ldots \ldots$ & 0.30 & 10.00 & 2.0 & 0.0031 \\
\hline Miconia calvescens.......... & 0.30 & 10.00 & 2.0 & 0.0029 \\
\hline Protium $s$ & 0.29 & 10.00 & 2.0 & 0.0026 \\
\hline Cupania racenosa............ & 0.28 & 10.00 & 2.0 & 0.0023 \\
\hline Allophylus petiolulatus...... & 0.28 & 10.00 & 2.0 & 0.0023 \\
\hline War t & 0.28 & 10.00 & 2.0 & 0.0023 \\
\hline peiba tibourbou....... & 0.28 & 10.00 & 2.0 & 0.0022 \\
\hline
\end{tabular}




\begin{tabular}{|c|c|c|c|c|}
\hline Brosimium lactescens. & 0.28 & 10.00 & 2.0 & 0.0022 \\
\hline Ormosia sp.... & 0.28 & 10.00 & 2.0 & 0.0020 \\
\hline Bauhinia sp........... & 0.28 & 10.00 & 2.0 & 0.0020 \\
\hline
\end{tabular}

\begin{tabular}{|c|c|c|c|c|c|c|c|}
\hline familia & No. Ind & No.Spp & \&े Spp & Dens. Ab & Dom.Med. & Freq.Ab & Dens. Re \\
\hline Melastomataceae.... & 216 & 7 & 9.59 & 431.6 & 0.0089 & 100.00 & 50.35 \\
\hline Lauraceae.......... & 11 & 4 & 5.48 & 22.0 & 0.0466 & 60.00 & 2.56 \\
\hline Arecaceae......... & 32 & 2 & 2.74 & 63.9 & 0.0053 & 70.00 & 7.46 \\
\hline Euphorbiaceae....... & 23 & 3 & 4.11 & 46.0 & 0.0099 & 70.00 & 5.36 \\
\hline Asteraceae........ & 22 & 1 & 1.37 & 44.0 & 0.0036 & 90.00 & 5.13 \\
\hline Icacinaceae........ & 7 & 1 & 1.37 & 14.0 & 0.0431 & 50.00 & 1.63 \\
\hline Anacardiaceae....... & 11 & 1 & 1.37 & 22.0 & 0.0087 & 50.00 & 2.56 \\
\hline indeterminada....... & 8 & 7 & 9.59 & 16.0 & 0.0113 & 60.00 & 1.86 \\
\hline Cecropiaceae....... & 9 & 3 & 4.11 & 18.0 & 0.0050 & 60.00 & 2.10 \\
\hline Apocynaceae....... & 8 & 2 & 2.74 & 16.0 & 0.0043 & 60.00 & 1.86 \\
\hline Caesalpiniaceae..... & 5 & 4 & 5.48 & 10.0 & 0.0178 & 40.00 & 1.17 \\
\hline Vochysiaceae...... & 4 & 2 & 2.74 & 8.0 & 0.0414 & 20.00 & 0.93 \\
\hline Nyctaginaceae...... & 7 & 1 & 1.37 & 14.0 & 0.0128 & 30.00 & 1.63 \\
\hline Meliaceae.......... & 2 & 1 & 1.37 & 4.0 & 0.0674 & 20.00 & 0.47 \\
\hline Clusiaceae......... & 5 & 2 & 2.74 & 10.0 & 0.0059 & 40.00 & 1.17 \\
\hline Araliaceae......... & 4 & 1 & 1.37 & 8.0 & 0.0060 & 40.00 & 0.93 \\
\hline Myrsinaceae........ & 5 & 1 & 1.37 & 10.0 & 0.0023 & 40.00 & 1.17 \\
\hline Rubiaceae......... & 4 & 1 & 1.37 & 8.0 & 0.0055 & 40.00 & 0.93 \\
\hline Bombacaceae........ & 2 & 1 & 1.37 & 4.0 & 0.0555 & 20.00 & 0.47 \\
\hline Sapindaceae........ & 4 & 3 & 4.11 & 8.0 & 0.0037 & 40.00 & 0.93 \\
\hline Clethraceae........ & 3 & 1 & 1.37 & 6.0 & 0.0117 & 30.00 & 0.70 \\
\hline Boraginaceae....... & 3 & 1 & 1.37 & 6.0 & 0.0073 & 30.00 & 0.70 \\
\hline Annonaceae......... & 3 & 2 & 2.74 & 6.0 & 0.0048 & 30.00 & 0.70 \\
\hline Moraceae.......... & 5 & 3 & 4.11 & 10.0 & 0.0042 & 20.00 & 1.17 \\
\hline Fabaceae.......... & 3 & 2 & 2.74 & 6.0 & 0.0025 & 30.00 & 0.70 \\
\hline Malpighiaceae...... & 3 & 2 & 2.74 & 6.0 & 0.0139 & 20.00 & 0.70 \\
\hline Elaeocarpaceae..... & 2 & 2 & 2.74 & 4.0 & 0.0429 & 10.00 & 0.47 \\
\hline Cunoniaceae........ & 3 & 1 & 1.37 & 6.0 & 0.0105 & 20.00 & 0.70 \\
\hline Mimosaceae........ & 3 & 1 & 1.37 & 6.0 & 0.0043 & 20.00 & 0.70 \\
\hline Rutaceae.......... & 1 & 1 & 1.37 & 2.0 & 0.0688 & 10.00 & 0.23 \\
\hline Lecythidaceae...... & 2 & 1 & 1.37 & 4.0 & 0.0069 & 20.00 & 0.47 \\
\hline Myrtaceae......... & 2 & 1 & 1.37 & 4.0 & 0.0036 & 20.00 & 0.47 \\
\hline Lacistemataceae..... & 1 & 1 & 1.37 & 2.0 & 0.0411 & 10.00 & 0.23 \\
\hline Flacourtiaceae..... & 1 & 1 & 1.37 & 2.0 & 0.0243 & 10.00 & 0.23 \\
\hline Verbenaceae........ & 1 & 1 & 1.37 & 2.0 & 0.0037 & 10.00 & 0.23 \\
\hline Sapotaceae......... & 1 & 1 & 1.37 & 2.0 & 0.0033 & 10.00 & 0.23 \\
\hline Bignoniaceae...... & 1 & 1 & 1.37 & 2.0 & 0.0032 & 10.00 & 0.23 \\
\hline Burseraceae........ & 1 & 1 & 1.37 & 2.0 & 0.0026 & 10.00 & 0.23 \\
\hline Tiliaceae........ & 1 & 1 & 1.37 & 2.0 & 0.0022 & 10.00 & 0.23 \\
\hline
\end{tabular}

\begin{tabular}{|c|c|c|c|}
\hline familia & Dom. Rel & Freq. Re & IV I \\
\hline Melastomataceae..... & 41.66 & 7.52 & 99.53 \\
\hline Lauraceae........... & 11.13 & 4.51 & 18.20 \\
\hline Arecaceae.......... & 3.68 & 5.26 & 16.40 \\
\hline Euphorbiaceae....... & 4.94 & 5.26 & 15.57 \\
\hline Asteraceae......... & 1.71 & 6.77 & 13.60 \\
\hline Icacinaceae........ & 6.55 & 3.76 & 11.94 \\
\hline Anacardiaceae...... & 2.07 & 3.76 & 8.40 \\
\hline indeterminada...... & 1.95 & 4.51 & 8.33 \\
\hline Cecropiaceae....... & 0.98 & 4.51 & 7.59 \\
\hline Apocynaceae........ & 0.74 & 4.51 & 7.12 \\
\hline Caesalpiniaceae. . & 1.93 & 3.01 & 6.10 \\
\hline
\end{tabular}




\begin{tabular}{|c|c|c|c|}
\hline Vochysiaceae.. & 3.59 & 1.50 & 6.03 \\
\hline Nyctaginaceae...... & 1.94 & 2.26 & 5.83 \\
\hline Meliaceae......... & 2.92 & 1.50 & 4.89 \\
\hline Clusiaceae.......... & 0.64 & 3.01 & 4.81 \\
\hline Araliaceae......... & 0.52 & 3.01 & 4.46 \\
\hline Myrsinaceae........ & 0.25 & 3.01 & 4.43 \\
\hline Rubiaceae......... & 0.47 & 3.01 & 4.41 \\
\hline Bombacaceae........ & 2.41 & 1.50 & 4.38 \\
\hline Sapindaceae........ & 0.32 & 3.01 & 4.26 \\
\hline Clethraceae........ & 0.76 & 2.26 & 3.72 \\
\hline Boraginaceae....... & 0.47 & 2.26 & 3.43 \\
\hline Annonaceae......... & 0.31 & 2.26 & 3.27 \\
\hline Moraceae.......... & 0.45 & 1.50 & 3.12 \\
\hline Fabaceae.......... & 0.16 & 2.26 & 3.12 \\
\hline Malpighiaceae...... & 0.90 & 1.50 & 3.11 \\
\hline Elaeocarpaceae..... & 1.86 & 0.75 & 3.08 \\
\hline Cunoniaceae........ & 0.68 & 1.50 & 2.88 \\
\hline Mimosaceae......... & 0.28 & 1.50 & 2.49 \\
\hline Rutaceae............... & 1.49 & 0.75 & 2.48 \\
\hline Lecythidaceae....... & 0.30 & 1.50 & 2.27 \\
\hline Myrtaceae.......... & 0.15 & 1.50 & 2.12 \\
\hline Lacistemataceae..... & 0.89 & 0.75 & 1.88 \\
\hline Elacourtiaceae...... & 0.53 & 0.75 & 1.51 \\
\hline Verbenaceae........ & 0.08 & 0.75 & 1.06 \\
\hline Sapotaceae........ & 0.07 & 0.75 & 1.06 \\
\hline Bignoniaceae...... & 0.07 & 0.75 & 1.05 \\
\hline Burseraceae........ & 0.06 & 0.75 & 1.04 \\
\hline Tiliaceae.......... & 0.05 & 0.75 & 1.03 \\
\hline
\end{tabular}

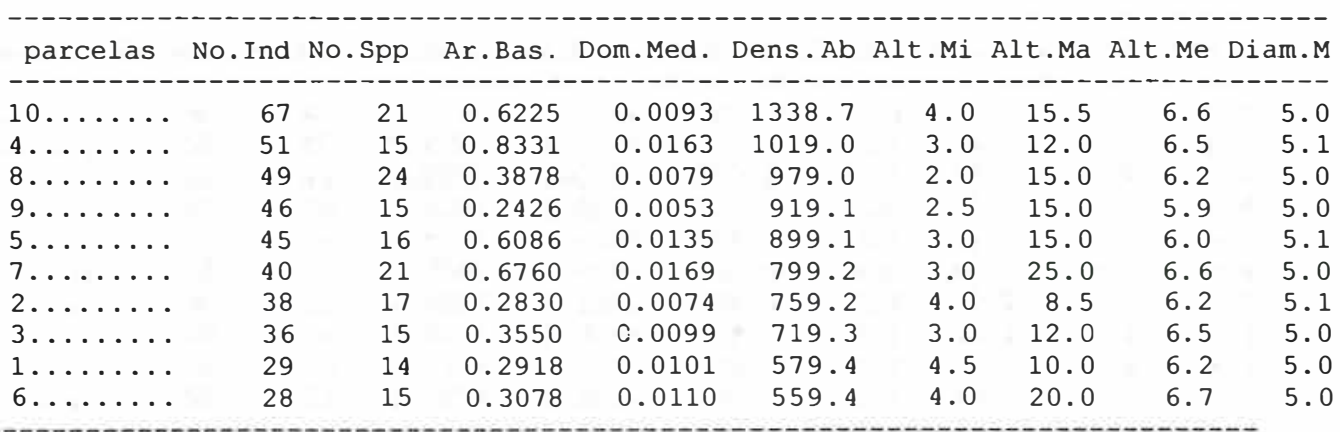

\begin{tabular}{|c|c|}
\hline parcelas & Diam.M \\
\hline $10 \ldots \ldots$ & 36.4 \\
\hline $4 \ldots \ldots \ldots$ & 44.7 \\
\hline $8 \ldots \ldots \ldots$ & 29.3 \\
\hline $9 \ldots \ldots \ldots$ & 23.7 \\
\hline $5 \ldots \ldots$ & 29.0 \\
\hline $7 \ldots \ldots \ldots$ & 54.1 \\
\hline $2 \ldots \ldots \ldots$ & 26.1 \\
\hline $3 \ldots \ldots$ & 23.2 \\
\hline $1 \ldots \ldots \ldots$ & 29.6 \\
\hline $6 \ldots \ldots \ldots$ & 29.6 \\
\hline
\end{tabular}


ANEXO I - Dados fitossociológicos da área manejada (A12), sem as espécies introduzidas, municípios de Ituberá, Bahia, Brasil.

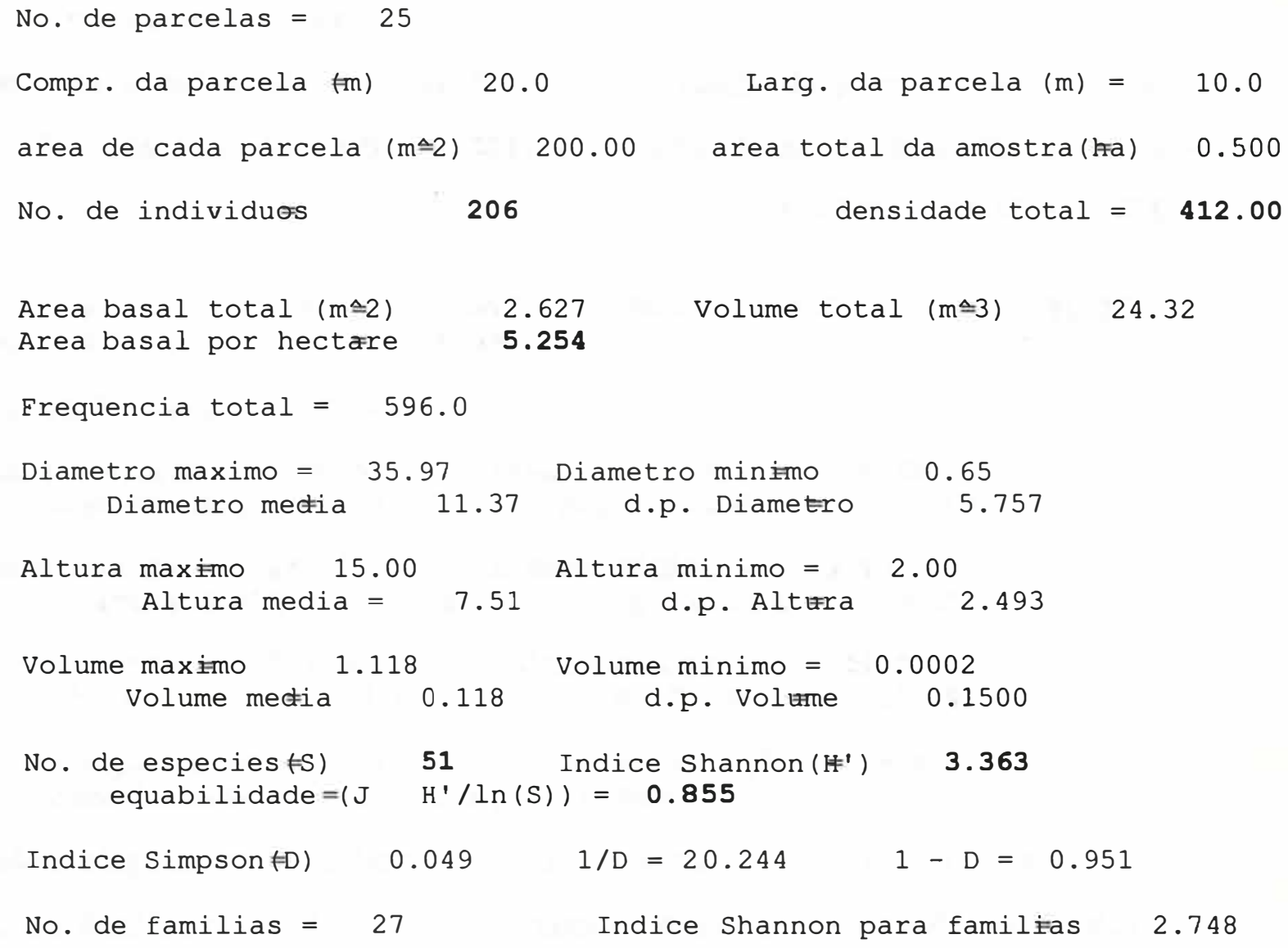

\begin{tabular}{|c|c|c|c|c|c|c|}
\hline especie & No. Ind & No. Amo & Dens. Re & Dom.Rel & Ereq.Re & IVI \\
\hline Inga thibaudiana........... & 30 & 14 & 14.56 & 18.03 & 9.40 & 41.99 \\
\hline Senna multijuga........... & 18 & 10 & 8.74 & 18.33 & 6.71 & 33.78 \\
\hline Tapirira guianensis......... & 12 & 8 & 5.83 & 10.76 & 5.37 & 21.95 \\
\hline Nectandra leucantha........ & 15 & 10 & 7.28 & 7.10 & 6.71 & 21.09 \\
\hline Aegyphyla selowiana......... & 7 & 7 & 3.40 & 6.17 & 4.70 & 14.27 \\
\hline Himatanthus sucuuba......... & 12 & 9 & 5.83 & 1.23 & 6.04 & 13.09 \\
\hline 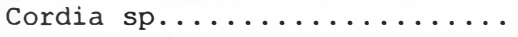 & 9 & 6 & 4.37 & 3.94 & 4.03 & 12.34 \\
\hline Inga blanchetaiana.......... & 11 & 5 & 5.34 & 1.47 & 3.36 & 10.17 \\
\hline Cestrum laevigatum......... & 8 & 6 & 3.88 & 1.21 & 4.03 & 9.12 \\
\hline Didymopanax morototoni....... & 3 & 3 & 1.46 & 4.56 & 2.01 & 8.03 \\
\hline Psychotria mapourioides...... & 6 & 5 & 2.91 & 1.62 & 3.36 & 7.89 \\
\hline Tabernaemontana laeta....... & 5 & 4 & 2.43 & 1.82 & 2.68 & 6.94 \\
\hline Nectandra lanceolata........ & 4 & 3 & 1.94 & 2.65 & 2.01 & 6.61 \\
\hline Mabea fistulifera........... & 5 & 3 & 2.43 & 1.77 & 2.01 & 6.21 \\
\hline Licaria guianensis.......... & 3 & 3 & 1.46 & 1.64 & 2.01 & 5.11 \\
\hline 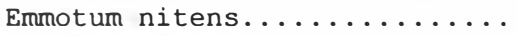 & 3 & 3 & 1.46 & 1.49 & 2.01 & 4.96 \\
\hline Pouteria bangii............ & 3 & 2 & 1.46 & 1.80 & 1.34 & 4.60 \\
\hline Carpotroche brasiliensis..... & 4 & 3 & 1.94 & 0.46 & 2.01 & 4.42 \\
\hline Symphonia globulifera........ & 3 & 3 & 1.46 & 0.86 & 2.01 & 4.33 \\
\hline 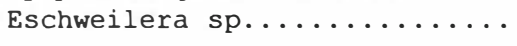 & 3 & 3 & 1.46 & 0.30 & 2.01 & 3.77 \\
\hline 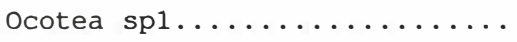 & 3 & 2 & 1.46 & 0.83 & 1.34 & 3.63 \\
\hline
\end{tabular}




\begin{tabular}{|c|c|c|c|c|c|c|}
\hline Guatteria odontopetala... & 3 & 2 & 1.46 & 0.76 & 1.34 & 3.56 \\
\hline Guatteria australis......... & 2 & 2 & 0.97 & 1.05 & 1.34 & 3.37 \\
\hline Eschweilera tetrapetala...... & 2 & 2 & 0.97 & 0.54 & 1.34 & 2.85 \\
\hline Cedrela aff. huberi......... & 1 & 1 & 0.49 & 1.68 & 0.67 & 2.84 \\
\hline Alseis floribunda............ & 2 & 2 & 0.97 & 0.46 & 1.34 & 2.77 \\
\hline Casearia sp.l............ & 2 & 2 & 0.97 & 0.43 & 1.34 & 2.75 \\
\hline 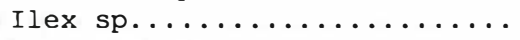 & 2 & 2 & 0.97 & 0.29 & 1.34 & 2.61 \\
\hline Cordia magnolioefolia......... & 2 & 2 & 0.97 & 0.16 & 1.34 & 2.47 \\
\hline Joannesia princeps........... & 2 & 1 & 0.97 & 0.68 & 0.67 & 2.33 \\
\hline indet $.2 \ldots \ldots \ldots \ldots$ & 1 & 1 & 0.49 & 1.15 & 0.67 & 2.30 \\
\hline 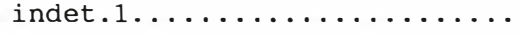 & 1 & 1 & 0.49 & 0.83 & 0.67 & 1.98 \\
\hline Necantra grandiflora.......... & 1 & 1 & 0.49 & 0.57 & 0.67 & 1.72 \\
\hline Pouteria guianensis.......... & 1 & 1 & 0.49 & 0.44 & 0.67 & 1.60 \\
\hline Gomidesia langsdorfii........ & 1 & 1 & 0.49 & 0.37 & 0.67 & 1.52 \\
\hline Sloanea obtusifolia........... & 1 & 1 & 0.49 & 0.36 & 0.67 & 1.52 \\
\hline Matayba juglandifolia........ & 1 & 1 & 0.49 & 0.27 & 0.67 & 1.43 \\
\hline Persea aerata.............. & 1 & 1 & 0.49 & 0.26 & 0.67 & 1.42 \\
\hline Cordia $\operatorname{sp} 2 \ldots \ldots \ldots \ldots \ldots \ldots$ & 1 & 1 & 0.49 & 0.26 & 0.67 & 1.42 \\
\hline 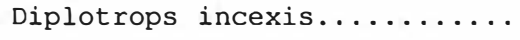 & 1 & 1 & 0.49 & 0.18 & 0.67 & 1.33 \\
\hline Lauraceae $2 \ldots \ldots \ldots \ldots \ldots \ldots$ & 1 & 1 & 0.49 & 0.14 & 0.67 & 1.29 \\
\hline Pera glabrata.............. & 1 & 1 & 0.49 & 0.14 & 0.67 & 1.29 \\
\hline Lecythis lurida............. & 1 & 1 & 0.49 & 0.14 & 0.67 & 1.29 \\
\hline Eugenia rideliana............ & 1 & 1 & 0.49 & 0.13 & 0.67 & 1.28 \\
\hline Eschweilera ovata........... & 1 & 1 & 0.49 & 0.12 & 0.67 & 1.27 \\
\hline Siparuna guianensis.......... & 1 & 1 & 0.49 & 0.12 & 0.67 & 1.27 \\
\hline Lauraceae $1 \ldots \ldots \ldots \ldots \ldots$ & 1 & 1 & 0.49 & 0.10 & 0.67 & 1.26 \\
\hline Pera ferruginea............ & 1 & 1 & 0.49 & 0.10 & 0.67 & 1.25 \\
\hline Courrapoa microcarpa......... & 1 & 1 & 0.49 & 0.09 & 0.67 & 1.25 \\
\hline Rubiaceae $1 \ldots \ldots \ldots \ldots \ldots$ & 1 & 1 & 0.49 & 0.08 & 0.67 & 1.23 \\
\hline Licania tomentosa. & 1 & 1 & 0.49 & 0.08 & 0.67 & 1.23 \\
\hline
\end{tabular}

\begin{tabular}{|c|c|c|c|c|}
\hline especie & IVC & req. Ab & Dens. Ab & Med. \\
\hline Inga thibaudiana............ & 32.59 & 56.00 & 60.0 & 0.0158 \\
\hline Senna multijuga............ & 27.07 & 40.00 & 36.0 & 0.0268 \\
\hline Tapirira guianensis........... & 16.58 & 32.00 & 24.0 & 0.0236 \\
\hline Nectandra leucantha.......... & 14.38 & 40.00 & 30.0 & 0.0124 \\
\hline Aegyphyla selowiana......... & 9.57 & 8.00 & .0 & 0.0232 \\
\hline Himatanthus sucuuba.......... & 7.05 & 36.00 & 24.0 & 027 \\
\hline Cordia sp. $\ldots \ldots \ldots \ldots \ldots \ldots$ & 8.31 & 24.00 & 18.0 & 0.0115 \\
\hline 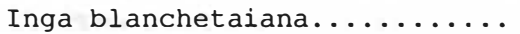 & 6.81 & 20.00 & 22.0 & 035 \\
\hline Cestrum laevigatum.......... & 5.09 & 24.00 & 16.0 & 0.0040 \\
\hline Didymopanax morototoni....... & 6.02 & 12.00 & 6.0 & 0.0400 \\
\hline Psychotria mapourioides........ & 4.53 & & 12.0 & \\
\hline naemontana laeta......... & 4.25 & 16.00 & 10.0 & 0.0096 \\
\hline Nectandra lanceolata......... & 4.60 & 12.00 & 8.0 & .0174 \\
\hline Mabea fistulifera............ & 4.20 & 12.00 & 10.0 & 0.0093 \\
\hline Licaria guianensis.......... & 3.09 & 12.00 & 6.0 & 0.0143 \\
\hline nmotum nitens............ & 2.94 & 12.00 & 6.0 & 0.0130 \\
\hline teria bangii........... & 3.26 & 8.00 & 6.0 & 0.0158 \\
\hline otroche brasiliensis...... & 2.40 & 12.00 & 8.0 & 0.0030 \\
\hline Symphonia globulifera........ & 2.31 & 12.00 & 6.0 & 0.0075 \\
\hline 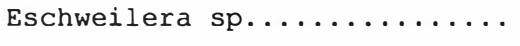 & 1.76 & 12.00 & 6.0 & 0.0026 \\
\hline Ocotea $\operatorname{spl} \ldots \ldots \ldots \ldots \ldots \ldots \ldots$ & 2.29 & 8.00 & 6.0 & 0.0073 \\
\hline Guatteria odontopetala....... & 2.22 & 8.00 & 6.0 & 0.0067 \\
\hline Guatteria australis........... & 2.02 & 8.00 & 4.0 & 0.0138 \\
\hline etala...... & 1.51 & 8.00 & 4.0 & 0.0071 \\
\hline edrela aff. huberi......... & 2.17 & 4.00 & 2.0 & 0.0442 \\
\hline lseis floribunda............. & 1.43 & 8.00 & 4.0 & 0.0060 \\
\hline asearia sp.1........... & 1.40 & 8.00 & 4.0 & 0.0057 \\
\hline Ilex sp....... & 1.27 & 8.00 & 4.0 & 0.0039 \\
\hline
\end{tabular}




\begin{tabular}{|c|c|c|c|c|}
\hline Cordia magnolioefol & 1.13 & 8.00 & 4.0 & 0.0021 \\
\hline Joannesia princeps........... & 1.66 & 4.00 & 4.0 & 0.0090 \\
\hline indet. $2 \ldots$. & 1.63 & 4.00 & 2.0 & 0.0301 \\
\hline 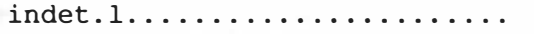 & 1.31 & 4.00 & 2.0 & 0.0217 \\
\hline Nectandra grandiflora......... & 1.05 & 4.00 & 2.0 & 0.0149 \\
\hline Pouteria guianensis........... & 0.93 & 4.00 & 2.0 & 0.0116 \\
\hline Gomidesia langsdorfii........ & 0.85 & 4.00 & 2.0 & 0.0096 \\
\hline Sloanea obtusifolia.......... & 0.85 & 4.00 & 2.0 & 0.0095 \\
\hline Matayba juglandifolia........ & 0.76 & 4.00 & 2.0 & 0.0072 \\
\hline 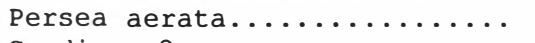 & 0.75 & 4.00 & 2.0 & 0.0069 \\
\hline Cordia $\operatorname{sp} 2 \ldots \ldots \ldots \ldots \ldots \ldots$ & 0.75 & 4.00 & 2.0 & 0.0068 \\
\hline Diplotrops incexis.......... & 0.66 & 4.00 & 2.0 & 0.0047 \\
\hline Lauraceae $2 \ldots \ldots \ldots \ldots \ldots \ldots$ & 0.62 & 4.00 & 2.0 & 0.0036 \\
\hline Pera glabrata.............. & 0.62 & 4.00 & 2.0 & 0.0036 \\
\hline Lecythis lurida............... & 0.62 & 4.00 & 2.0 & 0.0036 \\
\hline Eugenia rideliana............ & 0.61 & 4.00 & 2.0 & 0.0033 \\
\hline Eschweilera ovata.......... & 0.60 & 4.00 & 2.0 & 0.0030 \\
\hline Siparuna guianensis......... & 0.60 & 4.00 & 2.0 & 0.0030 \\
\hline Lauraceae $1 \ldots \ldots \ldots \ldots \ldots$ & 0.59 & 4.00 & 2.0 & 0.0027 \\
\hline Pera ferruginea............ & 0.58 & 4.00 & 2.0 & 0.0026 \\
\hline Coussapoa microcarpa......... & 0.58 & 4.00 & 2.0 & 0.0024 \\
\hline Rubiaceae $1 \ldots \ldots \ldots \ldots \ldots$ & 0.56 & 4.00 & 2.0 & 0.0020 \\
\hline Licania tomentosa........... & 0.56 & 4.00 & 2.0 & 0.0020 \\
\hline
\end{tabular}

\begin{tabular}{|c|c|c|c|c|c|c|c|}
\hline familia & No. Ind & No.Spp & \& Spp & Dens.Ab & Dom.Med. & Freq.Ab & Dens. Re \\
\hline Mimosaceae........ & 41 & 2 & 3.92 & 82.0 & 0.0125 & 72.00 & 19.90 \\
\hline Lauraceae.......... & 29 & 8 & 15.69 & 58.0 & 0.0120 & 60.00 & 14.08 \\
\hline Caesalpiniaceae.... & 18 & 1 & 1.96 & 36.0 & 0.0268 & 40.00 & 8.74 \\
\hline Anacardiaceae ....... & 12 & 1 & 1.96 & 24.0 & 0.0236 & 32.00 & 5.83 \\
\hline Aросуnасеае........ & 17 & 2 & 3.92 & 34.0 & 0.0047 & 52.00 & 8.25 \\
\hline Boraginaceae....... & 12 & 3 & 5.88 & 24.0 & 0.0096 & 28.00 & 5.83 \\
\hline Verbenaceae........ & 7 & 1 & 1.96 & 14.0 & 0.0232 & 28.00 & 3.40 \\
\hline Rubiaceae......... & 9 & 3 & 5.88 & 18.0 & 0.0063 & 28.00 & 4.37 \\
\hline Euphorbiaceae...... & 9 & 4 & 7.84 & 18.0 & 0.0079 & 20.00 & 4.37 \\
\hline Lecythidaceae...... & 7 & 4 & 7.84 & 14.0 & 0.0041 & 28.00 & 3.40 \\
\hline Solanaceae......... & 8 & 1 & 1.96 & 16.0 & 0.0040 & 24.00 & 3.88 \\
\hline Araliaceae......... & 3 & 1 & 1.96 & 6.0 & 0.0400 & 12.00 & 1.46 \\
\hline Flacourtiaceae..... & 6 & 2 & 3.92 & 12.0 & 0.0039 & 20.00 & 2.91 \\
\hline Annonaceae......... & 5 & 2 & 3.92 & 10.0 & 0.0095 & 16.00 & 2.43 \\
\hline Sapotaceae........ & 4 & 2 & 3.92 & 8.0 & 0.0147 & 8.00 & 1.94 \\
\hline Icacinaceae........ & 3 & 1 & 1.96 & 6.0 & 0.0130 & 12.00 & 1.46 \\
\hline Clusiaceae......... & 3 & 1 & 1.96 & 6.0 & 0.0075 & 12.00 & 1.46 \\
\hline indeterminada....... & 2 & 2 & 3.92 & 4.0 & 0.0259 & 8.00 & 0.97 \\
\hline Myrtaceae......... & 2 & 2 & 3.92 & 4.0 & 0.0065 & 8.00 & 0.97 \\
\hline Meliaceae......... & 1 & 1 & 1.96 & 2.0 & 0.0442 & 4.00 & 0.49 \\
\hline Aquifoliaceae...... & 2 & 1 & 1.96 & 4.0 & 0.0039 & 8.00 & 0.97 \\
\hline Elaeocarpaceae...... & 1 & 1 & 1.96 & 2.0 & 0.0095 & 4.00 & 0.49 \\
\hline Sapindaceae........ & 1 & 1 & 1.96 & 2.0 & 0.0072 & 4.00 & 0.49 \\
\hline Fabaceae.......... & 1 & 1 & 1.96 & 2.0 & 0.0047 & 4.00 & 0.49 \\
\hline Monimiaceae....... & 1 & 1 & 1.96 & 2.0 & 0.0030 & 4.00 & 0.49 \\
\hline Moraceae.......... & 1 & 1 & 1.96 & 2.0 & 0.0024 & 4.00 & 0.49 \\
\hline Chrysobalanaceae.... & 1 & 1 & 1.96 & 2.0 & 0.0020 & 4.00 & 0.49 \\
\hline
\end{tabular}

\begin{tabular}{|c|c|c|c|}
\hline familia & Dom.Rel & Ereq. Re & IVI \\
\hline Mimosaceae. & 19.50 & 13.24 & 52.64 \\
\hline Lauraceae.. & 13.29 & 11.03 & 38.4 \\
\hline
\end{tabular}




\begin{tabular}{|c|c|c|c|}
\hline Caesalpiniaceae. . & 18.33 & 7.35 & 34.42 \\
\hline Anacardiaceae....... & 10.76 & 5.88 & 22.47 \\
\hline Apocynaceae........ & 3.05 & 9.56 & 20.86 \\
\hline Boraginaceae........ & 4.36 & 5.15 & 15.33 \\
\hline Verbenaceae......... & 6.17 & 5.15 & 14.72 \\
\hline Rubiaceae.......... & 2.15 & 5.15 & 11.67 \\
\hline Euphorbiaceae...... & 2.69 & 3.68 & 10.74 \\
\hline Lecythidaceae...... & 1.09 & 5.15 & 9.63 \\
\hline Solanaceae.......... & 1.21 & 4.41 & 9.50 \\
\hline Araliaceae......... & 4.56 & 2.21 & 8.23 \\
\hline Elacourtiaceae..... & 0.89 & 3.68 & 7.48 \\
\hline Annonaceae......... & 1.81 & 2.94 & 7.18 \\
\hline Sapotaceae......... & 2.24 & 1.47 & 5.66 \\
\hline Icacinaceae........ & 1.49 & 2.21 & 5.15 \\
\hline Clusiaceae.......... & 0.86 & 2.21 & 4.52 \\
\hline indeterminada....... & 1.97 & 1.47 & 4.41 \\
\hline Myrtaceae......... & 0.49 & 1.47 & 2.93 \\
\hline Meliaceae.......... & 1.68 & 0.74 & 2.90 \\
\hline Aquifoliaceae....... & 0.29 & 1.47 & 2.74 \\
\hline Elaeocarpaceae...... & 0.36 & 0.74 & 1.58 \\
\hline Sapindaceae......... & 0.27 & 0.74 & 1.49 \\
\hline Fabaceae.......... & 0.18 & 0.74 & 1.40 \\
\hline Monimiaceae........ & 0.12 & 0.74 & 1.34 \\
\hline Moraceae........... & 0.09 & 0.74 & 1.31 \\
\hline Chrysobalanaceae.... & 0.08 & 0.74 & 1.30 \\
\hline
\end{tabular}

parcelas No.Ind No.Spp Ar.Bas. Dom.Med. Dens.Ab Alt.Mi Alt.Ma Alt.Me Diam.M

\begin{tabular}{|c|c|c|c|c|c|c|c|c|c|}
\hline $1 \ldots \ldots \ldots$ & 11 & 7 & 0.1781 & 0.0162 & 550.0 & 6.0 & 12.0 & 9.5 & 6.5 \\
\hline $2 \ldots \ldots$ & 6 & 5 & 0.1076 & 0.0179 & 300.0 & 8.0 & 15.0 & 10.5 & 11.0 \\
\hline $3 \ldots \ldots \ldots$ & 11 & 9 & 0.1764 & 0.0160 & 550.0 & 5.5 & 14.0 & 10.6 & 0.7 \\
\hline $4 \ldots \ldots \ldots$ & 11 & 7 & 0.1700 & 0.0155 & 550.0 & 5.0 & 12.5 & 8.4 & 7.0 \\
\hline $5 \ldots \ldots \ldots$ & 9 & 7 & 0.1283 & 0.0143 & 450.0 & 4.0 & 11.0 & 7.7 & 5.6 \\
\hline $6 \ldots \ldots \ldots$ & 11 & 9 & 0.1058 & 0.0096 & 550.0 & 3.0 & 10.0 & 6.6 & 5.4 \\
\hline $7 \ldots \ldots \ldots$ & 5 & 5 & 0.0465 & 0.0093 & 250.0 & 4.0 & 11.0 & 6.8 & 6.5 \\
\hline $8 \ldots \ldots \ldots$ & 9 & 7 & 0.0879 & 0.0098 & 450.0 & 4.0 & 12.0 & 6.8 & 0.7 \\
\hline $9 \ldots \ldots \ldots$ & 4 & 3 & 0.1028 & 0.0257 & 200.0 & 5.5 & 11.0 & 8.3 & 5.4 \\
\hline $10 \ldots \ldots$ & 10 & 6 & 0.1036 & 0.0104 & 500.0 & 4.0 & 13.0 & 7.6 & 5.3 \\
\hline $11 \ldots \ldots$ & 8 & 6 & 0.1077 & 0.0135 & 400.0 & 4.5 & 10.0 & 6.9 & 7.0 \\
\hline $12 \ldots \ldots$ & 10 & ó & 0.1428 & 0.0143 & 500.0 & 6.0 & 10.5 & 7.6 & 7.5 \\
\hline $13 \ldots \ldots$ & 12 & 7 & 0.0926 & 0.0077 & 600.0 & 3.5 & 9.5 & 5.9 & 5.1 \\
\hline $14 \ldots \ldots$ & 8 & 7 & 0.0499 & 0.0062 & 400.0 & 4.0 & 9.0 & 6.1 & 5.0 \\
\hline $15 \ldots \ldots$ & 10 & 6 & 0.1305 & 0.0130 & 500.0 & 6.0 & 11.5 & 8.4 & 5.9 \\
\hline $16 \ldots \ldots$ & 19 & 12 & 0.2271 & 0.0120 & 950.0 & 5.0 & 11.5 & 7.7 & 5.1 \\
\hline $17 \ldots \ldots$ & 11 & 9 & 0.2097 & 0.0191 & 550.0 & 3.0 & 11.0 & 7.2 & 5.3 \\
\hline $18 \ldots \ldots \ldots$ & 6 & 5 & 0.0726 & 0.0121 & 300.0 & 2.0 & 8.0 & 5.3 & 5.6 \\
\hline $172 \ldots \ldots$ & 11 & 7 & 0.1349 & 0.0123 & 550.0 & 5.0 & 9.0 & 7.2 & 5.1 \\
\hline $20 \ldots \ldots$ & 5 & 5 & 0.0408 & 0.0082 & 250.0 & 4.0 & 7.0 & 5.0 & 5.7 \\
\hline $21 \ldots \ldots$ & 6 & 4 & 0.0376 & 0.0063 & 300.0 & 5.0 & 7.0 & 5.5 & 5.7 \\
\hline $22 \ldots \ldots$ & 3 & 3 & 0.0462 & 0.0154 & 150.0 & 5.0 & 10.0 & 7.3 & 5.7 \\
\hline $23 \ldots \ldots$ & 6 & 5 & 0.0799 & 0.0133 & 300.0 & 5.0 & 11.0 & 7.3 & 4.9 \\
\hline $24 \ldots \ldots$ & 0 & 0 & 0.0000 & 0.0000 & 0.0 & 0.0 & 0.0 & 0.0 & 0.0 \\
\hline $25 \ldots \ldots \ldots$ & 4 & 2 & 0.0479 & 0.0120 & 200.0 & 5.0 & 10.0 & 7.8 & 6.4 \\
\hline
\end{tabular}

parcelas Diam.M

$1 \ldots \ldots .20 .9$

$2 \ldots \ldots \ldots \quad 17.8$

$3 \ldots \ldots \ldots \quad 21.2$

$4 \ldots \ldots \ldots 27.7$

$5 \ldots \ldots \ldots 23.7$ 


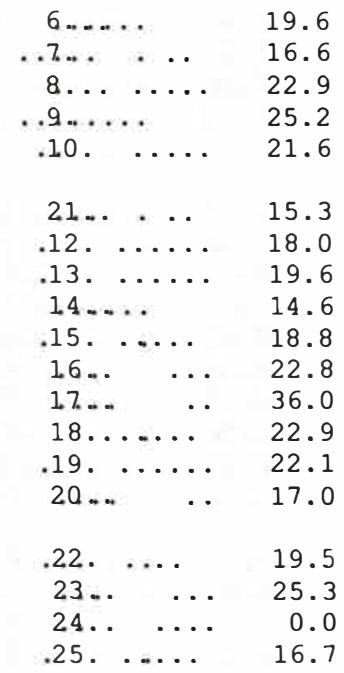

ANEXO J - Dados fitossociológicos da área manejada (A12), com as espécies introduzidas, município de Ituberá, Bahia, Brasil.

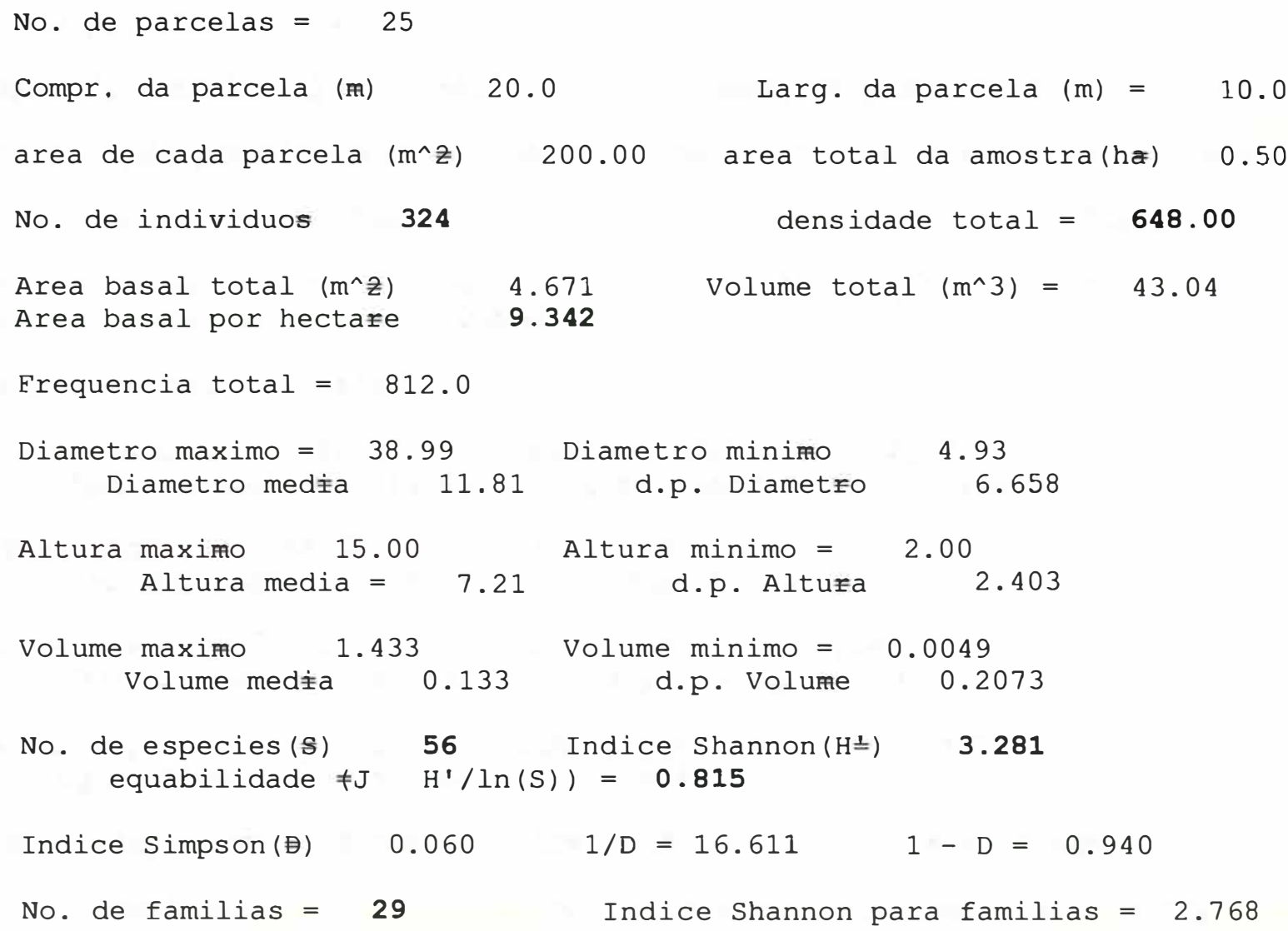




\begin{tabular}{|c|c|c|c|c|c|c|}
\hline especie & No. Ind & No. Amo & Dens. Re & Dom.Rel $\mathrm{E}$ & Ereq. Re & IVI \\
\hline rtocarpus heterophyllus...... & 43 & 17 & 13.27 & 20.68 & 8.37 & 42.33 \\
\hline Theobroma bicolor........... & 47 & 20 & 14.51 & 9.53 & 9.85 & 33.89 \\
\hline Inga thibaudiana........... & 30 & 14 & 9.26 & 10.21 & 6.90 & 26.37 \\
\hline Erythrina poeppigiana........ & 13 & 11 & 4.01 & 12.29 & 5.42 & 21.73 \\
\hline Senna multijuga............ & 18 & 10 & 5.56 & 10.31 & 4.93 & 20.79 \\
\hline Tapirira guianensis........... & 12 & 8 & 3.70 & 6.05 & 3.94 & 13.70 \\
\hline Nectandra leucantha.......... & 15 & 10 & 4.63 & 3.99 & 4.93 & 13.55 \\
\hline Aegyphyla selowiana......... & 7 & 7 & 2.16 & 3.47 & 3.45 & 9.08 \\
\hline Himatanthus sucuuba.......... & 12 & 9 & 3.70 & 0.69 & 4.43 & 8.83 \\
\hline Cordia sp................. & 9 & 6 & 2.78 & 2.22 & 2.96 & 7.95 \\
\hline Inga blanchetaiana.......... & 11 & 5 & 3.40 & 0.83 & 2.46 & 6.69 \\
\hline Cestrum laevigatum........... & 8 & 6 & 2.47 & 0.68 & 2.96 & 6.10 \\
\hline Psychotria mapourioides....... & 6 & 5 & 1.85 & 0.91 & 2.46 & 5.23 \\
\hline Persea americana............ & 8 & 4 & 2.47 & 0.68 & 1.97 & 5.12 \\
\hline Didymopanax morototoni....... & 3 & 3 & 0.93 & 2.57 & 1.48 & 4.97 \\
\hline Tabernaemontana laeta........ & 5 & 4 & 1.54 & 1.03 & 1.97 & 4.54 \\
\hline Nectandra lanceolata......... & 4 & 3 & 1.23 & 1.49 & 1.48 & 4.20 \\
\hline Mabea fistulifera........... & 5 & 3 & 1.54 & 1.00 & 1.48 & 4.02 \\
\hline Guatteria australis......... & 3 & 3 & 0.93 & 1.06 & 1.48 & 3.46 \\
\hline Licaria guianensis.......... & 3 & 3 & 0.93 & 0.92 & 1.48 & 3.32 \\
\hline Emmotum nitens.. & 3 & 3 & 0.93 & 0.84 & 1.48 & 3.24 \\
\hline fairchildiana......... & 6 & 2 & 1.85 & 0.38 & 0.99 & 3.21 \\
\hline Carpotroche brasiliensis...... & 4 & 3 & 1.23 & 0.26 & 1.48 & 2.97 \\
\hline a bangii............. & 3 & 2 & 0.93 & 1.01 & 0.99 & 2.92 \\
\hline Symphonia globulifera........ & 3 & 3 & 0.93 & 0.48 & 1.48 & 2.89 \\
\hline 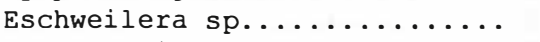 & 3 & 3 & 0.93 & 0.24 & 1.48 & 2.64 \\
\hline Ocotea $\operatorname{sp} 1 \ldots \ldots \ldots \ldots \ldots \ldots$ & 3 & 2 & 0.93 & 0.47 & 0.99 & 2.38 \\
\hline Guatteria odontopetala....... & 3 & 2 & 0.93 & 0.43 & 0.99 & 2.34 \\
\hline Eschweilera tetrapetala...... & 2 & 2 & 0.62 & 0.30 & 0.99 & 1.90 \\
\hline Alseis floribunda............ & 2 & 2 & 0.62 & 0.26 & 0.99 & 1.86 \\
\hline a sp. & 2 & 2 & & 0.24 & 0.99 & 1.85 \\
\hline Cedrela aff. huberi......... & 1 & 1 & 0.31 & 0.95 & 0.49 & 1.75 \\
\hline Cordia magnolioefolia........ & 2 & 2 & 0.62 & 0.09 & 0.99 & 1.69 \\
\hline Joannesia princeps.......... & 2 & 1 & 0.62 & 0.39 & 0.49 & 1.50 \\
\hline indet. $2 \ldots \ldots \ldots \ldots \ldots \ldots \ldots$ & 1 & 1 & .31 & .64 & 0.49 & 1.45 \\
\hline olia........... & 2 & 1 & .62 & .30 & 0.49 & 1.41 \\
\hline Necantra grandiflora......... & 1 & 1 & 0.31 & 0.32 & 0.49 & 1.12 \\
\hline asis......... & 1 & 1 & 0.31 & 0.25 & 0.49 & 1.05 \\
\hline Gomidesia langsdorfii........ & 1 & 1 & 0.31 & 0.21 & 0.49 & 1.01 \\
\hline Matayba juglandifolia........ & 1 & 1 & 0.31 & 0.15 & 0.49 & 0.95 \\
\hline$\ldots \ldots \ldots \ldots \ldots$ & 1 & 1 & & .15 & & .95 \\
\hline$\ldots \ldots \ldots \ldots \ldots$ & 1 & 1 & .31 & .15 & 9 & 0.95 \\
\hline Diplotrops incexis.......... & 1 & 1 & 0.31 & 0.10 & .49 & 0.90 \\
\hline 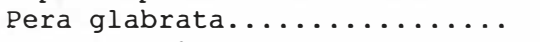 & 1 & 1 & 0.31 & 0.08 & $0.4 \mathrm{~s}-0.00$ & 0.88 \\
\hline Lauraceae $2 \ldots \ldots \ldots \ldots \ldots$ & 1 & 1 & 0.31 & 0.08 & 0.49 & 0.88 \\
\hline Lecythis lurida............. & 1 & 1 & 0.31 & 0.08 & 0.49 & 0.88 \\
\hline Eugenia rideliana........... & 1 & 1 & 0.31 & 0.07 & 0.49 & 0.87 \\
\hline$p \ldots \ldots \ldots \ldots \ldots \ldots$ & 1 & 1 & 0.31 & 0.07 & 0.49 & 0.87 \\
\hline Siparuna guianensis......... & 1 & 1 & 0.31 & 0.06 & 0.49 & 0.87 \\
\hline Eschweilera ovata........... & 1 & 1 & 0.31 & 0.06 & 0.49 & 0.87 \\
\hline Lauraceae $1 \ldots \ldots \ldots \ldots \ldots \ldots$ & 1 & 1 & 0.31 & 0.06 & 0.49 & 0.86 \\
\hline Citrus limettioides.......... & 1 & 1 & 0.31 & 0.06 & 0.49 & 0.86 \\
\hline Pera ferruginea............. & 1 & 1 & 0.31 & 0.06 & 0.49 & 0.86 \\
\hline ourrapoa microcarpa......... & 1 & 1 & 0.31 & 0.05 & 0.49 & 0.85 \\
\hline Rubiaceae $1 \ldots \ldots \ldots \ldots \ldots$ & 1 & 1 & 0.31 & 0.04 & 0.49 & 0.84 \\
\hline Licania tomentosa............ & 1 & 1 & 0.31 & 0.04 & 0.49 & 0.84 \\
\hline
\end{tabular}




\begin{tabular}{|c|c|c|c|c|}
\hline especie & IVC E & q. $A b D$ & Dens.Ab & Dom. Med. \\
\hline Artocarpus heterophyllus..... & 33.96 & 68.00 & 86.0 & 0.0225 \\
\hline Theobroma bicolor............ & 24.03 & 80.00 & 94.0 & 0.0095 \\
\hline 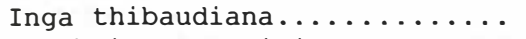 & 19.47 & 56.00 & 60.0 & 0.0159 \\
\hline Erythrina poeppigiana........ & 16.31 & 44.00 & 26.0 & 0.0442 \\
\hline 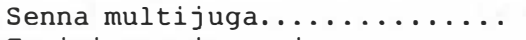 & 15.87 & 40.00 & 36.0 & 0.0268 \\
\hline Tapirira guianensis.......... & 9.75 & 32.00 & 24.0 & 0.0236 \\
\hline Nectandra leucantha.......... & 8.62 & 40.00 & 30.0 & 0.0124 \\
\hline Aegyphyla selowiana......... & 5.63 & 28.00 & 14.0 & 0.0232 \\
\hline Himatanthus sucuuba.......... & 4.39 & 36.00 & 24.0 & 0.0027 \\
\hline Cordia sp................... & 4.99 & 24.00 & 18.0 & 0.0115 \\
\hline Inga blanchetaiana........... & 4.22 & 20.00 & 22.0 & 0.0035 \\
\hline Cestrum laevigatum.......... & 3.15 & 24.00 & 16.0 & 0.0040 \\
\hline Psychotria mapourioides...... & 2.76 & 20.00 & 12.0 & 0.0071 \\
\hline Persea americana............. & 3.15 & 16.00 & 16.0 & 0.0040 \\
\hline Didymopanax morototoni....... & 3.49 & 12.00 & 6.0 & 400 \\
\hline Tabernaemontana laet & 2.57 & 16.00 & 10.0 & 0.0096 \\
\hline Nectandra lanceolata......... & 2.73 & 12.00 & 8.0 & 0.0174 \\
\hline Mabea fistulifera............. & 2.54 & 00 & 10. & 0.0093 \\
\hline Guatteria australis.......... & 1.98 & 12.00 & 6.0 & 0.0164 \\
\hline Licaria guianensis........... & 1.85 & 12.00 & 6.0 & 0.0143 \\
\hline m nitens.... & 1.76 & 12.00 & 6.0 & 0.0130 \\
\hline Clitora fairchildiana........ & 2.23 & 8.00 & 12.0 & .0029 \\
\hline troche brasiliensis..... & 1.49 & 12.00 & 8.0 & .0030 \\
\hline eria bangii............ & 1.94 & 8.00 & 6.0 & .0158 \\
\hline nonia globulifera........ & 1.41 & 12.00 & 6.0 & .0075 \\
\hline 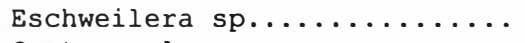 & 1.17 & 12.00 & 6.0 & .0037 \\
\hline ea spl................ & 1.39 & 8.00 & 6.0 & 073 \\
\hline ria odontopet & 1.35 & 8.00 & 6.0 & .0067 \\
\hline Eschweilera tetrapetala...... & 0.92 & 8.00 & 4.0 & .0071 \\
\hline 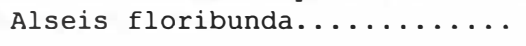 & 0.87 & 8.00 & 4.0 & 0.0060 \\
\hline$\ldots \ldots \ldots$ & 0.86 & 8.00 & 4.0 & 0.0057 \\
\hline a aff. huber & 1.25 & 4.00 & 2.0 & .0442 \\
\hline a magnolioefolia......... & 0.71 & 8.00 & 4.0 & .0021 \\
\hline sia princeps........... & 1.00 & 4.00 & 4.0 & .0090 \\
\hline$\ldots \ldots \ldots \ldots \ldots \ldots \ldots$ & 0.9 & 4.00 & 2.0 & .0301 \\
\hline Sloanea obtusifolia.......... & 0.91 & 4.00 & 4.0 & 0.0069 \\
\hline Necantra grandiflora......... & 0.63 & 4.00 & 2.0 & 0.0149 \\
\hline Pouteria guianensis.......... & 0.56 & 4.00 & 2.0 & 0.0116 \\
\hline Gomidesia langsdorfii........ & 0.51 & 4.00 & 2.0 & .0096 \\
\hline Matayba juglandifolia........ & 0.46 & 4.00 & 2.0 & 0.0072 \\
\hline & & 4.00 & 2.0 & .0069 \\
\hline Cordia sp2............... & 0.4 & 4.00 & 2.0 & 0.0068 \\
\hline Diplotrops incexis.......... & 0.41 & 4.00 & 2.0 & 0.0047 \\
\hline Pera glabrata.............. & 0.39 & 4.00 & 2.0 & 0.0036 \\
\hline Lauraceae $2 \ldots \ldots \ldots \ldots \ldots \ldots$ & 0.39 & .00 & 2.0 & 0.0036 \\
\hline this lurida............. & 0.3 & 4.00 & 2.0 & 0.0036 \\
\hline enia rideliana............ & 0.3 & 4.00 & 2.0 & 0.0033 \\
\hline 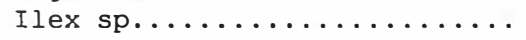 & 0.38 & 4.00 & 2.0 & 0.0033 \\
\hline Siparuna guianensis......... & 0.37 & 4.00 & 2.0 & 0.0030 \\
\hline Eschweilera ovata............ & 0.37 & 4.00 & 2.0 & 0.0030 \\
\hline & & 4.0 & & 0.0027 \\
\hline us limettioides........... & 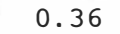 & 4.00 & 2 . & 0.0026 \\
\hline Pera ferruginea............ & 0.36 & 4.00 & 2.0 & 0.0026 \\
\hline Coussapoa microcarpa.......... & 0.36 & 4.00 & 2.0 & 0.0024 \\
\hline Rubiaceae $1 \ldots \ldots \ldots \ldots \ldots$ & 0.35 & 4.00 & 2.0 & 0.0020 \\
\hline Licania tomentosa. & 0.35 & 4.00 & 2.0 & 0.0020 \\
\hline
\end{tabular}




\begin{tabular}{|c|c|c|c|c|c|c|c|}
\hline familia & No. Ind & No.Spp & ३spp & Dens. Ab & Dom. Med. & Freq. Ab & Dens. Re \\
\hline Moraceae... & 44 & 2 & 3.57 & 88.0 & 0.0220 & 72.00 & 13.58 \\
\hline Sterculiaceae....... & 47 & 1 & 1.79 & 94.0 & 0.0095 & 80.00 & 14.51 \\
\hline Mimosaceae......... & 41 & 2 & 3.57 & 82.0 & 0.0126 & 72.00 & 12.65 \\
\hline Lauraceae........... & 37 & 9 & 16.07 & 74.0 & 0.0103 & 64.00 & 11.42 \\
\hline Fabaceae.......... & 20 & 3 & 5.36 & 40.0 & 0.0298 & 56.00 & 6.17 \\
\hline Caesalpiniaceae..... & 18 & 1 & 1.79 & 36.0 & 0.0268 & 40.00 & 5.56 \\
\hline Anacardiaceae...... & 12 & 1 & 1.79 & 24.0 & 0.0236 & 32.00 & 3.70 \\
\hline Apocynaceae......... & 17 & 2 & 3.57 & 34.0 & 0.0047 & 52.00 & 5.25 \\
\hline Boraginaceae........ & 12 & 3 & 5.36 & 24.0 & 0.0096 & 28.00 & 3.70 \\
\hline Verbenaceae........ & 7 & 1 & 1.79 & 14.0 & 0.0232 & 28.00 & 2.16 \\
\hline Rubiaceae......... & 9 & 3 & 5.36 & 18.0 & 0.0063 & 28.00 & 2.78 \\
\hline Euphorbiaceae....... & 9 & 4 & 7.14 & 18.0 & 0.0079 & 20.00 & 2.78 \\
\hline Lecythidaceae....... & 7 & 4 & 7.14 & 14.0 & 0.0046 & 28.00 & 2.16 \\
\hline Solanaceae......... & 8 & 1 & 1.79 & 16.0 & 0.0040 & 24.00 & 2.47 \\
\hline Annonaceae ......... & 6 & 2 & 3.57 & 12.0 & 0.0115 & 20.00 & 1.85 \\
\hline Araliaceae......... & 3 & 1 & 1.79 & 6.0 & 0.0400 & 12.00 & 0.93 \\
\hline Flacourtiaceae..... & 6 & 2 & 3.57 & 12.0 & 0.0039 & 20.00 & 1.85 \\
\hline Sapotaceae........ & 4 & 2 & 3.57 & 8.0 & 0.0147 & 8.00 & 1.23 \\
\hline Icacinaceae........ & 3 & 1 & 1.79 & 6.0 & 0.0130 & 12.00 & 0.93 \\
\hline Clusiaceae......... & 3 & 1 & 1.79 & 6.0 & 0.0075 & 12.00 & 0.93 \\
\hline Myrtaceae.......... & 2 & 2 & 3.57 & 4.0 & 0.0065 & 8.00 & 0.62 \\
\hline Meliaceae......... & 1 & 1 & 1.79 & 2.0 & 0.0442 & 4.00 & 0.31 \\
\hline indeterminada....... & 1 & 1 & 1.79 & 2.0 & 0.0301 & 4.00 & 0.31 \\
\hline Elaeocarpaceae...... & 2 & 1 & 1.79 & 4.0 & 0.0069 & 4.00 & 0.62 \\
\hline Sapindaceae........ & 1 & 1 & 1.79 & 2.0 & 0.0072 & 4.00 & 0.31 \\
\hline Aquifoliaceae...... & 1 & 1 & 1.79 & 2.0 & 0.0033 & 4.00 & 0.31 \\
\hline Monimiaceae........ & 1 & 1 & 1.79 & 2.0 & 0.0030 & 4.00 & 0.31 \\
\hline Rutaceae......... & 1 & 1 & 1.79 & 2.0 & 0.0026 & 4.00 & 0.31 \\
\hline Chrysobalanaceae.... & 1 & 1 & 1.79 & 2.0 & 0.0020 & 4.00 & 0.31 \\
\hline
\end{tabular}

\begin{tabular}{|c|c|c|c|}
\hline familia & Dom. Rel & Freq. Re & IVI \\
\hline Moraceae.......... & 20.74 & 9.63 & 43.94 \\
\hline Sterculiaceae...... & 9.53 & 10.70 & 34.73 \\
\hline Mimosaceae........ & 11.04 & 9.63 & 33.32 \\
\hline Lauraceae........... & 8.15 & 8.56 & 28.13 \\
\hline Fabaceae.......... & 12.77 & 7.49 & 26.43 \\
\hline Caesalpiniaceae..... & 10.31 & 5.35 & 21.21 \\
\hline Anacardiaceae....... & 6.05 & 4.28 & 14.03 \\
\hline Apocynaceae......... & 1.72 & 6.95 & 13.91 \\
\hline Boraginaceae........ & 2.45 & 3.74 & 9.90 \\
\hline Verbenaceae........ & 3.47 & 3.74 & 9.37 \\
\hline Rubiaceae.......... & 1.21 & 3.74 & 7.73 \\
\hline Euphorbiaceae...... & 1.51 & 2.67 & 6.97 \\
\hline Lecythidaceae....... & 0.68 & 3.74 & 6.59 \\
\hline Solanaceae.......... & 0.68 & 3.21 & 6.36 \\
\hline Annonaceae......... & 1.48 & 2.67 & 6.01 \\
\hline Araliaceae......... & 2.57 & 1.60 & 5.10 \\
\hline Flacourtiaceae...... & 0.50 & 2.67 & 5.03 \\
\hline Sapotaceae......... & 1.26 & 1.07 & 3.57 \\
\hline Icacinaceae......... & 0.84 & 1.60 & 3.37 \\
\hline Clusiaceae......... & 0.48 & 1.60 & 3.01 \\
\hline Myrtaceae......... & 0.28 & 1.07 & 1.96 \\
\hline Meliaceae......... & 0.95 & 0.53 & 1.79 \\
\hline indeterminada....... & 0.64 & 0.53 & 1.49 \\
\hline Elaeocarpaceae..... & 0.30 & 0.53 & 1.45 \\
\hline Sapindaceae......... & 0.15 & 0.53 & 1.00 \\
\hline Aquifoliaceae....... & 0.07 & 0.53 & 0.92 \\
\hline Monimiaceae......... & 0.06 & 0.53 & 0.91 \\
\hline
\end{tabular}




$\begin{array}{llll}\text { Rutaceae........... } & 0.06 & 0.53 & 0.90 \\ \text { Chrysobalanaceae... } & 0.04 & 0.53 & 0.89\end{array}$

\begin{tabular}{lrrrrrrr}
\multicolumn{2}{c}{-1} \\
parcelas
\end{tabular}

parcelas Diam.M

. $1, \ldots \ldots 20.9$

..2. . . . 24.5

... 3. ... 21.2

$\ldots 4 \ldots \ldots 27.7$

..5. . . . 2 28.2

$\ldots 6, \ldots \ldots \quad 36.6$

$7: \ldots \ldots \quad 24.2$

...8. . . 22.9

$9 \ldots \ldots 25.2$

.. $10, \ldots \ldots 32.6$

$\ldots 11 \ldots \ldots 23.4$

$12, \ldots \ldots \quad 18.0$

$13 \ldots \ldots \ldots \quad 19.6$

. $14 . \ldots 29.6$

$15 \ldots 18.8$

$16 . \ldots \ldots 24.3$

$17, \ldots . \quad 36.0$

.. $18, \ldots \ldots 29.0$

$19, \ldots \ldots \quad 22.1$

.. $20 \ldots \ldots \quad 17.5$

$21, \ldots \ldots \quad 15.3$

$22, \ldots \ldots \quad 19.5$

$23 \ldots \ldots 28.2$

. $24 . \ldots 39.0$

...25. 35.0 
ANEXO K - Correlação cofenética, escores para parcelas e autovetor.

Tipo de coeficiente :Jaccard

I $P 1$

0.1667 । P2

$30.13330 .1538 \quad \mathrm{P} 3$

$\begin{array}{llllll}4 & 0.1667 & 0.2000 & 0.2500 & \text { I } & \text { P4 }\end{array}$

$5 \quad 0.0000 \quad 0.1818 \quad 0.0667 \quad 0.0833 \quad$ I 55

$\begin{array}{llllllll}0.0625 & 0.0714 & 0.2857 & 0.2500 & 0.0667 & \text { I } 6\end{array}$

$0.0000 \quad 0.1000 \quad 0.0000 \quad 0.0000 \quad 0.09090 .0769 \quad$ P7

$\begin{array}{lllllllll}0.0769 & 0.0909 & 0.0714 & 0.0909 & 0.0833 & 0.2500 & 0.2222 \quad \text { P8 }\end{array}$

$\begin{array}{llllllllllll}0.1000 & 0.0000 & 0.0909 & 0.1250 & 0.1111 & 0.0909 & 0.0000 & 0.1250 & \text { P9 }\end{array}$

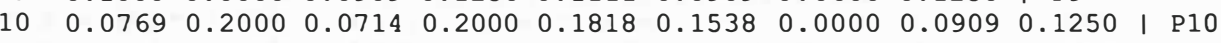

$\begin{array}{lllllllllllll}11 & 0.1667 & 0.5000 & 0.1538 & 0.2000 & 0.1818 & 0.1538 & 0.0000 & 0.0000 & 0.0000 & 0.2000\end{array}$

$12 \quad 0.0000 \quad 0.2000 \quad 0.1538 \quad 0.0909 \quad 0.4444 \quad 0.1538 \quad 0.0000 \quad 0.0909 \quad 0.0000 \quad 0.0909$

$\begin{array}{llllllllllllll}13 & 0.0714 & 0.1818 & 0.0667 & 0.1818 & 0.1667 & 0.1429 & 0.2000 & 0.0833 & 0.0000 & 0.1818\end{array}$

$\begin{array}{lllllllllllll}14 & 0.0000 & 0.0000 & 0.0667 & 0.0833 & 0.0769 & 0.1429 & 0.0909 & 0.0000 & 0.0000 & 0.0833\end{array}$

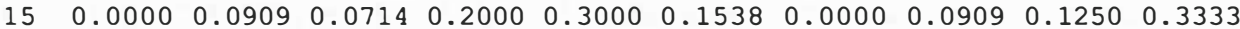

$\begin{array}{lllllllllllll}16 & 0.0526 & 0.0588 & 0.1053 & 0.1250 & 0.1875 & 0.1667 & 0.0625 & 0.0588 & 0.1538 & 0.1250\end{array}$

$\begin{array}{lllllllllllll}17 & 0.0625 & 0.0714 & 0.1250 & 0.1538 & 0.1429 & 0.2000 & 0.0000 & 0.1538 & 0.3333 & 0.2500\end{array}$

$\begin{array}{lllllllllllll}18 & 0.0000 & 0.0000 & 0.0769 & 0.1000 & 0.0909 & 0.2727 & 0.2500 & 0.1000 & 0.1429 & 0.1000\end{array}$

$\begin{array}{lllllllllllll}19 & 0.1538 & 0.1818 & 0.2308 & 0.4444 & 0.0769 & 0.3333 & 0.0000 & 0.1818 & 0.1111 & 0.4444\end{array}$

$\begin{array}{lllllllllllll}20 & 0.0833 & 0.2222 & 0.0769 & 0.2222 & 0.0909 & 0.0769 & 0.0000 & 0.0000 & 0.1429 & 0.3750\end{array}$

$\begin{array}{lllllllllllll}21 & 0.0000 & 0.0000 & 0.0000 & 0.0000 & 0.1000 & 0.1818 & 0.2857 & 0.2500 & 0.1667 & 0.2500\end{array}$

$\begin{array}{llllllllllll}22 & 0.1000 & 0.0000 & 0.0909 & 0.1250 & 0.0000 & 0.3333 & 0.1429 & 0.5000 & 0.2000 & 0.1250\end{array}$

$\begin{array}{llllllllllll}23 & 0.0000 & 0.0000 & 0.0769 & 0.0000 & 0.0909 & 0.0769 & 0.0000 & 0.2222 & 0.1429 & 0.2222\end{array}$

$\begin{array}{lllllllllllll}24 & 0.0000 & 0.0000 & 0.0000 & 0.0000 & 0.0000 & 0.0000 & 0.0000 & 0.0000 & 0.0000 & 0.0000\end{array}$

$\begin{array}{llllllllllllll}25 & 0.0000 & 0.0000 & 0.0000 & 0.0000 & 0.1250 & 0.0000 & 0.0000 & 0.1429 & 0.2500 & 0.1429\end{array}$

$\begin{array}{lllllllllllllll}26 & 0.1053 & 0.1176 & 0.1000 & 0.1176 & 0.0000 & 0.1000 & 0.0000 & 0.1176 & 0.1429 & 0.1176\end{array}$

$\begin{array}{lllllllllllll}27 & 0.0870 & 0.0455 & 0.0000 & 0.0455 & 0.0000 & 0.0400 & 0.0000 & 0.0455 & 0.0000 & 0.0952\end{array}$

$\begin{array}{lllllllllllll}28 & 0.0000 & 0.0000 & 0.0435 & 0.0000 & 0.0476 & 0.0000 & 0.0000 & 0.0000 & 0.0588 & 0.0000\end{array}$

$\begin{array}{llllllllllll}29 & 0.0000 & 0.0000 & 0.0000 & 0.0500 & 0.0000 & 0.0000 & 0.0000 & 0.0000 & 0.0588 & 0.0000\end{array}$

$\begin{array}{llllllllllll}30 & 0.0000 & 0.0000 & 0.0435 & 0.0500 & 0.0476 & 0.0000 & 0.0000 & 0.0000 & 0.0588 & 0.0500\end{array}$

$\begin{array}{llllllllllll}31 & 0.0000 & 0.0000 & 0.0435 & 0.0000 & 0.0476 & 0.0000 & 0.0000 & 0.0000 & 0.0588 & 0.0500\end{array}$

$\begin{array}{lllllllllllll}32 & 0.0357 & 0.0385 & 0.0714 & 0.0800 & 0.0370 & 0.0345 & 0.0000 & 0.0385 & 0.0435 & 0.1250\end{array}$

$\begin{array}{lllllllllllll}33 & 0.0690 & 0.0357 & 0.0323 & 0.0741 & 0.0000 & 0.0323 & 0.0000 & 0.0357 & 0.0000 & 0.0741\end{array}$

$\begin{array}{llllllllllll}34 & 0.0476 & 0.0000 & 0.0455 & 0.0526 & 0.0000 & 0.0455 & 0.0000 & 0.0526 & 0.0000 & 0.0526\end{array}$

$\begin{array}{lllllllllllll}35 & 0.0385 & 0.0417 & 0.0370 & 0.0870 & 0.0000 & 0.0000 & 0.0000 & 0.0000 & 0.0476 & 0.0417\end{array}$ ^ 个
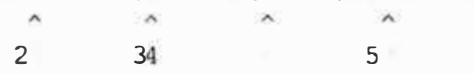

6

$$
7
$$

8

9

10

Jaccard

$11 \mid \mathrm{P} 11$

120.3333 | $\mathrm{P} 12$

$130.18180 .1818 \mid \mathrm{P} 13$

$\begin{array}{llllll}14 & 0.0833 & 0.1818 & 0.1667 & \text { I } & \text { P14 }\end{array}$

$\begin{array}{llllllll}15 & 0.0909 & 0.2000 & 0.1818 & 0.1818 & \text { । } & \text { P15 }\end{array}$

$\begin{array}{lllllllll}16 & 0.1250 & 0.2000 & 0.1176 & 0.1176 & 0.2000 & \text { P } 16\end{array}$

$\begin{array}{llllllllll}17 & 0.0714 & 0.0714 & 0.1429 & 0.0000 & 0.2500 & 0.2353 \quad \mathrm{P} 17\end{array}$

$\begin{array}{lllllllllll}18 & 0.1000 & 0.1000 & 0.2000 & 0.2000 & 0.1000 & 0.1333 & 0.0769 & \text { । } 18\end{array}$

$\begin{array}{llllllllllllll}19 & 0.1818 & 0.0833 & 0.1667 & 0.0000 & 0.1818 & 0.1176 & 0.2308 & 0.0909 & \text { P19 }\end{array}$

$\begin{array}{llllllllllllllll}20 & 0.2222 & 0.1000 & 0.2000 & 0.0909 & 0.1000 & 0.0625 & 0.1667 & 0.0000 & 0.2000 & \text { P } 20\end{array}$

$\begin{array}{lllllllllllll}21 & 0.0000 & 0.0000 & 0.2222 & 0.1000 & 0.2500 & 0.0667 & 0.1818 & 0.5000 & 0.1000 & 0.0000\end{array}$

$\begin{array}{llllllllllll}22 & 0.0000 & 0.0000 & 0.1111 & 0.0000 & 0.1250 & 0.0714 & 0.2000 & 0.1429 & 0.2500 & 0.0000\end{array}$

$\begin{array}{lllllllllllll}23 & 0.0000 & 0.1000 & 0.0000 & 0.0000 & 0.2222 & 0.0625 & 0.1667 & 0.1111 & 0.0909 & 0.0000\end{array}$

$\begin{array}{lllllllllllll}24 & 0.0000 & 0.0000 & 0.0000 & 0.0000 & 0.0000 & 0.0000 & 0.0000 & 0.0000 & 0.0000 & 0.0000\end{array}$

$\begin{array}{llllllllllllll}25 & 0.0000 & 0.0000 & 0.0000 & 0.0000 & 0.1429 & 0.0769 & 0.1000 & 0.1667 & 0.0000 & 0.0000\end{array}$

$\begin{array}{llllllllllllll}26 & 0.1176 & 0.0000 & 0.0526 & 0.0000 & 0.0556 & 0.0417 & 0.1579 & 0.0000 & 0.1765 & 0.1250\end{array}$

$27 \quad 0.0455 \quad 0.0000 \quad 0.04350 .0000 \quad 0.0455 \quad 0.0000 \quad 0.0400 \quad 0.00000 .09090 .0476$

$\begin{array}{lllllllllllll}28 & 0.0000 & 0.0500 & 0.0000 & 0.0000 & 0.0000 & 0.0000 & 0.0435 & 0.0000 & 0.0000 & 0.0526\end{array}$

$\begin{array}{lllllllllllll}29 & 0.0000 & 0.0000 & 0.0000 & 0.0476 & 0.0500 & 0.0000 & 0.0435 & 0.0000 & 0.0000 & 0.0526\end{array}$

$\begin{array}{lllllllllllll}30 & 0.0000 & 0.0500 & 0.0000 & 0.0476 & 0.1053 & 0.0385 & 0.0435 & 0.0526 & 0.0000 & 0.0000\end{array}$

$\begin{array}{lllllllllllll}31 & 0.0000 & 0.0500 & 0.0000 & 0.0000 & 0.0500 & 0.0385 & 0.0435 & 0.0526 & 0.0000 & 0.0000\end{array}$

$\begin{array}{lllllllllllll}32 & 0.0385 & 0.0385 & 0.0370 & 0.0370 & 0.1250 & 0.0313 & 0.0714 & 0.0400 & 0.0769 & 0.0400\end{array}$ 
$\begin{array}{lllllllllll}33 & 0.0357 & 0.0000 & 0.0345 & 0.0345 & 0.0741 & 0.0000 & 0.0323 & 0.0000 & 0.0714 & 0.0370\end{array}$

$\begin{array}{llllllllllll}34 & 0.0000 & 0.0000 & 0.0000 & 0.0500 & 0.1111 & 0.0000 & 0.0455 & 0.0000 & 0.0500 & 0.0000\end{array}$

$\begin{array}{lllllllllll}35 & 0.0417 & 0.0417 & 0.0400 & 0.0400 & 0.0417 & 0.0000 & 0.0370 & 0.0000 & 0.0400 & 0.0909\end{array}$
11
12
13
14
15
16
17
18
1920

Jaccard

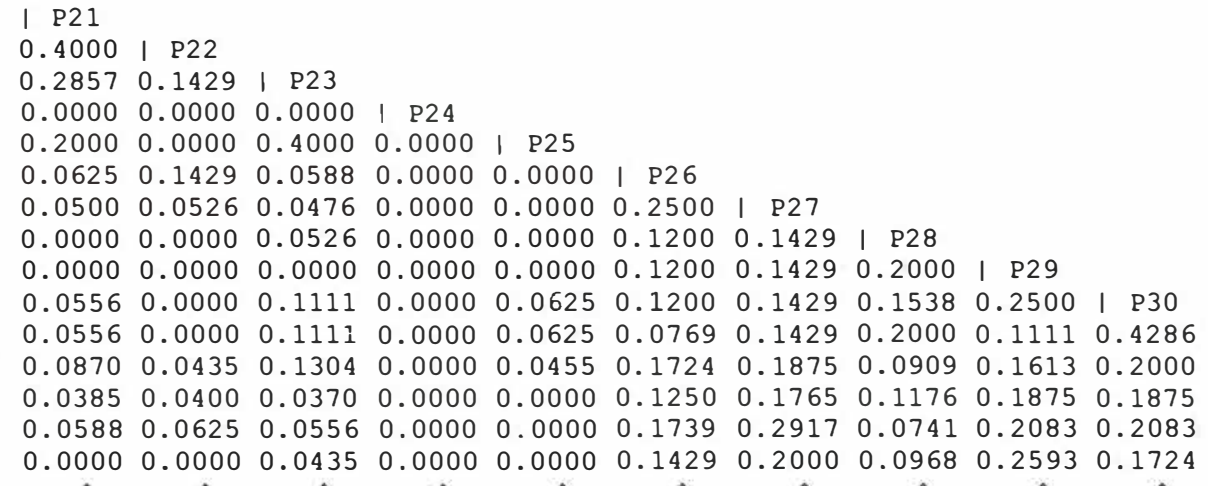
21
22
23
24
25
26
27
28
29
30

Jaccard

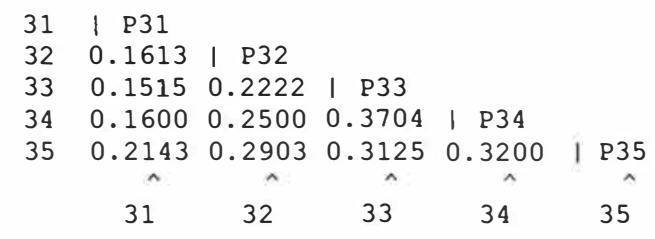

Tipo de coeficiente :Jaccard

* Correlacao cofenetica $=0.8000$

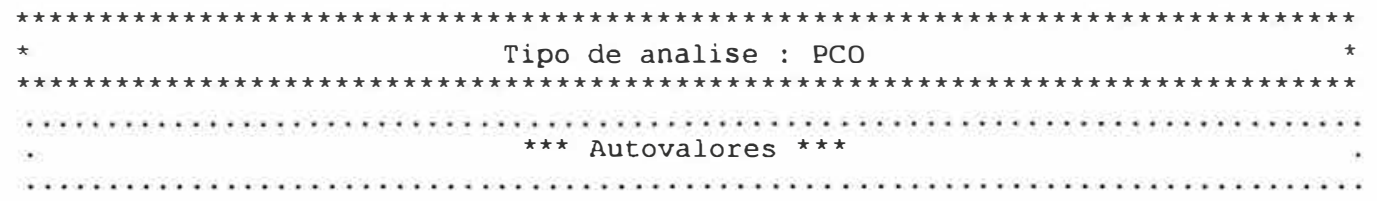

Traco da matriz $=31.09419$

$\begin{array}{lr} & \text { autovalor } \\ 1 & 2.66803 \\ 2 & 2.18379 \\ 3 & 1.77797\end{array}$


Eixos

Par Eixo 1 Eixo 2 Eixo 3

P1. $0.0140 \quad 0.1365-0.1935$

P2. $\quad \begin{array}{llll}0.1115 & 0.3269 & 0.0339\end{array}$

$\begin{array}{llll}\text { P3. } & 0.0767 & 0.1379 & -0.1174\end{array}$

$\begin{array}{lllll}\text { P4. } & 0.1151 & 0.2151 & -0.2197\end{array}$

$\begin{array}{llll}\text { P5. } & 0.1290 & 0.0900 & 0.3657\end{array}$

$\begin{array}{llll}\text { P6. } & 0.1900 & -0.0318 & -0.1908\end{array}$

$\begin{array}{llll}\text { P7. } & 0.0826 & -0.1778 & 0.0982\end{array}$

P8. $\quad 0.1300-0.2446-0.1982$

P9. $\quad 0.0613-0.1531-0.0734$

$\begin{array}{lllll}\text { P10 } & 0.1441 & 0.0767 & -0.0675\end{array}$

$\begin{array}{llll}\text { P11 } & 0.1289 & 0.3528 & 0.0996\end{array}$

$\begin{array}{llll}\mathrm{P} 12 & 0.1189 & 0.1981 & 0.3538\end{array}$

$\begin{array}{llll}\text { P13 } & 0.1532 & 0.0767 & 0.1023\end{array}$

$\begin{array}{llll}\mathrm{P} 14 & 0.0425 & 0.0231 & 0.2375\end{array}$

$\begin{array}{llll}\text { P15 } & 0.1045 & -0.0295 & 0.1492\end{array}$

$\begin{array}{llll}\text { P16 } & 0.1217 & 0.0237 & 0.1441\end{array}$

$\begin{array}{llll}\text { P17 } & 0.1166 & -0.0571 & -0.1118\end{array}$

$\begin{array}{lllll}\text { P18 } & 0.1472 & -0.2377 & 0.1499\end{array}$

$\begin{array}{lllll}\mathrm{P} 19 & 0.1688 & 0.1376 & -0.3342\end{array}$

$\begin{array}{lllll}\text { P20 } & 0.0744 & 0.2507 & -0.0476\end{array}$

$\begin{array}{lllll}\text { P21 } & 0.1422 & -0.3856 & 0.0355\end{array}$

$\begin{array}{lllll}\text { P22 } & 0.1438 & -0.2694 & -0.3224\end{array}$

$\begin{array}{lllll}\text { P23 } & 0.0238 & -0.2623 & 0.0881\end{array}$

$\begin{array}{llll}\text { P24 } & -0.0412 & -0.0046 & 0.0590\end{array}$

$\begin{array}{lllll}\text { P25 } & 0.0332 & -0.2479 & 0.1794\end{array}$

$\begin{array}{lllll}\text { P26 } & -0.1182 & 0.0525 & -0.2382\end{array}$

$\begin{array}{lllll}\text { P27 } & -0.2384 & 0.0272 & -0.1199\end{array}$

$\begin{array}{llll}\text { P28 } & -0.2088 & 0.0030 & 0.0695\end{array}$

$\begin{array}{lllll}\text { P29 } & -0.2815 & 0.0131 & 0.0180\end{array}$

$\begin{array}{llll}\text { P30 } & -0.2851 & -0.0517 & 0.1310\end{array}$

$\begin{array}{llll}\text { P31 } & -0.2650 & -0.0590 & 0.1386\end{array}$

$\begin{array}{llll}\text { P32 } & -0.2310 & -0.0077 & -0.0245\end{array}$

$\begin{array}{lllll}\text { P33 } & -0.2835 & 0.0303 & -0.0742\end{array}$

$\begin{array}{lllll}\text { P34 } & -0.3103 & -0.0127 & -0.0905\end{array}$

$\begin{array}{lllll}\text { P35 } & -0.3111 & 0.0607 & -0.0293\end{array}$

Eixos (X 1000)

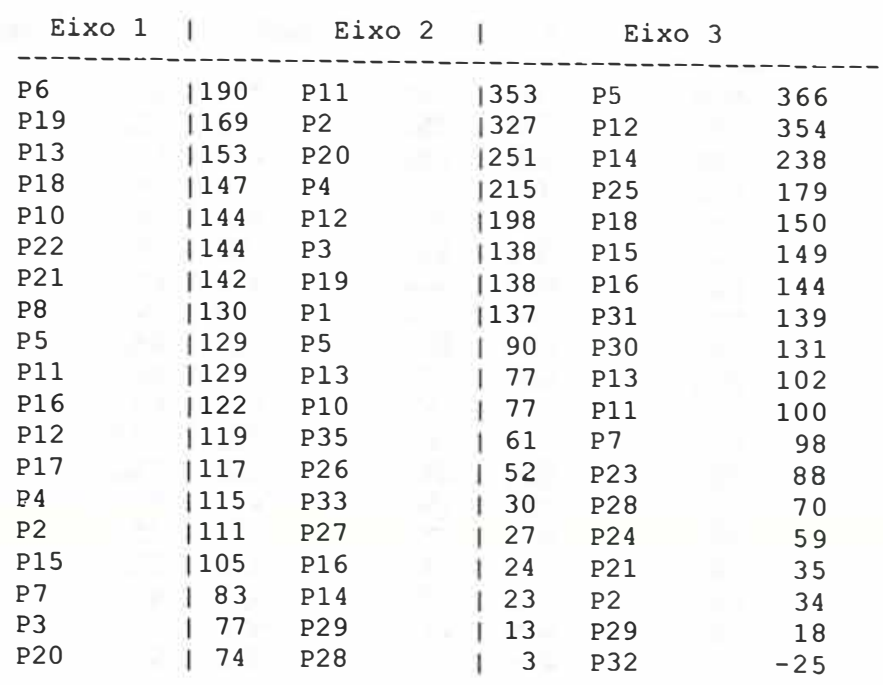




$\begin{array}{llllllll}\text { P9 } & 61 & \text { P24 } & -5 & \text { P35 } & -29 \\ \text { P14 } & 43 & \text { P32 } & -8 & \text { P20 } & -48 \\ \text { P25 } & 33 & \text { P34 } & -13 & \text { P10 } & -67 \\ \text { P23 } & 24 & \text { P15 } & -29 & \text { P9 } & -73 \\ \text { P1 } & 14 & \text { P6 } & -32 & \text { P33 } & -74 \\ \text { P24 } & -41 & \text { P30 } & -52 & \text { P34 } & -91 \\ \text { P26 } & -118 & \text { P17 } & -57 & \text { P17 } & -112 \\ \text { P28 } & 1-209 & \text { P31 } & -59 & \text { P3 } & -117 \\ \text { P32 } & 1-231 & \text { P9 } & -153 & \text { P27 } & -120 \\ \text { P27 } & 1238 & \text { P7 } & -178 & \text { P6 } & -191 \\ \text { P31 } & 1-265 & \text { P18 } & -238 & \text { P1 } & -193 \\ \text { P29 } & 1-282 & \text { P8 } & -245 & \text { P8 } & -198 \\ \text { P33 } & -283 & \text { P25 } & -248 & \text { P4 } & -220 \\ \text { P30 } & -285 & \text { P23 } & -262 & \text { P26 } & -238 \\ \text { P34 } & 1-310 & \text { P22 } & -269 & \text { P22 } & -322 \\ \text { P35 } & -311 & \text { P21 } & -386 & \text { P19 } & -334\end{array}$

\begin{tabular}{lrrr}
\multicolumn{4}{c}{ Autovetor } \\
Par & Eixo 1 & Eixo 2 & \multicolumn{1}{r}{ Eixo 3} \\
\hline P1. & 0.0228 & 0.2017 & -0.2580 \\
P2. & 0.1821 & 0.4831 & 0.0452 \\
P3. & 0.1253 & 0.2038 & -0.1566 \\
P4. & 0.1880 & 0.3178 & -0.2930 \\
P5. & 0.2107 & 0.1330 & 0.4876 \\
P6. & 0.3104 & -0.0470 & -0.2544 \\
P7. & 0.1349 & -0.2628 & 0.1309 \\
P8. & 0.2123 & -0.3615 & -0.2643 \\
P9. & 0.1001 & -0.2263 & -0.0979 \\
P10 & 0.2354 & 0.1133 & -0.0899 \\
P11 & 0.2105 & 0.5213 & 0.1328 \\
P12 & 0.1942 & 0.2927 & 0.4718 \\
P13 & 0.2503 & 0.1134 & 0.1364 \\
P14 & 0.0695 & 0.0341 & 0.3167 \\
P15 & 0.1707 & -0.0436 & 0.1990 \\
P16 & 0.1988 & 0.0350 & 0.1922 \\
P17 & 0.1905 & -0.0844 & -0.1491 \\
P18 & 0.2405 & -0.3513 & 0.1999 \\
P19 & 0.2757 & 0.2034 & -0.4456 \\
P20 & 0.1216 & 0.3705 & -0.0635 \\
P21 & 0.2322 & -0.5698 & 0.0473 \\
P22 & 0.2348 & -0.3980 & -0.4299 \\
P23 & 0.0389 & -0.3876 & 0.1175 \\
P24 & -0.0673 & -0.0068 & 0.0786 \\
P25 & 0.0543 & -0.3664 & 0.2392 \\
P26 & -0.1931 & 0.0775 & -0.3176 \\
P27 & -0.3893 & 0.0402 & -0.1599 \\
P28 & -0.3411 & 0.0044 & 0.0927 \\
P29 & -0.4598 & 0.0194 & 0.0240 \\
P30 & -0.4657 & -0.0764 & 0.1747 \\
P31 & -0.4329 & -0.0872 & 0.1848 \\
P32 & -0.3773 & -0.0113 & -0.0327 \\
P33 & -0.4630 & 0.0448 & -0.0989 \\
P34 & -0.5068 & -0.0187 & -0.1207 \\
P35 & -0.5082 & 0.0898 & -0.0391
\end{tabular}


Autovetor (X 1000)

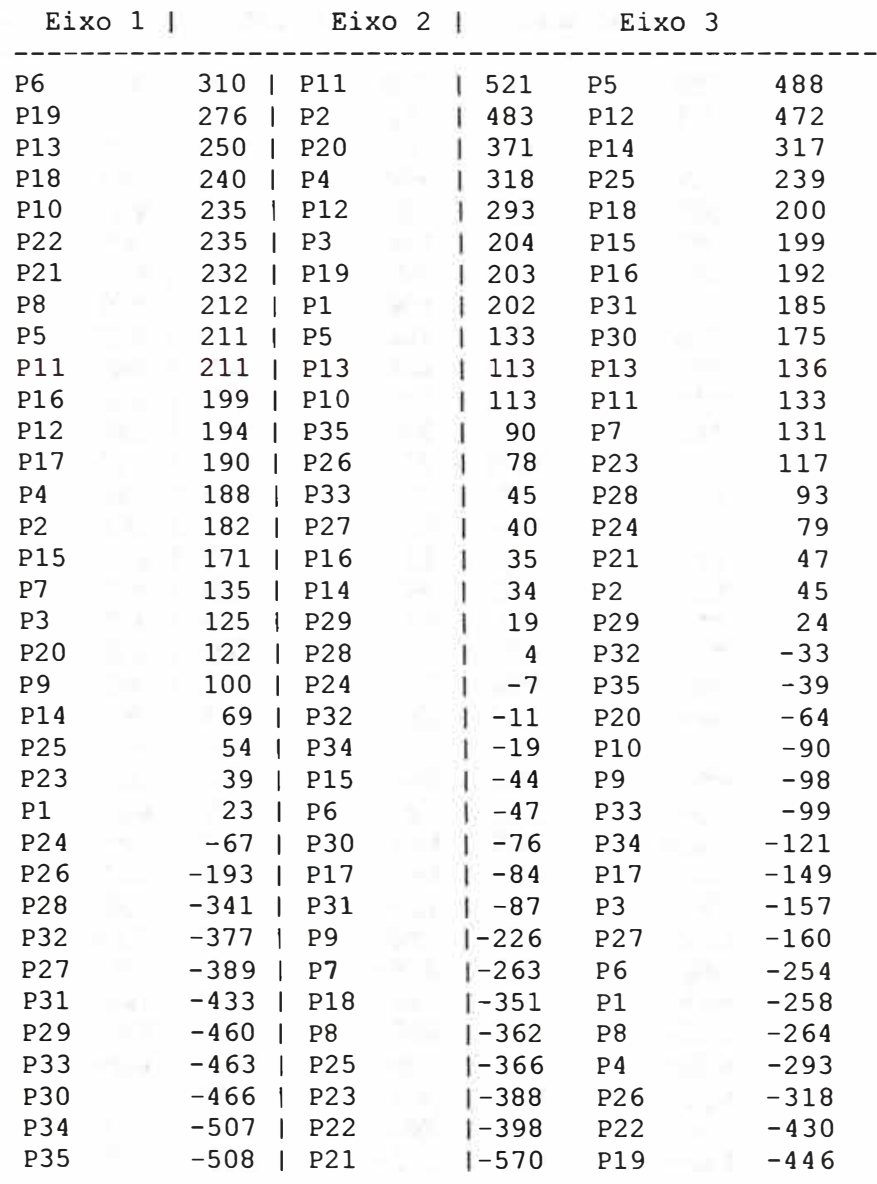

Eixo 1

Pontos sobrepostos (*) ou sem espa

\begin{tabular}{|c|c|c|c|c|}
\hline$\$ \mathrm{P} 10 \quad$ Nome & $\begin{array}{l}\text { linha } \\
20\end{array}$ & $\begin{array}{l}\text { coluna } \\
51\end{array}$ & $\begin{array}{c}\text { valor }-\mathrm{x} \\
0.2354\end{array}$ & $\begin{array}{r}\text { valor-y } \\
0.1133\end{array}$ \\
\hline
\end{tabular}


ANEXO L: Análise química do solo (exceto micronutrientes) para as duas áreas comparadas (A12 - SAF e A0 - Capoeira), município de Ituberá, Bahia, Brasil.

\begin{tabular}{|c|c|c|c|c|c|c|c|c|c|c|c|c|c|c|c|}
\hline & $\begin{array}{r}\mathrm{pH} \\
\mathrm{H} 2 \mathrm{O}\end{array}$ & $\begin{array}{r}\mathrm{pH} \\
\mathrm{KCl}\end{array}$ & $\begin{array}{c}\mathrm{pH} \\
\mathrm{Ca} \mathrm{Cl}{ }_{2}\end{array}$ & $\begin{array}{l}\text { M.O } \\
\% 0\end{array}$ & $\begin{array}{c}P \\
\mathrm{ppm}\end{array}$ & \multicolumn{8}{|c|}{ Mmoic $/ \mathrm{Kg}=\mathrm{meq} / 100 \mathrm{~cm} 3 \times 10$} & V\% & $\begin{array}{l}m \% \\
\text { Alx10 } \\
\text { ort }\end{array}$ \\
\hline \multicolumn{16}{|l|}{ Al2-SAF } \\
\hline prof. 0-5 & 5,59 & 5,49 & 5.42 & 170,9 & 29,0 & 1.6 & 110 & 82 & 25 & 0 & 38,6 & 194,8 & 232,2 & 83,4 & 0 \\
\hline prof. 5-20 & 5,39 & 4,96 & 4,82 & 42.7 & 12,9 & 0,8 & 45.3 & 27,1 & 162 & 1,5 & 58,6 & 73,2 & 131,8 & 54,7 & 2,8 \\
\hline prof. $40-60$ & 5,10 & 4,50 & 4.29 & 22.0 & 2,7 & 0,3 & 9,9 & 5,8 & 25 & 5,2 & 53,8 & 16,0 & 69,8 & 22,9 & 27,2 \\
\hline \multicolumn{16}{|c|}{ A0-Capoeira } \\
\hline prof. 0-5 & 5,28 & 4,57 & 4,57 & 190,4 & 4 & 1,7 & 54,6 & 17,0 & 23 & 3,7 & 109,4 & 73,4 & 182,7 & 41,1 & 5,8 \\
\hline prof. 5-20 & 5,05 & 4,09 & 4,09 & 44,84 & 2,96 & 0,9 & 13,1 & 6,3 & 148 & 9,3 & 99,6 & 20,3 & 120,0 & 17,5 & 33,76 \\
\hline prof. $40-60$ & 5,07 & 4,20 & 4,20 & 23,44 & 2,24 & 0,3 & 3,7 & 1,5 & 18 & 7,0 & 67,1 & 5,5 & 72,5 & 7,9 & 56,4 \\
\hline
\end{tabular}

Obs - os dados relativos a $\mathrm{S}_{-} \mathrm{SO}_{4}$ tem como unidade $\mathrm{mg} / \mathrm{dm}^{3}$ e cada profundidade amostrada (para este nutriente) é proveniente de uma amostra composta de cinco subamostras por área $(0,5$ ha). Para os outros atributos da fertilidade do solo, os dados são provenientes da média de 25 amostras compostas de 3 (obtidas de ácordo com a metodologia descrita para coleta de solo).

ANEXO M - Análise química do solo (referente a micronutrientes), em $\mathrm{mg} / \mathrm{dm}^{3}$, para as duas áreas comparadas (A12 - SAF e A0 - Capoeira), município de Ituberá, Bahia, Brasil.

\begin{tabular}{c|cc|cc|cc|cc|cc|cc}
\hline Prof. & \multicolumn{3}{|c|}{ B } & \multicolumn{2}{c|}{$\mathrm{Cu}$} & \multicolumn{3}{c|}{ Fe } & \multicolumn{3}{c|}{ Mb } & \multicolumn{2}{c|}{ Zn } & \multicolumn{2}{c}{ Na } \\
\hline (cm) & A0 & A12 & A0 & A12 & A0 & A12 & A0 & A12 & A0 & A12 & A0 & A12 \\
\hline $0-5$ & 0,37 & 0,70 & 0,3 & 1,4 & 113,0 & 96,2 & 1,0 & 4,2 & 0,2 & 0,6 & 11,50 & 13,80 \\
$5-20$ & 0,49 & 0,62 & 0,1 & 0,5 & 118,0 & 36,8 & 0,1 & 0,3 & 0,1 & 0,1 & 6,90 & 4,60 \\
$40-60$ & 0,02 & 0.23 & 0.2 & 1,1 & 14.2 & 59.2 & 1.0 & 1,1 & 1.0 & 1.0 & 0,00 & 4,60 \\
\hline
\end{tabular}


ANEXO N - Valores das médias para três profundidades do solo, comparando com teste estatístico t-Student pareado, as duas áreas estudadas (A10 - SAF e A0 - Capoeira), município de Ituberá, Bahia, Brasil:

\begin{tabular}{|c|c|c|c|c|c|c|c|}
\hline & & & $\mathrm{A} 0$ & & 12 & Teste $\mathrm{t}-\mathrm{stu}$ & pareado \\
\hline & profundidade & média & $\mathrm{CV}$ & média & $\mathrm{CV}$ & T calculado & sig \\
\hline & $0-5$ & 5,28 & 4,859 & 5,592 & 2,577 & $-5,592$ & $* *$ \\
\hline $\mathrm{pH}-\mathrm{H} 2 \mathrm{O}$ & $5-20$ & 5,052 & 5,364 & 5,392 & 4,477 & $-4,6844$ & $* *$ \\
\hline & $40-60$ & 5,068 & 3,208 & 5,096 & 3,944 & $-0,5415$ & ns \\
\hline & $0-5$ & 4,424 & 4,037 & 5,496 & 3,805 & $-19,4898$ & ** \\
\hline $\mathrm{pH}-\mathrm{KCl}$ & $5-20$ & 4,216 & 2,623 & 4,964 & 8,525 & $-8,5509$ & ** \\
\hline & $40-60$ & 4,428 & 1,903 & 4,500 & 4,843 & $-1,5407$ & ns \\
\hline & $0-5$ & 4,516 & 4,639 & 5,42 & 4,227 & $-14,5579$ & $* *$ \\
\hline $\mathrm{pH}-\mathrm{CaCl} 2$ & $5-20$ & 4,092 & 4,169 & 4,824 & 7,163 & $-9,4977$ & ** \\
\hline & $40-60$ & 4,200 & 2,280 & 4,292 & 4,799 & $-2,025$ & ns \\
\hline & $0-5$ & 190,4 & 3,042 & 170,88 & 29,922 & 1,2634 & ns \\
\hline M.O & $5-20$ & 44,84 & 10,434 & 42,72 & 15,550 & 1,3046 & ns \\
\hline & $40-60$ & 23,44 & 22,944 & 22,04 & 19,092 & 1,0250 & ns \\
\hline & $0-5$ & 4 & 35,355 & 29,04 & 29,345 & $-14,4933$ & ** \\
\hline $\mathrm{P}(\mathrm{ppm})$ & $5-20$ & 2,96 & 44,135 & 12,92 & 30,547 & $-11,9789$ & ** \\
\hline & $40-60$ & 2,24 & 59,449 & 2,68 & 31,808 & $-1,3914$ & ns \\
\hline & $0-5$ & 1,736 & 30,476 & 1,604 & 31,610 & 0,9007 & ns \\
\hline $\mathrm{K}$ (mmolc) & $5-20$ & 0,872 & 37,821 & 0,780 & 36,073 & 1,0611 & ns \\
\hline & $40-60$ & 0,256 & 43,790 & 0,324 & 44,797 & $-1,8539$ & ns \\
\hline & $0-5$ & 54,6 & 34,569 & 110 & 21,547 & $-9,1424$ & $* *$ \\
\hline $\mathrm{Ca}$ (mmolc) & $5-20$ & 13,12 & 53,095 & 45,28 & 35,494 & $-9,1800$ & ** \\
\hline & $40-60$ & 3,68 & 32,076 & 9,92 & 50,815 & $-6,0264$ & $* *$ \\
\hline & $0-5$ & 17,04 & 28,824 & 82 & 10,414 & $-32,9716$ & $* *$ \\
\hline $\mathrm{Mg}$ (mmolc) & $5-20$ & 6,32 & 37,588 & 27,12 & 36,274 & $-10,2764$ & ** \\
\hline & $40-60$ & 1,52 & 63,331 & 5,76 & 40,493 & $-8,4019$ & $* *$ \\
\hline & $0-5$ & 3,72 & 75,840 & 0 & 0 & 6,5926 & $* *$ \\
\hline $\mathrm{Al}$ (mmolc) & $5-20$ & 9,28 & 41,090 & 1,48 & 110,540 & 9,3800 & ** \\
\hline & $40-60$ & 9,96 & 27,000 & 5,16 & 43,930 & 3,0550 & $*$ \\
\hline & $0-5$ & 109,36 & 42,590 & 38,6 & 25,840 & 7,4263 & ** \\
\hline $\mathrm{H}+\mathrm{Al}$ & $5-20$ & 99,64 & 33,630 & 58,64 & 29,500 & 5,4350 & $* *$ \\
\hline (mmolc) & $40-60$ & 67,08 & 25,049 & 53,76 & 22,580 & 3,2126 & $*$ \\
\hline & $0-5$ & 73,376 & 31,860 & 194,804 & 15,563 & $-15,8592$ & ** \\
\hline $\mathrm{SB}$ (mmolc) & $5-20$ & 20,312 & 45,211 & 73,180 & 33,547 & $-10,0850$ & $* *$ \\
\hline & $40-60$ & 5.456 & 35,442 & 16,004 & 43,808 & $-7,2516$ & $* *$ \\
\hline
\end{tabular}




\begin{tabular}{|c|c|c|c|c|c|c|c|}
\hline & & \multicolumn{2}{|r|}{ A0 } & \multicolumn{2}{|c|}{ Al2 } & \multicolumn{2}{|c|}{ Teste $\mathrm{t}$-student pareado } \\
\hline & profundidade & média & $\mathrm{CV}$ & média & $\mathrm{CV}$ & T calculado & sig \\
\hline & $0-5$ & 182,736 & 26,926 & 232,204 & 14,831 & $-4,1184$ & $*$ \\
\hline $\mathrm{T}$ & $5-20$ & 119,952 & 26,685 & 131,82 & 13,788 & $-1,6121$ & ns \\
\hline$\left(\mathrm{mmolc} / 100 \mathrm{~cm}^{3}\right)$ & $40-60$ & 72,536 & 22,904 & 69,764 & 19,366 & 0,6472 & ns \\
\hline \multirow{3}{*}{ V\% } & $0-5$ & 41,12 & 29,293 & 83,44 & 39,154 & $-16,9533$ & ** \\
\hline & $5-20$ & 17,52 & 49,762 & 54,72 & 25,397 & $-11,3377$ & $* *$ \\
\hline & $40-60$ & 7,92 & 43,114 & 22,92 & 37,846 & $-8,0453$ & $* *$ \\
\hline \multirow{3}{*}{$\mathrm{M} \%$} & $0-5$ & 5,8 & 91,900 & 0 & 0 & 5,4402 & ** \\
\hline & $5-20$ & 33,76 & 48,500 & 2,76 & 117,900 & 9,2705 & ** \\
\hline & $40-60$ & 56,4 & 19,000 & 27,24 & 55,600 & 7,7700 & $* *$ \\
\hline
\end{tabular}

ANEXO 0 - Coprólito de minhocuçu (Rhinodrillus sp.), encontrado na área manejada (A12).

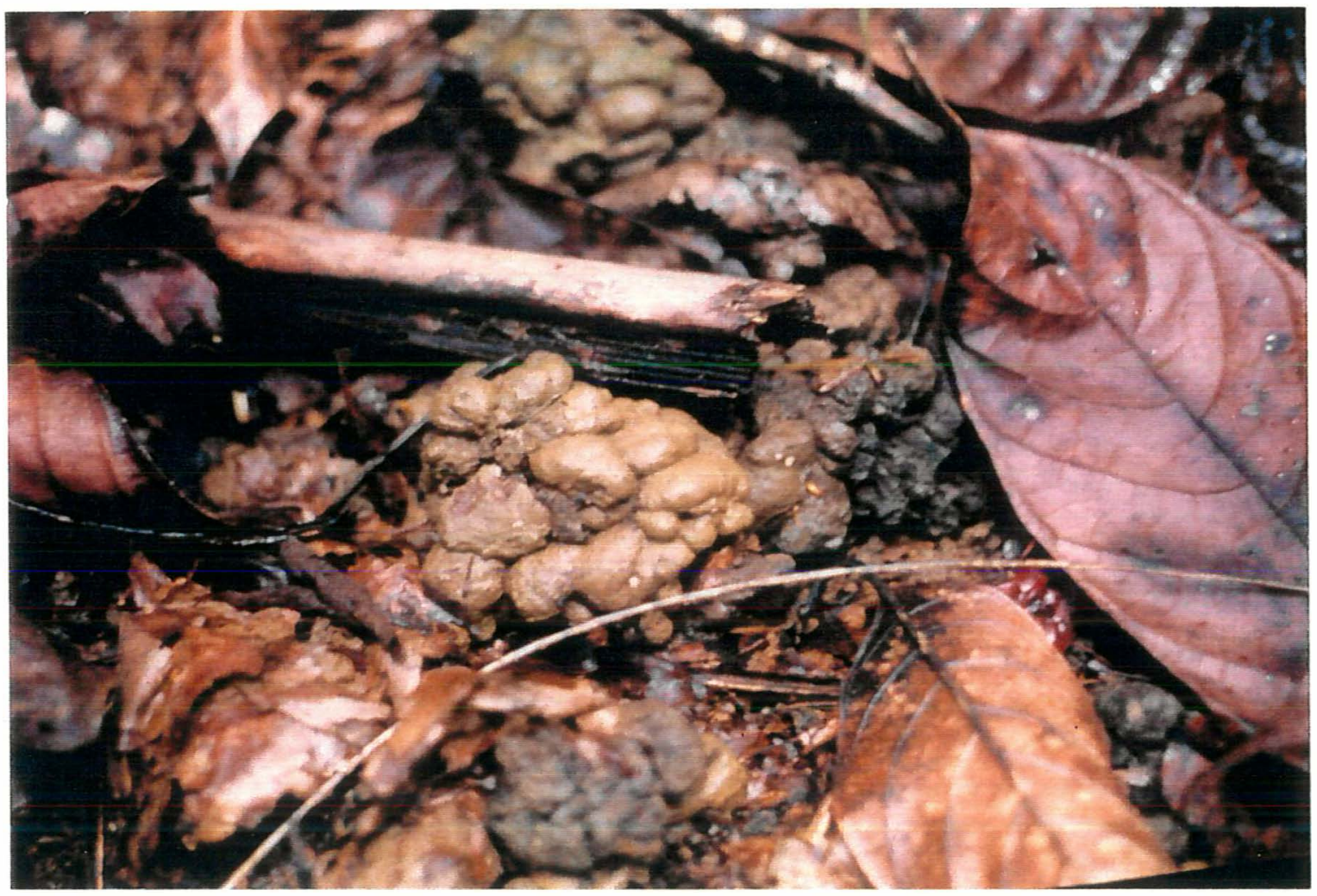


ANEXO P - Conteúdo de folhas e tocos da serapilheira para as duas áreas estudadas A0 capoeira e A12 - SAF, em Kg/ha, município de Ituberá, Bahia, Brasil.

\begin{tabular}{lcc}
\hline & A0 & A12 \\
\hline Peso seco folhas (kg/ha) & 15059,2 & 14377,07 \\
\hline Peso seco tocos $(\mathrm{kg} / \mathrm{ha})$ & 3800,43 & 6251,15 \\
\hline
\end{tabular}

ANEXO S - Teores de nutrientes nas folhas da serapilheira (em $\mathrm{Kg} / \mathrm{ha}$ ) para as duas áreas estudadas (A0 e A12), município de Ituberá, Brahia, Brasil.

\begin{tabular}{lcccccc}
\hline Área & $\mathrm{Ca}$ & $\mathrm{Mg}$ & $\mathrm{N}$ & $\mathrm{P}_{2} \mathrm{O}_{5}$ & $\mathrm{~K}_{2} \mathrm{O}$ & $\mathrm{S}$ \\
\hline $\mathrm{A} 12$ & 243,87 & 59,70 & 233,28 & 12,89 & 22,66 & 9,68 \\
$\mathrm{AO}$ & 248,07 & 20,50 & 191,68 & 1,81 & 10,68 & 13,16 \\
\hline
\end{tabular}

ANEXO T - Teores em porcentagem dos macronutriente presentes na serapilheira (folhas) para as duas áreas estudadas (A12 - SAF e A0- Capoeira), município de Ituberá, Bahia, Brasil.
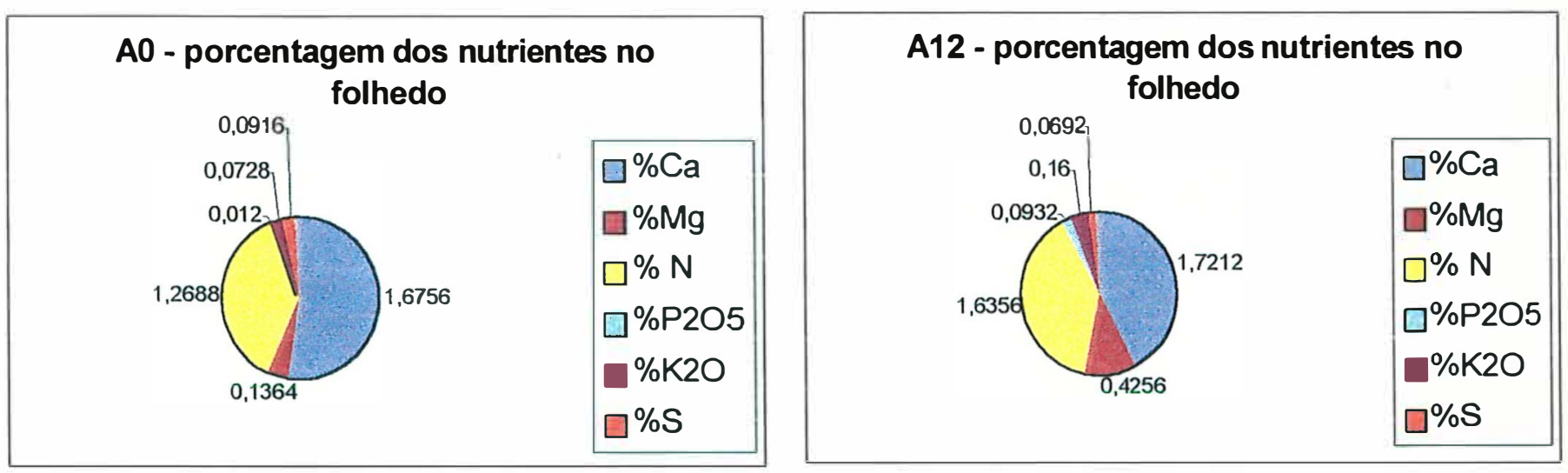
ANEXO Q - Quantidade média de material acumulado e respectivos conteúdos de elementos (\%), nos tocos da serapilheira coletada, para as duas áreas estudadas (A0 capoeira e A10-SAF), seguido da análise estatística (teste t Student)

\begin{tabular}{|c|c|c|c|c|c|}
\hline & \multicolumn{2}{|c|}{$\mathrm{A} 0$} & \multirow[t]{2}{*}{ Significância } & \multicolumn{2}{|c|}{ Al2 } \\
\hline & média & $\mathrm{CV}$ & & média & $\mathrm{CV}$ \\
\hline Peso seco & 0,285 & & ns & 0,469 & \\
\hline $\mathrm{pH}-\mathrm{CaCl} 2$ & 4,559 & 16,365 & $* *$ & 5,021 & 13,664 \\
\hline $\mathrm{N} \%$ & 0,631 & 30,671 & $* *$ & 0,954 & 28,233 \\
\hline P2O5 \% & 0,0164 & 63.243 & $* *$ & 0,0121 & 48,681 \\
\hline $\mathrm{K} 2 \mathrm{O} \%$ & 0,076 & 130,164 & $* *$ & 0,232 & 103,161 \\
\hline $\mathrm{Ca} \%$ & 0,929 & 58,854 & ns & 0,956 & 41,311 \\
\hline Mg \% & 0,0912 & 50,706 & $* *$ & 0,2300 & 36,624 \\
\hline S \% & 0,0664 & 57,060 & ns & 0,0813 & 37,597 \\
\hline $\mathrm{C} / \mathrm{N}$ & 70,77 & 28,168 & $* *$ & 48,74 & 18,354 \\
\hline
\end{tabular}

ANEXO R - Peso seco dos tocos da serapilheira para as duas áreas comparadas (A12 SAF e A0 - Capoeira), município de Ituberá, Bahia. Brasil.

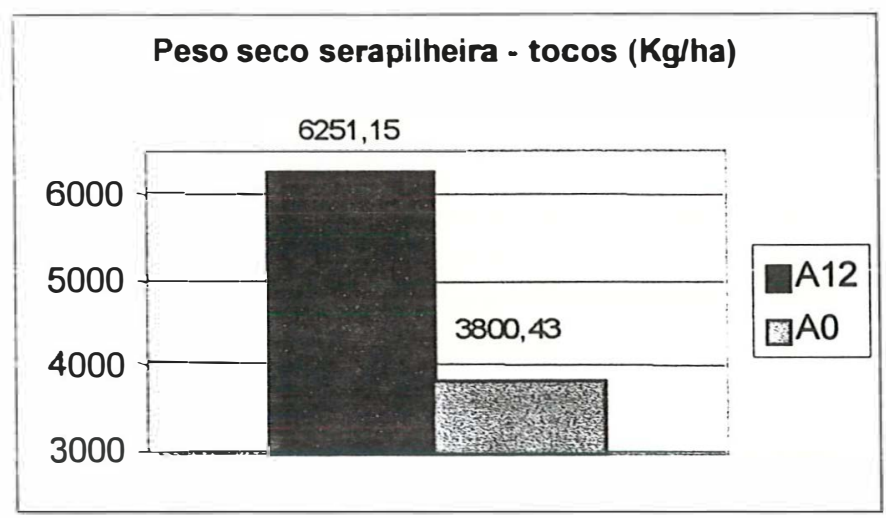




\section{ANEXO U - SAF dirigido pela (ou inspirado na) sucessão natural}

\section{Fundamento teórico desenvolvido por Ernst Götsch}

Com o propósito de apresentar suas idéias, essência deste estudo de caso, com confiabilidade e muito mais precisão, optou-se por mostrá-las na íntegra, como o próprio mentor as apresentou. Assim, segue a citação de E.G.:

"Estou tentando criar, em cada parte do mundo onde intervenho como agricultor, agroecossistemas que sejam parecidos, na sua estrutura (ou sua forma de funcionar) e na dinâmica, ao ecossistema natural e original do lugar. Ao mesmo tempo, tento deixar como resultado de todas as minhas intervenções (operações), um resultado positivo no balanço de vida e de energia complexificada em carbono, tanto no subsistema da minha intervenção, quanto no macroorganismo Planeta Terra. Ou, em outras palavras: para cada passo que ando e para tudo em que intervenho, previamente me pergunto: o que posso fazer para que, como resultado da minha presença e das minhas intervenções nasça $(m)$, se desenvolva $(m)$ um sistema (sistemas) mais próspero(s), mais vida com toda a sua abundância e mais complexidade em todos os seus aspectos no Planeta Terra, do qual somos parte, e não mais importantes do que todas as outras espécies. Isto significa que, em todas as suas implicações e conseqüências, estritamente, nos comportamos conforme o imperativo categórico de Kant ${ }^{10 »}$ (Götsch, E. comunicação pessoal, 1998).

\footnotetext{
10 "Imperativo categórico" de Kant: forma à priori de todas as leis morais que distingue das máximas ou regras da sensibilidade, dando-lhes o valor de obrigação absoluta, como os conceitos dão aos fenômenos o seu valor científico. Na Razão Prática encontra-se uma espécie de categoria, ou forma à priori cujo funcionamento depende da estrutura fundamental da natureza humana e que assim pode impor-se a todos os atos humanos e a todos os homens, para constituir a moral universal e necessária. O imperativo categórico é universal e não poderia mudar com as circunstâncias. Pressupõe obrigação pura, que exige para todo ato mralmente bom o desinteresse absoluto, o dever cumprido simplesmente pelo dever. Por meio do imperativo categórico, a Razão Prática formula um juízo sintético à priori fundamental, princípio supremo que confere um valor moral a todas as leis particulares. Kant deu desse imperativo três fórmulas: 1) "Age de tal modo que a tua ação possa servir de regra universal"; 2) "Age sempre de forma a tratar a humanidade, na tua pessoa como na dos outros, como um fim e nunca como um simples meio..."; 3) "Age de tal maneira que tua vontade possa considerar-se como estabelecendo, pelas suas máximas, leis universais” (Thonnard, 1968).
} 


\section{O MÉTODO - fundamento filosófico/teórico}

"O Planeta Terra é um macroorganismo cuja estratégia de ser é a transformação de energia oriunda do universo, na forma de radiação, em matéria. No caso do Planeta Terra, esta radiação vem primordialmente do nosso sol com o qual o Planeta Terra (como todos os outros planetas do nosso sistema solar) vive numa relação polar/complementar, de inspiração - SINTROPIA (Planeta Terra) e de expiração - ENTROPIA (sol).

A vida do nosso planeta faz parte do instrumentário dele no prosseguimento, na realização, da sua estratégia de ser. Ela (a vida) participa na materialização de energia de radiação [de uma parte dos raios solares que o Planeta Terra, mediante a sua ionosfera, recolhe, separa e canaliza para os diferentes usos (a partir daquela parte que ele deixa passar para a atmosfera), filtrando-a, mediante a atmosfera, para a biosfera, e refletindo a parte "indigerível" para o universo. Ela (a vida) complexifica a energia em matéria orgânica no macro - materialmente, e a organiza em sistemas auto-organizadores e autoreguladores (de vida) no micro - espiritualmente.

Mediante a sucessão natural, a vida se move no tempo e no espaço, sempre modificando-se, diferenciando-se, para englobar e para organizar o máximo possível de energia e de matéria em seus sistemas complexos, interligando-os em um só macroorganismo. A atmosfera, na sua atual composição, e a circulação de água são partes integrais deste macroorganismo (vida) e correspondem funcionalmente aos nossos sistemas respiratório e circulatório, respectivamente. Ambos resultam do metabolismo da vida.

Cada parte funcional do macroorganismo (vida), assim como cada espécie, têm sua existência e sobrevivência dependentes de cada um dos outros anéis (níveis tróficos, populações, indivíduos...) e cada uma surgiu, conceitualmente, na sua forma, para otimizar o metabolismo sintrópico do mesmo (do dito macroorganismo). Isto significa que é previsto que cada espécie deixe como resultado da sua presença e das suas intervenções um balanço positivo de vida e de energia complexificada.

O Planeta Terra armazena o excedente de energia materializada pela vida na forma de turfa, carvão, petróleo, gás natural, etc. Além disso, o Planeta Terra, por sua vez, 
favorece e otimiza, mediante um complexo instrumentário, a vida, e seus processos metabólicos:

1. Mediante a sua ionosfera, ele recebe e recolhe a totalidade do impacto de radiação oriunda do universo, a separa e, em seguida, canaliza cada uma das diferentes formas para o melhor aproveitamento;

2. Ele mantém o ângulo do seu eixo de rotação oblíquo em relação à sua elíptica, o que faz com que chegue, num modo cíclico, luz para cada parte do Planeta, que, por sua vez, tanto possibilita que haja fotossíntese em toda a sua superfície, como otimiza a função dos acima mencionados "aparelhos respiratório e circulatório";

3. Mediante processos geofísicos, por exemplo, através de vulcanismo (a), ele continuamente fornece, entre outros benefícios, os minerais necessários para que tenha vida próspera, ou através dos movimentos tectônicos (b), que são empregados para vários efeitos, citando alguns neste contexto, usados da mesma forma como através do vulcanismo:

- para um contínuo fornecimento de minerais à flora e à fauna (b1);

- para separar e - em seguida - armazenar o excedente de energia complexificada pela vida na forma de gás natural, petróleo, carvão mineral, etc, (b2);

- para ir transportanto os restos que ficam das rochas gastas por processos metabólicos de vida e entrópicos por impactos físicos autóctones e externos na superfície da sua crosta para o interior da manta do Planeta (b3);

- para que os "restos" (citados em b3) sejam "digeridos" e recomplexificados, para, futuramente, serem levados de volta à superfície, disponibilizando-os, assim, para novo uso (c).

O estudo desses fenômenos acima descritos ou citados, assim como a observação da dinâmica nos processos sucessionais durante 22 anos de extensos trabalhos em recuperação de solos degradados por efeitos de agromineração, em várias partes do mundo, implantando e criando nestes solos (lugares) agroecossistemas altamente produtivos e biodiversificados (na maioria dos casos sem o uso de insumos) me levaram cada vez a ver e a entender mais claramente que são dois principais vetores que fazem com que haja um contínuo crescimento e aumento de vida: 
O Vetor I resulta no caráter instrumental da vida, em relação ao Planeta Terra, no prosseguimento de sua forma estratégica sintrópica de ser, sendo, nesta tarefa, a parte da vida (os organismos) a materialização de uma parte da radiação que nós percebemos como luz, via fotossíntese, ou, em situações extremas, a materialização de calor via quimiossíntese. O contínuo aumento de vida resulta num excedente de assimilados que o Planeta Terra escoa, transformando-os em formas estáveis para armazená-los (turfa, carvão, petróleo, gás natural, etc.). Além disso, como acima descrito, mediante um eficiente e complexo instrumentário, favorece, adianta e otimiza os processos e o aumento de vida.

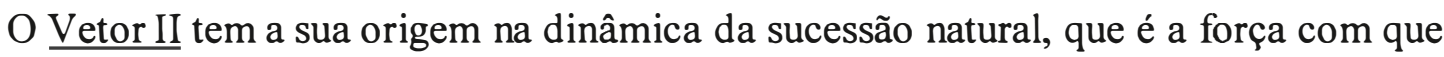
a vida se move no tempo e no espaço, criativamente evoluindo-se, sempre aspirando a englobar e a vivificar o máximo de matéria e de espaço, ampliando, aumentando e diversificando os nichos, produzindo, num processo de contínua procriação, organismos e redes de alta complexidade entre estes últimos e inter-relacionando-os com laços sinergéticos.

Cada espécie surge, cresce e então chega a dominar (ou faz parte de um consórcio dominante de espécies no seu lugar como resultado de uma, para a sua particularidade determinada, isso é necessária. quantidade e qualidade de vida consolidada. Cada ser vivo crescendo (aumento de vida), cumprindo a sua função, modifica o seu ambiente e, enquanto que faz desnecessária a sua própria presença, cria condições para as próximas formas determina o próximo consórcio de vida a aparecer, crescer e em seguida - dominar.

Ou, apresentando os mesmos processos de forma sumária: cada ser vivo aparece determinado por o que antecedeu e, vivendo, crescendo, cumprindo a sua função, modifica o seu ambiente e determina, assim, as condições para as próximas formas de vida a seguir e as cria.

Vejamos, neste contexto o significado e a altíssima importância da múltipla estratégia da natureza para assegurar, em cada situação, uma verdadeira sucessão:

- Além da sucessão entre as espécies, que implica uma grande diversidade, um grande número de espécies (biodiversidade mais visível morfologicamente) existe uma

- segunda forma de sucessão tão importante quanto a primeira, aquela entre as gerações das mesmas espécies. A implementação deste processo está sendo realizada via: 
- multiplicação sexual ou conjugação entre dois genótipos diferentes;

- heterozigosidade;

- fatores letais e sub-vitais recessivos que aparecem fenotipicamente em caso de consangüinidade;

- mutação;

- poliploidia.

Sabemos que a totalidade do instrumentário acima delineado funciona com toda a perfeição desde os lugares mais inóspitos até as situações mais privilegiadas para a vida; sendo que o máximo número das espécies aumenta no sentido das condições difíceis para as privilegiadas (o número de formas aumenta enquanto a complexidade da morfologia delas aumenta, porque o espaço físico englobado e a matéria envolvida nos biótopos aumentam, indo das zonas de vida menos privilegiadas para as mais privilegiadas).

No contrário, do privilegiado indo para o difícil, o número das espécies diminui. Em compensação, no entanto, a diversidade genética aumenta, o número de espécies envolvidas aumenta, assim como também a taxa (freqüência de ocorrência) de mutações e a poliploidia.

Vejamos também a armadilha que nós construímos para nós mesmos mediante o uso cada vez mais extenso de híbridos e clones com estreitíssima base genética, capina indiscriminada, agrotóxicos, substituição dos ecossistemas naturais por monoculturas, etc. Cada um destes fatores contribuindo para um empobrecimento e afunilamento da biodiversidade, i. e., material genético, riqueza, resultando (visível no seguinte gráfico) na nossa própria expulsão do Planeta.

Os dois vetores, o de aumento de vida (I) e da sucessão Natural (II), por sua vez, são intrinsecamente interligados numa interação contínua e dialética: os processos, as dinâmicas encadeadas pelo aumento de vida em si determinam que tenha sucessão e viceversa.

As dinâmicas resultando da interação destes dois vetores me inspiraram de ilustrálas no seguinte gráfico: 


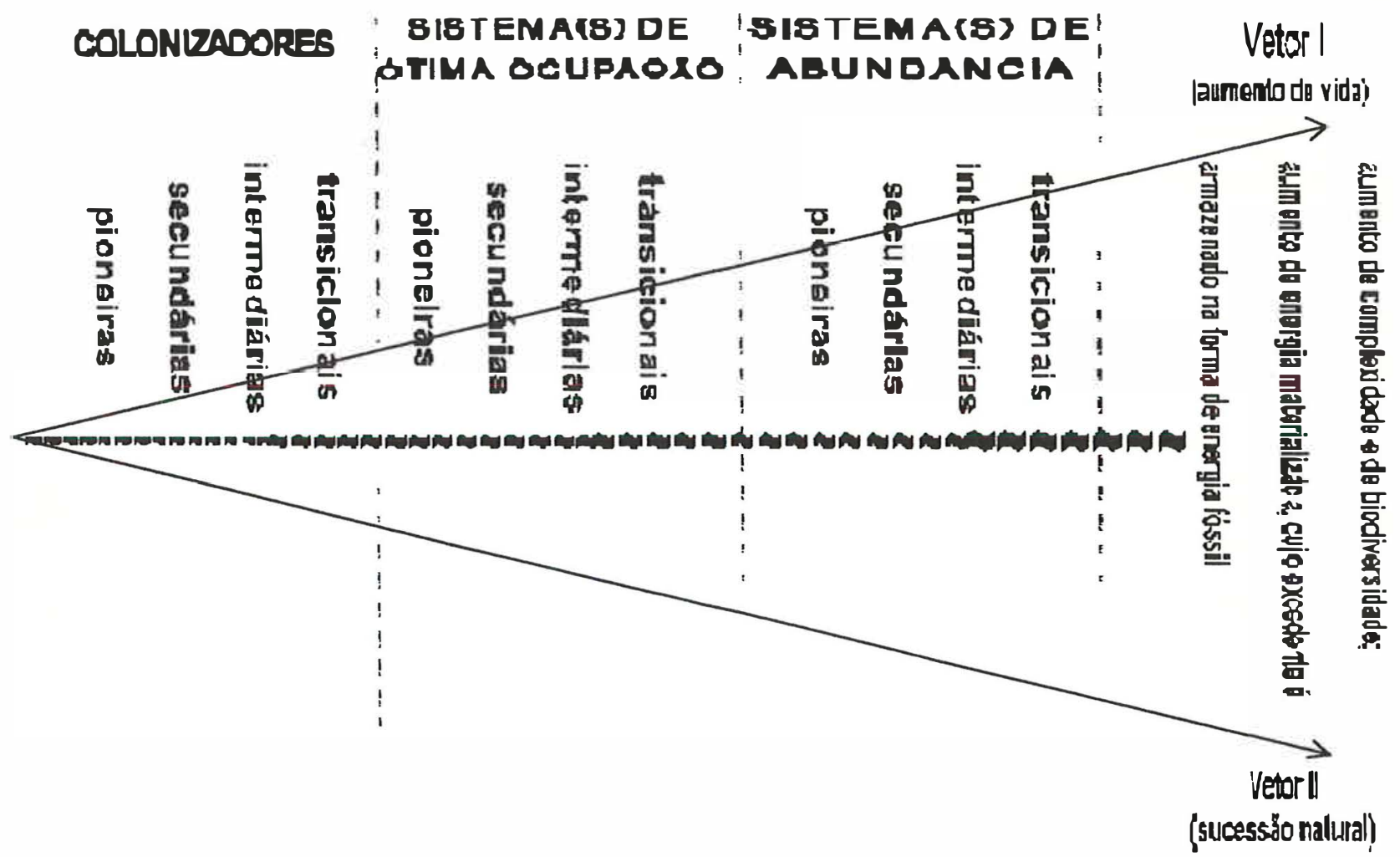

Figura U.1 - GRÁFICO VETORIAL DA VIDA (de Ernst Götsch)

\section{Quadro explicativo da Figura U.1:}

\begin{tabular}{|c|c|c|}
\hline Colonizadores & Sistemas de ótima ocupação & Sistemas de abundância \\
\hline $\begin{array}{l}\text { Criadores de condições de vida } \\
\text { (sendo por ex. as sulfobactérias os } \\
\text { mais extremos usando a } \\
\text { quimiossintese para preparar o } \\
\text { ambiente delas para outras formas } \\
\text { de vida). Criação das primeiras } \\
\text { redes. A tarefa de transformação } \\
\text { de matéria orgânica. na sua } \\
\text { maioria. é realizada por bactérias, } \\
\text { amebas e fungos. Assim a tarefa } \\
\text { de "cibernética" (otimização de } \\
\text { processos de vida - tarefa das tais } \\
\text { de "pragas e doenças") } \\
\text { aparência dos primeiros pequenos } \\
\text { animais na fase dos } \\
\text { intermediários + transicionais } \\
\text { com tarefa de transformação de } \\
\text { matéria orgânica. }\end{array}$ & $\begin{array}{l}\text { Alta acumulação de carbono em sistemas } \\
\text { de vida. Relação entre C/N ampla. } \\
\text { Criação de redes de alta complexidade. } \\
\text { Processos lentos de transformação de } \\
\text { matéria orgânica devida a relação ampla } \\
\text { entre C e N. Animais, em sua maioria. de } \\
\text { porte pequeno, cumprindo tare fas (posto } \\
\text { em ordem da sua importância quantitativa) } \\
\text { como: polinização. cibernética, } \\
\text { transformação de matéria orgânica. } \\
\text { distribuição de sementes e outros. O } \\
\text { excedente de energia materializada } \\
\text { passando para: I. sistemas de abundância } \\
\text { (por exemplo, nas ladeiras ingremes as } \\
\text { frações das copas vegetais a serem } \\
\text { transformadas descem por gra vidade para } \\
\text { o pé da ladeira - uma das situações típicas } \\
\text { para a ocorrência de sistemas de } \\
\text { abundância ou II. depositado a ser } \\
\text { transformado em turfa, lignite ( }{ }^{*} \text { carvão } \\
\text { proveniente de turfa), etc. }\end{array}$ & $\begin{array}{l}\text { Redes mais sensiveis a perturbações; altíssima } \\
\text { complexidade; devida à estreita relação entre } \\
\text { carbono e nitrogênio, rápidos e freqüentes os } \\
\text { processos de transformação. Lugar do homem } \\
\text { e o (lugar) da maior parte das suas plantas } \\
\text { cultivadas. Muitos animais e de todos os } \\
\text { portes; os de porte grande, no entanto, sendo a } \\
\text { peculiaridade destes sistemas (grandes } \\
\text { herbivoros. frugivoros e carnivoros ou } \\
\text { comedores de plâncto), cumprindo a função } \\
\text { cibernética de intermediadores (distribuição de } \\
\text { sementes) e - bastante importante- de } \\
\text { transformadores, de transportadores } \\
\text { excedentes de energia materializada dos } \\
\text { sistemas de abundância para os depósitos } \\
\text { (normalmente marinhos) i.e. pelos animais } \\
\text { terrestres para os rios pelos peixes (de água } \\
\text { doce), para o mar e pelos - animais marinhos } \\
\text { para os depósitos (lugares com altas } \\
\text { densidades de algas em vastas áreas. } \\
\text { normalmente nos trópicos). }\end{array}$ \\
\hline
\end{tabular}




\section{Terminologia usada:}

Para fazer compreensível o funcionamento de um objeto ou o significado de um fenômeno necessitamos termos ou símbolos que dão uma definição exata, que reflitam as particulares qualidades do objeto com que se trata.

Com respeito à acima delineada estratégia sintrópica de ser do nosso Planeta, assim como com relação à função instrumental da vida dentro deste contexto, na ciência moderna existe, para estes fenômenos serem percebidos, um problema de comensurabilidade entre o ocular usado e o objeto a ser enxergado: o modo de abordagem via análise per sui generi só nos possibilita de seguir processos entrópicos. Isto, no entanto, não é a prova que não existe o inverso também!

A terminologia que usei no gráfico vetorial da vida é uma tentativa de considerar este dito caráter instrumental da vida dentro de um contexto maior do funcionamento sintrópico do macroorganismo Planeta Terra. É uma tentativa também de elucidar a direção em que todos, em conjunto, caminham: não por acaso uma espécie aparece ou desaparece; senão para cumprir uma, a sua particular função no contexto maior do funcionamento do macroorganismo). Ou no caso de sair, por ser inoportuno uma continuação da sua contribuição.

A instrumentabilidade contribuída à vida num contexto maior de uma postulada e delineada estratégia sintrópica de ser do Planeta inteiro faz com que vejamos, conseqüentemente, os processos sucessionais num contexto teleológico.

A terminologia proposta neste texto resultou da tentativa de criar um eficiente instrumentário para fazer compreensível processos ecológicos em todos os lugares no planeta e em todas as etapas da evolução da vida. E além - e sobretudo, uma tentativa de criar as ferramentas que nos possibilitam de planejar e de construir, e em seguida lidar com eles, agroecossistemas, sistemas florestais ou outros ecossistemas antropógenos harmonizados no seu funcionamento com o dos ecossistemas naturais e originais dos seus respectivos lugares com interações sinergéticas com eles. 
Igualmente como os ecossistemas naturais, os nossos ecossistemas antropógenos deveriam ter um balanço positivo de vida e de energia materializada, tanto nos subsistemas das nossas intervenções quanto no macroorganismo Planeta Terra inteiro.

Conseqüentemente será imperativo rever e, em seguida, redefinir - no nosso interesse, para não ser tão logo definitivamente inoportuno uma combinação da nossa presença - a nossa possível função, isso é, passar da achada posição superior excepcional e privilegiada a reencontrar e cumprir a nossa (prevista) função.

\section{Definição dos termos usados:}

Sistema (palavra usada no Gráfico Vetorial, acompanhado da terminologia 'de ótima ocupação' ou 'de abundância'): ciclo completo de inspiração e expiração na sucessão natural (correspondente ao ciclo de vida do indivíduo) que passa por quatro fases de desenvolvimento distintos, culminando toda vez, no fim de cada fase, numa metamorfose (transição/transformação). Para um andamento harmônico nos processos sucessionais durante o ciclo de vida de um sistema são necessárias - com parcial divergência para os colonizadores, de quatro grupos completos de consórcios que, por sua vez, num bioma, chegam primeiro a ser parte, depois, o consórcio dominante, para em seguida serem transformados, na seguinte ordem: 1 . Pioneiros $\rightarrow 2$. Secundários $\rightarrow 3$. Intermediários $\rightarrow 4$. Transicionais (vide Gráfico 2).

Pelas características diferentes (dos sistemas) podemos classificá-los em três grupos, porém que tenham como uma das características parecerem na forma interferente entre os sistemas próximos enquanto qualidade e quantidade de vida consolidada.

Os três grupos de sistemas são:

Colonizadores $\rightarrow$ sistemas de ótima ocupação e $\rightarrow$ sistemas de abundância.

Estes sistemas se diferenciam entre eles quanto:

- quantidade e qualidade de vida consolidada;

- biodiversidade;

- caminho e destino do excedente da energia materializada;

- relação entre $\mathrm{C} / \mathrm{N}$ do conjunto da massa viva das espécies participantes; 
- número (relativo) e tamanho (relativo) de animais necessários para otimizar os processos de vida entre as espécies integradas nos consórcios que formam o sistema.

\section{BIBLIOGRAFIA}

THONNARD, A.A. Compêndio de História da Filosofia. São Paulo: Ed. Herder. Tomo II. 1968. p. $658-661$. 
ANEXO V: Ilustração das fases do desenvolvimento individual e os processos de crescimento e de sucessão dentro de um ciclo maior de inspiração e de expiração (dito sistema), exemplicficado para o ecossistema mata.

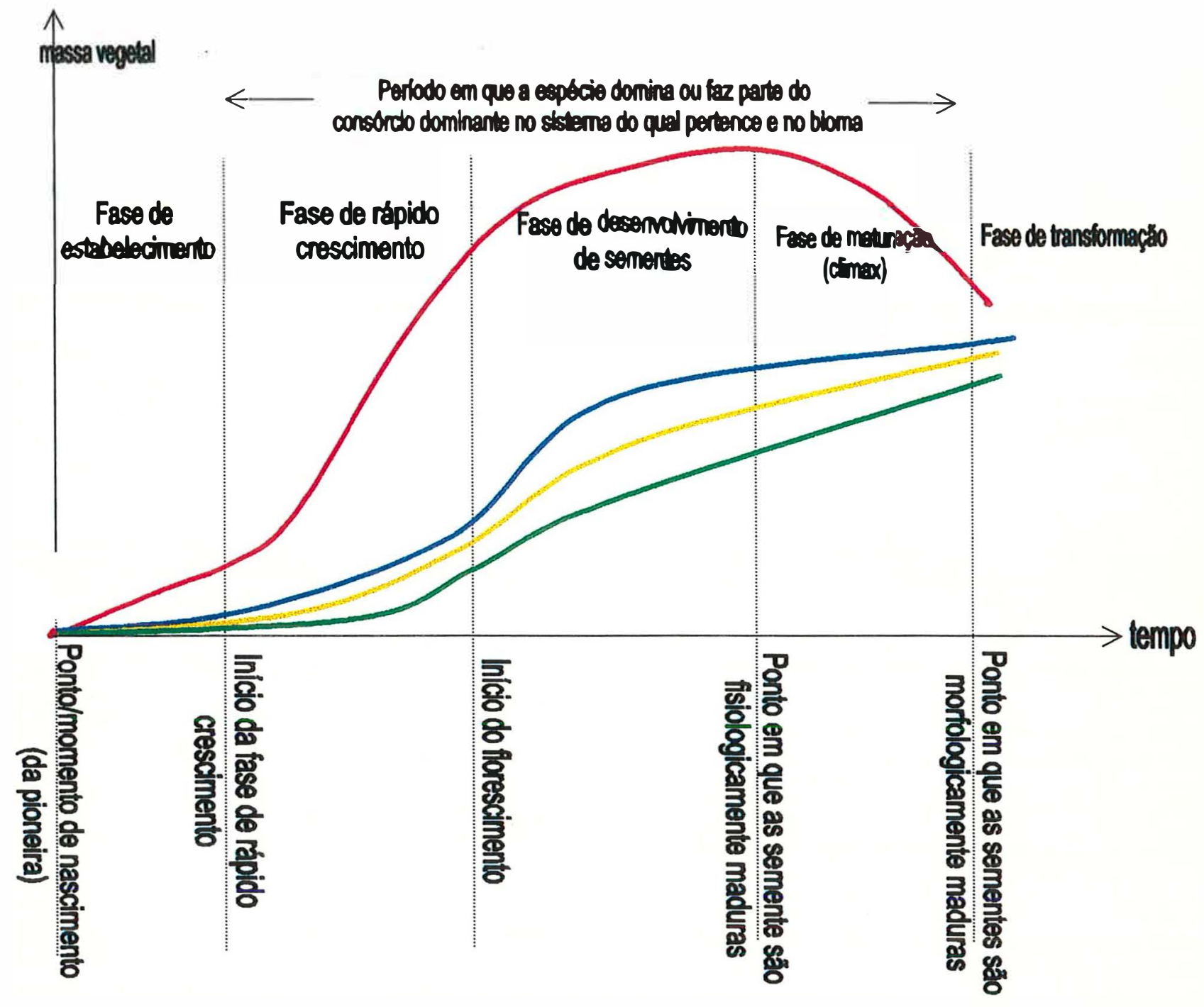

pioneiras

secundárias

$\square$ intermediárias

transicionais 
ANEXO W: Ilustração dos ciclos de vida das pioneiras e secundárias, no processo sucessional, para um ecossistema floresta.

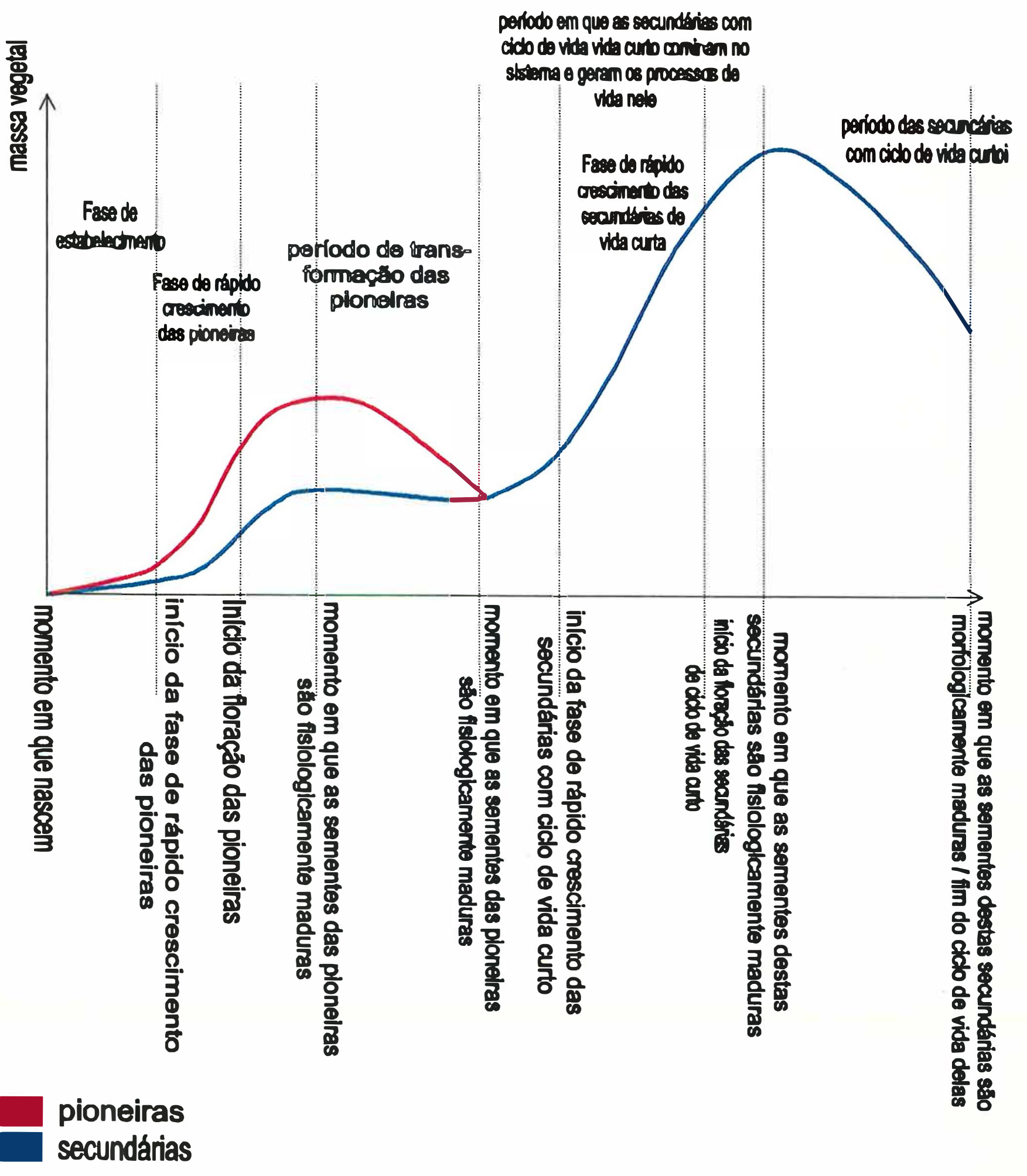




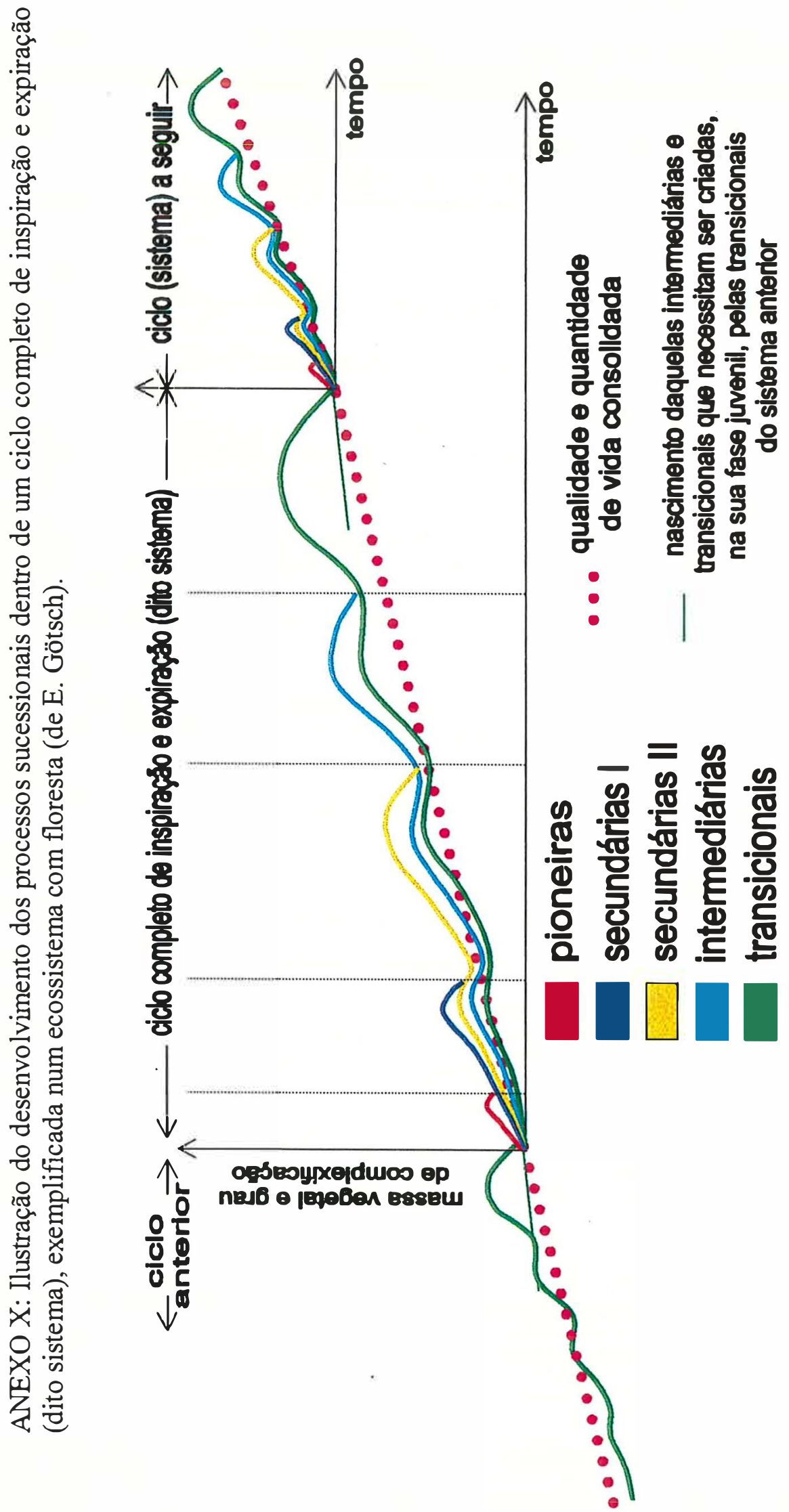

